\title{
Sustainability and sustainable development
}

\section{Magdalena Stefańska Editor}

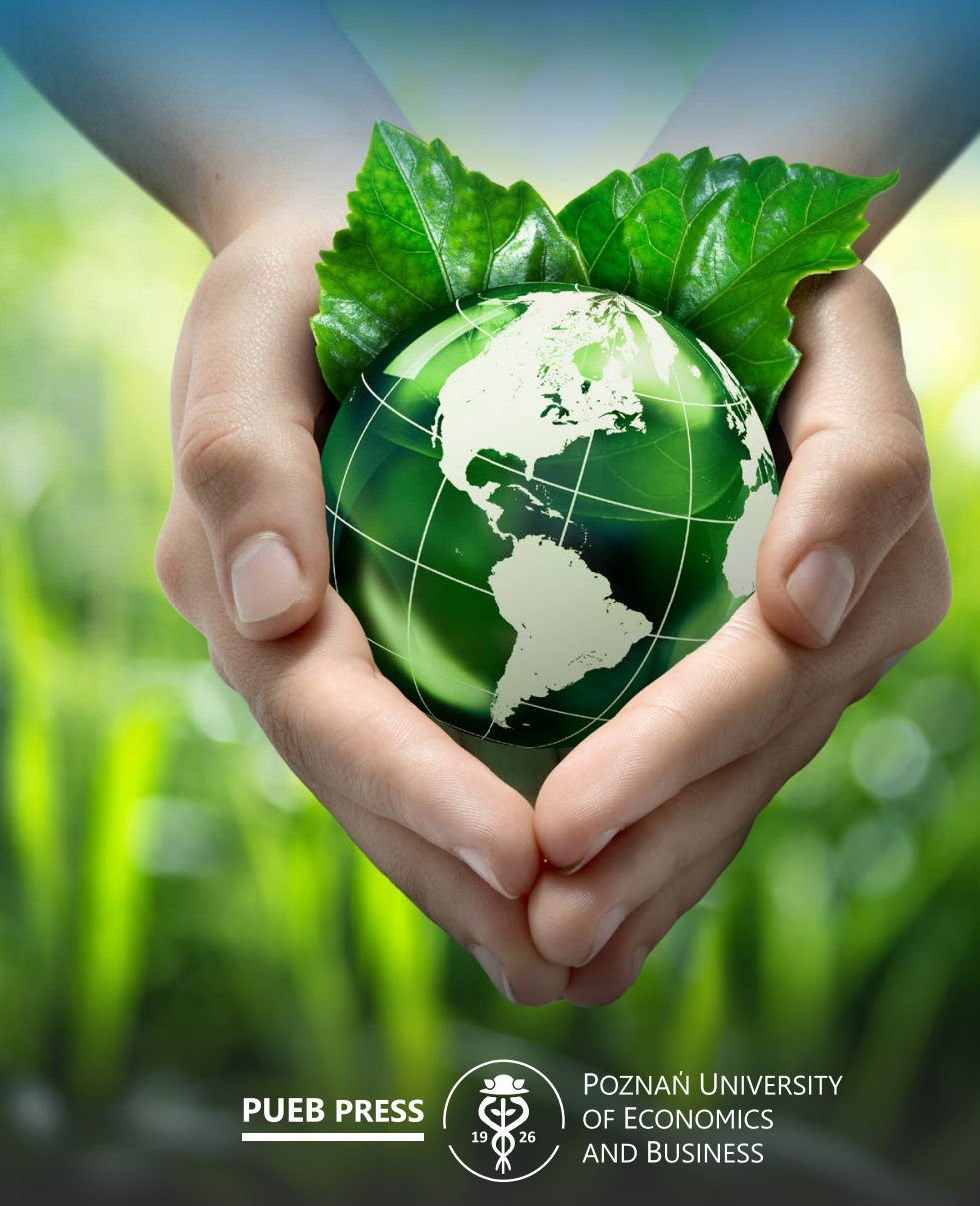





\section{Sustainability and sustainable development}

\section{Magdalena Stefańska Editor}

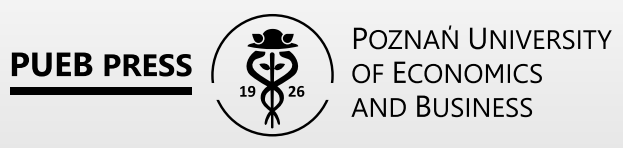

Poznań 2021 


\title{
EDITORIAL BOARD
}

Barbara Borusiak, Szymon Cyfert, Bazyli Czyżewski,

Aleksandra Gaweł (chairwoman), Tadeusz Kowalski, Piotr Lis, Krzysztof Malaga, Marzena Remlein, Eliza Szybowicz (secretary), Daria Wieczorek

\author{
REVIEWER \\ Mia Delić \\ COVER DESIGN \\ Piotr Gołębniak \\ MANAGING EDITOR \\ Grażyna Jeżewska \\ PROOFREADER \\ Katarzyna Smith-Nowak \\ DTP: eMPi ${ }^{2}$ \\ Reginaldo Cammarano
}

Publication financed by Polish National Agency for Academic Exchange Project Central European Network for Sustainable and Innovative Economy, no. PPI/APM/2019/1/00047/U/00001

(C) Copyright by Poznań University of Economics and Business Poznań 2021

eISBN 978-83-8211-074-6

https://doi.org/10.18559/978-83-8211-074-6

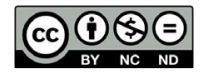

This textbook is available under the Creative Commons 4.0 licenseAttribution-Noncommercial-No Derivative Works

\footnotetext{
POZNAŃ UNIVERSITY OF ECONOMICS AND BUSINESS PRESS

ul. Powstańców Wielkopolskich 16, 61-895 Poznań, Poland phone: +48 618543154,618543155

www.wydawnictwo.ue.poznan.pl, e-mail: wydawnictwo@ue.poznan.pl postal address: al. Niepodległości 10, 61-875 Poznań, Poland
} 


\section{CONTENTS}

\section{PART I \\ SUSTAINABILITY AND SUSTAINABLE DEVELOPMENT- \\ THEORETICAL BACKGROUND}

\section{Jana Gálová, Anna Mravcová}

1. SUSTAINABLE DEVELOPMENT IN CONTEMPORARY WORLDDETERMINANTS

1.1. Globalisation

1.2. Climate changes

1.3. Poverty vs. unlimited consumption

1.4. Limited exhausted access to resources

\section{Barbara Borusiak}

\section{SUSTAINABILITY, SUSTAINABLE DEVELOPMENT AND} CORPORATE SOCIAL RESPONSIBILITY

2.1. The origin and meaning of sustainability and sustainable development as a concept

2.2. From sustainable development to Corporate Social Responsibility

\section{Barbara Borusiak}

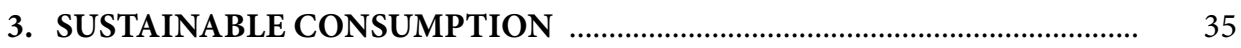

3.1. The essence of sustainable consumption ......................................................... 36

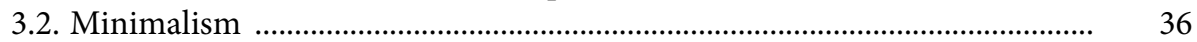

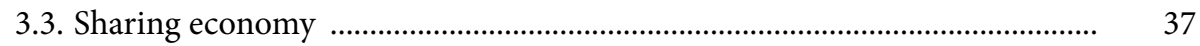

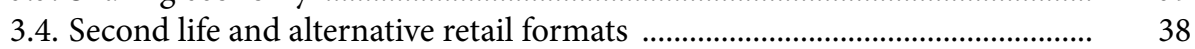


Anna Mravcová, Jana Gálová

4. PRINCIPLES OF THE UNITED NATIONS GLOBAL COMPACT

4.1. Theoretical background

4.2. Principles of the UN Global Compact ............................................................... 46

4.3. UN Global Compact and Sustainable Development Goals ............................ $\quad 49$

Magdalena Stefańska, Blaženka Knežević

5. SUSTAINABLE DEVELOPMENT AND CORPORATE SOCIAL RESPONSIBILITY-ORGANISATIONAL LEVEL

5.1. Theoretical background

5.2. Elements of sustainable development at the corporate level

5.3. Incorporating sustainable development into corporate objectives

5.4. Integrating corporate strategy with social development and Corporate Social Responsibility

5.5. Sustainable development at a functional level of organisations

\section{PART II \\ SUSTAINABLE DEVELOPMENT \\ AND CORPORATE SOCIAL RESPONSIBILITY IN MANAGEMENT}

\section{Blaženka Knežević, Petra Škrobot}

1. SUSTAINABLE DEVELOPMENT IN CORPORATE STRATEGY

1.1. Setting corporate mission and vision in accordance with Sustainable

Development Goals

1.2. Global and local perspectives of sustainable development

1.3. Conflict of Sustainable Development Goals in organisation

\section{Atanaska Reshetkova}

2. SUSTAINABLE DEVELOPMENT IN MARKETING STRATEGY .............. 83

2.1. Sustainability as a source of value for customers

2.2. Social and environmental aspects of sustainable development in marketing strategy

2.3. Sustainability marketing: changes in the marketing mix

3. SUSTAINABLE DEVELOPMENT AND MARKET RESEARCH

3.1. Sustainable development research based on secondary resources

3.2. Sustainable development research based on primary resources

3.3. Sustainable development in market research-ethical aspects 


\section{Magdalena Stefańska}

4. SUSTAINABILITY IN HUMAN RESOURCE MANAGEMENT

4.1. Meaning of sustainability in human resource management

4.2. Sustainability in human resource management-recruitment and selection

4.3. Employer branding and sustainability

4.4. Motivation and sustainability in human resource management

4.5. Remote work and sustainable development

4.6. Reduction of employment in responsible organisations

\section{Marzena Remlein}

\section{SUSTAINABLE DEVELOPMENT IN ACCOUNTING}

5.1. Importance of accounting in the concept of sustainable development .........

5.2. Integrated reporting

\section{Krisztián Kis}

6. SOCIAL RESPONSIBILITY AND QUALITY: ISSUES OF COMPETITIVENESS AND SUSTAINABLE DEVELOPMENT

6.1. Understanding quality and its relation to social responsibility and sustainable development

6.2. Creating quality through innovation to promote competitiveness and sustainable development

\section{Dariusz Nowak}

7. SUSTAINABLE DEVELOPMENT IN PRODUCTION-OPERATIONS MANAGEMENT

7.1. Sustainability in operational management: theoretical background

7.2. Zero-waste concept in operations management

7.3. Lean manufacturing and six-sigma in sustainable development .........

7.4. Circular production

7.5. Life-cycle product design and recycling

7.6. Green and environment-conscious manufacturing

\section{PART III}

SUSTAINABLE DEVELOPMENT IN MANAGEMENT

\section{MARKETING CAMPAIGNS AND SUSTAINABILITY ISSUES}

1.1. Love for local brands

1.2. Sustainable fashion: the case of H\&M 
Iwona Olejnik, Magdalena Stefańska

2. CONSUMPTION AS THE SUBJECT OF MARKET RESEARCH

2.1. Is it possible to conduct consumption research on the basis of garbage? ...

2.2. Consumption of cigarettes as a subject of market research

Natalia Jankowska

3. CORPORATE SOCIAL RESPONSIBILITY TOWARDS EMPLOYEESRABEN GROUP

3.1. Raben Group-presentation of the company

3.2. Tools applied in human resources management by the Raben Group ......... $\quad 188$

Appendices

\section{Gabriel Grabowski}

4. REMOTE WORK AT INTERNATIONAL ENTERPRISES

4.1. Plant relocation

4.2. Hiring a specialist from a different location

4.3. Threat of pandemic

Magdalena Stefańska

\section{PRODUCT LIFE-CYCLE-PROBLEMS OF PRODUCT PLANNED}

OBSOLESCENCE AND FAST FASHION

5.1. Planned product obsolescence-how to overcome the problem?

5.2. Fast fashion - on the way to sustainability or... greenwashing?

PART IV

SUSTAINABILITY AND SUSTAINABLE DEVELOPMENT-SECTORAL PERSPECTIVE

\section{Krisztián Kis}

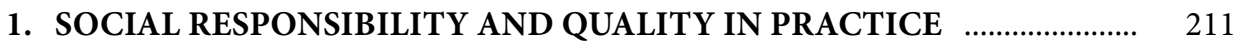

1.1. Sustainable restaurant initiative ......................................................................... 212

1.2. Safe place certification .............................................................................. 214

\section{Agnieszka Chomiuk}

\section{SUSTAINABLE DEVELOPMENT IN NON-GOVERNMENTAL} ORGANISATION SECTOR

2.1. From basic human rights to economic and social profit: solving the problem of homelessness based on the "Housing First" method

2.2. Social capital in building a safe future for people with intellectual disabilities

2.3. Profit plus or about the social and economic value of social entrepreneurship on a concrete example 


\section{Blaženka Knežević}

\section{SOCIAL SUPERMARKETS AS A SOLUTION TO FOOD WASTE} AND ISSUES OF POVERTY

3.1. Food waste as a problem in food supply chains

3.2. Reduction of poverty by implementing social supermarkets as new players in food supply chains

\section{Magdalena Stefańska, Gabriel Grabowski}

4. WHY DO CONSUMERS FAIL TO FOLLOW WASTE SEGREGATION RULES? WHAT WOULD MOTIVATE THEM TO OBEY THE REGULATIONS?

4.1. Description of the issue

4.2. Segregation versus waste collection costs

\section{Gabriel Grabowski}

\section{CIRCULAR ECONOMY IN THE WASTE MANAGEMENT SECTOR}

5.1. Problem of communal waste segregation

5.2. Corporate Social Responsibility challenges and recycling

5.3. Education and convenient selective waste collection

\section{Gabriel Grabowski}

6. SUSTAINABILITY IN RENEWABLE ENERGY BUSINESSES

6.1. Introduction: green energy

6.2. Thermal solar installation at educational institutions

6.3. Development of photovoltaic installation

\section{Magdalena Stefańska, Iwona Olejnik}

7. LIGHTS AND SHADOWS OF AIRBNB AND ALL-INCLUSIVE VACATIONS: HOW TO MAKE THEM MORE SUSTAINABLE?TOURIST SECTOR

7.1. Sustainability in the tourism sector

7.2. All-inclusive as a/an (un)sustainable model of business

7.3. Airbnb as an example of sharing economy 



\section{PREFACE}

The aim of this e-book is to present the most important aspects related to Sustainable Development, Sustainability and Corporate Social Responsibility. They are discussed from macro- and micro-perspectives. Theory and case studies discussed in the e-book can be useful for readers who are interested both in the theoretical foundations of these concepts and practical examples of companies from Central and Eastern European countries that have implemented them in their everyday activities, further being translating into corporate and functional strategies.

As a result, the book consists of 4 parts. The first is theoretical in its foundations. It is dedicated to explaining the following key terms: Sustainable Development (SD), Sustainability (S) and Corporate Social Responsibility (CSR). The genesis of these related phenomena: sustainability and sustainable development concepts, as well as the range of definitions, are elaborated in order to suggest a definition that could be applied in the whole e-book. The authors also describe various determinants of sustainable development in the contemporary world, including those most important, such as globalisation, climate change, poverty, unlimited consumption as well as limited exhausted access to resources-all with regard to Sustainable Development Goals. They give the reader essential resources covering the topic from various viewpoints and a starting point for discussion about sustainability. Furthermore, the Corporate Social Responsibility concept, which is nowadays recognised as the process through which business contributes to sustainable development implementation, is discussed. How Sustainable Development and Corporate Social Responsibility are incorporated in strategies of organisations and influence corporate strategy on corporate and functional areas of organisation is demonstrated in the final chapter of the first part of the e-book.

The next part of the e-book helps readers to understand SD and CSR concepts in corporate strategy-strategic management and functional areas-marketing, human resources, marketing research, accounting and operational management. The authors explain motives as to why companies have to consider local and global perspectives when setting SD objectives, and the existence of conflicts in SD goals. When marketing is concerned, managers must consider that environmental and social awareness of all stakeholders is constantly increasing. This makes consumers, i.e. look for and choose eco-friendly products, avoiding excessive waste, while 
reusing products and materials. Shifting to a more sustainability-oriented approach to the market is an opportunity for growth, as it is a source of value for customers. Marketers are always looking for new ways to satisfy their targeted customers by adding value to their offers. How different aspects of sustainability can be incorporated into a marketing strategy to create, communicate and distribute value to customers is widely discussed.

The issue of sustainable development is also the subject of market researchamong companies manufacturing products and providing services, institutions dealing with environmental or consumer protection, scientists and students conducting various research projects related, for example, to sustainable, responsible consumption and production patterns, ensuring healthy lives and promoting wellbeing of all age groups, etc. How to use secondary data for analysis and how to prepare, conduct, analyse and interpret the results of primary research in the area of sustainable development (SD) is presented in detail in the following chapter of this part. The concept of sustainability is also referred to the basic functions of human resources-recruitment, motivation, assessment and control. They should embrace sustainability not just for organisational effectiveness and long-term economic benefits, but also for ethical reasons, however-owing to sustainable human resource management, the awareness and behaviour of the whole organisation may strongly express sustainable goals in planning and implementing the whole corporate strategy. The term 'sustainable practices' in SHRM (Sustainable Human Resource Management) is often congruent with CSR.

The growing importance of the sustainable development idea, as well as the concept of Corporate Social Responsibility, also gave rise to the need for accounting systems to develop solutions enabling the provision of information on the methods and results of implementing these concepts among entities operating on the market. The interest in accounting within the area of sustainable development has contributed to the creation of vocabulary related to measurement, calculation, disclosure, reporting and verification of information about the activities of units for sustainable development.

In that part of the e-book, production-operation is additionally analysed within the context of sustainable development. Production requires the involvement of various resource types, such as: raw materials, materials, machines, capital, information, energy, human factor and others, which are used in production processes. As a result many problems arise in operational activity: waste of resources or their wasteful use, mismanagement, excessive energy consumption, environmental pollution, exploitation of human potential, etc. These problems are reflected both in the growing costs of the company's activities and in climate change. The purpose of implementing new solutions of production is to improve labour mobility, optimise the use of raw materials and resources, induce cost reduction, increase efficiency, productivity, etc. Such methods as the zero-waste concept, lean-manufacturing, six-sigma, circular 
production, life-cycle product design and recycling as well as green and environmentconscious production, are presented. Taking the impact of operating activities on the environment into account, the purpose of the subsequent chapter is to discuss how to quality should be understood, and are the relationships between the involved issues are. In this chapter, it is argued that quality, Corporate Social Responsibility, innovation, competitiveness and sustainable development are interrelated concepts.

The next 2 parts include examples of companies from Central and Eastern European countries that have applied SD goals in their strategies. The main objective of these sections is both to build awareness of readers as to what companies do and what kind of innovative solutions can be implemented to carry out those goals. A further purpose of that the mentioned parts is to open and develop critical discussion on environmental and society-related problems existing in contemporary societies and businesses, which negatively influence the future of present and following generations. Some of the business models are extremely unfriendly and against SD—for instance, purposeful product obsolescence or fast fashion. It seems necessary to underline the side- or main, negative-effects of unlimited consumption and organisation policies to stimulate demand by shortening product life-cycle. Other business models presented in the e-book-such as all-inclusive or Airbnb-are also questionable as they create opportunities for local markets but, at the same time, cause environmental or societal problems.

Other examples presented in this part refer to the $3 \mathrm{R}$ concept-reduce, reuse, recycle, especially the role of the retail sector developing new type of supermarkets-social supermarkets.

Also, based on 3 examples, the problem of waste is discussed-from the consumer and organisation perspectives. Finally, information of renewable energy is also presented-from the perspective of the final consumer.

We understand that these are only part of the issues that should be addressed in this e-book. However, we hope that the content presented to the readers will provoke reflection and contribute to active participation in the implementation of SD goals-at organisations and in private life.

\section{Acknowledgements}

This e-book was created thanks to the involvement of many people from several universities and various practitioners. The work on the preparation was carried out by staff and Ph.D. students from several universities: University of Zagreb, Slovak University of Agriculture in Nitra, D.A. Tsenov Academy of Economics, University of Szeged as well as the Poznan University of Economics and Business.

I would like to sincerely thank all the authors for their commitment and help in preparing both the theoretical as well as practical parts of this work. Jana Gálová and Anna Mravcová prepared texts on the importance of the sustainable development concept and the Principles of UN Global Compact, Barbara Borusiak undertook 
the challenge of explaining the concepts of sustainable development, sustainability and Corporate Social Responsibility, Blaženka Knežević and I focused on locating the concept of SD and CSR within the strategic management of enterprises, showing how these ideas penetrate sectors, also at strategic and operational levels of the organisation and how they work in various functional areas. The authors: Agnieszka Chomiuk, Gabriel Grabowski, Natalia Jankowska, Krisztián Kis, Dariusz Nowak, Iwona Olejnik, Atanaska Reshetkova, Marzena Remlein and Petra Škrobot prepared the following parts of the publication, in which they explored the problem of $\mathrm{SD}$ regarding individual functional areas of enterprises and prepared case studies. They show what kind of problems organisations that wish to implement the ideas of sustainable development in their daily tasks face in practice. Thank you all.

This publication would not have been written if not for the international project, coordinated by Barbara Borusiak. It is thanks to her efforts and commitment that cooperation between universities from Croatia, the Czech Republic, Bulgaria, the Ukraine, Slovakia, Hungary and Poland has been established and strengthened. The project titled Central European Network for Sustainable and Innovative Economy (CENETSIE) is financed by NAWA funds intended for the development of international cooperation (PPI/APM/2019/1/00047/U/00001). The project was implemented in the years 2020-2022.

On behalf of the entire team of authors, I would like to thank the reviewer Prof. Mia Delić for her valuable comments.

We would also like to thank the employees of the Publishing House of Poznan University of Economics and Business for its help in publishing the e-book.

Furthermore, we owe much appreciation for preparing the cover design.

We have great optimism that our publication will contribute to a better understanding of the sustainable development concept, sustainability and Corporate Social Responsibility, and that discussions on the problems faced by industries or individual entities will encourage all those interested in the issues to pose further questions and take up challenges posed by modern business and societies around the world, in social, economic and environmental areas. The publication was created at a difficult time for everyone, when the world was hit by the COVID-19 pandemic. This factor strongly influenced our understanding of the issues raised, the form of cooperation and the problems faced by individual countries.

We hope, as a team of authors, that thanks to international cooperation on the book, a series of joint research, organisational and teaching works will be continued. 


\section{PART 1.}

\section{SUSTAINABILITY}

AND SUSTAINABLE

DEVELOPMENT-THEORETICAL BACKGROUND 



\title{
1.
}

\section{SUSTAINABLE DEVELOPMENT IN CONTEMPORARY WORLD- DETERMINANTS}

\section{Jana Gálová}

Faculty of Economics and Management, Slovak University of Agriculture in Nitra

\section{Anna Mravcová}

Faculty of Economics and Management, Slovak University of Agriculture in Nitra

\begin{abstract}
The aim of this chapter is to describe various determinants of sustainable development in the contemporary world, including those most important, such as globalisation, climate change, poverty versus unlimited consumption as well as limited exhausted access to resources-with regard to the goals of sustainable development. The other objective is to give the reader essential resources covering the topic from various viewpoints and a starting point for discussions about sustainability.
\end{abstract}

Keywords: climate change, globalisation, poverty, resources, sustainable development, unlimited consumption. 


\subsection{Globalisation}

The world of business has undergone significant changes in recent years. Kotabe and Helsen (2017, p. v-vi) explain 4 more than extraordinary changes. First of all, the landscape of the global economy has changed drastically, the main reasons being the global financial crisis and the ensuing lackluster global market environment. Secondly, the growth of information technology tools, including the Internet and e-commerce, has had significant influence on the way we do business internationally. Thirdly, there is always a desire to be different when there are economic and political forces of convergence (often referred to as globalisation). From the supply-side, globalisation has brought us more products from all corners of the world. However, from the demand-side (marketing-perspective), customers have a much broader set of goods and services to choose from. Fourth of all, if not last, we have become increasingly aware of the various consequences of corporate action, from environmental pollution to global warming with rising sea levels around the world, and from food safety to unsafe work environments around the world (Gálová \& Horská, 2013).

Many other authors (e.g. Beck, 2004; Ghemawat, 2007; Goldin and Reinert, 2007; Hennis, 2005; Hollensen, 2017; Paul \& Kapoor, 2008; Svatoš, Smutka, \& Rosochatecká, 2011) deal with the topic of globalisation and internationalisation.

Globalisation, in comparison to internationalisation, is much younger as a concept. At a macroeconomic level, globalisation is treated as the phenomenon of increasing globally diverse ties between economies, following the increasing size and diversity of transactions regarding goods, services and international financial flows, as well as technology transfers as a result (Daszkiewicz \& Wach, 2012 , p. 8). Globalisation can be seen as a summary of changes from 3 global aspects: culture, economics and environment. It can be described as deepening the relationship and broadening interdependence among people from different parts of the world, and especially among different countries (Daniels, Radebaugh, \& Sullivan, 2017). Globalisation reflects the trend of firms buying, selling and distributing products and services in most countries and regions of the world (Hollensen, 2017).

Thanks to market globalisation, we have become more receptive to new things, while we also have a much wider, more divergent "choice set" of goods and services to choose from, which shape our own individual preferences and lifestyles (Kotabe \& Helsen, 2017, p. 11). Nonetheless, from a marketing point of view, it is becoming more difficult-not easier-to pinpoint consumer preferences in any local market around the world, the more globalised the markets become (Nowak \& Kochkova, 2011).

There are 4 major categories of potential globalisation benefits: cost reduction, improved quality of products and programmes, enhanced customer preference, and 
increased competitive advantage on a global basis (Kotabe \& Helsen, 2017). Sethna (2008) reviews 2 books by the authors Pankaj Ghemawat and Thomas Friedman, offering differing opinions about whether the world is flat-in terms of influences which have flattened (or levelled) international business conditions. Friedman (2007) believes that technological innovation has removed many of the barriers that limited lots of businesses to a local playing field. But Ghemawat (2007) argues that the differences between countries are still significant. The right business strategy is neither local customisation nor global standardisation, or the one that proposes a compromise between those 2 extremes. Instead, he believes that companies must compete in an integrated way. These 2 publications are recommended readings for those who are interested in learning more about rather opposing viewpoints on globalisation in business.

For 3 main reasons, national markets continue to exist while being part and giving way to the extending global market. The first explanation is innovation of technologies, which enabled declining prices for transportation and telecommunication services substantially; therefore, companies have the possibility to minimise production costs by moving some of these activities overseas. Secondly, globalisation is supported by international trade liberalisation, where the reduction of tariffs contributes to the growth of trade and investment. Thirdly, the continuous change and development provided additional incentives for global integration. Certainly, there are other various reasons for going global, such as avoiding dependence on the domestic market and economies of scale (Czinkota \& Ronkainen, 2012, p. 4).

\subsection{Climate changes}

In 2010, the World Business Council for Sustainable Development (WBCSD) launched Vision 2050, a landmark study that laid out a pathway to a world in which 9 billion people will able to live well within the boundaries of the planet by mid-century (WBCSD, 2020).

Created with 29 WBCSD members from 14 industries, and including insights from more than 200 companies and external stakeholders in some 20 countries, it was declared that doing business as usual was not sustainable (WBCSD, 2010).

Although many of the concepts at the core of Vision 2050 have largely outstood the test of time, inevitably, a number of topics have either increased in importance or emerged as critical new areas within the sustainable development landscape and beyond. Furthermore, the world in which businesses are operating continues to change: social tension and environmental impact are on the rise, fundamental questions are being asked about the role of business, and the economy as a whole, while the COVID-19 pandemic has brought a level of global disruption unprecedented in modern times-hence the WBCSD's Vision 2050 Refresh project was introduced. 


\section{SUSTAINABLE G
DEVELOPMENT}

Figure 1. Sustainable Development Goals

Source: (UN 2020b).

The Sustainable Development Goals (Figure 1) are a universal call for action by the United Nations (2020c) to end poverty, protect the planet and improve the lives and prospects of everyone and everywhere. The 17 Goals (Figure 2) were adopted by all UN Member States in 2015 as part of the 2030 Agenda for Sustainable Development, which set out a 15-year plan to achieve these Goals.

Within the aforementioned 17 Goals, Goal 13 aims at tackling climate change and calls for urgent action to combat climate change and its effects. It is intrinsically linked to all the other 16 Goals. To address climate change, countries adopted the Paris Agreement to limit global temperature rises to well below 2 degrees Celsius (UN, 2020a).

The statistics are alarming. 2019 was the second warmest year on record and the end of the warmest decade (2010-2019) ever recorded (UN News, 2020b). Carbon dioxide levels and other greenhouse gases in the atmosphere also rose to new records in 2019 (UN News, 2020a). Although these emissions are projected to drop by about $6 \%$ in 2020 due to travel bans and economic slowdowns resulting from the COVID-19 pandemic, this is only temporary. Once the global economy begins to recover from the pandemic, emissions are expected to return to higher levels.

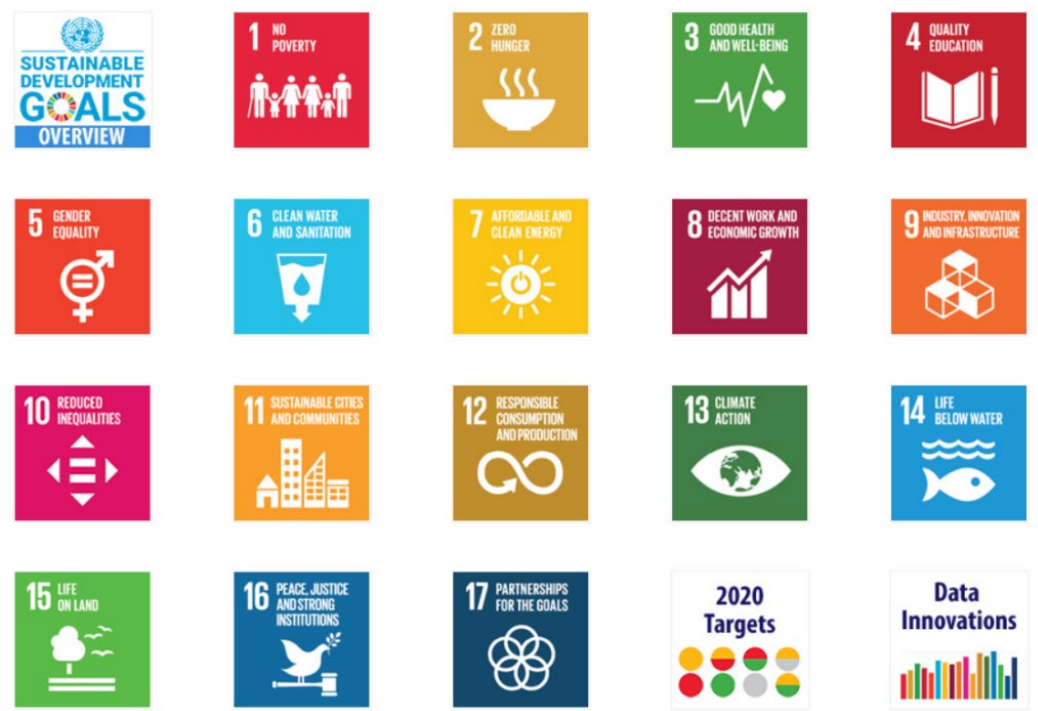

Figure 2. Sustainable Development Goals-overview

Source: (UN 2020d). 
The Paris Agreement (UNFCCC, 2020) adopted in 2015 is aimed at strengthening the global response to the threat of climate change by keeping a global temperature rise in this century well below 2 degrees Celsius above pre-industrial levels. The agreement is also aimed to strengthen the ability of countries in dealing with the impact of climate change, through appropriate financial flows, a new technology framework and an enhanced capacity building framework.

\subsection{Poverty vs. unlimited consumption}

The World Bank (2020d) publishes the revised classification of world economies annually, based on the income classifications by GNI per capita shown in Table 1.

Economies are currently divided into 4 income groupings: low, lower-middle, upper-middle and high (World Bank, 2020a). Income is measured using gross national income (GNI) per capita, in U.S. dollars, converted from local currency using the World Bank Atlas method. Estimates of GNI are obtained from economists in World Bank country units; and the size of the population is estimated by World Bank demographers from a variety of sources, including the UN's biennial World Population Prospects.

Countries are immediately reassigned on July $1^{\text {st }}$ each year, based on the estimate of their GNI per capita for the previous calendar year. Income groupings remain fixed for the entire fiscal year (i.e., until July $1^{\text {st }}$ of the following year), even if GNI per capita estimates are revised in the meantime.

Table 1. World Bank country and lending groups based on GNI/capita, calculated using the World Bank Atlas method (current \$US)*

\section{THE WORLD BANK Working for a World Free of Poverty}

\begin{tabular}{|l|c|c|c|c|}
\hline Economy groups & as of $1^{\text {st }}$ July 2020 & as of $1^{\text {st }}$ July 2019 & as of $1^{\text {st }}$ July 2018 & as of $1^{\text {st }}$ July 2017 \\
\hline Low income & $<1.035$ & $<1.025$ & $<995$ & $<1.005$ \\
\hline Lower middle-income & $1.036-4.045$ & $1.026-3.995$ & $996-3.895$ & $1.006-3.955$ \\
\hline Upper middle-income & $4.046-12.535$ & $3.996-12.375$ & $3.896-12.055$ & $3.956-12.235$ \\
\hline High income & $>12.536$ & $>12.375$ & $>12.055$ & $>12.235$ \\
\hline
\end{tabular}

Source: Authors' own analysis based on data from the World Bank (2020d).

The World Bank (2020b) states that global extreme poverty is expected to rise in 2020 for the first time in over 20 years as the disruption of the COVID-19 pandemic compounds the forces of conflict and climate change, which were already slowing poverty reduction progress. The global extreme poverty rate fell to 9.2 percent in 2017, which is equivalent to 689 million people living on less than $\$ 1.90$ a day. But 
many people who had barely escaped extreme poverty could be forced back into it by the convergence of COVID-19, conflict, and climate change. By most estimates for 2020, incorporating the effects of the COVID-19 pandemic it is projected that an additional 88 million to 115 million people will be pushed into extreme poverty, bringing the total to between 703 and 729 million.

Khan (2008) reports that poverty, environment and growth are in the centre of interest not only for politicians, but also academics and other scientific researchers. Erokhin and Ivolga (2012) claim that international trade can bring significant benefits to countries. It provides a scope for enormous and sustainable gains in economic growth and poverty reduction that is especially significant for developing countries.

Broussard and Joseph (2009) recognise 2 common poverty measures: absolute and relative. The first one, absolute poverty, refers to the minimum amount of money needed to meet basic human needs (food, shelter, clothing), while relative poverty is based on comparison to other members of the society where people live-where household income is a certain percentage below median incomes.

In January 2002, Prahalad and Hart urged leaders to imagine the world's 4 billion poorest people as potential consumers-and described precisely how they could engage them profitably (Prahalad \& Hart, 2002). This challenged many longheld assumptions about the role of both government and business in addressing poverty. The article was followed by the best-selling 2004 book "The Fortune at the Bottom of the Pyramid". In 2019, Deepa Prahalad updated a portion of the argument in strategy + business (Prahalad, 2019). She presents some interesting statistics as well. In 2017, there were fewer people at the bottom of the pyramid (3.5 billion, compared to 4 billion in 2002). Income tiers had also risen so significantly by 2017 that it is now difficult to directly compare them. By 2017, there was a new concentration of wealth at the top.

The Credit Suisse Global Wealth Report (Credit Suisse Research Institute, 2020) for 2020 shows that the bottom $90 \%$ of countries accounts for $19 \%$ of global wealth, compared to $11 \%$ in the year 2000. In the same report, it has been reported that household wealth is very unevenly distributed-geographical imbalance is evident in the fact that at the end of 2019, North America and Europe accounted for 55\% of total global wealth, but only $17 \%$ of the world adult population. In contrast, the population share was thrice times the wealth share in Latin America, 4 times that in India, and nearly 10 times the wealth share in Africa.

Based on data from Forbes and the annual Credit Suisse Global Wealth databook, Oxfam (Hope, 2018) reports that some 82\% of the money generated in 2017 went to the richest $1 \%$ of the global population, while the poorest half saw no increase at all. Furthermore, with regard to this report, Prahalad (2019) highlights that 42 individuals now possess the same cumulative wealth as the bottom 3.6 billion people on the planet. 
The World Poverty Clock by the World Data Lab (2020) provides real-time poverty estimates up to 2030 for nearly every country in the world. It monitors progress against Ending Extreme Poverty, which is the UN's first Sustainable Development Goal (SDG). The escape rate allows to calculate the current rate of poverty reduction in the world. The methodology for this tool has been peer-reviewed in the academic community and published on the Nature website (in Cuaresma et al., 2018). It shows that in India, approximately 18 people per minute overcome extreme poverty, in Brazil the number totals 66, while in most African countries the escape rate is negative-poverty is rising.

The World Economic Forum (WEF, 2019) report points out that in developing and emerging economies, growth has been accompanied by a significant increase in inequality-despite pulling millions out of poverty and reducing the gap with advanced economies. From business and marketing perspectives, apart from the traditional marketing concept of the 4Ps-Product, Price, Place, Promotion-2 of the most prominent alternative paradigms existing in literature on marketing is that of the 4Cs-Customer value, Customer costs, Customer convenience and Customer communication (Kotler, 2009), and the 4As-Awareness, Availability, Affordability and Acceptability. This concept of the 4As is more tailored to rural consumers, and applicable to the least developed countries (Hollis, 2010). Concerns about the framework and responses to them as well as the concept itself is further explained by several authors (e.g. Balram \& Ghuman, 2010; Choudhary, 2012; Dodd, 2015; Sheth \& Sisodia, 2012).

\subsection{Limited exhausted access to resources}

Within the aforementioned 17 Sustainable Development Goals by the United Nations, Goal 12 directs attention towards ensuring sustainable consumption and production patterns since these rest on the use of the natural environment and resources in a way that continues to have destructive impact on the planet.

Each year, an estimated $1 / 3$ of all food produced-equivalent to 1.3 billion tons worth around $\$ 1$ trillion-ends up rotting in the bins of consumers and retailers, or spoiling due to poor transportation and harvesting practices (FAO, 2020; UNEP, 2020).

If the global population reaches 9.7 billion by 2050 (UN, 2019), the equivalent of almost 3 planets could be required to provide the natural resources needed to sustain current lifestyles.

According to the WWF (2020), some 1.1 billion people worldwide lack access to water, and a total of 2.7 billion find water scarce for at least 1 month of the year. Inadequate sanitation is also a problem for 2.4 billion people-they are exposed to diseases, such as cholera or typhoid fever, and other water-borne illnesses. 
These were only a few examples, more information can be found about facts and figures, data and statistics with regard to this topic (including water, energy and food resources) in the publications of the $\mathrm{UN}$ and the UN environment programme.

The COVID-19 pandemic offers countries an opportunity to build recovery plans that will reverse current trends and change our consumption as well as production patterns towards a more sustainable future.

\section{Questions / tasks}

1. Define globalisation.

2. Discuss the advantages and disadvantages, strengths and weaknesses of the globalisation.

3. Read about WBCSD's Vision 2050 Refresh.

4. Learn more on how to Take Action for the Sustainable Development Goals.

5. Take a look at the overview of the 17 goals from the Sustainable Development Goals Report 2020.

6. Discuss the Paris Agreement.

7. Learn more about the World Bank Atlas method and the historical classifications by income.

8. Take the World Bank's poverty quiz and see How much you know about global poverty.

9. Recommended reading includes information on absolute and relative poverty measurements: Poverty and shared prosperity 2020: Reversals of fortune by the World Bank (2020c).

10. Read the following articles: Prahalad, D., \& Hart, S. L. (2002). The fortune at the bottom of the pyramid and Prahalad, D. (2019). The new fortune at the bottom of the pyramid. At that time, the thinking of Prahalad and Hart had been rejected for 4 years by scholarly journals. What do you think about their original, simple but radical idea?

11. The COVID-19 pandemic has triggered the worst global economic crisis since World War 2 and affected human life in countless ways. Learn more from the interim edition of the Global Wealth Report 2020 in which the impact of the outbreak on wealth and wealth distribution are examined.

12. Take a look at the World Poverty Clock map.

13. Learn more about the topic from the Global Competitiveness Report by the World Economic Forum.

14. Look at the Sustainable Development Goals infographic: No poverty.

15. Read about the Vision towards a responsible future of consumption: Collaborative action framework for consumer industries by the World Economic Forum (WEF). 


\section{References}

Balram, D., \& Ghuman, K. (2010). Rural marketing: Concepts and practices. New Delhi: Tata Mc Graw-Hill Education.

Beck, U. (2004). Čo je globalizácia? Bratislava: Vydavatel'stvo Spolku slovenských spisovatelov.

Broussard, C. A., \& Joseph, A. L. C. (2009). Introduction-the poverty context. In C. A. Broussard, \& A. L. C. Joseph (Eds.), Family poverty in diverse contexts (pp. 1-8). New York: Routledge.

Choudhary, V. (2012). Marketing mix from 4P's to 4A's. Retrieved September, 2020 from http://www. mbaskool.com/business-articles/marketing/5455-marketing-mix-from-4ps-to-4as.html

Credit Suisse Research Institute (2020). The global wealth report 2020. Retrieved September, 2020 from https://www.credit-suisse.com/about-us/en/reports-research/global-wealth-report.html

Cuaresma, J. C., Fengler, W., Kharas, H., Bekhtiar, K., Brottrager, M., \& Hofer, M. (2018). Will the Sustainable Development Goals be fulfilled? Assessing present and future global poverty. Palgrave Communications, 4, 29(2018). https://doi.org/10.1057/s41599-018-0083-y

Czinkota, M. R., \& Ronkainen, I. A. (2012). International marketing. Mason: South-Western.

Daniels, J., Radebaugh, L., \& Sullivan, D. (2017). International business: Environments \& operations. New York: Pearson.

Daszkiewicz, N., \& Wach, K. (2012). Internationalization of SMEs: Context, models and implementation. Gdansk: Gdansk University of Technology.

Dodd, G. D. (2015). For effective marketing, you need both the 4A's and the 4P's. Retrieved September, 2020 from http://b2bmarketingdirections.blogspot.sk/2015/02/for-effective-marketing-you-need-both.html

Erokhin, V., \& Ivolga, A. (2012). International trade with agricultural products: influence of market globalization and integration. In E. Horská et al. (Eds.), Food sciences \& business studies: Global-regional-local approach. Nitra: SUA.

FAO-Food and Agriculture Organisation of the United Nations. (2020). Food loss and food waste. Retrieved September, 2020 from http://www.fao.org/policy-support/policy-themes/food-loss-food-waste/en/

Friedman, T. L. (2007). The world is flat 3.0: A brief history of the twenty-first century. New York: Picador. Gálová, J., \& Horská, E. (2013). Sustainability in business: Global challenges in international business. In E. Horská, \& T. I. Yespolov (Eds.), Sustainability in business and society: Global challenges-local solutions (pp. 111-132). Kraków: Wydawnictwo Episteme.

Ghemawat, P. (2007). Redefining global strategy: Crossing borders in a world where differences still matter. Boston: Harvard Business School Press.

Goldin, I., \& Reinert, K. A. (2007). Globalization for development. Washington: World Bank Publications.

Hennis, M. (2005). Globalization and European integration: The changing role offarmers in the common agricultural policy. Lanham: Rowman \& Littlefield.

Hollensen, S. (2017). Global marketing. Harlow: Pearson Education.

Hollis, N. (2010). The global brand: How to create and develop lasting brand value in the world market. New York: Palgrave Macmillan.

Hope, K. (2018). 'World's richest 1\% get $82 \%$ of the wealth', says Oxfam. Retrieved September, 2020 from https://www.bbc.com/news/business- 42745853

Khan, H. (2008). Poverty, environment and economic growth, exploring the links among three complex issues with specific focus on the Pakistans case. Environmental Development Sustainability, 10(6), 913-929.

Kotabe, M., \& Helsen, K. (2017). Global marketing management. Hoboken: Wiley.

Kotler, P. (2009). Marketing management. Harlow: Pearson Education. 
Nowak, J., \& Kochkova, O. (2011). Income, culture, and household consumption expenditure patterns in the European Union: Convergence or divergence? Journal of International Consumer Marketing, 23(3/4), 260-275.

Paul, J., \& Kapoor, R. (2008). International marketing: Text and cases. New Delhi: Tata McGraw-Hill. Prahalad, D. (2019). The new fortune at the bottom of the pyramid. Consumer \& Retail, 94, Spring 2019. Retrieved September, 2020 from https://www.strategy-business.com/article/The-New-Fortune-at-the-Bottom-of-the-Pyramid

Prahalad, C. K., \& Hart, S. L. (2002). The fortune at the bottom of the pyramid. Strategy + Business, 26, First quarter 2002. Retrieved September, 2020 from http://www.cs.berkeley.edu/ brewer/ ict 4 b/Fortune-BoP.pdf

Sethna, B. N. (2008). Ghemawat v. Friedman: Is the world flat?. Retrieved September, 2020 from https://www.researchgate.net/profile/Beheruz_Sethna/publication/228467905_Ghemawat_v_ Friedman_Is_the_World_Flat/links/56c622e508ae408dfe4d2883/Ghemawat-v-Friedman-Is-the-World-Flat.pdf

Sheth, J. \& Sisodia R. (2012). The 4A'S of marketing: Creating value for customers, company and society. Abingdon, Oxon: Routledge.

Svatoš, M., Smutka, L., \& Rosochatecká, E. (2011). Globalizační procesy v zemědělství a role EU v rámci globálního trhu. Praha: Powerprint.

UN-United Nations (2020a). Goal 13: Take urgent action to combat climate change and its impacts. Retrieved September, 2020 from https://www.un.org/sustainabledevelopment/climate-change/

UN-United Nations (2020b). Sustainable Development Goals. Retrieved September, 2020 from https:// www.un.org/sustainabledevelopment/wp-content/uploads/2020/05/SDG_website_E_v2_100px. png

UN-United Nations (2020c). The sustainable development agenda-17 goals for people, for planet. Retrieved September, 2020 from https://www.un.org/sustainabledevelopment/development-agenda/

UN-United Nations (2020d). The Sustainable Development Goals report 2020. Retrieved September, 2020 from https://unstats.un.org/sdgs/report/2020/The-Sustainable-Development-Goals-Report-2020.pdf

UN-United Nations, Department of Economic and Social Affairs, Population Division (2019). World population prospects 2019: Highlights (ST/ESA/SER.A/423). Retrieved September, 2020 from https://population.un.org/wpp/Publications/Files/WPP2019_Highlights.pdf

UN News (2020a). Fall in COVID-linked carbon emissions won't halt climate change-UN weather agency chief. Retrieved September, 2020 from https://news.un.org/en/story/2020/04/1062332

UN News (2020b). Flagship UN study shows accelerating climate change on land, sea and in the atmosphere. Retrieved September, 2020 from https://news.un.org/en/story/2020/03/1059061

UNEP_United Nations Environment Programme. (2020). Retrieved September, 2020 from https:// www.unenvironment.org/explore-topics/sustainable-development-goals/why-do-sustainable-development-goals-matter/goal-12

UNFCCC-United Nations framework convention on climate change. (2020). The Paris agreement. Retrieved September, 2020 from https://unfccc.int/process-and-meetings/the-paris-agreement/ the-paris-agreement

WBCSD (2010). Vision 2050. Retrieved September, 2020 from https://www.wbcsd.org/Overview/ About-us/Vision2050

WBCSD (2020). Vision 2050 and the case for a refresh. Retrieved September, 2020 from https://www. wbcsd.org/Overview/About-us/Vision-2050-Refresh

WEF-World Economic Forum (2019). In depth: Shared prosperity, growth and competitivenessThe way forward. In K. Schwab (Ed.), The global competitiveness report 2019: How to end a lost decade of productivity growth. Retrieved September, 2020 from http://www3.weforum.org/docs/ WEF_TheGlobalCompetitivenessReport2019.pdf 
WEF-World Economic Forum (2020). Vision towards a responsible future of consumption: Collaborative action framework for consumer industries. Retrieved September, 2020 from http://www3. weforum.org/docs/WEF_Vision_Towards_a_Responsible_Future_of_Consumption_2020.pdf

World Bank. (2020a). How does the World Bank classify countries?. Retrieved September, 2020 from https://datahelpdesk.worldbank.org/knowledgebase/articles/378834-how-does-the-world-bank-classify-countries

World Bank. (2020b). Poverty. Retrieved September, 2020 from https://www.worldbank.org/en/ topic/poverty/overview

World Bank. (2020c). Poverty and shared prosperity 2020: Reversals of fortune. Washington: World Bank. https://doi.org/10.1596/978-1-4648-1602-4

World Bank. (2020d). World Bank country and lending groups. Retrieved September, 2020 from https://datahelpdesk.worldbank.org/knowledgebase/articles/906519-world-bank-country-and-lending-groups

World Data Lab. (2020). The world poverty clock. Retrieved September, 2020 from https://worldpoverty.io/

WWF-World Wildlife Fund. (2020). Water scarcity-overview. Retrieved September, 2020 from https://www.worldwildlife.org/threats/water-scarcity 



\title{
2.
}

\section{SUSTAINABILITY, SUSTAINABLE DEVELOPMENT AND CORPORATE SOCIAL RESPONSIBILITY}

\author{
Barbara Borusiak \\ Poznań University of Economics and Business
}

\begin{abstract}
The aim of current chapter is to present the genesis of 2 related phenomena: the sustainability and sustainable development concept, as well as the range of definitions in order to suggest a definition that can be applied in the whole e-book. The other objective is to present the Corporate Social Responsibility concept which, nowadays, is recognised as the process through which business contributes to sustainable development implementation. It was highlighted, however, that in the current situation, sustainable development may be achieved by new types of businesses built on the principles of saving resources (by recycling or reuse). For traditional businesses, based on non-renewable resources, CSR leading to sustainable development is a real challenge as it requires re-shaping business models.
\end{abstract}

Keywords: Corporate Social Responsibility, economic sustainability, environmental sustainability, social sustainability, sustainability, sustainable development. 


\section{2.l. The origin and meaning of sustainability and sustainable development as a concept}

At present, sustainability has become one of the most popular issues; both from theoretical and practical perspectives. At the same time, it poses, perhaps, the most demanding challenge for contemporary civilisation. Increasing consumption of products and services leads to the predatory usage of water, energy, land and generally, all resources. In 2019, by July 29, humanity had already used up nature's resource budget for the entire year according to the Global Footprint Network-an international sustainability organisation that has pioneered the Ecological Footprint. It is Earth Overshoot Day. Its date has moved up 2 months over the past 20 years to the $29^{\text {th }}$ of July 2019, the earliest date ever (Global Footprint Network).

In 2020, a pandemic year, Earth Overshoot Day fell on August 22. People travelled much less that year and it helped to push the date a little bit further. Nevertheless, the growing usage of resources is one of the most important reasons from catastrophic climate changes considered to be the main factor hindering sustainability (Khoshnevis Yazdi \& Dariani, 2019).

The concept of sustainability was originally coined in forestry, where it means never harvesting more than what the forest yields in new growth (Wiersum, 1995). The word Nachhaltigkeit (the German term for sustainability) was first used with this meaning in 1713 (Wilderer, 2007). The concept of sustainability and sustainable society was brought to mainstream politics by the Brundtland Commission report: Our common future, published in 1987 (Dixon \& Fallon, 1989). However, the definition presented in the report is relatively vague, underlying the complexities of sustainability. The vagueness of this concept, combined with its growing level of importance in national and international policy-making, has led to an extensive debate and a wide variety of definitions. The name sustainability is derived from the Latin sustinere (withstand, hold out). Sustain can mean 'maintain,' 'support,' 'uphold' or 'endure'. Such an explanation, however, does not make the term itself very clear or understandable. This is partly connected with the fact that there is another term: sustainable development, the meaning of which is very close (in Polish, for example, both sustainability and sustainable developed are translated in the same way). Thus, 2 approaches may be distinguished:

- sustainability and sustainable development are used interchangeably (Chang et al., 2017);

- due to the "growth" associations, sustainable development refers to development goals, although based on seeking balance between present and future access to resources (Sherren, 2006).

Basically, the first approach dominates in papers and books.

Some of the typical definitions of sustainability are summarised below (Chang et al., 2017): 
- sustainability is the ability of a human, natural or mixed system to indefinitely withstand or adapt to endogenous or exogenous change;

- sustainability is the relationship between dynamic human economic systems and larger dynamic, but normally slower, changing ecological systems, in which (a) human life can continue indefinitely, (b) human individuals can flourish, and (c) human cultures can develop;

- sustainability is an economic state in which the demands placed upon the environment by people and business to provide for future generations can be met without reducing the capacity of the environment;

- sustainability may be defined as the ability of anything, such as energy, environment, society, economy, water, or any technology, that can constantly remain sustained.

In the current e-book, we suggest accepting the very basic (and, at the same time, simple) definition, which says:

Sustainability is the search for balance between the present and future use of resources (Smith, 2015).

In other words it can be expressed as the principle that our (of humanity) obligation is to use what we need (but no more) so that our descendants shall not be deprived of what they need. This means that sustainability is a concept directly leading to another one-sustainable development, which, in turn, sheds more light on the needs of future generations.

Historically, SD—as a concept, is derived from economics as a discipline. The discussion regarding whether the capacity of limited natural resources would be able to continually support the existence of the increasing human population gained prominence with the Malthusian population theory in the early 1800s. In this theory, it was stated that the human population tended to grow in geometric progression, while subsistence could grow only in arithmetic progression, and for this reason, population growth was likely to outstrip the capacity of the natural resources to support the needs of the increasing population. However, later on, technological progress was recognised as a solution to the problem of the highly growing demand for resources. With time, global concerns heightened the discussion about non-renewability of some natural resources which threaten production and long-term economic growth, resulting from environmental degradation and pollution (Mensah \& Ricart Casadevall, 2019). And we should not forget that a community, according to a Nigerian tribal chief, consists of "many dead, few living and countless others unborn" (Kuhlman \& Farrington, 2010), which leads to the basic assumption of sustainable development-to think about future ones as expecting no less than we do and facing new challenges. According to the Brundtland Commission report: 
Sustainable development can be expressed as that meeting the needs of the current generation, without compromising the ability of future generations to meet their own needs (Mensah \& Ricart Casadevall, 2019).

Thus, environmental concern is important, but the basic argument is one of welfare, viewed within a context of inter-generational equity. We should care for the natural environment not because of its intrinsic value and beauty, but in order to preserve resources for future generations-our children.

The Brundtland Comission report highlights 2 concerns that should be reconciled: development and environment. They can also be interpreted as needs versus resources, or as short- versus the long-term. Today, however, sustainability is almost always seen in terms of 3 dimensions: social, economic and environmental (Robert, Parris, \& Leiserowitz, 2005). This is embodied in the definition of sustainable development adopted by the United Nations in its Agenda for Development:

Development is a multidimensional undertaking to achieve a higher quality of life for all people. Economic and social development, as well as environmental protection are interdependent and mutually reinforcing components of sustainable development (Kuhlman \& Farrington, 2010).

Have you heard about it?

Switzerland was the first country to add the term sustainability to its constitution in Article 2 (since January 1, 2000): "The Swiss Confederation supports the common welfare, the sustainable development, the internal cohesion and the cultural diversity of the country" (Spindler, 2013).

\subsection{From sustainable development to Corporate Social Responsibility}

Whereas the term "sustainable development" mainly started to be used in the 1980s, the framework of Corporate Social Responsibility (CSR) had already been established in the 1950s and 60s. Bowen defined CSR in 1953 as an obligation to pursue policies for making decisions and following lines of action, compatible with the objectives and values of society (Douglas, Doris, \& Johnson, 2004). In general terms, Corporate Social Responsibility encompasses the responsibilities that businesses have towards the societies within which these businesses operate. The European Commission uses the following definition: 
CSR is "a concept whereby companies decide voluntarily to contribute to a better society and a cleaner environment".

Specifically, CSR suggests that a business identifies its stakeholder groups and incorporates its needs and values within its strategic and operational decisionmaking process (Hartman, Rubin, \& Dhanda, 2007).

A useful working approach to CSR and sustainability is to identify CSR as the process through which sustainable development, as defined by Brundtland Commission report, is the goal (Hopkins, 2006). However, while sustainable development is a global postulate, addressed to all entities whose decisions have impact on resource management, including the state, corporations, non-profit organisations, other institutions and associations (including those international such as the European Union) and consumers, CSR describes the expected postulates addressed mainly to business entities. There is still a discussion on what aspects of business responsibility should be taken into account. According to Carroll (2016), there are 4 obligations that create a foundation or infrastructure for the business's responsibilities towards society:

- economic responsibility - the obligation of a business organisation to make money;

- legal responsibility-corporations must respect laws and regulations;

- ethical responsibility_corporations must behave as a good citizen in its society;

- philanthropic responsibility which is a voluntary activity guided by the business's desire to participate in social activities that are not mandated.

Nowadays, it is necessary to highlight environmental responsibility, which in face of the current climate catastrophic situation, must be considered.

The application of the CSR concept is a great challenge for enterprises due to the principle of profit maximisation, generally applicable in business, which results in increasing the scale of operations on the one hand, thus-bigger resource usage, and looking for cost decreases on the other; by the implementation of outsourcing, off-shoring and global supply chains. For this reason, in many corporations, CSR is only a kind of public relations technique. Nevertheless, there are some businesses in which CSR is embedded into their DNA, alike enterprises operating in circular economy based businesses, i.e., recycling and reuse.

\section{Questions / tasks}

1. Find examples (as many as possible) of predatory resource usage.

2. Explore data concerning the rate of resource usage by humankind. What countries are leading in this competition? What sectors are the most resource-consuming?

3. How does people's behaviour support the predatory usage of resources? 
4. What can be done to prevent people from predatory usage of natural resources (give as many examples as possible)?

5. What resources are running out the fastest? Find data to support and illustrate your answer.

6. Find out your Ecological Footprint and personal Earth Overshoot Day and learn about solutions to help us all survive on Earth.

7. Discuss the presented definitions of sustainability. What, from your point of view, is the core element of sustainability?

8. Organise an Oxford debate on the subject: Can needs be distinguished into those justified and unjustified?

9. Organise an Oxford debate on the subject: Can the present needs be met without compromising the ability of future generations to meet their own needs?

10. What is/are differences (if any) between sustainability and sustainable development?

11. How can sustainable development be achieved?

12. What are the most important obstacles of implementing the sustainable development concept?

13. Does sustainable development implementation mean that we should seek to manage our environment in order to restore prior conditions, to stabilise our current use, or to plan for anticipated needs of future generations?

14. Please, specify business stakeholder groups and their needs.

\section{References}

Carroll, A. B. (2016). Carroll's pyramid of CSR: taking another look. International Journal of Corporate Social Responsibility, 1(1). https://doi.org/10.1186/s40991-016-0004-6

Chang, R.-D., Zuo, J., Zhao, Z.-Y., Zillante, G., Gan, X.-L., \& Soebarto, V. (2017). Evolving theories of sustainability and firms: History, future directions and implications for renewable energy research. Renewable and Sustainable Energy Reviews, 72, 48-56. https://doi.org/10.1016/j.rser.2017.01.029

Dixon, J. A., \& Fallon, L. A. (1989). The concept of sustainability: Origins, extensions, and usefulness for policy. Society \& Natural Resources, 2(1), 73-84. https://doi.org/10.1080/08941928909380675

Douglas, A., Doris, J., \& Johnson, B. (2004). Corporate social reporting in Irish financial institutions. The TQM Magazine, 16(6), 387-395. https://doi.org/10.1108/09544780410563301

Hartman, L. P., Rubin, R. S., \& Dhanda, K. K. (2007). The Communication of Corporate Social Responsibility: United States and European Union Multinational Corporations. Journal of Business Ethics, 74(4), 373-389. https://doi.org/10.1007/s10551-007-9513-2

Hopkins, M. (2006). What is Corporate Social Responsibility all about? Journal of Public Affairs, 6(34), 298-306. https://doi.org/10.1002/pa.238

Khoshnevis Yazdi, S., \& Dariani, A. G. (2019). CO2 emissions, urbanisation and economic growth: evidence from Asian countries. Economic Research-Ekonomska Istraživanja, 32(1), 510-530. https://doi.org/10.1080/1331677X.2018.1556107

Kuhlman, T., \& Farrington, J. (2010). What is sustainability? Sustainability, 2(11), 3436-3448. https:// doi.org/10.3390/su2113436 
Mensah, J., \& Ricart Casadevall, S. (2019). Sustainable development: Meaning, history, principles, pillars, and implications for human action: Literature review. Cogent Social Sciences, 5(1). https:// doi.org/10.1080/23311886.2019.1653531

Robert, K. W., Parris, T. M., \& Leiserowitz, A. A. (2005). What is sustainable development? Goals, indicators, values, and practice. Environment: Science and Policy for Sustainable Development, 47(3), 8-21. https://doi.org/10.1080/00139157.2005.10524444

Sherren, K. (2006). Core issues. Reflections on sustainability in Australian University coursework programs. International Journal of Sustainability in Higher Education, 7(4), 400-413. https://doi. org/10.1108/14676370610702208

Smith, M. L. (2015). The origins of the sustainability concept: Risk perception and resource management in early urban centers. In Climate change, culture, and economics: Anthropological investigations (pp. 215-238). Bingley: Emerald Group Publishing Limited.

Spindler, E. (2013). The history of sustainability. The origins and effects of a popular concept. In I. Jenkins, \& R. Schröder (Eds.), Sustainability in tourism. A multidisciplinary approach (pp. 9-31).

Wiersum, K. F. (1995). 200 years of sustainability in forestry: Lessons from history. Environmental Management, 19(3), 321-329. https://doi.org/10.1007/BF02471975

Wilderer, P. A. (2007). Sustainable water resource management: the science behind the scene. Sustainability Science, 2(1), 1-4. https://doi.org/10.1007/s11625-007-0022-0 



\title{
3.
}

\section{SUSTAINABLE CONSUMPTION}

\author{
Barbara Borusiak \\ Poznań University of Economics and Business
}

\begin{abstract}
The aim of the current chapter is to present the essence of sustainable consumption and its basic rules: Reduce-Reuse-Recycle. Minimalism and sharing economy were presented as the manifestation of the Reduce rule. Reuse requires distribution systems which will give access to preowned products (in a broader scope), thus, they will provide products with a second life. This may be provided by alternative retail formats which are oriented towards the sale of second-hand products. Some of these formats, especially online applications, are becoming quite popular-their number, as well as the amount of their customers is rapidly growing. Also, traditional mainstream retailers have become involved in second-hand product sales.
\end{abstract}

Keywords: 3R formula, minimalism, responsible consumption, second-hand products, sharing economy. 


\subsection{The essence of sustainable consumption}

Sustainable consumption is defined as a decision-making process, taking the consumers' social and environmental responsibility into consideration in addition to individual preferences concerning a product's attributes (Vermeir \& Verbeke, 2008). The concept of socially responsible consumption has evolved over a period of 40 years. It has expanded from its beginning, during which it related only to environmental concerns, to now include a much wider range of categories (Prendergast \& Tsang, 2019). According to Webb, Mohr and Harris (2008), a socially responsible consumer is a person basing his or her acquisition, usage and disposition of products on the desire to minimise or eliminate any harmful effects and maximise the long-term beneficial impact on society and environment.

Terms, such as sustainable consumption, ethical consumption and green consumerism, are frequently used interchangeably (Jaiswal, 2012). The $3 \mathrm{R}$ concept describes 3 basic types of sustainable consumer behaviour: Reduce-Reuse-Recycle. Reduce the purchase and consumption of goods; Reuse existing goods that people have already purchased; and Recycle goods when they are completely exhausted, transforming them into a resource (Palmeira \& Musso, 2020).

Reduction poses a real challenge for the contemporary customer, as we have become accustomed to aspiring for more. For centuries, growing private possession was (and still is) a very important drive of economy.

There are 2 main paths of implementing the 'Reduce' rule:

- Buy less, possess less and use less (minimalism);

- Buy less, possess less but use as usual (sharing economy).

Reuse concerns using things for $\mathrm{a} 2^{\text {nd }}\left(3^{\text {rd }}\right.$, etc.) time, in accordance with the original purpose or not, but without vast modification. Reused products may be preowned by someone else or not.

Recycling is about converting waste into reusable materials or objects, and it is a process which usually requires complex technology. At the same time, it also requires selecting waste from those who generate it, also from consumers.

\subsection{Minimalism}

Minimalism is one of sustainable consumption manifestations and one of the fastdeveloping trends in wealthy societies. It is also named anti-consumerism, voluntary simplicity or deconsumption. Minimalism means deliberately limiting consumption to rational sizes that result from natural, individual, physical and mental characteristics of consumers, while emphasising responsible decision-making in this area. The most common expression of processes related to minimalism is mainly the limitation in quantitative and structural consumption. The Stanford Research 
Centre estimated the number of Americans who have voluntarily simplified their lives to be at several millions (Błoński \& Witek, 2019). Rapidly growing consumption and consumerism by some are regarded as a civilisation disease: on one hand, it leads to fast resource depletion, while on the other-more goods do not give people more happiness, the contrary-people suffer from an inability to enjoy their lives, experiencing constant dissatisfaction, nervous tension, fatigue, a constant lack of something. As stated by the renowned Polish sociologist-Zygmunt Bauman (2009): "Neither the exquisite taste of restaurant dishes, nor branded labels with high prices attached to gifts bought in the store, can match the value of happiness that could be brought by goods, the lack or shortage of which is to be compensated in this way". Needs are never fully satisfied and the more things people buy, the more this is felt. Therefore, some with to exclude themselves from the trap of consumerism and choose minimalism, which is a radical option in the reduction of consumption.

\subsection{Sharing economy}

The main assumption of a sharing economy was to make already produced goods more productively utilised. For example, private cars are traditionally only used only for a few hours a day, whereas sharing systems let them be used for much longer periods of time. Sharing economy is not quite a new concept, but for years, goods have been shared by families or cooperative members. Nowadays, sharing economy means a set of businesses which provide access to products (as well as services) and the opportunity to use them without their possession or basing on collaborative possession. The development of sharing economy is facilitated by community-based, on-line platforms such as:

- Co-working platforms: companies provide shared open work spaces for freelancers, entrepreneurs and work-from-home employees, i.e., WeWork;

- Car-, bike-sharing platforms: owners provide vehicles, with smartphone application-based access to them, for example, Sixt, Car2go, 4mobility;

- Peer-to-peer lending platforms: companies that allow individuals to lend money to other individuals at rates cheaper than those offered by banks, alike Zopa or Funding Circle;

- Fashion platforms: sites that allow individuals to rent their clothes or accessories, such as Hurr or My Wardrobe;

- Accommodation platforms: sites that allow individuals to rent out their spare bedrooms, for instance, Airbnb;

- Transportation platforms: sites that allow car owners to meet people needing transport, i.e., BlaBlaCar.

In general, the 8 categories of shared goods or services can be distinguished as follows: materials, products, product service systems, space, workforce, knowledge 
and education, as well as information and data (Plewnia \& Guenther, 2018). Alternative names for this phenomenon include gig economy, platform economy, access economy and collaborative consumption. The sharing economy is estimated to grow from $\$ 14$ billion in 2014 to $\$ 335$ billion by 2025 . This estimate is based on the rapid growth of Uber and Airbnb, as indicative (Yaraghi \& Ravi, 2017). Although the sharing economy is developing quickly, there is a lot of criticism of it, mainly concerning regulatory uncertainty, he risk of abuse. In some sectors, alike transportation, special licences may be required. Unlicensed individuals offering services may not be following sector regulations or paying the associated costs. This could mean giving them an advantage, enabling them to charge lower prices. Another concern is that lack of government control can lead to serious abuse of both parties in the sharing economy. This has been highlighted by numerous, highly publicised cases regarding, for instance, hidden cameras in rented rooms, lawsuits over unfair treatment of ridesharing contractors by the platforms that employ them. But there is much evidence that the sharing economy supports sustainable consumption. For example, it was found that car-sharing decreases average greenhouse gas emissions of households in North America (Martin \& Shaheen, 2011). What is also important from the point of view of sustainability: sharing economy has the potential to build a community and strengthen relationships (Philip, Ozanne, \& Ballantine, 2015).

\subsection{Second life and alternative retail formats}

Second life is used here as a gentle description of giving things a second life by the purchase of used products. It seems to be the least preferable way of becoming a conscious customer (Palmeira \& Musso, 2020). In contrast, second-hand product markets are developing dynamically (Herjanto, Scheller-Sampson, \& Erickson, 2016) and the number of second-hand shops has been growing at a much higher rate than other stores (Yan, Bae, \& Xu, 2015). They adopt one of the retail formats referred to as alternative retail formats. They may be classified using 2 criteria: first-the type of products sold (food and non-food), and the second: the method of communication and set of used assets (store based and e-commerce). In Table 1, the proposed classification of alternative retail formats is presented.

Alternative retail formats have existed for decades, but they were not very meaningful. Nowadays, they are gaining much more attention thanks to the growing consumer interest and their business models. In the case of food, this mainly relates to redistributing excess food or food products which, due to the short remaining expiry date, may have to be destroyed (Holweg \& Lienbacher, 2011), while in the case of non-food products, this regards the possibility of extending the usage cycle of products by giving them a second life. 
Table 1. Alternative retail formats classification

\begin{tabular}{|c|c|c|}
\hline & $\begin{array}{l}\text { Food alternative retail } \\
\text { formats }\end{array}$ & Non-food alternative retail formats \\
\hline $\begin{array}{l}\text { Store-based } \\
\text { formats }\end{array}$ & $\begin{array}{l}\text { Social supermarket } \\
\text { Food outlet }\end{array}$ & $\begin{array}{l}\text { Vintage/antique shop } \\
\text { Second hand shop } \\
\text { Charity store/thrift store } \\
\text { Pawn shop } \\
\text { Flea market/swap meet (permanent/occasional/regular) } \\
\text { Car boot sale } \\
\text { Commission shop }\end{array}$ \\
\hline E-commerce & $\begin{array}{l}\text { Food share platform } \\
\text { Food outlet }\end{array}$ & $\begin{array}{l}\text { Fashion share platform } \\
\text { Second-hand share platform } \\
\text { E-second-hand shop }\end{array}$ \\
\hline
\end{tabular}

Source: (Borusiak, 2020).

Consumers' pressure has led to steady growth in second-hand retail (Ferraro, Sands, \& Brace-Govan, 2016), forcing traditional retailers to take note. For example, one of the luxury brands-Ralph Lauren-looked for second-hand vintage pieces in order to sell them at flagship stores alongside new collections (Cervellon, Wigley, Carey, \& Harms, 2012). In 2019, Zalando opened Zircle in Berlin-a second hand shop with women's fashion items. Second-hand clothes have become fashionable in their own right (Beard, 2008). In November 2020, IKEA opened its first, pure second-hand store at the recycling gallery ReTuna in Eskilstuna. In this shop, visitors can buy IKEA furniture that has been given a new life after being repaired and restored to its former glory, but at a much lower price. What has been developing very fast are e-commerce platforms which allow customers to sell second-hand products. There are numerous such platforms, some of them specialising in fashion (alike Zalando Wardrobe app or Vinted), some are general, devoted to any kind of product (such as OLX in Poland, Bulgaria, Romania and Ukraine). Second-hand stores have become an accepted and well-established retail format offering an authentic alternative to regular outlets and supporting sustainable consumption by giving people the access to second-hand products.

\section{Questions / tasks}

1. $3 \mathrm{R}$ formula-the basic one, describing sustainable consumption rules-has several extensions. Find them and discuss.

2. Find data illustrating the sentence: people buy more than they can consume.

3. Prepare a presentation on fast fashion and its impact on the environment.

4. Find data concerning the fashion product life cycle. What is the frequency of buying fashion products on various markets? 
5. What is the role of celebrities in $3 \mathrm{R}$ formula implementation? Find good and bad examples.

6. Do you have an idea how to promote the $3 \mathrm{R}$ formula? Prepare a presentation concerning chosen (from a range of many) $3 \mathrm{R}$ activities and their promotion.

7. Indicate how you can apply the $3 \mathrm{R}$ formula in your daily life.

8. What are the main obstacles of the $3 \mathrm{R}$ formula implementation?

9. What are the pros and cons of second-hand shopping (from any perspective that comes to mind)?

10. Many people are not eager to buy second-hand products. What do you think is the reason for this?

11. Discuss the positive and negative consequences of gig economy companies (e.g. Uber) for all involved parties and for an economy in general.

\section{References}

Bauman, Z. (2009). Sztuka życia. Kraków: Wydawnictwo Literackie.

Borusiak, B. (2020). Retail formats and alternative retail formats: The mechanisms for the emergence and evolution. In F. Musso, \& E. Druica (Eds.), Handbook of research on retailing techniques for optimal consumer engagement and experiences (pp. 184-204). IGI Global. http://doi. org/10.4018/978-1-7998-1412-2.ch009

Beard, N. D. (2008). The branding of ethical fashion and the consumer: A luxury niche or mass-market reality? Fashion Theory, 12(4), 447-467. https://doi.org/doi:10.2752/175174108X346931

Błoński, K., \& Witek, J. (2019). Minimalism in consumption. Annales Universitatis Mariae Curie-Skłodowska, sectio H-Oeconomia, 53(2). https://doi.org/10.17951/h.2019.53.2.7-15

Cervellon, M. C., Wigley, S. M., Carey, L., \& Harms, T. (2012). Something old, something used. International Journal of Retail \& Distribution Management, 40(12), 956-974. https://doi. org/10.1108/09590551211274946

Ferraro, C., Sands, S., \& Brace-Govan, J. (2016). The role of fashionability in second-hand shopping motivations. Journal of Retailing and Consumer Services, 32, 262-268. https://doi.org/10.1016/j. jretconser.2016.07.006

Herjanto, H., Scheller-Sampson, J., \& Erickson, E. (2016). The increasing phenomenon of second-hand clothes purchase: Insights from the literature. Jurnal Manajemen Dan Kewirausahaan, 18(1), 1-15. https://doi.org/10.9744/jmk.18.1.1-15

Holweg, C., \& Lienbacher, E. (2011). Social marketing innovation: New thinking in retailing. Journal of Nonprofit \& Public Sector Marketing, 23(4), 307-326. https://doi.org/10.1080/10495142.2011 .623548

Jaiswal, N. (2012). Green products. Availability, awareness and preference of use by the families. Indian Journal of Environmental Education, 12, 21-25.

Martin, E. W., \& Shaheen, S. A. (2011). Greenhouse gas emission impacts of carsharing in North America. IEEE Transactions on Intelligent Transportation Systems, 12(4), 1074-1086. https://doi. org/doi:10.1109/TITS.2011.2158539

Palmeira, M., \& Musso, F. (2020). 3Rs of sustainability values for retailing customers as factors of influence on consumer behavior. In Handbook of Research on Retailing Techniques for Optimal Consumer Engagement and Experiences (pp. 421-444). 


\section{3.}

Sustainable consumption

Philip, H. E., Ozanne, L. K., \& Ballantine, P. W. (2015). Examining temporary disposition and acquisition in peer-to-peer renting. Journal of Marketing Management, 31(11-12), 1310-1332. https:// doi.org/doi:10.1080/0267257x.2015.1013490

Plewnia, F., \& Guenther, E. (2018). Mapping the sharing economy for sustainability research. Management Decision, 56(3), 570-583. https://doi.org/10.1108/md-11-2016-0766

Prendergast, G. P., \& Tsang, A. S. L. (2019). Explaining socially responsible consumption. Journal of Consumer Marketing. https://doi.org/10.1108/JCM-02-2018-2568

Vermeir, I., \& Verbeke, W. (2008). Sustainable food consumption among young adults in Belgium: Theory of planned behaviour and the role of confidence and values. Ecological Economics, 64(3), 542-553. https://doi.org/10.1016/j.ecolecon.2007.03.007

Webb, D. J., Mohr, L. A., \& Harris, K. E. (2008). A re-examination of socially responsible consumption and its measurement. Journal of Business Research, 61, 91-98. https://doi.org/10.1016/j. jbusres.2007.05.007

Yan, R.-N., Bae, S. Y., \& Xu, H. (2015). Second-hand clothing shopping among college students: the role of psychographic characteristics. Young Consumers, 16(1), 85-98. https://doi.org/10.1108/ yc-02-2014-00429

Yaraghi, N., \& Ravi, S. (2017). The current and future state of the sharing economy. Brookings India IMPACT Series No. 032017. 



\title{
4.
}

\section{PRINCIPLES OF THE UNITED NATIONS GLOBAL COMPACT}

\author{
Anna Mravcová \\ Faculty of Economics and Management, Slovak University of Agriculture in Nitra \\ Jana Gálová \\ Faculty of Economics and Management, Slovak University of Agriculture in Nitra
}

\begin{abstract}
The United Nations Global Compact represents one of the biggest voluntary initiatives under the United Nations organisation. This initiative was founded in 2000. It is strongly connected with Corporate Social Responsibility and efforts in achieving sustainability as it is a call for businesses worldwide to contribute towards sustainable world development in economic, social as well as environmental areas. Until last year, when the UNGC celebrated its $20^{\text {th }}$ anniversary, it already had over 11,500 participants all around the world. This fact can have significant impact on achieving its goals which were set in the form of 10 principles divided into 4 main areas, where the positive and sustainable operating of business as well as other types of organisations is much than needed today. Therefore, in the text of this subchapter, the basic information about the very Global Compact initiative is presented, as well as its 10 universal principles set in the areas of human rights, labour standards, environment and anti-corruption, through which the participants are required to take strategic actions in achieving broader societal goals, mainly current Sustainable Development Goals, the interconnection of which is also presented and highlighted. The aim is to help understand the importance of this UN initiative for creating a better and sustainable world by incorporating business and other organisations.
\end{abstract}

Keywords: 10 principles, companies, sustainability, Sustainable Development Goals, UN Global Compact. 


\subsection{Theoretical background}

The United Nations Global Compact (UNGC) represents a voluntary initiative, founded in 2000, after a speech by the former UN General Secretary, Kofi Annan, at the World Economic Forum in 1999. The intention was to start a dialogue with business and move the $\mathrm{UN}$ towards a more proactive role involving business as part of the solution (Kell, 2013; Rasche, 2010). The UNGC therefore represents "a call to companies everywhere to align their operations and strategies with ten universally accepted principles in the areas of human rights, labour, environment and anti-corruption, and to take strategic actions to advance broader societal goals, such as the Sustainable Development Goals (SDGs) (see UNDP, 2015), with a focus on cooperation and innovation" (more in UNGC, 2020c; RELX, 2020). It is "a call to business worldwide to help build the social and environmental framework to support and ensure the continuation of open and free markets whilst ensuring that people everywhere have a chance to share the benefits of the new global economy" (IOE, 2020).

It is a leadership programme for the development, implementation and disclosure of responsible corporate practices. Apart from business, the UNGC also involves non-business participants, mainly trade unions, as well as human rights and environmental non-governmental organisations. The UNGC is the largest corporate sustainability initiative in the world with more than 11,500 participants based in 156 countries (UNGC, 2000b). Its mission is also to mobilise a global movement of sustainable companies and stakeholders, and to promote activities that contribute to SDGs, creating a better and sustainable world (UNGC, 2020c).

The UNGC is not a regulatory tool. It is like a place for discussion and a network for communication involving governments, companies and labour organisations, the actions of which are aimed at influence.

The UNGC consists of 10 principles that shall define a participant's value system and approach towards doing business. These principles (see Figure 1) include the mentioned areas (IOE, 2020):

- human rights - derived from the Universal Declaration of Human Rights;

- labour standards - derived from the International Labour Organization 's(ILO) Declaration on Fundamental Principles and Rights at Work;

- environment-derived from the Rio Principles on Environment and Development;

- anti-corruption-derived from the UN Convention against Corruption.

Generally, the UNGC signatories/participants are then required to (IOE, 2020):

- make the 10 principles an integral part of their business strategies and everyday actions;

- create an annual Communication on Progress, a public disclosure to stakeholders (investors, consumers, civil society, governments, etc.) on progress made in implementing the 10 principles and in supporting broader UN development goals;

- advocate for the Global Compact. 


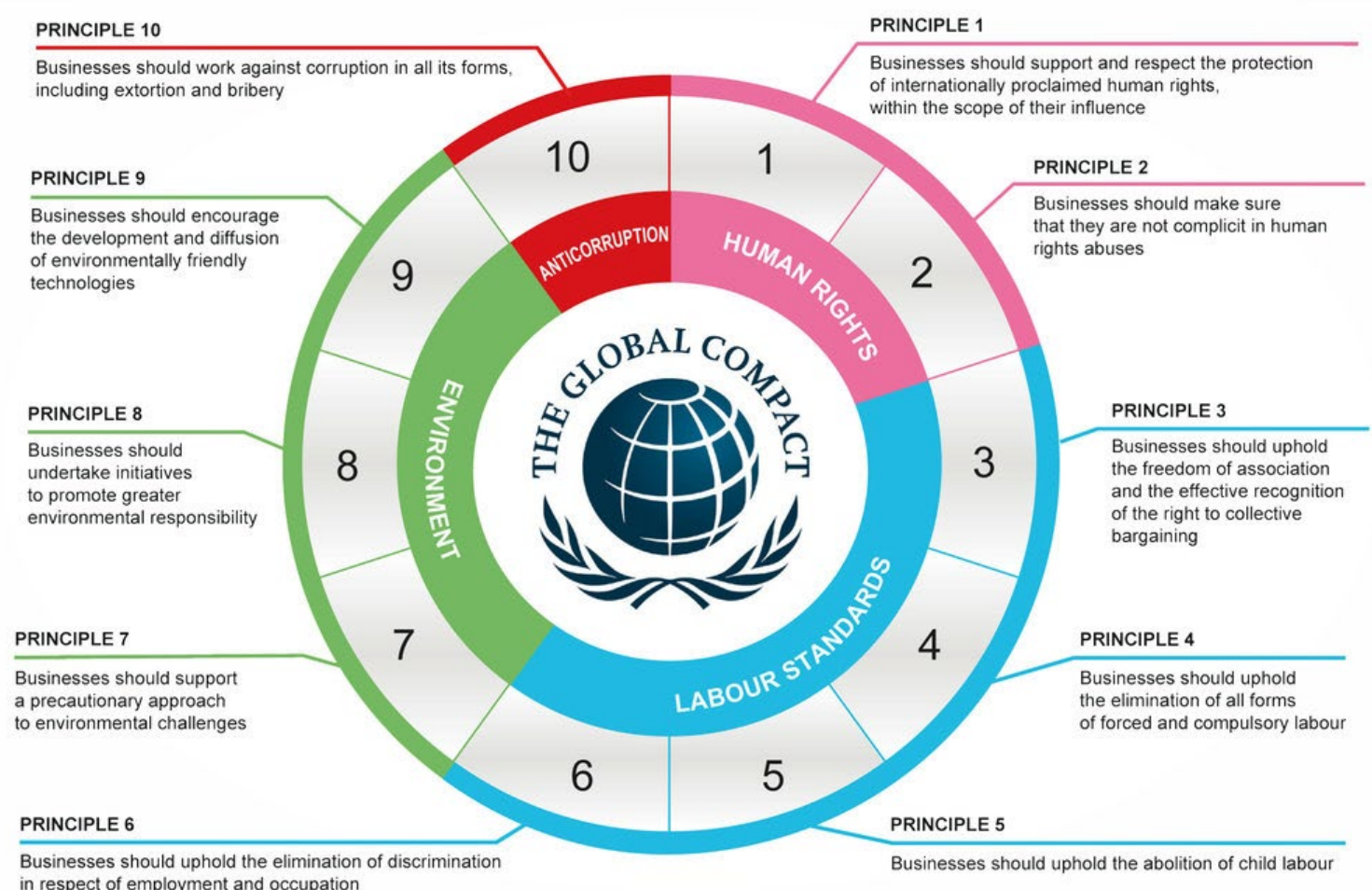

Figure 1. Ten principles of the UN Global Compact

Source: (BusinessHub4 Sustainability, 2020).

By incorporating the 10 UNGC principles into strategies, policies as well as procedures, and establishing a culture of integrity, companies confirm their basic responsibilities towards people and the planet, also setting the platform for longterm success (Global Compact Network Canada, 2019).

It can be said that the UNGC, as the largest global governance, voluntary corporate responsibility initiative in the world, addresses the social and ecological responsibilities of multinational corporations. Its underlying idea is that all business participants, NGOs, organised labour, UN agencies and governments, make an active contribution to achieving UN goals and UNGC principles (Kell, Slaughter, \& Hale, 2007; Thérien \& Pouliot, 2006; Williams, 2004) through incorporating them into their policies and strategies. It needs to be highlighted that, compared to other initiatives, the UNGC has considerable geographic reach (as it covers more than 150 countries) and also moral legitimacy as well as political support of the UN with its 193 Member States (Ruggie, 2001).

Therefore, the UNGC is also often introduced as part of an emerging global institutional infrastructure for corporate responsibility (Vogel, 2008; Waddock, 2008). 


\subsection{Principles of the UN Global Compact}

The main goal ofthe UNGC is that business and other participating organisations integrate, support and promote the set of 10 principles divided into the 4 mentioned areas: human rights, labour standards, the environment and anti-corruption. The level of their engagement shows their ability to encourage these principles in their field of operation.

\section{Human rights}

Principle 1: Businesses should support and respect the protection of internationally proclaimed human rights.

Principle 2: Assuring businesses are not complicit in the abuse of human rights.

One of the most challenging areas in every sphere of sustainability as well as in the area of business sustainability is the respect and support for human rights. As already mentioned, these 2 principles are derived from the world-known document-the Universal Declaration of Human Rights, adopted in December 1948 by the UN General Assembly in Paris. The Declaration was inspired by experiences from World War 2, aimed at avoiding similar catastrophes in the future. Therefore, the goal of these principles is to make businesses and organisations compatible with the UN Global Compact and Corporate Social Responsibility values (more in UNGC, 2020d; Gonzales-Perez \& Leonard, 2017).

In the past, human rights were only concerned with states and were only addressed by international human rights instruments. However, during last decade, still more companies (no matter the size, location or industry) were confronted with the idea that they should address and adopt human rights frameworks in their activities (Gonzales-Perez \& Leonard, 2017, p. 127).

It can be said that these principles define the general expectations of the UNGC in the field of human rights, mainly, as already stated, in the field of respect for and the promotion of human rights. Respect for human rights means that a company should try to avoid human rights violations. Business are also encouraged to support and protect human rights, for example, through core business, strategic social investment, philanthropy, public policy engagement, advocacy and/or partnerships, as well as other collective action, actively and positively. Special attention shall be paid to the rights of vulnerable groups, including women, children, individuals with disabilities, indigenous people, migrant workers, seniors, etc. (UNGC, 2000a). Business shall also avoid the complicity (participation in human rights violation) beyond their core business activities. Ways for business to contribute to human rights then also include job creation, development of goods and services that help people meet their basic needs, the promotion of public policies that encourage 
social sustainability, partnerships with other business having greater impact, and strategic social investments (Kenton, 2020).

\section{Labour standards}

Principle 3: Businesses should uphold the freedom of association and the effective recognition of the right to collective bargaining.

Principle 4: Businesses should eliminate all forms of forced and compulsory labour. Principle 5: Businesses should effectively abolish child labour.

Principle 6: Businesses should eliminate discrimination in respect of employment and occupation.

These 4 principles are derived from the ILO Declaration on Fundamental Principles and Rights at Work, which was adopted in 1988. According to it, all Member states have an obligation arising from their membership in the Organisation to respect, promote and realise the principles concerning fundamental rights. The Declaration mentions 8 conventions, which involve freedom of association and bargaining, abolition of forced labour, effective abolition of labour by children before the completion of compulsory education, and no workplace discrimination. These rights are universal for everyone, no matter what the economic and social development level of the country (more in, UNGC, 2000a; Gonzales-Perez \& Leonard, 2017).

The $3^{\text {rd }}$ principle concretely means that both workers and employers have the right to form, associate and manage their own organisations in promoting their interests, without the intervention of the state or any other entity freely and voluntarily. Workers have the right to an environment free of violence, pressure, fear and threats. This freedom, as well as these rights, also allow workers and organisations to defend their economic and social interests. This principle also allows to point out that collective bargaining is a voluntary process through which employers and workers can constructively discuss and negotiate their relationships and working conditions (UNGC, 2000a).

The $4^{\text {th }}$ principle is focused on avoiding any work or services that is required from any person under the threat of punishment or for which that person has not voluntarily offered (UNGC, 2000a). The next principle relates to the previous one and it is focused on prohibition of child labour. However, this term should not be used interchangeable with the terms-youth employment or student work. Under the term 'child labour', we understand a form of exploitation that is a violation of human rights, it is recognised and defined by international instruments. The basic international standards distinguish what is acceptable and what is unacceptable work for children (more in, UNGC, 2000a).

The $6^{\text {th }}$ principle is aimed at avoiding discrimination in employment and occupation, which means treating people differently or less favourably because of 
the various characteristics, mostly: race, sex, culture, religion, political opinion, nationality, social origin, age, disability, trade union membership, sexual orientation, etc. Discrimination can be direct or indirect, and it can arise in various areas and issues, for example, in terms of access to employment as well as in the treatment of employees at work. Its avoidance is mainly the task of organisations. Simply said, no discrimination means that workers are selected based on their ability to do a job and that there is no distinction, exclusion or preferences made in other areas (more in, UNGC, 2000e).

\section{Environment}

Principle 7: Businesses should support a precautionary approach to environmental challenges.

Principle 8: Businesses should undertake initiatives to promote greater environmental responsibility.

Principle 9: Businesses should encourage the development and diffusion of environmentally-friendly technologies.

Three UNGC environment principles reflect the foundation of corporate environmental responsibility. They are derived from the Rio Declaration on Environment and Development adopted in 1992, which consists of many principles to guide future international sustainable development and to address environmental challenges such as climate change, drinking water availability, pollution, ecosystems damages, waste production, deforestation, land degradation, etc. (Gonzales-Perez \& Leonard, 2017). These principles pay importance to the precautionary approach towards the environment, thus, when there is reasonable suspicion of harm, decision-makers need to apply precaution and consider the degree of insecurity that appears from scientific evaluation. This is connected to the Rio Declaration in which it is stated that businesses have the responsibility to ensure that their activities do not endanger the environment. There is also a call to support environmentally-friendly technologies, which protect the environment, are less polluting, use all resources in a more sustainable manner, recycle more of their waste/products and handle residual wastes in a more acceptable manner (more in, UNGC, 2000a). In other words, the UNGC member organisations are expected to act in an environmentally-friendly way and to take environmental challenges into account. Moreover, they also need to recognise the link between environmental issues and social as well as development priorities to contribute to the better and sustainable future of the world.

\section{Anti-corruption}

Principle 10: Businesses should work against corruption in all its forms, including extortion and bribery. 
The last principle is focused on another big, world-wide challenge-corruption. It was additionally added to the UNGC in 2004 and it derived from the UN Convention Against Corruption as the first legally binding international anticorruption tool. This Convention requires the implementation of measures for preventing and criminalising corruption from all its members. Limiting corruption, setting and enforcing sanctions were, in the past, a task for public authorities, however, in previous years, the civil society and private sector have started to assume a proactive approach towards fighting corruption. It is very important for every area to better world development, as "corruption interferes with sustainable development, skews competition, obstructs economic growth, incurs severe legal penalties, affects reputations and undercuts liberal economic mechanisms" (Gonzales-Perez \& Leonard, 2017, p. 129). Therefore, this principle requires UNGC participants to avoid bribery, extortion and other forms of corruption, while developing policies and programmes to address corruption internally and within their supply chains. "Corruption can take on various forms and companies should work collectively and participate in creating a more transparent global economy" (UNGC, 2000a).

\subsection{UN Global Compact and Sustainable Development Goals}

Although we can see a different nature and aim of these 2 initiatives, both the UNGC and the SDGs operate under the UN and therefore, share some common features in terms of how they approach responsible management (Rasche, 2020, p. 1). While, as earlier mentioned, the UNGC reflects a voluntary initiative for which the organisations can sign up, the SDGs do not represent any standard or initiative which organisations, corporations or states can join. SDGs reflect the UN agenda for sustainable development that shall be fulfilled by the year 2030 and states can just support and promote them, behaving accordingly, to reach them as closely as possible. However, as also mentioned, the UNGC and its 10 principles are strongly connected with the sustainable development and reaching SDGs. Involved corporations, as well as other organisations, are expected to behave and act sustainably in line with these sustainable goals.

Consequently, it may be said that the long-term strategy of the UNGC is to enhance business awareness and action to support achieving the SDGs by 2030 (UNGC, 2020b). The UNGC tries to achieve its goal of spreading the UN mission, including achieving Sustainable Development Goals and the implementation of the 10 principles by encouraging growth of signatory organisations, and through establishing local networks and by encouraging dialogue on specific policy areas (Voegtlin \& Pless, 2014, p. 7-8). In Figure 2, the interconnection among the 10 
principles of the UN Global Compact and the Sustainable Development Goals is demonstrated.

\section{THE TEN PRINCIPLES}

of the United Nations Global Compact
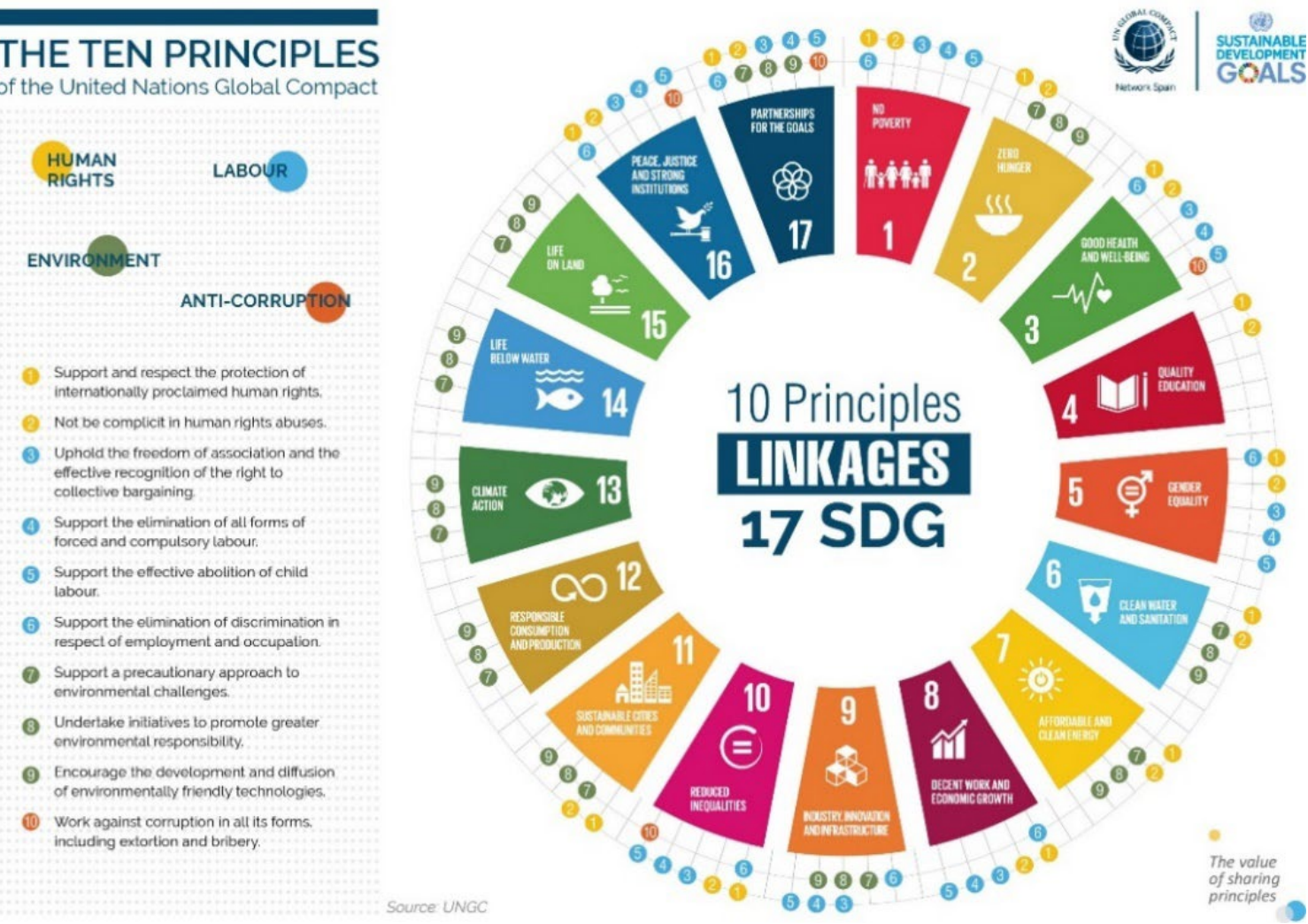

Figure 2: The UNGC Principles and SDGs

Source: (FCCO Construction).

The sustainability of a company begins with its value system and a principlebased approach to doing business. This means operating in a way meeting basic responsibilities in the area of human rights, labour, the environment and anticorruption. Responsible businesses apply the same values and principles wherever they operate and know that good practices in one area do not balance out problems in another. Therefore, it can be stated that through implementing the above mentioned UN Global Compact principles into business strategies, policies and practices, companies maintain their basic responsibilities and they are also creating a direction for long-term success (see more in: UNGC, 2000a). The participants are required to engage in specific business practices that benefit the people and the planet while pursuing profitability with integrity. For creating a better world, all 
member organisations are required to implement the established principles. They also should promote and support these principles in public and try to meet them as closely as possible (more also in, Kenton, 2020).

\section{Questions / tasks}

1. What potential do you see in the UN Global impact initiative for achieving sustainable development?

2. In your opinion, which key area of Global Impact is the most important and why?

3. According to the knowledge and information from the text, create your own list of the 10 UNGC principles corresponding to your subjective view and preferences, and explain it.

4. Explain, why is UN Global Impact necessarily connected with achieving sustainability?

5. Study the following links. Then, find, write and describe the interconnections among the UN Global Compact principles and Sustainable Development Goals:

a) https://www.unglobalcompact.org/what-is-gc/mission/principles

b) https://www.undp.org/content/undp/en/home/sustainable-developmentgoals.html

\section{References}

BusinessHub4 Sustainability. (2020). United Nations Global Compact. Trondheim: Business hub for sustainability. Retrieved October, 2020 from https://bh4s.no/reporting-and-communication/ united-nations-global-compact

FCCO Construction. The ten principles of the United Nations Global Compact. Madrid: FCC. Retrieved October, 2020 from https://www.fccco.com/en/sustainability/community/ten

Global Compact Network Canada. (2019). Corporate sustainability starts with a company's value system and a principles-based approach to doing business. Retrieved October, 2020 from https:// www.globalcompact.ca/about/ungc-10-principles/

Gonzales-Perez, M. A., \& Leonard, L. J. (2017). The UN Global Compact. In A. de Jonge, \& R. Tomasic, Research handbook on transnational companies (pp. 117-138). Cheltenham: Edward Elgar Publisher.

IOE. (2020). United Nations Global Compact. Geneva: International Organization of Employers.

Retrieved October, 2020 from https://www.ioe-emp.org/international-organisations/united-nations-global-compact

Kell, G. (2013). 12 years later: Reflections on the growth of the UN Global Compact. Business \& Society, 52(1), 31-52. https://doi.org/10.1177/0007650312460466

Kell, G., Slaughter, A. M., \& Hale, T. (2007). Silent reform through the Global Compact. UN Chronicle, 44, 26-30.

Kenton, W. (2020). Investopedia: United Nations Global Compact. Retrieved October, 2020 from https://www.investopedia.com/terms/u/un-global-compact.asp 
Rasche, A. (2010). A necessary supplement: What the United Nations Global Compact is and is not. Business \& Society, 48(4), 511-537. https://doi.org/10.1177/0007650309332378

Rasche, A. (2020). The united nations global compact and the Sustainable Development Goals. In Research handbook of responsible management (pp. 228-241). Cheltenham: Edward Elgar Publishing. https://doi.org/10.4337/9781788971966

RELX. (2020). United Nations Global Compact. London: RELX Sustainable Development Goals (SDGs) Resource Centre. Retrieved October, 2020 from https://sdgresources.relx.com/united-nations-global-compact

Ruggie, J. G. (2001). Global_Governance.Net: The Global Compact as learning network. Global Governance, 7(4), 371-378. https://doi.org/10.2307/27800311

Therien, J. P., \& Pouliot, V. (2006). The Global Compact: Shifting the politics of international development? Global Governance, 12(1), 55-75. https://doi.org/10.2307/27800598

UNDP. (2015). Sustainable Development Goals. United Nations. Retrieved October, 2020 from https:// www.undp.org/content/undp/en/home/sustainable-development-goals.html

UNGC. (2000a). The ten principles of the UN Global Compact. United Nations. Retrieved October, 2020 from https://www.unglobalcompact.org/what-is-gc/mission/principles

UNGC. (2000b). United Nations Global Compact. United Nations. Retrieved October, 2020 from https://www.unglobalcompact.org/

UNGC. (2020c). Our mission. United Nations. Retrieved October, 2020 from https://www.unglobalcompact.org/what-is-gc/mission

UNGC. (2020d). SDGs explained for business. United Nations. Retrieved October, 2020 from https:// www.unglobalcompact.org/sdgs

UNGC. (2020e). What is GC. United Nations. Retrieved October, 2020 from https://www.unglobalcompact.org/what-is-gc

Voegtlin, Ch., \& Pless, N. M. (2014). Global governance: CSR and the role of the UN Global Compact. Journal of Business Ethics, 122(2), 179-191. https://doi.org/10.1007/s10551-014-2214-8

Vogel, D. (2008). Private Global Business regulation. Annual Review of Political Science, 11(1), 261-282. https://doi.org/10.1146/annurev.polisci.11.053106.141706

Waddock, S. (2008). Building a new institutional infrastructure for corporate responsibility. Academy of Management Perspectives, 22(3), 87-108. https://doi.org/10.5465/AMP.2008.34587997

Williams, O. F. (2004). The UN Global Compact: The challenge and the promise. Business Ethics Quarterly, 14(4), 755-774. https://doi.org/10.1007/978-1-4020-8429-4_15 


\title{
5.
}

\section{SUSTAINABLE DEVELOPMENT AND CORPORATE SOCIAL RESPONSIBILITY- ORGANISATIONAL LEVEL}

\author{
Magdalena Stefańska \\ Poznań University of Economics and Business \\ Blaženka Knežević \\ Faculty of Economics and Business, University of Zagreb
}

\begin{abstract}
Sustainable development and CSR are included in the strategies of most companies. To learn more what companies do for the environment and society-usually, one can visit their websites and read about their SD or CSR activities in reports. However-the quality of such reports differs-from minimum information to very deep immersion into explaining to stakeholders how an organisation understands its role in society.

The aim of this chapter is to explain how sustainable development (SD) and Corporate Social Responsibility (CSR) influence corporate strategy, both on a corporate level-mission, vision and its goals, and functional areas of organisation.
\end{abstract}

Keywords: business functions, corporate strategy, mission, objectives, organisational level, sustainable development, vision. 


\section{5.l. Theoretical background}

The concept of SD has very strong influence on organisations, indicating the directions of strategic development for them. The global adoption of Sustainable Development Goals (SDGs) and the 2030 Agenda for Sustainable Development has focused both governments and finance institutions on the need for more integrated sustainability strategies. In some organisations, it is reflected at the level of selected functions-e.g. in the area of logistics and in others, it permeates all spheres of business activity. A narrow or broad approach is conditioned by a number of internal and external factors. Among those internal, one should indicate the type of organisation, the approach of the company's owners to the idea of SD and the managers/board themselves to implement SD solutions. The external factors should include, first of all, economic, legal, political, socio-cultural and technological conditions. The implementation of SD goals is strongly connected with CSR, which may be perceived as the concept translating SD to business.

As far as CSR is concerned, it provides companies (small, medium and large) with a way to structure, manage and achieve SDGs (Sustainable Development Goals) and values. Large companies, due to their scope of business, owned capital and unique, rare and difficult to copy capabilities, initiate a large scope of initiatives of different kinds and on a big scale. Locally operating small companies, often family businesses, mark their presence in society by means of activities, noticeable and important for local communities. This is their advantage. Since they are closer to inhabitants, they have a better understanding of needs and their engagement positively influences business.

The idea of CSR is reflected both at strategic and operational levels. Strategic CSR influences all decisions and activities in all aspects, starting from defining core values, mission, vision, and the way they are implemented. Nowadays, these values have become crucial, because they are not only about defining business values, but also those general for society, the environment and owners (for example, social, moral and human values, as well as those more detailed: respect and responsibility, shared values, common good and others). Business cannot exist without such values. It is the declaration of an organisation-the promise to employees, shareholders, the whole society. However the attitude of a company towards CSR takes on such forms as: reactive, defensive, adaptive and proactive. It depends on the level of awareness regarding the overall influence of an organisation on the surrounding environment and stakeholders. The highest level-proactive means, that is a company initiates solutions to achieve CSR goals, while reactive means are oriented towards protection against threats. The type of strategy implies the level of involvement in activities aimed at achieving goals related to CSR.

In turn, operational CSR concerns the instruments and measurement of effectiveness and efficiency regarding activities undertaken in such areas as: relations 
with decision-makers, human resources management, marketing, purchasing and logistics, finance as well as strategy (van Tulder et al. 2009, p. 8).

The idea of strategic CSR is reflected at every stage of strategy formulation, i.e. at the level of mission and vision, in defining stakeholders and their needs, defining goals and tools for their implementation. The mission is the company's obligation to behave in a specific way.

\subsection{Elements of sustainable development at the corporate level}

There are 3 levels in strategic management: (1) corporate, (2) strategic business units-SBUs, and (3) functional strategies in each unit. Each level is connected with other types of responsibilities and decisions.

The strategic general direction is defined and developed at the corporate level. In strategic management, the direction of the organisation's development is determined by its mission and vision which, at the same time, influences strategies and goals defined at the level of SBUs. Vision is a pattern of organisational values that underlies a unique visionary blueprint for an organisation's future. The management's strategic vision should be realistic when considering the market, competitive, technological, economic, regulatory and societal conditions the company is likely to encounter, and it ought to further be realistic about the company's resources and capabilities.

The mission of an organisation contains the main values important for the stakeholders and environment, and thus, valued by the company. Mission statements are related to the organisational culture of a company, i.e. they are expressed as a set of norms and principles that guide its relations with employees within it and entities around it. As with vision statements, mission statements must be based on the ethical values of the organisation. Those values normally include concepts such as honesty but become more specific in a mission statement. The mission statement answers questions such as: 'Who are we?', 'What do we do?', 'Who are our customers?', 'What is important for us?.' There are 9 detailed categories that mission statements often discuss, specifying general goals: target markets, principal products/ services, geographic domain, technological advantage, economic goals, philosophy, identity, reputation, employee concern (Bowen, 2018). Not every mission statement contains all of these elements, as many are dependent upon industry, size of the organisation, consumer or business orientation, strategic publics/stakeholders, competitive market position, and so forth (Bowen, 2018).

One may find examples of organisations in which mission and vision defined at the top level strongly differs from implementation at the functional level (for example, in the case of Unilever's brands Dove and Axe). 
Both mission and vision indicate the key and core values important for an organisation-employees, environment, reputation, etc. They determine its identity, organisational culture and its aspirations for the future. They also provide motivation for workers and synergy for the organisation. Defining them is not sufficient if they are not known to employees and translated into their tactical and operational activities. An institution is empowered by the commitment of its personnel to its shared principles and values.

To sum up, an interesting question is whether companies include sustainability and sustainable development in their core values and are expressed by mission and vision. Table 1 contains exemplificatory missions of selected Polish private companies, ranked by value in 2019 according to Forbes (Szeligowski, 2019) and selected, successful large Croatian private companies (Croatia.eu land and people, n.d.).

Table 1. Mission and vision of selected Polish and Croatian companies-examples

\begin{tabular}{|c|c|}
\hline & Mission and vision statements. Values \\
\hline $\begin{array}{c}\text { Cyfrowy } \\
\text { Polsat }\end{array}$ & $\begin{array}{l}\text { Mission: } \\
\text { Our mission is to create and deliver the most attractive TV content, telecommunication } \\
\text { products and other services for the home, as well as residential and business customers, } \\
\text { using state-of-the-art technologies to provide top quality, multi-play services that match } \\
\text { the changing needs of the market, while maintaining the highest possible level of customer } \\
\text { satisfaction. } \\
\text { Vision: } \\
\text { (...) the permanent growth of the value of Cyfrowy Polsat for its Shareholders. We intend } \\
\text { to achieve this goal by implementing the major elements of our operational strategy. } \\
\text { Basic values (included in non-financial report) } \\
\text { - safety-thanks to state-of-the-art technologies, we offer safe products and services for } \\
\text { households, and thanks to cooperation with rescue services, we take care of safety in the } \\
\text { mountains and by the water; } \\
\text { - aid to children - through activities of the Polsat Foundation, and the employees volun- } \\
\text { teering, we care for the health of children who occupy a special place from the point of } \\
\text { view of the Groups social impact; } \\
\text { - promotion of sports and activities-we root for, promote and support volleyball, football } \\
\text { and other sports disciplines through sponsoring, supporting amateur and professional } \\
\text { events and television broadcasts. }\end{array}$ \\
\hline LPP S.A. & $\begin{array}{l}\text { Mission } \\
\text { "LPP is a socially responsible, Polish family company". We help our customers express their } \\
\text { emotions and realise their dreams through the way they look and feel. } \\
\text { Vision } \\
\text { Passion drives us forward, making our company the best fashion retailer in the world. } \\
\text { Basic values: } \\
\text { - Fire-fuelled-We are fuelled by internal fire. } \\
\text { - Ambition-driven-Ambition drives us in action. } \\
\text { - Socially-responsible-We are responsible for what we do. } \\
\text { - Team-oriented-As a team we are the greatest strength. } \\
\end{array}$ \\
\hline
\end{tabular}




\begin{tabular}{|c|c|}
\hline & Mission and vision statements. Values \\
\hline $\begin{array}{l}\text { Polpharma } \\
\text { Group }\end{array}$ & $\begin{array}{l}\text { Mission } \\
\text { "We care". } \\
\text { In everything we do, we keep patients in mind, supporting them in health and treating them } \\
\text { in illness. Every day, we support doctors, nurses and pharmacists in caring for patients. } \\
\text { In our activities, we are guided by the motto "People helping people". Corporate Social } \\
\text { Responsibility is an integral part of our daily activities. } \\
\text { Basic values } \\
\text { - respect } \\
\text { - integrity } \\
\text { - responsibility } \\
\text { - solidarity } \\
\text { - cooperation }\end{array}$ \\
\hline Podravka & $\begin{array}{l}\text { Vision } \\
\text { Dedicated to improvement of everyday, quality of life for our consumers, customers and } \\
\text { employees by being innovative and international. } \\
\text { Mission } \\
\text { Providing innovative culinary experiences and healthy living solutions. } \\
\text { Basic values } \\
\text { Our basic values are: } \\
\text { - creativity-ideas that move the heart, because the heart moves everything else; } \\
\text { - trust-as a stock of every good meal; } \\
\text { - passion - what turns a meal into a feast; } \\
\text { - consumer trust-we do not have consumers, we have guests at our table, and to every- } \\
\text { thing, we do we add excellence. }\end{array}$ \\
\hline $\begin{array}{l}\text { Atlantic } \\
\text { Group }\end{array}$ & $\begin{array}{l}\text { Vison } \\
\text { The Atlantic Group's vision is to be a modern, innovative and efficient company that produces } \\
\text { and distributes high-quality consumer goods, contributing to the quality lives of consumers. } \\
\text { Mission } \\
\text { The Atlantic Group's mission is to build and maintain long-term relationships with customers } \\
\text { and consumers by offering them unique products and services tailored to their individual } \\
\text { needs. The Atlantic Group creates added value by developing new products, constant innova- } \\
\text { tion, recognising new business opportunities and setting market trends, while recognising } \\
\text { and developing human potential. } \\
\text { Basic values } \\
\text { - growth: we create a new value-because we always strive for progress, we never lose our } \\
\text { appetite for steady and stable growth. We are coming out of our comfort zone, always } \\
\text { hungry for new challenges, we strive to grow our brands, markets and profits, as well as } \\
\text { the development of our employees' potential. } \\
\text { - passion: we create with enthusiasm-it is not just a matter of what we do, but the way we } \\
\text { do it. Alike a special spice, the passion with which we refine our work makes a difference } \\
\text { and helps to achieve better results. Commitment is the secret ingredient that makes our } \\
\text { products better and the future brighter. } \\
\text { - care: we are creating a better environment-we are an organisation that cares about each } \\
\text { other, for the well-being of our colleagues, nurturing business relationships and caring } \\
\text { about what kind of world we leave to future generations. } \\
\text { - openness: we create a better open mind-whatever we do, we never cease to be curious, } \\
\text { always fearless (and learn from mistakes!), and thirsty for fresh ideas and new experi- } \\
\text { ences. We accept a variety of approaches and different opinions knowing that they will } \\
\text { lead us to better solutions for everyday tasks and challenges. }\end{array}$ \\
\hline
\end{tabular}




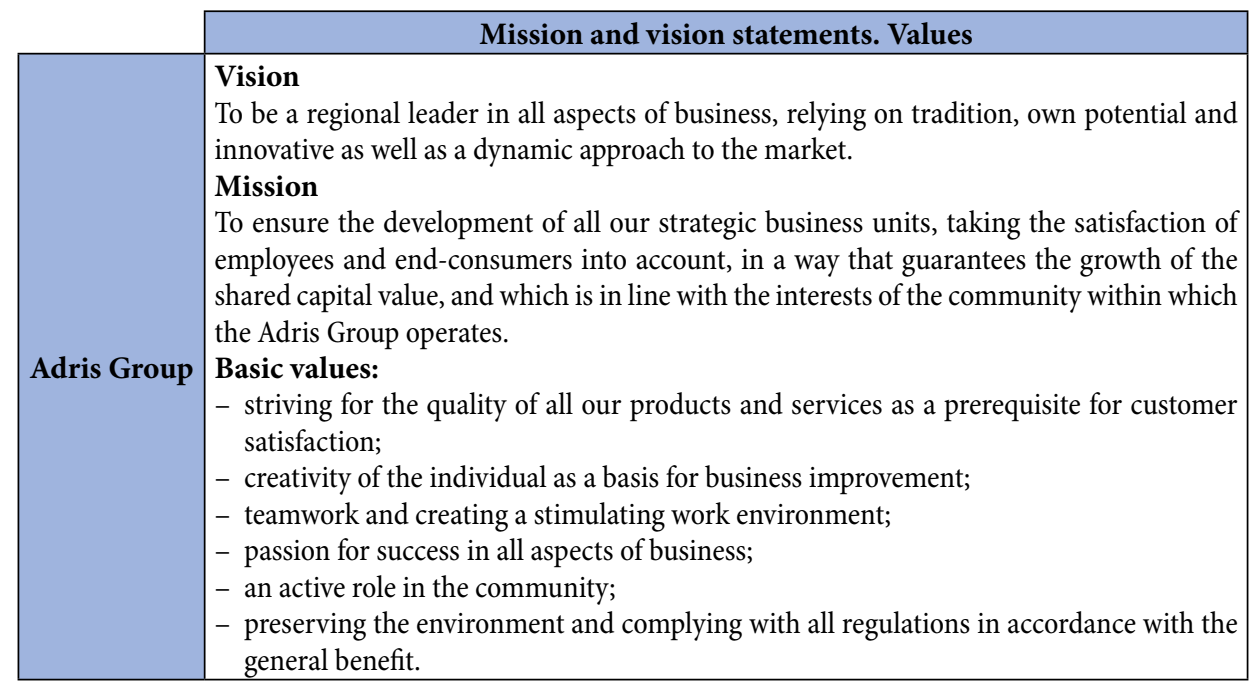

Source: Own elaboration based on (Cyfrowy Polsat, n.d.; LPP, n.d.; Polpharma, 2020; Podravka, 2020; Atlantic Grupa, 2006, 2019; Adris, n.d.).

\subsection{Incorporating sustainable development into corporate objectives}

The mission and vision of any organisation should find expression in the company's goals. The goals are used to specify in which direction a company wants to develop. Subjectively or objectively, the defined goals are:

- understood as the future, desired state or result of the organisation's operation;

- possible and planned to be achieved within the time frame or period falling within the time range covered by the multi-annual or short-term action plan (...).

"The goals of the enterprise are certain distinguished and/or desired states and processes to be achieved by the enterprise in the course of its operations" (Krzakiewicz \& Cyfert, 2006, p. 16). Typically, such goals are: profit, company value, growth, liquidity, management goals (e.g. sales volume), added value, ambitious goals or simply creating a workplace (Noga, 2009, p. 65).

In Table 2, there are some examples of companies' strategic goals.

Table 2. Sample goals of the companies from the Forbes ranking

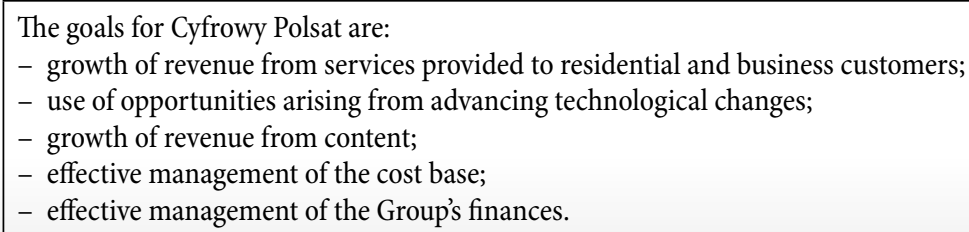


The Dino Group's strategy calls for continued growth by focusing on 3 key areas:

- continuation of rapid organic growth in the number of stores;

- continued growth in LFL sales revenue in the existing store network;

- consistent improvement of profitability.

On the other hand, the strategic goal of the Maspex Group is formulated as:

- a constant organic growth and the implementation of acquisitions that may expand the portfolio of the company.

In its strategic plan, Podravka emphasizes its role in the development of agriculture in the Republic of Croatia, by providing its subcontractors with security in production and by monitoring the quality of the entire process from planting to safe purchase. The continuous aim of Podravka is to achieve synergestic effects by strengthening primary domestic production. In the strategic plan for the period from 2018 to 2022, the following goals are stated regarding this role:

- to significantly increase in the number of vegetable crops and fruits, both in development of experimental fields and in own production;

- to develop stronger connections with domestic subcontractors;

- to increase the share of domestic fruit of production to 90 percent;

- to increase the share of domestic vegetables, especially tomatoes, peppers, beans, dried root vegetables and cereals to 100 percent.

Another aspect emphasized in Podravka is preserving health and contributing to the change of bad eating habits of modern citizens. Therefore, Podravka developed the Nutritional Strategy as a subsection of the business strategy. In this section, the following goals are stated:

- reducing the content of saturated and trans fatty acids, salt (sodium) and sugar in products;

- optimising products with nutrients that ensure health well-being;

- in the development of new products, focusing on children, the elderly population, consumers with special dietary needs, supporting the health of the digestive system, support in achieving and maintaining a healthy body weight and healthy lifestyle;

- providing consumers with accurate and valuable information about our products through packaging and promotional activities;

- educating and pointing to the importance of nutritional value of meals and serving sizes.

Source: (Maspex, n.d.; Cyfrowy Polsat, n.d.; Dino. Najbliżej Ciebie, 2020; Agrobiz, 2018; Lider, 2018).

The proposed goals, in the event of questioning the principle of profit maximisation, lead to their different definition, e.g.: satisfactory profit, maximising sales volume, market share, survival, maximising utility in relation to managers, Corporate Social Responsibility and enterprise growth (Noga, 2009, p. 114).

Concluding, the mission and vision statements are translated into strategic goals of different types. Traditionally, economic goals are the main ones, while social goals subordinate them.

To sum up what we have observed in 21 st century, there is a strong trend towards including the SD concept into the organisation's strategy. There is strong pressure from stakeholders to change models of business to ones more ecological, ethically oriented and to do business in a way more accepted by societies. To make it more reliable-they have to be translated into business strategies-starting from goals, and then by choosing a combination of tools and technics which are in agreement with SDG-usually in the form of the Corporate Social Responsibility strategy (CSR). Integrating business goals with CSR still becomes a challenge, but it seems to be unavoidable in the next years. 


\subsection{Integrating corporate strategy with social development and Corporate Social Responsibility}

The companies and examples discussed in previous chapters are strongly connected with SD or CSR, and many companies implement and follow SD or CSR values. However, it is often limited to selected aspects. The SD or CSR goals and corporate objectives or functional strategies are usually integrated on some level or in selected areas of business. What companies need is to include the CSR and $\mathrm{SD}$ concept into their integrated strategy by following some types of strategies and models.

The degree of SD and CSR integration corresponds to the following strategies (Bertezene \& Vallat, 2014):

- the reactive strategy refuses most or all kinds of CSR, and then does not implement what the stakeholders expect;

- the defensive strategy accepts the idea of some CSRs, but defines and implements only the minimum of what stakeholders expect (selected activities);

- the accommodating strategy integrates CSR and tries to implement what the stakeholders expect (this is the case of total CSR and the hybrid one);

- the proactive strategy anticipates the requirements and expectations of the stakeholders, defining objectives and implementing actions going beyond what stakeholders require (this is the case of linked and integrated CSR).

One very useful tool in designing strategic sustainability goals is A. Carroll's pyramid, in which 4 types of responsibilities are identified: economic, legal, ethical and philanthropic. To this base, numerous authors add environmental responsibility (Dahlsrud, 2008). According to Carroll's pyramid, in strategic goals, companies should address how they will ensure economic sustainability in the long-run, then how they adjust and address legal requirements regarding internal audience, close external stakeholders (customers and suppliers), towards local community as well as the general public. The stakeholders' approach is not only oriented towards a description of fulfilling legal requirements, but it should also address ethical standards regarding stakeholders, and philanthropic goals describing planned contribution to the local and global society. Ecological responsibility is added as a separate, newer aspect of SD and it suggests that the ecological objectives of a company should be implemented in business strategy as well. Those goals are oriented towards saving, water saving and reuse, waste management, recycling goals, decrease of gas emission and decreasing carbon footprint, etc.

Some authors suggest the application of SMART strategic planning, where "SMART" as an acronym points out that strategic goals should be: specific, measurable, achievable, relevant and time-bound (Bjerke \& Renger, 2017). In Table 3, some examples are shown of SD goals which are developed in accordance to Carroll's extended pyramid. 


\section{Table 3. Setting goals and targets in organisations based on Carrolls' pyramid}

\begin{tabular}{|c|c|c|}
\hline Dimensions & Possible goals & $\begin{array}{c}\begin{array}{c}\text { Selected examples of measurable solutions applied } \\
\text { by organisations }\end{array} \\
\end{array}$ \\
\hline Economic & $\begin{array}{l}\text { Continuous growth of a mar- } \\
\text { ket share/revenues/profits; } \\
\text { Ensuring solvency and liquid- } \\
\text { ity in the long-run; } \\
\text { Achieving standard business } \\
\text { goals and increasing business } \\
\text { performance, but from a long- } \\
\text { term perspective! }\end{array}$ & $\begin{array}{l}\text { - in the next } 5 \text { years, an increase market share by } 5 \% \text {; } \\
\text { - in the next } 20 \text { years, an increase revenues/profits by } 30 \% \text {; } \\
\text { - decrease ratio of long-term credits and loans in overall } \\
\text { expenses by } 5 \% \text {. }\end{array}$ \\
\hline Legal & $\begin{array}{l}\text { Conformity to legal standards } \\
\text { on the market of operation; } \\
\text { Being a proactive partner in } \\
\text { professional associations by } \\
\text { discussing and improving the } \\
\text { legal framework in the field of } \\
\text { workers' rights, health, safety, } \\
\text { environment protection, mar- } \\
\text { ket protection; etc. }\end{array}$ & $\begin{array}{l}\text { - in the next year-participating in } 5 \text { educational actions } \\
\text { regarding consumer protection organised by Univer- } \\
\text { sities or Chambers of Economy or by Associations for } \\
\text { consumer protection; } \\
\text { - becoming a member of } 3 \text { professional associations on } \\
\text { local and regional levels in the field of interest, actively } \\
\text { contributing to their work and actively promoting SD } \\
\text { practices; } \\
\text { - continuous, active participation in public debates re- } \\
\text { garding workers' rights (or some other topic of SD). }\end{array}$ \\
\hline Ethical & $\begin{array}{l}\text { Promoting high ethical stand- } \\
\text { ards towards internal and ex- } \\
\text { ternal stakeholders; } \\
\text { Perceiving and treating suppli- } \\
\text { ers/customers/buyers as long- } \\
\text { term partners; } \\
\text { Striving to enhance long-term } \\
\text { loyalty of employees. }\end{array}$ & $\begin{array}{l}\text { - organisation of annual events for long-term suppliers; } \\
\text { - loyal consumers/buyers are rewarded with an annual } \\
\text { discount of } 2 \% \text {; } \\
\text { - each } 3 \text { years, employees are granted an additional bonus } \\
\text { of } 3 \% \text { of their annual salary; } \\
\text { - every } 5 \text { years, employee may go on a 3-day family vaca- } \\
\text { tion at the expense of the company; } \\
\text { - increasing purchases from local suppliers by } 15 \% \text {. }\end{array}$ \\
\hline Philanthropic & $\begin{array}{l}\text { Contributing to local commu- } \\
\text { nity development by support- } \\
\text { ing local sports, culture, sci- } \\
\text { ence, humanitarian work and } \\
\text { the work of NGO (in financial } \\
\text { and other resources). }\end{array}$ & $\begin{array}{l}\text { - food manufacturer decides to donate } 0.5 \% \text { of produced } \\
\text { food to local social supermarket, food bank or soup } \\
\text { kitchen; } \\
\text { - supporting local handball teams with } 10.000 \text { EUR per year; } \\
\text { - buying equipment for } 3 \text { playgrounds in the next } 3 \text { years; } \\
\text { - playing an active part in improving health-wellbeing in } \\
\text { the local community by reducing sugar in products by } \\
5 \% \text { and saturated fat by } 10 \% \text { by } 2022 \text {. }\end{array}$ \\
\hline Environmental & $\begin{array}{l}\text { Saving energy, improving wa- } \\
\text { ter management, decreasing } \\
\text { gas emission, implementing } \\
\text { waste management solutions, } \\
\text { increasing recycling, decreas- } \\
\text { ing carbon footprint, etc. }\end{array}$ & $\begin{array}{l}\text { - by } 2025 \text {, reducing the usage of diesel cars in the fleet } \\
\text { by } 20 \% \text {; } \\
\text { - in the next } 5 \text { years, fully switching to the machines with } \\
\text { the highest energy efficiency available on the market; } \\
\text { - increasing investments in water cleaning solutions by } 25 \% \text {; } \\
\text { - in cooperation with suppliers, implementing } 100 \% \text { re- } \\
\text { cyclable packaging in supply chains by } 2025 \text {; } \\
\text { - in the next } 2 \text { years, digitalising all business documents } \\
\text { and communication regarding procurement (this can } \\
\text { decrease the overall paper usage at a company by more } \\
\text { than } 30 \% \text { ). }\end{array}$ \\
\hline
\end{tabular}




\subsection{Sustainable development at a functional level of organisations}

The model of integrating economic values with social values underlined in CSR was developed, among others, by Porter and Kramer (Porter \& Kramer, 2006, p. 8; Porter \& Kramer, 2011). They developed a model of the value added chain, enriched by social value (added to economic). According to them, there is a balanced coexistence in which enterprises require society and society requires enterprises. The chain of value is comprised of processes within the enterprise, but is also co-created by all stakeholders. In a classic chain of creating value by an enterprise one can distinguish primary and support functions performed in the enterprise. The primary functions include: inbound and outbound logistics, marketing and sales, and service activities, the support ones embrace: managing finances, managing human resources, procurement and technology development. Unique abilities in the field of managing resources and also competences and unique skills, make it possible to make an enterprise offer so distinct that the risk of competitors copycatting the solutions is minimised. What is more, in such a presented chain of value, each sphere offers a possibility to implement solutions characteristic of SD. Table 3. shows SD examples of initiatives undertaken within the particular functions of the enterprise.

As a result a company that has decided to build corporate economic and social value in accordance with the idea of sustainable development translates it into functional strategies. For managers, usually CSR is a guideline in developing a company's strategy in relation to the sphere of business functions (Figure 1).

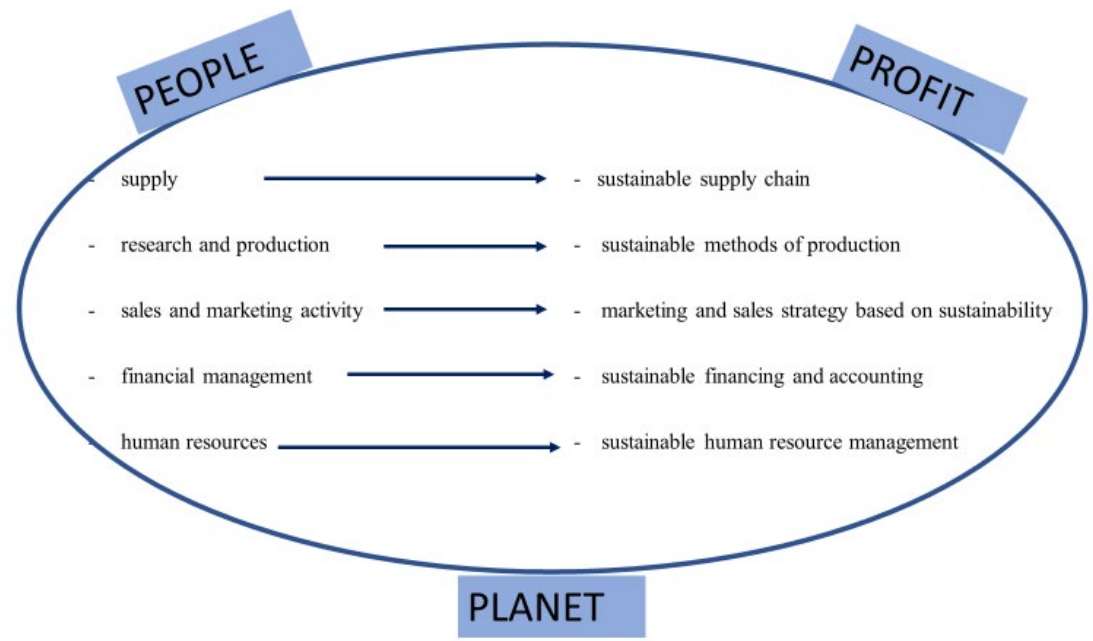

Figure 1. 3P model and business functions

Source: Own elaboration. 
Table 4 includes examples how SD goals can be implemented by organizations in their functional areas.

\section{Table 4. The role of SD in particular spheres of the added social and economic value chain}

\begin{tabular}{|c|c|}
\hline SD enhanced area & Sample strategic goals \\
\hline $\begin{array}{l}\text { Financial manage- } \\
\text { ment } \\
\text { Practices of reporting } \\
\text { on CSR } \\
\text { Transparency } \\
\text { Using lobbying } \\
\text { Practices of corporate } \\
\text { governance }\end{array}$ & $\begin{array}{l}\text { Respecting deadlines of payments to suppliers, employees } \\
\text { Gaining financial support from investors seeking stable investments } \\
\text { Increasing the share of innovative sustainable investments in corporate portfolio } \\
\text { Responsible financial and nonfinancial reporting }\end{array}$ \\
\hline $\begin{array}{l}\text { Human resources } \\
\text { management } \\
\text { Recruitment } \\
\text { Diversity } \\
\text { Equality } \\
\text { Education and training } \\
\text { Work safety } \\
\text { Medical care } \\
\text { Whistleblowing policy } \\
\text { Code of conduct }\end{array}$ & $\begin{array}{l}\text { Place of work: } \\
\text { Transparent recruitment procedures } \\
\text { Prevention and safety requirements } \\
\text { Training and inclusion in awareness-raising programs among employees about } \\
\text { potential threats and safety goals } \\
\text { Medical care } \\
\text { Implementation and continuation of accident reduction programs at work } \\
\text { Communication and employee involvement: } \\
\text { Implementation of instruments and procedures for dialogue with employees } \\
\text { and consistent correction of activities (research of the work atmosphere among } \\
\text { employees, communication downstream, group interviews, etc.) } \\
\text { Improvement and extension of the scope of application of internal communica- } \\
\text { tion tools } \\
\text { Making employees aware of the goals of the organization. Achieving the "working } \\
\text { climate" index at the designated level } \\
\text { Career path and skills development: } \\
\text { Strengthening the learning process within the organization and sharing knowl- } \\
\text { edge } \\
\text { Support for the process of generating technological and organizational innova- } \\
\text { tions to improve processes } \\
\text { Promotion of the development of managerial skills necessary to function in } \\
\text { a competitive environment } \\
\text { Development of individual career paths }\end{array}$ \\
\hline $\begin{array}{l}\text { Procurement } \\
\text { Timely payments } \\
\text { Training for suppliers } \\
\text { Diversity of suppliers } \\
\text { Replacement of specific } \\
\text { components } \\
\text { Code of conduct }\end{array}$ & $\begin{array}{l}\text { Training for suppliers } \\
\text { Supporting local suppliers } \\
\text { Developing sales channels for suppliers } \\
\text { Respecting commercial network's internal requirements }\end{array}$ \\
\hline
\end{tabular}




\begin{tabular}{|c|c|}
\hline SD enhanced area & Sample strategic goals \\
\hline $\begin{array}{l}\text { Technology develop- } \\
\text { ment } \\
\text { Relations with universi- } \\
\text { ties and research centres } \\
\text { Product safety } \\
\text { Developing research } \\
\text { methods }\end{array}$ & $\begin{array}{l}\text { Analyses of the product's impact on the natural environment } \\
\text { Decreasing usage of conventional sources of energy } \\
\text { Reduce your environmental impact by doubling your energy consumption from } \\
\text { renewable resources by } 2025 \\
\text { Circular production } \\
\text { Increase in energy production through the use of renewable resources in cogen- } \\
\text { eration by } 30 \% \\
\text { Reduction in the amount of waste disposed of in landfills (by } 18 \% \text { in } 2025 \text { ) } \\
\text { Development of the waste sorting system ( } 60 \% \text { in } 2025 \text { ) } \\
\text { Promoting certified quality, safety and environmental management systems. } \\
\text { Increasing the share of renewable sources of energy to } 80 \% \text { in } 2025\end{array}$ \\
\hline $\begin{array}{l}\text { Inbound and } \\
\text { outbound logistics } \\
\text { operations } \\
\text { Limiting the number of } \\
\text { collective packages } \\
\text { Recycling } \\
\text { Streamlining transport } \\
\text { to protect the } \\
\text { environment }\end{array}$ & $\begin{array}{l}\text { Optimization of logistics by networks } \\
\text { Green transportation } \\
\text { Green fuel } \\
\text { Efficient order processing Facilitating communication Introducing innovation } \\
\text { to streamline business processes Code of conduct }\end{array}$ \\
\hline $\begin{array}{l}\text { Marketing and sales } \\
\text { Ethical advertising } \\
\text { Sales promotions } \\
\text { Fair handling of } \\
\text { complaints } \\
\text { Dialogue with customers } \\
\text { Charity }\end{array}$ & $\begin{array}{l}\text { 6P-These are often defined among others in the codes of ethics } \\
\text { Sustainable packaging } \\
\text { Ethical values in brand core } \\
\text { Fair pricing } \\
\text { Ethical communication } \\
\text { Sustainable sources of energy in stores } \\
\text { Location of the business in regions to improve quality of life and access to ed- } \\
\text { ucation, products }\end{array}$ \\
\hline
\end{tabular}

Source: Own work based on (Porter, 1992).

It's necessary to add in that place, that although the Porter and Kramer's model is well known, it's also criticize for few reasons (Beschorner \& Hajduk, 2017; Crane, Palazzo, Spence, \& Matten, 2014, Sarpal, Teck, \& Fong 2013). For example it is highly doubtful that the tensions between business goals and social and environmental goals can create both public and private value simultaneously. In order to do so, it would require the investment of corporate resources with uncertain and 'distant payoff'. Another point is, that organizations are obligated to build value for shareholders and social goal investments, if not profitable or not enough profitable. Maybe the reason is that owners blame managers for poor business decisions and losses for shareholders. Next, CSR must be integrated within the firm's value chain. But since no firms have infinite resources and therefore, they should carefully and strategically select the specific area of value chain that they wish to integrate CSR and gain sustainable competitive advantage. Porter and Kramer's model provides very little guidance on how a firm should precisely decide which value chain (stage of it) exactly that precious resource should be set on. According to Weitzner and 
Darroch (2009) that approach to CSR fails in providing guidance on the boundaries of ethical behaviour for corporations, as well that it does address on how to develop ethical activities into meaningful value chain social impacts. Hence Weitzer and Darroch stated, that Porter's value chain model lacks an ethical core and limits the prospective development for ethical initiatives as compared to the virtue-based approach to ethical positioning.

At the end, it should be emphasized that the role of managers in the implementation of strategies based on the CSR concept is crucial-they decide its choice as the direction of the company's development and implementation (Hemingway \& Maclagan, 2004, pp. 33-44). However, there is great number of valuable initiatives from employees who often voluntarily dedicate their time and resources to implementing social goals at the organisation for which they work. As a result, social capital is developed, which further has positive effects on human relations and management processes.

The SDGs are a guide for companies on how they can align their strategies as well as measure and manage their contribution to them (GRI, UN Global Compact, WBCSD, 2015). Thus, the idea of sustainable development has to be reflected in strategic, tactical and operational decisions. Goal setting is critical in business success, helping to foster shared priorities and better performance across the organisation. By aligning company goals with the SDGs, the leadership can demonstrate its commitment to sustainable development. Directions of the development set up at the top management level are translated into goals at lower levels-in SBU and in the organisation's functional areas.

The SDG's aim is to redirect global public and private investment flows towards the challenges they represent. In doing so, they define growing markets for companies that can deliver innovative solutions and transformative change.

Whilst the business case for corporate sustainability is already well-established, the SDGs may, for example, strengthen the economic incentives for companies to use resources more efficiently, or to switch to more sustainable alternatives, as externalities become increasingly internalised.

\section{Questions / tasks}

1. Explain the relationship between SD and CSR.

2. Please, provide the mission and vision of sustainable organisation for the chosen examples. What would their goals be?

a) Retail sector;

b) Manufacturer of artificial fertilizers; 

c) University education;
d) Manufacturer of organic food;
e) Manufacturer of ethical products.

3. Go to websites of organisations, the missions, visions and also values of which are presented in Table 1. What kind of activities would you expect in their reports or websites to convince you. Please, check this.

4. When talking about corporate responsibility, consider the following on a chosen example from your country:

- what type of responsibility is taken by employees and what by managers and owners?

- to whom or whose liability should be considered?

- what is the source of responsibility?

5. Find the ranking of the best SD companies in your country. How is the idea of SD and/or CSR included in their strategy (mission, vision, goals)? Please, compare with other leading companies in your country.

6. What does it mean to take economic responsibility? Use A. Carroll's model to discuss.

7. What does it mean to take legal responsibility? Use A. Carroll's model to discuss.

8. Promises or truth. Prepare a critical analysis regarding mission and vision statements of selected companies.

9. How do we integrate the SD strategy into corporate strategy, SBUs and functional strategies in the case of companies which operate in sectors:

- retailing fast-fashion sector;

- tourist sector;

- IT sector;

- automobile sector;

- energy sector.

10. Is the criticism of Porter's and Kramer's added social and economic shared value chain justified?

11. Check on websites what B-Corps are. What kind of business model is it? Is it the solution to the dilemma between social and economic goals? Find examples of B-Corps in your own country. https://bcorporation.net/

\section{References}

Adris. (n.d.). Adris-the past and the present. Retrieved October 10, 2020 from https://www.adris. $\mathrm{hr} / \mathrm{o}$-nama/adris-nekad-i-danas/

Agrobiz. (2018, August 18). Strateški je cilj Podravke do 2022. ostvariti 100\% udio domaćih sirovina u gotovom proizvodu. Retrieved from https://www.agrobiz.hr/agrovijesti/strateski-je-cilj-podravke-do-2022-ostvariti-100-udio-domacih-sirovina-u-gotovom-proizvodu-10165 
Atlantic Grupa. (2006). Prospekt. Retrieved October 7, 2020 from https://www.atlanticgrupa.com/ media/uploads/documents/atgr-o-11ca-prospekt.pdf

Atlantic Grupa. (2019). Godišnje Izvješće. Retrieved October 7, 2020 from https://www.atlanticgrupa. $\mathrm{com} / \mathrm{media} /$ files/fileitem/G/Godisnje-izvjesce-za-2019g/Godisnje\%20izvjesce\%20Atlantic\%20 Grupe\%20za\%202019.godinu.pdf

Bertezene, S., \& Vallat, D. (2014). An overview of the main strategies and approaches to CSR. International Conference on Quality and Service Science. August 28-29. Liverpool. Retrieved November 10, 2002 from file://C:/Users/48691/AppData/Local/Temp/An_overview_of_the_main_strategies_and_a.pdf

Beschorner, T., \& Hajduk, T. (2017). Creating shared value. A fundamental critique. In Method and morals in constitutional economics (pp. 27-37). https://doi.org/10.1007/978-3-319-48802-8_3

Bjerke, M. B., \& Renger, R. (2017). Being smart about writing SMART objectives. Evaluation and Program Planning, 61(April), 125-127.

Bowen, S. (2018). Mission and vision. In R. L. Heath, W. Johansen, J. Falkheimer, K. Hallahan, J. J. C. Raupp, \& B. Steyn (Eds.), The international encyclopedia of strategic communication (pp. 1-9). John Wiley \& Sons. https://doi.org/10.1002/9781119010722.iesc0111

CD Projekt (n.d.). [Corporate website]. Retrieved from https://www.cdprojekt.com/en

Crane, A., Palazzo, G., Spence, L., \& Matten, D. (2014). Contesting the value of the shared value concept. California Management Review, 56(2), 130-153.

Croatia.eu. land and people. (n.d.). The economy. Major companies. The largest private companies. Retrieved from https://croatia.eu/index.php?view=article\&id=33\&lang=2

Cyfrowy Polsat. (n.d.). [Corporate website]. Retrieved from https://grupapolsat.pl/en

Dahlsrud, A. (2008). How Corporate Social Responsibility is defined: an analysis of 37 definitions. Corporate Social Responsibility and Environmental Management, 15(1), 1-13.

Dino. Najbliżej Ciebie. (2020, October 2). [Corporate website]. Retrieved from https://grupadino.pl/en GRI, UN Global Compact, WBCSD. (2015). SDG compass. The guide for business action on the SDGs. Retrieved from https://sdgcompass.org/wp-content/uploads/2016/05/019104_SDG_Compass_Guide_2015_v29.pdf

Hemingway, C. A., \& Maclagan, P. W. (2004). Managers' personal values as drivers of Corporate Social Responsibility. Journal of Business Ethics, 50(1), 33-44. https://doi.org/10.1023/ B:BUSI.0000020964.80208.c9

Krzakiewicz, K., \& Cyfert, S. (2006) Organizacja i zarządzanie. Przegląd podstawowych pojęć. In K. Krzakiewicz (Ed.), Teoretyczne podstawy organizacji i zarzadzania. Poznań: Wydawnictwo Akademii Ekonomicznej w Poznaniu.

Lider. (2018, January 3). Marin Pucar: Strateški nam je cilj povećati udjel domaćih sirovina. Retrieved November 11, 2020 from https://lider.media/aktualno/marin-pucar-strateski-nam-je-cilj-povecati-udjel-domacih-sirovina-32794

LPP SA-Polish clothing company. (n.d.). [Corporate website]. Retrieved from https://www.lppsa. com/en

Maspex. (n.d.). Maspex Group. Retrieved from https://en.maspex.com/maspex,maspex-group,3.html Noga, A. (2009). Teorie przedsiębiorstw. Warszawa: PWE.

Podravka. (2020, October 5). About Podravka. Retrieved from https://www.podravka.com/about/ Podravka. (2020, October 6). Responsibility. Retrieved from https://www.podravka.com/responsibility/ Polpharma. (2020, October 2). [Corporate website]. Retrieved from https://polpharma.pl/en/ Porter, M. (1992). Strategia konkurencji. Warszawa: PWE.

Porter, M., \& Kramer, P. (2006). Strategy and society: The link between competitive advantage and Corporate Social Responsibility. Harvard Business Review, 84(12), 78-92. 


\section{5.}

Magdalena Stefańska, Blaženka Knežević

Porter, M. E., \& Kramer, M. R. (2011). Creating shared value. Harvard Business Review, 89(1), 2-17. Santander. (n.d.). Corporate Social Responsibility. Retrieved from https://www.santander.pl/en/about-santander/corporate-social-responsibility-csr

Sarpal, R., Teck, T. S., \& Fong, Y. S. (2013). A critical review on porter's integrated approach towards Corporate Social Responsibility. International Journal of Business and Management Tomorrow, 3(8), 1-5.

Szeligowski, M. (2019, October 31). Ranking „Forbesa”. Top 10 największych polskich firm prywatnych. Retrieved from https://spidersweb.pl/bizblog/forbes-dziesiec-polskich-firm-2019/

Weitzner, D., \& Darroch, J. (2009). A comprehensive framework for strategic CSR: Ethical positioning and strategic activities. Academy of Management Annual Meeting Proceedings, 6(6), 1-6.

van Tulder, R., van Wijk, J., \& Kolk, A. (2009). From chain liability to chain responsibility MNE approaches to implement safety and health codes in international supply chains. Journal of Business Ethics, 85, 399-412. 


\section{PART

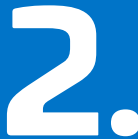

SUSTAINABLE DEVELOPMENT AND CORPORATE

SOCIAL RESPONSIBILITY IN MANAGEMENT 



\title{
1.
}

\section{SUSTAINABLE DEVELOPMENT IN CORPORATE STRATEGY}

\author{
Blaženka Knežević \\ Faculty of Economics and Business, University of Zagreb \\ Petra Škrobot \\ Faculty of Economics and Business, University of Zagreb
}

\begin{abstract}
The aim of the chapter is to explain how to incorporate Sustainable Development Goals (SDGs) into corporate strategy in order to increase the competitive advantage of a company in the long-run. The questions how to set a mission, vision and objectives to prepare annual reports in the field of sustainability will be discussed. Furthermore, motives as to why companies have to consider local and global perspective when setting SD objectives and the problem of conflicts in SD goals will be determined.
\end{abstract}

Keywords: mission, objectives, SDG, strategic goals, vision. 


\subsection{Setting corporate mission and vision in accordance with Sustainable Development Goals}

At the beginning of this millennium, the United Nations set Millennium Development Goals to be achieved by 2015 (www.unesco.org). These are to: (1) eradicate extreme poverty and hunger, (2) achieve universal primary education, (3) promote gender equality and empower women, (4) reduce child mortality, (5) improve maternal health, (5) combat HIV/AIDS, malaria and other diseases, (7) ensure environmental sustainability and (8) global partnership for development. At the United Nation's Rio +20 summit in 2012, those goals were broadened, and now, the United Nation's proclaim 17 Sustainable Development Goals (SDGs) to be achieved by 2030 (UN SD Agenda 2030). SDGs are set in 3 dimensions of sustainable development: those social, economic and environmental, taking aspects related to peace, justice and effective institutions into account (UN, 2021b).

The UN SDGs comprise updated MDGs in areas of poverty and hunger, education, health, environmental sustainability and global partnership, but they introduce some new aspects in areas of material usage, clean air, nutrient cycles, hydrological cycles, ecosystem services, biodiversity and climate stability (Griggs, 2013). All 17 UN SDGs are outlined and explained in other chapters.

After elaborating human impact on environment in the so-called Anthropocene geological epoch, and based on UN SDGs, Griggs (2013) summarises 6 basic types of sustainability goals, both for governmental and profit organisations:

1. Thriving lives and livelihoods (ending poverty; promoting well-being: education employment, information access, housing, health services; reducing inequalities; moving towards sustainable consumption and production);

2. Sustainable food security (ending hunger; ensuring better nutrition; sustainable systems of food production, distribution and consumption);

3. Sustainable water security (ensuring universal access to clean water; enabling basic sanitation; implementing efficient water management);

4. Universal clean energy (providing affordable access to clean energy; minimising local pollution and detrimental impact on health; mitigating global warming);

5. Healthy and productive ecosystems (maintaining biodiversity; implementing efficient eco-service management; valuating, measuring, conserving and restoring natural resources);

6. Governance of sustainable societies (transforming all institutions and governance to address all previously stated 5 goals; developing national monitoring, reporting and verification systems for sustainable development issues; ensuring open access to information and decision-making processes at all levels).

The given framework can be a useful tool in setting corporate sustainable development strategies, because it provides key areas and keywords that can be used 
to express the mission and vision of a company with regard to sustainability topics. In Table 1, some examples of mission and vision statements are developed in accordance to SDGs.

\section{Table 1. Incorporating SDGs into corporate mission and vision (some illustrative examples)}

\begin{tabular}{|c|c|c|}
\hline $\mathrm{Nr}$ & Goal type & Mission, vision or strategic objective statements \\
\hline 1 & $\begin{array}{l}\text { Thriving } \\
\text { lives and } \\
\text { livelihoods }\end{array}$ & $\begin{array}{l}\text { Food manufacturing company: } \\
\text { "The mission of our company is to promote the highest ecological standards in our } \\
\text { logistic chain, starting from harvesting to the table of our consumers" (this statement } \\
\text { is oriented towards sustainable production and distribution). } \\
\text { Tourist company: } \\
\text { "By employing local community members, we want to promote and develop highly } \\
\text { harmonised living standards on islands as a specific and vital part of our country" (this } \\
\text { statement is oriented towards ending poverty, reducing inequalities and promoting } \\
\text { well-being in the local community). } \\
\text { Telecommunication operator: } \\
\text { "Maintaining the highest level of service and all regions covered with the best network } \\
\text { capacities possible is our ultimate strategic goal" (this statement is oriented towards } \\
\text { reducing inequalities and promoting well-being by offering identical information } \\
\text { access to all users, no matter if they live in urban or rural areas). }\end{array}$ \\
\hline 2 & $\begin{array}{l}\text { Sustainable } \\
\text { food security }\end{array}$ & $\begin{array}{l}\text { Food manufacturing company: } \\
\text { "We contribute to national health by continuous improvements in nutritive values of } \\
\text { our products". } \\
\text { "Reducing sugar and saturated fats, usage of ingredients with a high level of protein and } \\
\text { fibres are a must!" (both statements are accordance with the goal of implementing } \\
\text { better nutrition). } \\
\text { "Our vision is to feed hungry people! All food that we produce is efficiently distributed } \\
\text { to our consumers and we strive to serve people in need by donating all surpluses in } \\
\text { a timely manner!" (statement is given in accordance with the goal of sustainable } \\
\text { food production and distribution, but also the 'ending hunger' goal). }\end{array}$ \\
\hline 3. & $\begin{array}{l}\text { Sustainable } \\
\text { water } \\
\text { security }\end{array}$ & $\begin{array}{l}\text { Beverage producer: } \\
\text { "Water management is a critical part of our business success, we strive to implement } \\
\text { water saving practices and are continuously improving water disposal practices!" (ad- } \\
\text { dressing goal-implementation of efficient water management). } \\
\text { Hotel chain: } \\
\text { "Recycling water whenever possible!" (addressing goals of preserving clean water } \\
\text { and efficient water management). } \\
\text { Maritime transport company: } \\
\text { "Preservation of natural resources is in focus when dealing with ballast water, each and } \\
\text { every time, with no exceptions!" (addressing goals of preserving clean water and } \\
\text { efficient water management). }\end{array}$ \\
\hline 4. & $\begin{array}{l}\text { Universal } \\
\text { clean energy }\end{array}$ & $\begin{array}{l}\text { Retail company: } \\
\text { "In our space design, we implement low-energy consumption lighting and low energy } \\
\text { consumption refrigerators" (addressing low-energy impact and global warming). } \\
\text { Car manufacturer: } \\
\text { "In the next } 5 \text { years, our ultimate strategic goal is to develop more efficient hybrid and } \\
\text { electrical vehicles. We have to increase such production by more than 50\%" (addressing } \\
\text { goals of clean energy and air pollution). }\end{array}$ \\
\hline
\end{tabular}




\begin{tabular}{|c|c|l|}
\hline Nr & Goal type & \multicolumn{1}{c|}{ Mission, vision or strategic objective statements } \\
\hline 5. & $\begin{array}{l}\text { Healthy and } \\
\text { productive } \\
\text { ecosystems }\end{array}$ & $\begin{array}{l}\text { Forestry: } \\
\text { "For each stable that we cut, we plant 3 new ones!" (addressing implementation of } \\
\text { efficient eco-service management and restoration of natural resources). } \\
\text { Local farm: } \\
\text { "We strive to preserve local and ancient animal species, and to brew in conditions as } \\
\text { did our grandparents!" (addressing goal of maintaining biodiversity). }\end{array}$ \\
\hline 6. & $\begin{array}{l}\text { Governance } \\
\text { for sustain- } \\
\text { able societies }\end{array}$ & $\begin{array}{l}\text { Note: This goal is oriented towards national and local governments, thus we cannot } \\
\text { provide examples of corporate statements. }\end{array}$ \\
\hline
\end{tabular}

Source: Own elaboration.

Mission and vision statements are basic guidelines for further development of sustainable strategy and its implementation. In addition, they are useful for effective communication of main sustainability attitudes and values with internal and external stakeholders. Nonetheless, based on mission and vision statements, a company should develop basic sustainability principles and set major goals that are achievable and measurable over time. Then, policies and activity plans are designed and resources needed for their implementation into everyday business practice are planned. Epstein and Rejc Buhovac (2014, p. 54) suggest that senior management levels should be committed to sustainability strategy and that corporate executives decide on level of sustainability to be implemented in corporate strategy together with resources needed for its incorporation. In addition, they suggest that there are 3 levels of sustainability issues: (1) general, (2) value chain, and (3) those regarding the competitive dimension. General issues effect everyday activities of a company, but a company cannot influence them. A company can strongly affect sustainability issues occurring in its value chain. While in dealing with the competitive dimension, a company has to take all aspects of "Porter's 5 forces" into consideration to improve or change its sustainability performance.

There are 3 main stages in developing sustainability strategy (see Epstein \& Rejc Buhovac, 2014, pp. 55-57), and each stage requires a different approach, different information and different level of top-management involvement. In Figure 1, stages of incorporating sustainable development into corporate strategy are shown. As a company moves from stage 1 to 3 , regarding the sustainability role in overall corporate strategy, its focus, motivation and values, as well as way of conducting business, changes rapidly. While at stage 1 the company only reacts to external obligations regarding sustainable development, the next 2 stages require an active approach in design, implementation and audit of sustainable development policies. Communication and information sharing on sustainability policies and practices changes as well. At stage 3, communication with all stakeholders is more transparent and more objective than during stage 1 . 
- analysing sustainability standards and regulations

- analysing compliancy with existing standards and regulations

- identifying stakeholders and their expectations

- assessing risks and financial implications of current practices (are there some penalties regarding existing practices?)

- develop and publish environmental policy statement in accordance to exixting standards and regulations,

- applying stakeholders' approach in communication

- establishing systems to plan and deal with sustainability issues

- focus is on: meeting regulatory standards in the field of sustainable development

\section{Managing regulatory} compliance

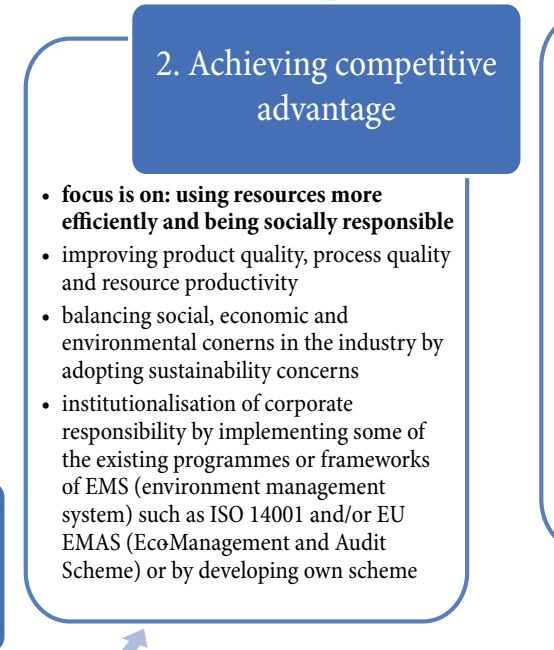

social, environmental and economic issues of sustainable development are fully integrated and implemented in everyday business practice

- corporate sustainability strategy is used to set corporate policies, to change corporate culture and influence managerial decisions at all levels

- company strives to design and innovate products and processes to eliminate waste, reduce negative impact on environment, to make investments into long-term profitability

- transparent reporting on sustainability (usually according to GRI methodology)

- focus is on: the role of sustainability in all processes and decisions

\section{Completing social, economic and} environmental integration

Figure 1. Three stages in sustainability strategy development

Source: Own visualisation according (Epstein \& Rejc Buhovac, 2014, pp. 55-57; Kuisma, 2017, pp. 43-69).

In Table 2, the communication of selected Polish and Croatian companies regarding sustainability is shown. As selected companies are on the lists of most successful companies in observed countries, they can serve as good examples how sustainability policies could be communicated to the wide public and special stakeholders (the selected private Polish companies ranked according to their value in 2019 by Forbes (Szeligowski, 2019); and selected large successful private Croatian companies (Croatia.eu. land and people, n.d.). All analysed companies apply the stakeholder's approach in communicating sustainable development policies, and all of them apply the GRI methodology of sustainable development reporting. GRI compliant reports are available to be downloaded for further analysis.

Table 2. SD in strategy of selected companies

\begin{tabular}{|l|l|}
\cline { 2 - 3 } \multicolumn{1}{c|}{} & \multicolumn{1}{c|}{ Sustainable development communication } \\
\hline Cyfrowy & $\begin{array}{l}\text { Dedicated website in Polish and English language. } \\
\text { Main stakeholders: customers/viewers, employees, natural environment, digital respon- } \\
\text { sibility. } \\
\text { Polsat } \\
\text { of sports. } \\
\text { Reports on SD and CSR are available in accordance to GRI methodology. }\end{array}$ \\
\hline
\end{tabular}




\begin{tabular}{|c|c|}
\hline & Sustainable development communication \\
\hline LPP S.A. & $\begin{array}{l}\text { Website dedicated to sustainability in Polish and English language. } \\
\text { SD strategy can be downloaded for 2015-2030 with clearly defined goals. } \\
\text { Stakeholders: divided into } 2 \text { main groups-planet and people. } \\
\text { Social mission: Sustainable fashion, reducing environmental impact and social respon- } \\
\text { sibility - these are the tenets underlying all our planning and decision-making-on both } \\
\text { a macro and global scale. We are committed to acting fair at every single stage, which } \\
\text { our employees, colleagues, business partners and customers appreciate. However, our } \\
\text { priority is to have positive impact on our planet. } \\
\text { Reports on SD and CSR are available fully following GRI requirements. }\end{array}$ \\
\hline $\begin{array}{l}\text { Polpharma } \\
\text { Group }\end{array}$ & $\begin{array}{l}\text { Website dedicated to CSR in Polish and English language. Separate strategy available, de- } \\
\text { veloped according to SDGs. } \\
\text { Main stakeholders: customers (product-oriented), employees, environment, general public. } \\
\text { Social mission: To improve the health and quality of patients' life, we provide access } \\
\text { to important therapies as well as education and preventive care. Through dialogue and } \\
\text { partnership, we respond to the needs of the communities in which we operate. } \\
\text { Reports on SD and CSR are available fully following GRI. }\end{array}$ \\
\hline Podravka & $\begin{array}{l}\text { Dedicated website with detailed information on CSR and SD, both in Croatian and English } \\
\text { versions. } \\
\text { Stakeholders: consumers, employees, environment, society, local Economy. } \\
\text { Social mission: Advancing the application of norms regarding socially responsible } \\
\text { business and compliance of the economy with society's developmental goals and pre- } \\
\text { serving the environment for future generations. According to Podravka, sustainable } \\
\text { development represents a balance of economic priorities, strengthening society and } \\
\text { environmental protection. } \\
\text { Reports on SD and CSR are available in GRI reports since } 2015 \text { to date. }\end{array}$ \\
\hline $\begin{array}{l}\text { Atlantic } \\
\text { Group }\end{array}$ & $\begin{array}{l}\text { Dedicated website with detailed information on CSR and SD, both in Croatian and English } \\
\text { versions. } \\
\text { Stakeholders: employees, community, environment, investors (covered in CSR part of the } \\
\text { website), but consumers are also stakeholders (emphasized, yet in business strategy and in } \\
\text { the numerous general parts of the website in terms of responsibility towards them). } \\
\text { Social mission: } \\
\text { As a part of the community in which it functions, Atlantic Group is aware of the im- } \\
\text { portance and need of its impact on the improvement of social conditions in general, } \\
\text { promoting the right values and the need to invest a part of its profit into the community. } \\
\text { Reports on SD and CSR are available in GRI reports since } 2014 \text { to present. }\end{array}$ \\
\hline Adris Group & $\begin{array}{l}\text { At the level of the group, there is no special dedicated website in the field of SD and CSR, } \\
\text { but there are sites at the level of constitutive companies (both in English and Croatian). } \\
\text { Stakeholders: From general information of the Group, we can read that stakeholders of } \\
\text { SD are: customers, investors, local community. } \\
\text { Social mission: At the level of the group, there is no explicit information available. But, } \\
\text { at a part covering their Foundation, we can read the following: The mission of the Adris } \\
\text { Foundation is to promote Corporate Social Responsibility and to contribute to the ad- } \\
\text { vancement of the Croatian society. The vision of the Adris Foundation is to participate } \\
\text { in the establishment of social justice, equal opportunities, better conditions and quality } \\
\text { of life of Croatian citizens and to create a competitive and socially-responsible economy, } \\
\text { based on knowledge and innovation. } \\
\text { Reports on SD and CSR are a constitutive part of Annual Reports. }\end{array}$ \\
\hline
\end{tabular}

Source: Own elaboration based on (Polsat, 2020; LPP SA, 2020; Polpharma, 2020; Podravka, 2020; Atlantic, 2020a; 2020b; 2020c; Adris, 2020a; 2020b). 


\subsection{Global and local perspectives of sustainable development}

In the previous part, we pointed out that mission, vision and strategic objectives of a company should be formulated in accordance to UN SDGs that are expressed as global sustainability agenda over some period. However, if we dig a little bit deeper into those global goals, we will see that they are formulated in an idealistic way. There is an ongoing debate as to how a company or organisation can address all those goals and contribute to global sustainability. In addition, there are numerous definitions of sustainability, and in this book, in various chapters, we elaborate on them from various aspects. Definitions can be simple, given in the form of a short statement outlying just basic principles and not giving any clue as to which area of a company, organisation or local community should conduct its everyday activities. Or, on the other hand, definitions can be very complex, providing detailed insight into areas covered and/or practical instructions how to organise everyday life in the long-run, without diminishing natural resources.

According to Sandhu, Harris, \& McKenzie (2014, pp. 1-14), Brundtland's classical definition of sustainability is an example of a simple, ideal, global definition. While Sustainable Seattle's Indicators of a Sustainable Community, or Sustainability Reporting Guidelines from the Global Reporting Initiative are examples of a complex, ideal, local definition of sustainable development. Grey (2010) points out that assessment of an organisation's impact on planetary sustainability is almost impossible and that it is hard to conceptualise frameworks and measurement systems in that sense. Nonetheless, Sandhu et al. (2014, p. 3) argue that organisations can make a meaningful contribution to the global sustainability agenda, without trying to assess contribution to all aspects and overall planetary sustainability. Therefore, taking the need of balance between local and global sustainable actions into account, Sandhu et al. (2014, p. 3) propose the following definition of sustainability: "Sustainability is a collective, progressive and self-reflexive activity, undertaken within communities, designed to develop more sustainable relationships with the natural environment, including its own members and members of other communities".

At a local level, this definition allows to indicate that sustainability is a continuous, progressive action, which requires active engagement of different members of community (individuals, companies, NGOs, local government, national governments, etc.). Also, this definition includes an aspect of continuous self-reflection and improvement of one's own actions and policies in order to make a substantive and meaningful change in individual or organisational behavior, further contributing to the realisation of some part of SDGs on a global level.

For many years, there was a tendency to promote sustainable development in a top-bottom manner, starting from global sustainability impulses, which are spreading from the global level in form of policies, actions and principles, to local 
levels all the way to organisations and individuals (Cavallaro \& Dansero, 1998). Nowadays, we have a broader view and bottom-up social initiatives starting from a local level with an aim to influence global sustainability are growing rapidly because organisations and individuals are now, more than ever before, aware and informed of the problems related to poverty, ecology and health issues. Therefore, today, the integration of local and global approaches must be in focus if we want to ensure sustainability in the long-run. In this sense (when planning corporate sustainability strategy regarding the local or global level), apart from the UN SDGs, special attention should be paid to local factors influencing the operation of a company. Epstein and Rejc Buhovac (2014, p. 60) suggest companies take internal factors into account (such as: corporate culture, competitive position and sustainability performance of a company), and external factors (such as: regulations, market conditions and geographic factors).

\subsection{Conflict of Sustainable Development Goals in organisation}

When we analyse SDGs, we can conclude that sustainable development has 3 main pillars: (1) striving for increasing economic efficiency (economic development and economic growth), (2) fostering social responsibilities (social progress and social inclusion), and (3) improvement of environmental protection. At first glance, it may seem that all 3 pillars are in harmony and that sustainable development is an easy task for a company or organisation to realise. Nevertheless, in practice, that is not the case, and it is not true, neither on a global or local level, nor on the level of a particular organisation or company.

The pillars of sustainable development are in intertwined interaction and they cannot stand on their own without influencing one another. Therefore, sustainable development requires a holistic approach, and when a company or organisation or even local or national government develops a sustainable development strategy, it has to take all pillars for each strategic goal into account. Moreover, interrelationships between pillars should be analysed and balanced as well. For instance, continuous economic growth can be detrimental to social welfare and for ecology, if it is conducted in a manner that does not consider the role of a company in a local community and its social responsibility towards all stakeholders, including the environment aspect.

There are studies in which the existence of conflict is elaborated on, even within the UN's SDGs.

For instance, Spaiser, Ranganathan, Bali Swain, \& Sumpter (2017) tested the consistency of 17 UN SDGs by applying an extensive set of indicators in official statistics measuring global social and economic development. They came to several 
conclusions: (1) economic growth fulfills socio-economic, while hindering environmental goals, however, (2) factors can contribute to socio-economic development (such as health programmes and government spending on welfare programmes) without diminishing the ecological goal of renewable energy usage.

Mika and Farkas (2017) contribute to the debate providing insight into conflicts of the "renewable energy" goal with other SDGs. They claim and test the following conflicting goals and targets when discussing renewable energy usage: (1) "End hunger, achieve food security and improved nutrition, and promote sustainable agriculture", (2) "By 2030, double the agricultural productivity and the incomes of small-scale food producers, in particular women, indigenous people, family farmers, pastoralists and fishers, including through secure and equal access to land, other productive resources and inputs, knowledge, financial services, markets, and opportunities for value addition and non-farm employment", (3) "Protect, restore and promote sustainable use of terrestrial ecosystems, sustainably manage forests, combat desertification, and halt and reverse land degradation and halt biodiversity loss" and (4) "By 2020, promote the implementation of sustainable management of all types of forests, halt deforestation, restore degraded forests, and increase afforestation and reforestation globally".

In addition, Yamagata (2017) claims that poverty reduction and other sustainable issues are in conflict in their nature because poverty reduction goals address only a limited number of humans, while all other goals are oriented towards universal benefits of all humans. He claims that there can be only a part of sustainable development projects, which contribute to both to sustainability and poverty reduction. Some corporate donors even emphasize their orientation towards ecological and economic efficiency rather than emphasizing the poverty reduction goal. They will prefer to put efficiency in food production and distribution by avoiding the waste of food surpluses than to emphasize help provided to people experiencing material deprivation in their business strategies.

Trisos et al. (2019) elaborate on the necessity to map SDGs conflicts when developing sustainability strategy in order to: (1) identify regions with high potential SDG conflict, and (2) provide it as a boundary object that can be discussed from various viewpoints and that can facilitate open discussion. Also, they proclaim collaboration of different sectors involved in a sustainable project. In their study, the process of mitigating SDG conflicts is illustrated via the mosquito net fishing example in central Africa.

Brunet et al. (2020) describe how SDGs can be in conflict when a large-scale photovoltaic power plant is implemented and they suggest the methodology to be applied when planning such a strategic project. The proposed methodology can be used in the strategic planning of sustainable development for other entrepreneurial projects. They indicate that in strategic SD planning economic, social, environmental, energy, water and food, governance and land should be analysed 
by addressing the major positive impact, impact that can be improved at local, regional, national and international levels. In their paper, they give a vivid example of a plant in Madagaskar, but tables can be used as a tool for SD strategic planning in all industries (see Table 3). One table has to be produced for each level of impact, which means that each project or initiative will develop 4 different tables: one for local, one for regional, another for national and one for international impact. Such tables provide comprehensive insight on areas with high risks and high potentials of a certain SD project or initiative. Moreover, they could be a basis both for effective activity plan development and for communication with sustainability stakeholders on different levels.

Table 3. Tool for assessing SD impact

\begin{tabular}{|l|l|l|}
\hline \multicolumn{3}{|c|}{ Level: International / National / Regional / Local } \\
\hline Economic & $\begin{array}{c}\text { Major positive impact of the SD } \\
\text { project or SD initiative }\end{array}$ & $\begin{array}{c}\text { Major impact to be improved by the } \\
\text { SD project or SD initiative }\end{array}$ \\
\hline Social & & \\
\hline Environmental & & \\
\hline Energy & & \\
\hline Water and food & & \\
\hline Governance and land & & \\
\hline Women & & \\
\hline
\end{tabular}

Source: Adapted according to (Brunet et al., 2020).

\section{Questions / tasks}

1. Find the official UN webpage regarding SDGs. Choose one of the following topics (1) poverty and hunger, (2) clean energy, (3) improving health or (4) reducing inequalities. Investigate the topic and prepare a short report on areas included in the topic, policies implemented, measurable goals, etc.

2. Continue research on one of topics from task 1 , and give an example of a company or organisation dealing with the chosen topic in your local community. Describe the way it operates and its role in SDG achievement.

3. Name 2 companies from your country in the following industries: food manufacturing, tourism, retail and fashion production. For each company, provide some ideas as to how they could incorporate the UN SDGs into their mission or vision statement. Take their current operation and their market position into account.

4. Find 3 companies on the list of the most successful companies in your country. Go to their websites and analyse how they communicate sustainability. Prepare 
a short report on web structure, available information on addressed sustainability areas and aspects; cite some examples of the stated sustainability mission, vision or objectives for each company.

5. For the same companies given in task 3 , analyse and comment on the most recent GRI report (if available).

6. For the same companies as given in task 3, research newspaper articles and provide a critical opinion-is sustainability really included into their everyday business practice? Outline some real-life examples of activities performed by those companies in the local community to support your arguments.

7. Compare Brundtland's definition of sustainable development with the definition and set of measurements found in the GRI guidelines. Discuss which of those is easier to fulfill and follow up from a managerial perspective.

8. Discuss ways in which some local company can be proactive in sustainable development activities and how a business can promote its best sustainability practices to become standards of conduct on a local level.

9. Give at least 3 examples of how good SD goals can cause detrimental effects on other SDGs.

10. Choose $1 \mathrm{SD}$ initiative or objective from the following list and use the suggested table from chapter 2.1.3. to assess its impact. List of SD initiatives or objectives: (a) car manufacturer will switch $50 \%$ production capacities to electric cars by 2030, (b) fish farm will expand production by $30 \%$ and employ 150 new workers, (c) food factory will use $100 \%$ bio degradable packaging made from oak bark, plastic packaging will be fully removed by 2030 , (d) farm will reduce production of cow meat by $20 \%$ and increase production of chicken meat by $30 \%$ in the next 2 years.

\section{References}

Adris (2020a). Retrieved December 10, 2020 from https://www.adris.hr/odnosi-s-javnoscu/zaklada-adris/o-zakladi/tko-smo/

Adris (2020b). Retrieved December 10, 2020 from https://www.adris.hr/odnosi-s-javnoscu/odnosi-s-investitorima/financijska-izvjesca/2018/

Atlantic (2020a). Retrieved December 7, 2020 from https://www.atlanticgrupa.com/en/social-responsibility/

Atlantic (2020b). Retrieved December 7, 2020 from https://www.atlanticgrupa.com/hr/drustvena-odgovornost/

Atlantic (2020c). Retrieved December 7, 2020 from https://www.atlanticgrupa.com/en/media/publications/gri-report/

Brunet, C., Savadogo, O., Baptiste, P., Bouchard, M. A., Rakotoary, J. C., Ravoninjatovo, A., ... Merveille, N. (2020). Impacts generated by a large-scale solar photovoltaic power plant can lead to conflicts between Sustainable Development Goals: A review of key lessons learned in Madagascar. Sustainability, 12(7471), 1-33. 
Cavallaro, V., \& Dansero, E. (1998). Sustainable development: global or local?. GeoJournal, 45(1-2), 33-40.

Croatia.eu. land and people. (n.d.). The economy. Major companies. The largest private companies. Retrieved from https://croatia.eu/index.php?view=article\&id=33\&lang=2

Epstein M. J., \& Rejc Buhovac, A. (2014). Making sustainability work. Greenleaf Publishing Ltd. and Berret-Koehler Publishers, Inc.

Grey, R. (2010). Is accounting for sustainability actually accounting for sustainability and how would we know? An exploration of narratives of organisations and the planet. Accounting Organizations and Society, 35(1), 47-62.

Griggs, D. (Ed.). (2013). Sustainable Development Goals for people and planet. Nature, 495(March), 305-307.

Kuisma, J. (2017). Managing corporate responsibility in a real world. Palgrave Macmillan.

LPP SA (2020). Retrieved December 10, 2020 from https://www.lppsa.com/en/sustainable-development

Mika, J., \& Farkas, A. (2017). On synergies and conflicts between the Sustainable Development Goals (2016-2030) and renewable energy sources for education of and by sustainability. Problems of Education in the 21st Century, 75(2), 182-193.

Podravka (2020). Retrieved December 6, 2020 from https://www.podravka.com/responsibility/ and https://www.podravka.hr/kompanija/odgovornost/odrzivi-razvoj/

Polpharma (2020). Retrieved December 10, 2020 from https://polpharma.pl/en/responsibility/

Polsat (2020). Retrieved December 11, 2020 from https://grupapolsat.pl/en/sustainability

Sandhu, S., McKenzie, S., \& Harris, H. (2014). Linking local and global sustainability. Springer.

Spaiser, V., Ranganathan, S., Bali Swain, R., \& Sumpter, D. J. T. (2017). The sustainable development oxymoron: quantifying and modelling the incompatibility of Sustainable Development Goals. International Journal of Sustainable Development \& World Ecology, 24(6), 457-470.

Szeligowski, M. (2019, October 31). Ranking „Forbesa”. Top 10 największych polskich firm prywatnych. Retrieved from https://spidersweb.pl/bizblog/forbes-dziesiec-polskich-firm-2019/

Trisos, C. H., Alexander, S. M., Gephart, J. A., Gurung, R., McIntyre, P. B., \& Short, R. E. (2019). Mosquito net fishing exemplifies conflict among Sustainable Development Goals. Nature Sustainability, 2 (January), 5-7.

UN (2021a). Millennium Development Goals. Retrieved February 8, 2021 from https://www.un.org/ millenniumgoals/

UN (2021b). Sustainable Development Goals. Retrieved February 8, 2021 from https://www.un.org/ sustainabledevelopment/blog/2015/12/sustainable-development-goals-kick-off-with-start-of-new-year/

UNESCO. (n.d.). Natural sciences. Millennium Development Goals. Retrieved from http://www. unesco.org/new/en/natural-sciences/science-technology/engineering/sustainable-engineering/ millennium-development-goals/

UN SD Agenda 2030. (2021). Transforming our world: the 2030 Agenda for sustainable development. Retrieved February 10, 2021 from https://undocs.org/A/RES/70/1

Yamagata, T. (2017). Sustainable Development Goals and Japan: Sustainability, overshadows poverty reduction. Asia-Pacific Development Journal, 23(2), 1-17. 


\title{
2.
}

\section{SUSTAINABLE DEVELOPMENT IN MARKETING STRATEGY}

\author{
Atanaska Reshetkova \\ The D. A. Tsenov Academy of Economics
}

\begin{abstract}
Marketing strategy is an important part of every business strategy because it is crucial in attaining marketing goals and to grant the overall success of a company. Broadly speaking, marketing strategy allows to define the long-term marketing goals of a firm and what needs to be done in order to achieve these goals. This provides a set of planned steps to bring the marketing mix into the desired state to achieve the overall business goal. In this sense, the marketing strategy is never created independently based on the corporate level strategy.

Marketing management has evolved over the past decade to become customer-cantered, and it continues to change along with consumers. It is not surprising that the concept of sustainable development (SD) has left its footprints on marketing strategy, as today it has strong impact on the consumer's mind and behaviour. Managers face the challenge of incorporating the main dimensions of sustainability into the marketing strategy-environmental, social and economic aspects. The main goal of this chapter is to explain how SD is integrated with marketing.
\end{abstract}

Keywords: customer value, sustainable development, sustainability marketing. 


\subsection{Sustainability as a source of value for customers}

Sustainable development is a concept that recommends a set of ethical-oriented goals for nations aspiring to make economic growth widespread, to encourage social welfare, and to protect the environment from human-induced degradation (Sachs, 2015, p. 3). Globally, consumers are focusing their preferences towards products and brands implementing different innovations to promote sustainability. Environmental awareness increases, and this makes consumers look for and choose eco-friendly products, to avoid waste and reuse products and materials (Euromonitor International, 2020). Marketing managers have foreseen this shift and adapted their marketing strategies accordingly. Although this is indeed a challenge for some, shifting to a more sustainability-oriented approach in the market is an opportunity for growth as it is a source of value for customers. At the very heart of today's marketing is the creation of value for customers. Marketers are always looking for new ways to satisfy their targeted customers by adding value to their offers. However, before we comment on how different aspects of sustainability can be incorporated into a marketing strategy to create, communicate and distribute value to customers, let us consider this definition of customer value (Woodruff, 1997, p. 142):

Customer value is a customer's perceived preference for and evaluation of those product attribute performances, and consequences arising from use that facilitate (or block) achieving the customer's goals and purposes in use situations.

According to this definition, customer value is created when product attributes perform in a way that enables the customer to achieve his/her goals when/after product usage occurs. To create value, a marketer first has to know which product attributes are important for customers in various use situations. During the product development stage, those attributes must be considered at their sufficient levels so that the product performance will be evaluated favourably by the consumer. In other words, companies can create products that are valuable for consumers only after they have conducted market research to get insight into what is valuable for the targeted customers. Then, an appropriate way to communicate this value must be implied because sometimes, the value is not immediately recognised. This can be done by putting labels on the product itself (such as "eco-friendly", "organic", "bio", "made with natural ingredients", "recyclable", etc., depending on the type of product) and by advertising. Of course, the product must possess the qualities and attributes it claims to have, otherwise this type of communication is unethical and deceiving. The last step is to deliver value to customers, and it is very important to communicate only value-adding attributes that are real and can be provided by the product. 
There is evidence that sustainable corporate management and investment practice can actually improve the performance of a company (Clark, Feiner, \& Viehs, 2015):

- firms with sound sustainability standards enjoy a lower cost of capital;

- superior sustainability standards improve corporations' access to capital;

- environmental risk management practices and disclosure on environmental policies lower a firm's cost of equity;

- social factors, such as employee relationships and good workforce practices, have strong impact on operational performance;

- corporate eco-efficiency and environmentally responsible behaviours are viewed as the most important factors leading to superior stock market performance.

As a part of sustainable corporate management, marketing management also sets sustainability goals and creates specific marketing programmes. This type of marketing is known as sustainability marketing, and it can be defined as follows (Lunde, 2018):

Sustainable marketing is the strategic creation, communication, delivery and exchange of offerings that produce value through consumption behaviours, business practices and the marketplace, while lowering harm to the environment and ethically and equitably increasing the quality of life (QOL) and well-being of consumers and global stakeholders, presently and for future generations.

The theoretical background of sustainability marketing is vast and based on various socio-psychological, business and institutional, as well as behavioural theories. The value created by sustainability marketing is extended in a way that products deliver not only benefits to the consumer, but society at large. It should be noted, however, that companies operate on the market with an expectation for a certain level of profit. It is unlikely for a company to undertake changes in its marketing strategy towards more sustainable ways of conducting marketing if this change will only raise costs and not bring more value to the company. In Figure 1, the concept of extended customer value is shown, which includes 4 models of value creation:

1) Creating value for individual customers and the company.

2) Creating value for the public and the company.

3) Creating value for the public and individual customers.

4) Creating value for the public, individual customers and the company.

Although some consider 'profit' and 'value for society' as a major trade-off, this is not necessarily true. In order to compensate for the investment in shifting to more sustainable offers, marketing managers must change pricing strategy as well. This is possible if the targeted segment is less price sensitive. It is demonstrated in research that interest in sustainable products peaks after the age of 30, which 
is in line with increased disposable income and earning potential, although not all consumers are willing to pay more for sustainable products-they still look for affordable and convenient products (Euromonitor International, 2020).

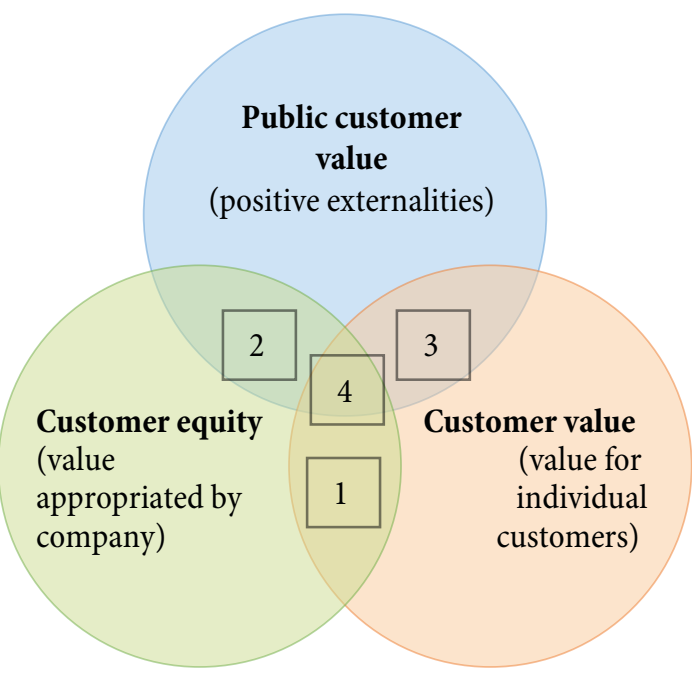

Figure 1. Concept of extended customer value

Source: (Lüdeke-Freund, 2010).

Within Europe, there are still different perceptions regarding the importance of social welfare as a source of personal well-being and life satisfaction. People in more developed countries, with more efficient economies, have recognised how prominent the prosperity of the society generally is for individuals. Public policies, concerning sustainability, are now the main focus of interest and people are getting more and more concerned with the welfare of future generations. This has strong impact on consumers and the way they evaluate, chose, buy, consume and dispose products. Anyway, there are cross-cultural differences in the extent to which consumers value the sustainability concept, and thus, "sustainable-oriented" consumer segments vary in size and demographics across countries.

\subsection{Social and environmental aspects of sustainable development in marketing strategy}

In this part, we focus on the 2 most important dimensions of sustainable development within the context of consumer behaviour and marketing-social and environmental aspects. The economic aspect of SD is related to the long-term economic 
growth that is preserving the natural resources and quality of the environment for future generations. In other words, the economic aspect of SD is not associated with marketing strategies and actives as much as the other 2 aspects of SD, and this is why we will not discuss this aspect here. However, by changing consumption patterns and attitudes towards sustainable products, sustainability marketing can also foster sustainable economic growth.

There are a couple of marketing concepts/strategies that have, to some extent, incorporated the idea of sustainability in marketing. These concepts have changed and blended in recent years, but yet, they can be described as fundamental for today's understanding of the role of social and environmental sustainability in marketing strategy.

\section{Social marketing}

The ability of marketing to solve not only the individual consumers' problems but also to contribute to solving societal issues is an idea that has existed in the world of marketing practitioners for a very long time. For example, Kotler and Zaltman view social marketing as "a promising framework for planning and implementing social change" (Kotler \& Zaltman, 1971, p. 3). However, the early understanding of social marketing is quite different from the meaning regarding the social aspect of sustainable development. Social marketing connects the target audience with some socially significant cause or idea using traditional marketing tools. In practice, social marketing differs from the traditional one but only in the field of its application, but it uses the same techniques. Most often, it is about promoting non-profit organisations and their campaigns.

\section{Cause marketing}

The focus of this form of marketing is the creation of marketing programmes that are aimed at supporting all kinds of charitable causes. Companies selling conventional products are constituting partnerships with non-profit organisations, helping them raise funds or buy equipment, materials, etc. for their activities. This partnership is mutually beneficial because the non-profit organisation receives support, and the for-profit companies, their image is improved and achieves higher sales rates because people feel good when they support causes. This approach is widely used in promotional campaigns but it can also be a core part of a firm's business model.

\section{Ecological marketing}

This type of marketing orientation is the earliest form of recognition concerning the role that marketing can play when trying to solve issues such as water and air pollution, the use of pesticides, and other major ecological problems. Ecological marketing is used to overcome already existing issues regarding the harm that 
humans (and more specifically-businesses) cause to the environment. It deals with factors affecting these ecological problems and companies that are considered the most serious threats in preserving nature. We must note that all the efforts here are directed towards the companies and their compliance with new legislation that obliges companies to take specific measures to protect the environment (Katrandjiev, 2016).

\section{Green marketing}

This concept has existed for more than 2 decades, and its basic idea is to identify and target those consumers who are concerned about the environment and want to minimise their negative impact on it through a change in their consumption patterns. A company that implements a green marketing strategy would demonstrate its willingness to preserve nature while offering environmentally-friendly products and adjust its marketing mix to the specific needs and wants of the 'green consumer'. Green marketing features different activities, such as:

- changes to the production process;

- product and packaging modifications;

- product innovations/creation of entirely new products;

- sustainable ways to dispose of a product;

- new product positioning strategy;

- changes in communication messages;

- promotion of 'green' improvements in a company;

- changes in prices and pricing policies;

- optimisation of distribution channels;

- introduction of short supply chains;

- the CO2-neutral footprint of transportation.

\subsection{Sustainability marketing: changes in the marketing mix}

The concept of marketing mix is greatly essential for contemporary marketing, that it is impossible to talk about a shift towards sustainability marketing without commenting on the necessary changes in the $4 \mathrm{Ps}$ - product, price, place, and promotion, as a part of any marketing strategy. All changes in the marketing mix should be coherent, of course, and they are indeed a result of changing consumer perceptions and preferences. In the following Figure 2, it can be seen how the traditional marketing mix can evolve in terms of changing the focus of its elements so that the result is a more consumer-oriented sustainability marketing mix.

- Sustainable products provide customers with a solution to both consumer and socio-ecological problems of a larger scale. 
- The price of a product from a consumer point of view consists of all costs for acquiring, using and disposing the product.

- Marketing needs to create convenience for customers in a sustainable way.

- Promoting the product means to initiate two-way communication with the audience.

Traditional marketing mix
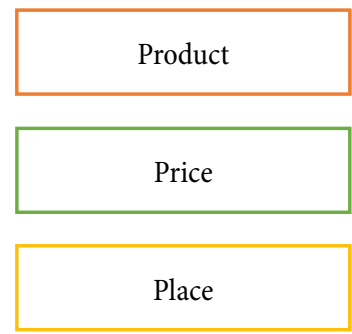

Promotion

\section{Sustainability marketing mix}

Customer solution

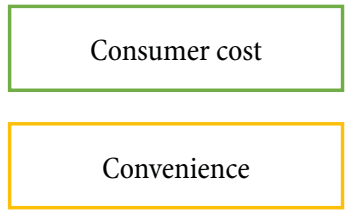

Communication

Figure 2. Traditional marketing mix (McCarthy's 4Ps) vs. sustainability marketing mix (Peattie \& Belz 4Cs)

Source: (Kumar, Rahman, Kazmi, \& Goyal, 2012).

While we bear this novel conceptualisation of the marketing mix in mind, we use the original elements in the following discussion.

\section{Product}

When a company wants to make a business sustainable, it usually starts with changes in the product. The reason is that it is the product and its attributes that are most important for customers who are concerned with sustainability. Customers are satisfied with a product when it performs at least as well as it was expected by the customer. In other words, customers have expectations about the product, and only when these expectations are met or even exceeded, customers are satisfied with their choice. This is essential for the long-term market success of a product. Within the context of sustainability marketing, customers may have expectations about the typical product attributes and the product's impact, for example, on the environment. This must be well-understood when developing new product offerings. The extraction of raw materials, their transportation, and the manufacturing process itself, are not explicitly a decision of marketing managers, but sustainability must be considered at each of these steps in order to define a company as sustainable. There are certain product attributes that are achievable only if the manufacturing process is adapted to the sustainability strategy. In Table 1, the main categories 
of product attributes related to social and environmental sustainability aspects are expected. The social sustainability product attributes are ensured by adopting labour-related practices that rule out any possibility of unfairly treating workers, and by selecting suppliers that comply with the company's sustainability policy. It is also important to guarantee products and/or manufacturing processes are not harmful to the health of both workers and customers. These Corporate Social Responsibility practices should be communicated to customers and information should be easily accessible and transparent.

The environmental sustainability product attributes may include, for example, the use of renewable energy sources during the production stage; use of recycled materials; product origin; extended durability; low ecological impact of suppliers and partners; low environmental impact during usage; recycling the product (or its parts) at the disposal stage.

If we consider the consumer decision-making process, at the product evaluation stage, the environmentally-conscious consumer would consider only products that possess a given set of sustainability attributes she/he finds important. Any product that does not have these attributes will not be included in the initially considered set. Nonetheless, being in this set does not guarantee that the consumer will buy this particular product. Even if sustainability attributes are significant for consumers, there are still other product attributes that may have stronger influence on consumer buying behaviour.

\section{Table 1. Product attributes linked to social and environmental aspects of SD}

\begin{tabular}{|c|c|}
\hline Social sustainability attributes & Environmental sustainability attributes \\
\hline - health, welfare, and social justice & $\begin{array}{c}\text { preserving natural resources and the environment } \\
\text { - involving issues concerning workers and suppli- } \\
\text { ers (e.g. fair wages and treatment of those provid- }\end{array}$ \\
$\begin{array}{c}\text { ing raw materials and products), consumers (e.g. } \\
\text { guaranteeing products offer real value and are not } \\
\text { harmful), and communities (e.g. guaranteeing the } \\
\text { and ecosystems }\end{array}$ \\
$\begin{array}{l}\text { development of productive, healthy and rewarding } \\
\text { communities) }\end{array}$
\end{tabular}

Source: (Bangsa \& Schlegelmilch, 2020, p. 5).

Positive customer attitudes towards sustainable products do not always lead to a purchase, and the nuances of consumer behaviour in this regard are still not fully understood (Wiederhold \& Martinez, 2018). Most of the research focused on the way sustainability attributes influence consumer choice and decision-making allow to examine the following variables as a measure of behaviour: consumer choices or preferences, willingness to buy or pay, intention to adopt or purchase, and consumer evaluation and perceptions (Bangsa \& Schlegelmilch, 2020). In Table 2, the key factors linked to sustainability product attributes that affect consumer choice 
are presented. The variety of possible levels regarding these factors indicate that many variables may influence the actual behaviour of sustainability-conscious consumer segments. Only part of them are under the control of marketing managers, and their planning should be undertaken while considering the other drivers of consumer choice.

Table 2. Key drivers of consumer choice regarding sustainable products

\begin{tabular}{|l|l|}
\hline \multicolumn{2}{|c|}{ Consumer factors } \\
\hline Socio-demographic & Age, gender, education, income, etc. \\
\hline $\begin{array}{l}\text { Beliefs, values, attitudes, knowledge, } \\
\text { perceptions }\end{array}$ & $\begin{array}{l}\text { Personal values, environmental concern, environmental and social } \\
\text { consciousness, environmental literacy, perceived consumer effec- } \\
\text { tiveness, self-efficacy, self-construal, equity sensitivity, consump- } \\
\text { tion value perceptions, consideration of future consequences, value } \\
\text { orientation }\end{array}$ \\
\hline Intentions & Propensity towards pro-social behaviour \\
\hline Habits and lifestyle & $\begin{array}{l}\text { Consumption pattern and habits (type of product, frequency), health- } \\
\text { conscious lifestyle }\end{array}$ \\
\hline \multicolumn{2}{|c|}{ Marketing and purchase factors } \\
\hline Sustainable labels & $\begin{array}{l}\text { Organic, fair-trade, Rainforest Alliance, } \\
\text { GMO-Free, locally produced, animal welfare, CO2-reduced, energy } \\
\text { labels, SA 8000, recyclable, biodegradable, etc. }\end{array}$ \\
\hline Product type & Different product types (e.g. hedonic vs. utilitarian product) \\
\hline Sustainable attributes & Sustainable packaging, production, transport, materials, etc. \\
\hline Product attributes & $\begin{array}{l}\text { Brand name, price, product quality, product performance, taste, } \\
\text { shape, visual appeal, etc. }\end{array}$ \\
\hline Product benefits & Gentleness, strength, healthiness, hedonic, utilitarian, etc. \\
\hline Product origin & Local/regional/international, country of origin \\
\hline Message and communication & $\begin{array}{l}\text { Consumer education and } \\
\text { message-framing, message condition and prediction request }\end{array}$ \\
\hline Situational context & Response mode compatibility \\
\hline & Social and structural context \\
\hline Social pressure & Social pressure \\
\hline Social influence & Social influence, herd behaviour, social learning \\
\hline Extrinsic motivational factors & Government role, media exposure \\
\hline
\end{tabular}

Source: (Bangsa \& Schlegelmilch, 2020, p. 9).

\section{Price}

Determining a sustainable product's price should be done after a considerable amount of data analysis, as this element of the marketing mix generates revenues and is directly related to profitability. At the same time, it is a tool for direct influence of demand and a dimension in product positioning strategy.

From a customer point of view, price represents the monetary sacrifice that is needed to obtain a product. To decide whether to buy a product or not, the customer would compare the perceived value of the product with the price that he or she 
has to pay for it. If the perceived value that comes from using or simply possessing the product is evaluated as greater than its price, then the customer will buy the product. In other words, if the customer thinks and/or feels that the given product would solve his/her problem, then the purchase will occur. Remember that most product choices are made within the context of budget constraints, thus, this also plays a major role in buying behaviour.

It is considered that most sustainable products have higher prices because:

1) Using renewable sources of energy, clean or bio ingredients, and eco-friendly manufacturing process, etc., is generally more expensive.

2) Creating proper working conditions, giving fair wages, and having a good social policy for workers increases the costs of a company and thus-contributes to the higher prices of production.

If the benefits for society and the environment are important to customers, higher prices will be considered appropriate for the additional value that comes with sustainable product choices. That is why it is very important to communicate this added value and to educate customers on sustainability issues and their possible solutions.

The price is not equal to the overall cost that any customer needs to pay in order to have, use and dispose of a product. The overall cost typically consists of the following elements:

1) product price - this is the initial cost to acquire a product; prices of sustainable products may be higher than those of conventional ones, but this may be compensated by, for example, longer durability;

2) costs related to the purchase-these costs are associated with the purchase but are not included in the product price, such as transportation costs to the store and then-back to the home of the consumer; sustainable products may be harder to find in many stores, thus, they might be associated with higher additional costs related to the purchase;

3) maintenance costs - any routine costs that arise from product usage that are not covered by the warranty or customer service; for example, an air conditioner should be serviced once a year;

4) costs of use-in order to use some products, the consumer needs to buy additional resources or pay fees; for example, owning and using a vehicle means the customer has to pay taxes and buy gasoline.

When setting the price of a sustainable product, marketing managers should think of all additional costs that may arise for the customer. Owning and using a sustainable product can involve a higher initial investment, but it may lead to lower overall costs in the long-term. Marketers should communicate this to potential buyers. Sometimes, people would not consider the overall cost, or they just lack the experience needed to make such an estimation. 


\section{Promotion}

Promoting sustainable products means to use all relevant communication channels in an effort to popularise the sustainability solutions that a particular product provides. Promotion activities have various objectives, some of which are (Belz \& Peattie, 2012):

- generating awareness about the product, brand or technology;

- informing consumers about the company and its sustainability activities, sustainable product attributes, or sustainable product attributes;

- reminding consumers about the product and its availability;

- persuading consumers to try a new product or an innovation;

- reassuring consumers of the product attributes and that past purchases of the product were sensible choices;

- motivating consumers to respond to the communicated message;

- rewarding consumers through the provision of direct benefits for loyalty or other behaviours;

- connecting with consumers through relationship-building activities and interactive communication.

One of the most considerable ways to communicate sustainability attributes is to use labelling. It is also vital to use various communicative activities to make sustainability practices as transparent for consumers as possible. For example, if a company uses recycled materials, a list of its suppliers will build trust. Very often, consumers are not well-informed of sustainability benefits and get confused while trying to find out whether the product is environmentally-friendly. If the company has any certification that proves that the product is indeed sustainable, it has to be mentioned. This could help consumers build trust in the brand and its communication.

Typically, communication has a different focus at each stage of the consumption process (see Table 3). A prominent part of marketing communication is expressing corporate sustainability efforts and social responsibility. These efforts are most likely a part of a company's public relations initiatives. However, they are also expressed implicitly by the product and its positioning.

Table 3. Sustainability communication throughout the consumption process

\begin{tabular}{|l|l|}
\hline $\begin{array}{c}\text { Stage of consumption } \\
\text { process }\end{array}$ & \multicolumn{1}{c|}{ Emphasis of communication } \\
\hline Pre-purchase & $\begin{array}{l}\text { generating awareness; influencing brand perceptions; increasing brand's sus- } \\
\text { tainability credentials }\end{array}$ \\
\hline Purchase & motivating consumers to purchase sustainable products \\
\hline Use & $\begin{array}{l}\text { encouraging changes in product usage as well as service, and thus - saving } \\
\text { resources and extending product durability }\end{array}$ \\
\hline Post-use & responsible disposal; encouraging recycling \\
\hline
\end{tabular}

Source: (Belz \& Peattie, 2012). 
Marketing communication can have a beneficial effect on consumer behaviour because it can influence consumption patterns and people's lifestyle in a way that makes them aware of the consequences of their actions as customers. Today, many companies promote sustainable consumption in one way or another, and even if this does not lead to an immediate purchase, it slowly changes the way customers perceive companies, products and technologies. Implementing production innovations that reduce environmental impact is expected from every company that wishes to be perceived as socially responsible. Customers gain knowledge on recycling and reuse options, they are interested in more durable products, and demand more detailed information about the production process and used materials.

\section{Place}

Transforming distribution to a more sustainable system means minimising the product's ecological footprint. This includes not only efforts to optimise the means of transport, but also to think about transportation packaging, re-use of materials, etc. The main points in this process are:

- local manufacturing - as the trend for shopping in local stores and preference for locally produced brands strengthens, some international companies are looking to acquire local business to capture new markets. Local manufacturing will reduce the distance between the producer and customer;

- eco-friendly means of transport-some vehicles have less ecological impact, such as railway or sea transport, or electronic cars. Technologically advanced companies also use drones to deliver goods to customers' homes;

- optimisation of vehicle load-using advanced optimisation approaches can help shorten the length of travelling routes and overall travel distance, which, in turn, reduces harmful emissions;

- recycled packaging materials - using recycled materials to protect the product from damage during transportation is one step, and it is also possible to start a programme to reclaim and re-use packaging materials already sent to the client;

- shorter supply chains - working with a minimal number of intermediaries means better control and support for partners who wish to improve their sustainability performance. Fewer intermediaries also mean less consumption of energy and other resources for keeping the goods in warehouses and repackaging, which also decrease the product's ecological footprint. 


\section{Questions / tasks}

1. What are the main barriers that deter consumers from re-evaluating their consumption patterns and adopting more socially and environmentally responsible behaviours?

2. Use the concept of 5 product levels introduced by Philip Kotler in the 1960 s to analyse the following sustainable products: compostable cutlery, solar-powered lawnmower, jewellery made from recycled, precious metals.

3. What are the most common sustainability advertising appeals that you have seen in different media? Give an example.

4. What are the limitations of classic advertising as a communication tool for sustainability marketing?

5. Point out several examples of how overall consumer costs for sustainable products can be reduced.

\section{References}

Bangsa, A. B., \& Schlegelmilch, B. B. (2020). Linking sustainable product attributes and consumer decision-making: Insights from a systematic review. Journal of Cleaner Production, 245. https:// doi.org/10.1016/j.jclepro.2019.118902

Belz, F.-M., \& Peattie, K. (2012). Sustainability marketing: A global perspective. Chichester: John Wiley \& Sons, Ltd.

Clark, G. L., Feiner, A., \& Viehs, M. (2015). From the stockholder to the stakeholder: How sustainability can drive financial outperformance. Retrieved from https://papers.ssrn.com/abstract=2508281

Euromonitor International. (2020). Top 10 global consumer trends 2020.

Katrandjiev, H. (2016). Ecological marketing, green marketing. Economic Alternatives (1), 71-82.

Kotler, P., \& Zaltman, G. (1971). Social marketing: An approach to planned social change. Journal of Marketing, 35(3), 3-12.

Kumar, V., Rahman, Z., Kazmi, A. A., \& Goyal, P. (2012). Evolution of sustainability as marketing strategy: Beginning of new era. Procedia-Social and Behavioral Sciences (37), 482-489.

Lüdeke-Freund, F. (2010). Towards a conceptual framework of 'business models for sustainability'. Knowledge collaboration \& learning for sustainable innovation. The Neitherlands: Centre for Sustainability Management (CSM).

Lunde, M. B. (2018). Sustainability in marketing: a systematic review unifying 20 years of theoretical and substantive contributions (1997-2016). AMS Review (8), 85-110.

Peattie, K., \& Belz, F.-M. (2010). Sustainability marketing-An innovative conception of marketing. Marketing Review St. Gallen, 27(5), 8-15.

Sachs, J. D. (2015). The age of sustainable development. New York: Columbia University Press.

Wiederhold, M., \& Martinez, L. F. (2018). Ethical consumer behaviour in Germany. Int J Consum Stud, 42(4), 419-429.

Woodruff, R. B. (1997). Customer value: The next source for competitive advantage. Journal of the Academy of Marketing Science, 25(2), 139-153. 



\title{
3.
}

\section{SUSTAINABLE DEVELOPMENT AND MARKET RESEARCH}

\author{
Iwona Olejnik \\ Poznań University of Economics and Business \\ Magdalena Stefańska \\ Poznań University of Economics and Business
}

\begin{abstract}
The issue of sustainable development is the subject of market research conducted by many institutions. Companies manufacturing products and providing services, institutions dealing with environmental or consumer protection, scientists and students, carry out many research projects related, for example, to sustainable, responsible consumption and production patterns, ensuring healthy lives and promoting well-being of all age groups, and much, much more.

The main goal of the chapter is to present how to use secondary data for analysis and how to prepare, conduct, analyse and interpret the results of primary research in the area of sustainable development (SD). There are many challenges facing researches. For that reason, it is necessary to discuss some of its ethical issues.

The structure of the chapter covers 3 topics:

1) research in SD based on secondary resources;

2) research in SD based on primary resources;

3) SD in market research-ethical aspects.
\end{abstract}

Keywords: ethics in market research, primary research in sustainable development, secondary research in sustainable development. 


\subsection{Sustainable development research based on secondary resources}

Sustainable development (SD) is a popular and important concept, but also one of the most complex ideas difficult to precisely define, and therefore, difficult to measure. However, methods and tools are continuously being developed to measure SD goals, predict future and create improved and innovative solutions to protect the environment and better human well-being.

The United Nations Commission on Sustainable Development (CSD) created in 1992, focused on the development and testing a suite of 58 indicators, condensed from an initial list of 134 indicators, which cover social and environmental issues. The Consultative Group on Sustainable Development Indicators (CGSDI), established in 1996, and consisting of experts, focused its work on creating a single sustainability index" (unctad.org). This work produced a "Dashboard of Sustainability", a set of 46 indicators organised into 4 clusters (environment, economy, society and institutions) for over 100 countries.

The 2030 Agenda for Sustainable Development defines 17 SDGs and 169 related targets that are to be achieved in the world by 2030. They concern achievements in 5 areas-the so-called 5xP: people, planet, prosperity, peace, partnership. They replaced the Millennium Development Goals, which were to be achieved by 2015 (United Nations, 2020).

The SD indicators are increasingly being used by national governments and international agencies for monitoring progress towards sustainability goals, as well as comparing performance among countries. However, as far as the organisation perspective is concerned, indicator estimation is important for planning one's own strategy and to secure the well-being of stakeholders. As a result, countries may increase the number of such indicators to better recognise the implementation of the SDG. The same can be done by organisations.

The full, current list of SDGs includes 17 goals, which are further elaborated in more detailed indicators (UNSTAT, 2020).

The main, secondary resources of $\mathrm{SD}$ are:

- international reports, which include comparative analysis (for example, that published by the UN: (The Sustainable Development Report, 2019; Sustainable Development Goals, 2019), Figure 1;

- government reports and statistics;

- institutional reports (prepared by NGO, research agencies, institutions organising rankings), for example, The Global 100 List $^{1}$;

${ }^{1}$ The Global 100 list includes only one percent of the world's leading corporations that stand out by conducting their business according to the principles of sustainable development. The lists are prepared by Corporate Knights, a company specialising in investment research, environmental protection, social responsibility and corporate governance (ESG), creating a ranking of global listed 
- reports prepared by organisations, i.e. by Prologis, one of the leading companies in SD (Prologis ESG Impact Report, 2019);

- articles in scientific journals, for example: Sustainability, International Journal of Sustainability In Higher Education, Journal of Sustainable Tourism, Transportation Research Part D: Transport And Environment, Journal of Industrial Ecology, Business Ethics, Journal of Cleaner Production, Business Ethics-A European Review, Business Ethics Quarterly;

- articles in newspapers and magazines.

\section{$\nabla$ OVERALL PERFORMANCE}

Index score

Regional average score
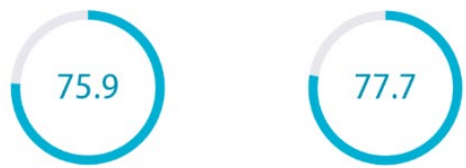

SDG Global rank 29 (OF 162)

\section{SPILLOVER INDEX}

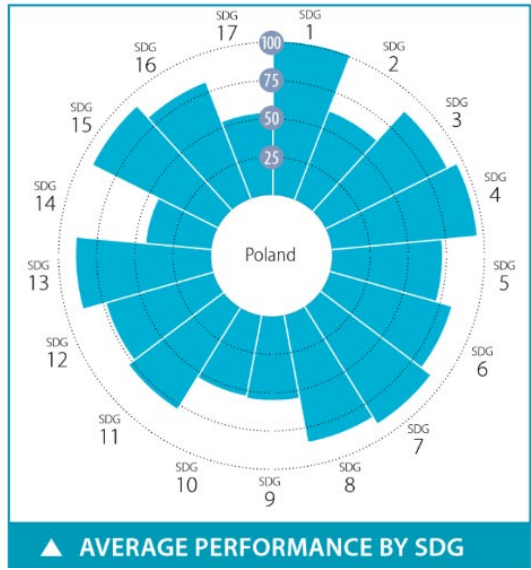

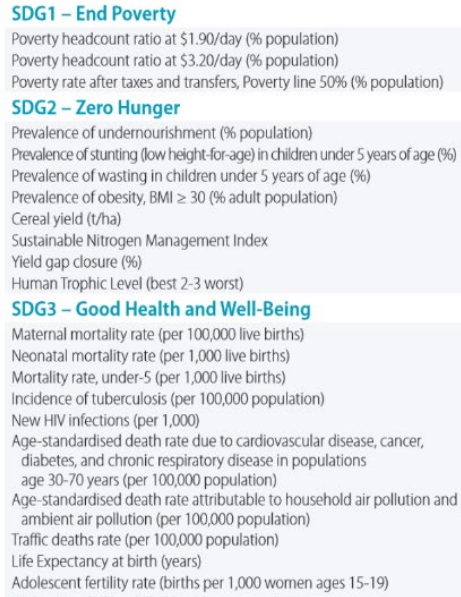

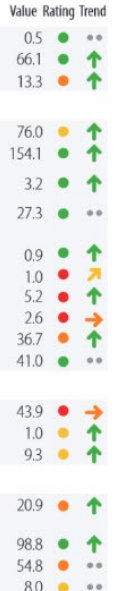

$80-\cdots$

\section{Figure 1. Level of achievements in SDG-Poland-2019}

Source: (Poland OECD countries, 2019).

companies. In 2020, the top of the ranking is opened by: The Danish holding company Chr. Hansen (1), the French Kering (2), the Finnish Neste, the Danish Orsted (4) and the British GlaxoSmithKline (5) (Prologis liderem..., 2019). 
Secondary resources for market research in SD are useful for:

- recognising state of knowledge and identifying gaps in knowledge;

- comparing countries, industries-for example, in rankings;

- analysing changes in time and space;

- identification the best practices;

- benchmark purposes;

- forecasting.

\subsection{Sustainable development research based on primary resources}

Among the issues undertaken as part of quantitative or qualitative research in SD, 3 key areas can be indicated: the state of knowledge regarding groups of respondents/awareness of the respondents concerning selected issues, the attitude towards a given problem and the respondents' behaviour when they need to make a decision (Churchill \& Iacobucci, 2018) (Table 1).

Table 1. Cognitive, affective and conative goals within the SD context-examples

\begin{tabular}{|c|c|c|}
\hline Cognitive goals & Affective goals & Conative goals \\
\hline $\begin{array}{l}\text { What do people know and un- } \\
\text { derstand? The state of knowledge } \\
\text { regarding selected groups of stake- } \\
\text { holders, e.g.: } \\
\text { - human rights; } \\
\text { - employee rights; } \\
\text { - representatives of selected social } \\
\text { groups; } \\
\text { - environment; } \\
\text { - sustainable consumption; } \\
\text { - sustainable production. }\end{array}$ & $\begin{array}{l}\text { What do people feel towards so- } \\
\text { cial, economic and environmental } \\
\text { issues (attitude, emotions) } \\
\text { e.g. attitude of employees towards: } \\
\text { - diversity; } \\
\text { - whistle-blowing; } \\
\text { - inclusion. }\end{array}$ & $\begin{array}{l}\text { What do people do, how do people } \\
\text { behave, e.g.:. } \\
\text { - participation in climate protests; } \\
\text { - defence of human rights; } \\
\text { - activity in social media; } \\
\text { - conducting research and pub- } \\
\text { lishing results. }\end{array}$ \\
\hline
\end{tabular}

Source: Own elaboration.

Primary market research in SD requires going through the following stages presented in Table 2 to create reliable and useful research (Bougie \& Sekaran, 2020; McDaniel \& Gates, 2018). 
Table 2. Project of research in SD theme-theoretical stages

\begin{tabular}{|c|c|}
\hline $\begin{array}{c}\text { Stages of } \\
\text { marketing } \\
\text { research }\end{array}$ & Stage description \\
\hline $\begin{array}{l}\text { Analysis of } \\
\text { situation }\end{array}$ & $\begin{array}{l}\text { Conducting desk research (secondary resources) - determining the reasons for } \\
\text { the need to conduct research, including: } \\
\text { - review of secondary data and current research on the analysed topic; } \\
\text { - diagnosing market conditions of the necessity to conduct research; } \\
\text { - presenting the situation of the organisation that conducts the research. }\end{array}$ \\
\hline $\begin{array}{l}\text { Defining } \\
\text { research } \\
\text { problem }\end{array}$ & $\begin{array}{l}\text { The problem is expressed by determining what is needed to be known to achieve } \\
\text { a given goal and how to obtain this knowledge. It is worth referring the problem } \\
\text { to the existing state of knowledge. Is it worth conducting primary research at all? }\end{array}$ \\
\hline $\begin{array}{l}\text { Defining } \\
\text { goal(s) }\end{array}$ & $\begin{array}{l}\text { Research objectives are derived from the types of decisions that are to be made } \\
\text { as a result of the research. }\end{array}$ \\
\hline $\begin{array}{l}\text { Scope of } \\
\text { research }\end{array}$ & $\begin{array}{l}\text { Subjective-who will we research? Households, enterprises, organisations? Who } \\
\text { is the target respondent for this company/firm? } \\
\text { Subject-what will we study? } \\
\text { Time-what time range will the questions refer to: retrospection, present or } \\
\text { future? } \\
\text { Spatial-where will the research be carried out? }\end{array}$ \\
\hline $\begin{array}{l}\text { Required } \\
\text { information }\end{array}$ & Defining what information is needed to solve the research problem. \\
\hline Hypothesis & $\begin{array}{l}\text { These are test statements/assumptions that will be verified during research (true/ } \\
\text { false). They express the research problem in the form of a series of statements } \\
\text { that constitute a tentative explanation of the relationships between the variables. }\end{array}$ \\
\hline $\begin{array}{l}\text { Research } \\
\text { methods }\end{array}$ & $\begin{array}{l}\text { Determining which research methods are optimal for solving a defined research } \\
\text { problem }^{2} \text {. }\end{array}$ \\
\hline Sample & $\begin{array}{l}\text { Determining whether the study will be conducted on the whole population or on } \\
\text { a sample? If on the sample, its size and method of selecting respondents should } \\
\text { be determined. }\end{array}$ \\
\hline $\begin{array}{l}\text { Methods of } \\
\text { analysis of } \\
\text { collected data }\end{array}$ & $\begin{array}{l}\text { Determining what methods will be used in analysis of the collected data (de- } \\
\text { scriptive statistics, advanced econometric methods, grounded theory, others). }\end{array}$ \\
\hline
\end{tabular}

Source: Own work based on (Neuman 2014; Creswell \& Creswell, 2018).

Synthetically described exemplary stages of the research process for qualitative and quantitative research are presented in Table 3. These examples relate to one of the SD objectives-"Ensure inclusive and equitable quality education and promote lifelong learning opportunities for all”.

${ }^{2}$ The choice of method depends on a number of factors, among which, the following are worth mentioning: the number of research questions and the level of their complexity, the degree of availability and the anticipated level of respondents' knowledge, the degree of control regarding the structure of the research sample, the possibility of using advanced measurement techniques and multimedia materials, the degree of respondent anonymity, duration of the research project, cost of the research. 


\section{Table 3. "Lifelong learning opportunities for all"-project examples of research within SD theme-basic assumptions ${ }^{3}$}

\begin{tabular}{|c|c|c|}
\hline \multicolumn{3}{|c|}{$\begin{array}{l}\text { Main assumption: Imagine that you intend to set up a company in the near future that will deal with training } \\
\text { and courses for adults. Before deciding to start a business, you intend to conduct primary research (both } \\
\text { quantitative and qualitative) }\end{array}$} \\
\hline $\begin{array}{c}\text { Stages of } \\
\text { marketing } \\
\text { research }\end{array}$ & Quantitative research & Qualitative research \\
\hline $\begin{array}{l}\text { Analysis of } \\
\text { situation }\end{array}$ & \multicolumn{2}{|c|}{$\begin{array}{l}\text { Before planning the primary studies, the first step is to analyse the secondary data. In this } \\
\text { regard, we need information on, among others: } \\
\text { - what is the structure of a given society according to education? } \\
\text { - how many entities with training courses and training operate, offering them to people } \\
\text { who have already completed their education? What are the features of their offer? } \\
\text { - how many people study at such courses? How many people do it on their own? How } \\
\text { do they do it? } \\
\text { - what are the characteristics of the offers of training companies? } \\
\text { - what studies have been carried out in this area so far and what are the most important } \\
\text { conclusions? } \\
\text { - other questions. }\end{array}$} \\
\hline $\begin{array}{l}\text { Defining } \\
\text { research } \\
\text { problem }\end{array}$ & $\begin{array}{l}\text { Defining consumer attitudes and opinions } \\
\text { about life-long learning, as well as the cur- } \\
\text { rent preferences and future intentions in } \\
\text { this regard. }\end{array}$ & Perception of life-long learning. \\
\hline $\begin{array}{l}\text { Defining } \\
\text { goal(s) }\end{array}$ & $\begin{array}{l}\text { Specifying how to encourage respondents } \\
\text { to undertake life-long learning. }\end{array}$ & $\begin{array}{l}\text { Preparation of a strategy to promote life-long } \\
\text { learning. }\end{array}$ \\
\hline $\begin{array}{l}\text { Scope of } \\
\text { research }\end{array}$ & $\begin{array}{l}\text { Subject: adults who have already completed } \\
\text { regular education. } \\
\text { Subject: see research questions. } \\
\text { Time range: experience with training in the } \\
\text { last } 2 \text { years, current status and plans for the } \\
\text { next } 6 \text { months. } \\
\text { Spatial scope: nationwide survey. }\end{array}$ & $\begin{array}{l}\text { Subject: adults who participated in at least } 1 \\
\text { course in the last } 12 \text { months and who have } \\
\text { no professional relationship with the en- } \\
\text { tity organising the training courses, are not } \\
\text { a teacher/trainer, etc. } \\
\text { Subject: see research questions. } \\
\text { Time range: as in quantitative research. } \\
\text { Spatial scope: } 3 \text { types of localities: large city } \\
\text { with over } 300,000 \text { inhabitants ( } 2 \text { groups), } \\
\text { small town-up to } 20,000 \text { inhabitants } \\
\text { ( } 2 \text { groups) and village ( } 2 \text { groups). } \\
\end{array}$ \\
\hline $\begin{array}{l}\text { Required } \\
\text { information - } \\
\text { research } \\
\text { questions }\end{array}$ & $\begin{array}{l}\text { How many people take part in life-long } \\
\text { learning coursers? } \\
\text { How often people... } \\
\text { How many times people... } \\
\text { What courses do they choose most often? } \\
\text { What are the reasons for choosing courses? } \\
\text { How do they rate the available offer? } \\
\text { What is the preferred form of classes? } \\
\text { How big should the training group be? }\end{array}$ & $\begin{array}{l}\text { Why the people... } \\
\text { In which way people... } \\
\text { What people do when... } \\
\text { How the people... } \\
\text { How do people understand the term "life-long } \\
\text { learning"? } \\
\text { What emotions does life-long learning evoke? } \\
\text { What are the pros and cons of life-long learn- } \\
\text { ing? }\end{array}$ \\
\hline
\end{tabular}

${ }^{3}$ The contents of this table are only basic assumptions that would definitely need to be developed and supplemented in the research project 


\begin{tabular}{|c|c|c|}
\hline $\begin{array}{l}\text { Stages of } \\
\text { marketing } \\
\text { research }\end{array}$ & Quantitative research & Qualitative research \\
\hline & $\begin{array}{l}\text { How many days should the training last? } \\
\text { What are the traits of the people who are } \\
\text { training? } \\
\text { Should classes be conducted on-line or off- } \\
\text { line, and which ones? }\end{array}$ & $\begin{array}{l}\text { What drives people to learn throughout their } \\
\text { lives? } \\
\text { How do people learn on their own (without } \\
\text { using organised or paid courses)? } \\
\text { How are sample course offers evaluated? } \\
\text { What are the features of the perfect course? } \\
\text { How are on-line and off-line courses per- } \\
\text { ceived? }\end{array}$ \\
\hline Hypothesis & $\begin{array}{l}\text { - about } 25 \% \text { of the respondents take ad- } \\
\text { vantage of additional training courses; } \\
\text { - respondents most often choose language } \\
\text { lessons; } \\
\text { - the most common reason for training } \\
\text { after graduation is the growing expecta- } \\
\text { tions of employers; } \\
\text { - women, people aged } 45-55 \text {, and those } \\
\text { with higher education are most often } \\
\text { trained; } \\
\text { - course groups should not exceed } 6 \text { peo- } \\
\text { ple. }\end{array}$ & Exploratory research—no hypotheses. \\
\hline $\begin{array}{l}\text { Research } \\
\text { methods }\end{array}$ & PAPI/ CAWI & Focus group interview. \\
\hline Sample & $\begin{array}{l}\text { Random quota selection, } 1,200 \text { households, } \\
\text { taking into account the structure of society } \\
\text { by sex, education and age. }\end{array}$ & $\begin{array}{l}\text { Total of } 6 \text { groups, } 6-7 \text { respondents in each } \\
\text { group; } \\
\text { purposeful selection (see subjective scope). }\end{array}$ \\
\hline $\begin{array}{l}\text { Methods of } \\
\text { analysis of } \\
\text { collected data }\end{array}$ & $\begin{array}{l}\text { Descriptive statistics measures, logistic re- } \\
\text { gression model, } \\
\text { cluster analysis } \\
\text { Computer software, e.g. SPSS, Statistica. }\end{array}$ & $\begin{array}{l}\text { Descriptive analysis, use of quotes, } \\
\text { Computer program from the group CAQDAS, } \\
\text { e.g. Atlas.ti. }\end{array}$ \\
\hline
\end{tabular}

Source: Own work based on (Kaczmarek, Olejnik, \& Springer, 2013; Schreier, 2012).

\subsection{Sustainable development in market research- ethical aspects}

The issues of market research in SD can be considered within the context of research agencies, as well as generally conducting research in a sustainable way. In the first case, the SD strategy of research agencies is considered. As an example, we may have a look at Amer Nielsen (AM) - one of the leading companies in the research sector. Amer Nielsen informs: "through responsible, sustainable business practices and our commitment to giving back, we care for the communities and markets where we live and operate our business. Our Global Responsibility \& Sustainability strategy at Nielsen includes all environmental, social and governance (ESG) 
issues that affect our business, operations, and all internal and external stakeholders (...)" (Making an uncommon impact, 2021). The AM research agency perceives its role broadly, in education, technology, human rights and preventing hunger (Figure 2). The employees also devote their time and skills to help non-profit organisations through pro bono work, in-kind giving and hands-on community projects. Nielsen measures the behaviour of consumers in more than 100 countries, and expertise helps nonprofits maximise their impact through improved outreach, messaging, effectiveness and efficiency.

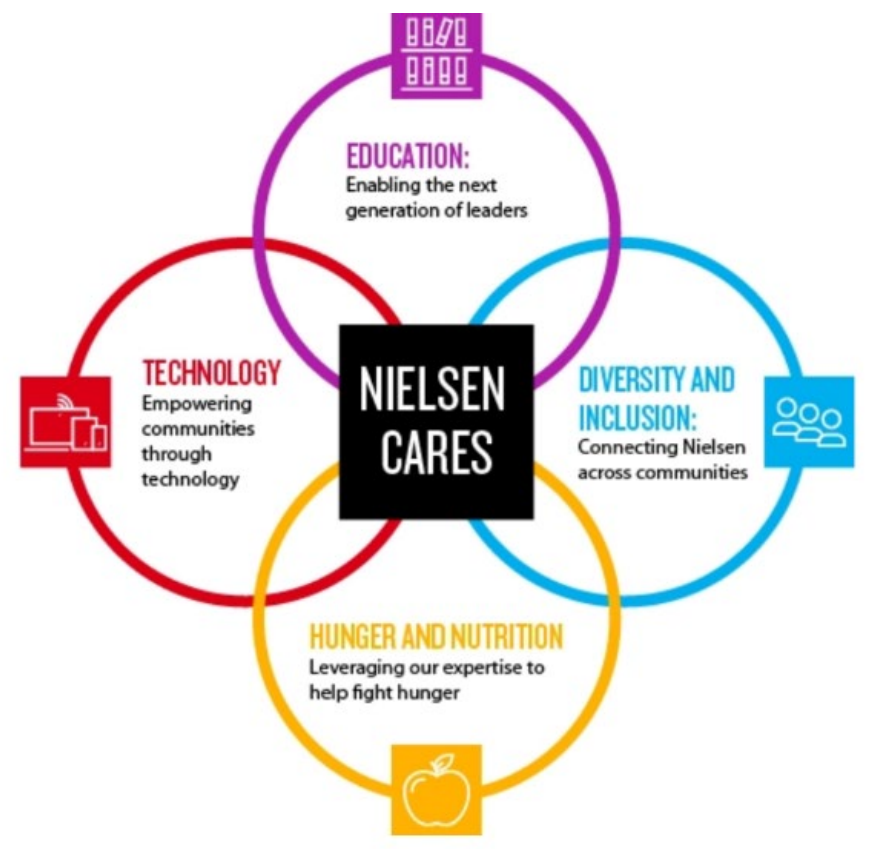

Figure. 2. Amer Nielsen Commitment

Source: (Making an uncommon impact, 2021).

The ethical issues have to be considered at all stages of market research. Participants of any research trial should be aware of its purpose, expected duration and procedures, any prospective research benefits, limits of confidentiality, such as data coding, disposal, sharing and archiving, and when confidentiality must be broken. As a result, conducting research often requires the consent of an ethics committee, especially when the research subject, trial or implemented method may significantly infringe the privacy and well-being of the respondent; for example:

- conducting research with the use of neuromarketing techniques requires determining whether the respondent meets the health criteria to take part in the study, although it is not of interest to the researchers; 
- conducting the study without consent to record the course of the study;

- scope and form of published information (i.e. non-financial reporting by companies-what kind of information is included and the way it is presented.

Acceptable research practices are defined in the Research Ethics Code. For instance, in the Esomar document entitled International Code on Market, Opinion and Social Research and Data Analytics, responsibilities to data subjects, clients, general public, research profession are described and available in a few languages (Esomar world research, 2016).

\section{Questions / tasks}

1. What methods of operationalisation regarding Corporate Social Responsibility do you know?

2. Find a research paper in which the authors present research findings on sustainable development and then:

a) discuss the research methodology used by the authors;

b) present the most important conclusions drawn from the research;

c) what other methods could be applied to conduct research in this area?

3. Analyse the European Union reports and compare SD indicators of selected countries. Analyse the scope and make conclusions. Give some recommendations as to what each country should do to improve the implementation of SD goals.

4. Taking secondary resources into account-select one of the groups of indicators from the SDG list. Compare them using data from selected EU countries. Formulate conclusions.

5. Which topics should also be included in the theme you selected in the question above? Why?

6. Taking the example of the study presented in Table 3 into account, answer the following questions:

a) Which research would you conduct first: qualitative or quantitative? Justify your answer.

b) What additional information would you need when analysing the baseline?

c) What are the advantages and disadvantages of using PAPI and CAWI in quantitative research? Which of these two methods would you choose and why?

d) What additional features should the respondents who will participate in FGI research have? How, apart from the type of town or city, do you differentiate individual groups of respondents?

7. Following the stages of primary market research steps-create the draft of a market research project connected with the topics listed below:

a) food waste by households; 
b) food waste by restaurants;

c) food waste by retailers;

d) renewable sources of energy;

e) how attitude towards energy from non-renewable sources can be changed;

f) innovations in ecological packaging;

g) building understanding of diversity;

h) consumer attitude towards second-hand products; and then, define: the research purpose and information needs, who could be a respondent in such research, what are the applicable test methods?

8. What ethical aspects should be taken into account when conducting research among children and adolescents on problems related to SD/CSR?

9. Go to websites of research agencies. On their websites, find codes of conduct/ ethical regulations referring to marketing research. Analyse them, then give some examples of how they are respected.

10. How can research agencies support SD in their business activity?

11. How would you rate the ethics of research based on household rubbish?

12. What kind of analysis can you apply regarding the examples of the scales in the 'Appendix'? Prepare a quantitative research project knowing that the questionnaire must contain one of the exemplary scales included in the 'Appendix'. Prepare the project according to the points presented in Table 2.

\section{References}

Alvarado-Herrera, A., Bigne, A., Aldas-Manzano, J., \& Curras-Perez, R. (2017). A scale for measuring consumer perceptions of Corporate Social Responsibility following the sustainable development paradigm. Journal of Business Ethics, 140(2), 243-262. https://doi.org/10.1007/s10551-015-2654-9

Bougie, R., \& Sekaran, U. (2020). Research methods for business. A skill building approach. Wiley.

Churchill, G. A., \& Iacobucci, D. (2018). Marketing research. Methodological foundations, 12th ed. Nashville: Earlie Lite Book, Inc.

Creswell, J. W., \& Creswell, J. D. (2018). Research design: Qualitative, quantitative, and mixed methods approaches. London: Sage Pubn.

Esomar world research. (2016). ICC/ESOMAR International code on market, opinion and social research and data analytics. Retrieved from https://www.esomar.org/uploads/public/knowledge-and-standards/codes-and-guidelines/ICCESOMAR_Code_English_.pdf

Hofhuis, J., van der Zee, K. I., \& Otten, S. (2015). Measuring employee perception on the effects of cultural diversity at work: development of the benefits and threats of diversity scale. Qual Quant, 49, 177-201. https://doi.org/10.1007/s11135-013-9981-7

Making an uncommon impact. Retrieved October 11, 2020 from https://www.nielsen.com/us/en/ about-us/global-responsibility-and-sustainability/nielsen-cares/

Kaczmarek, M., Olejnik, I., \& Springer, A. (2013). Badania jakościowe. Metody i zastosowania. Warszawa: CeDeWu.

McDaniel, C., \& Gates, R. (2018). Marketing research, $11^{\text {th }}$ ed. Wiley. 
Neuman, W. L. (2014). Social research methods: qualitative and quantitative approaches. Pearson.

Parris, T. M., \& Kates, R. W. (2003). Characterizing and measuring sustainable development. Annu. Rev. Environ. Resour., 28(13.1-13.28).

Poland OECD countries. (2019, June 28). Retrieved from https:/github.com/sdsna/2019GlobalIndex/ blob/master/country_profiles/Poland_SDR_2019.pdf

Prologis ESG Impact Report. (2019). Creating value beyond real estate. Retrieved from https://www. prologis.com/sites/corporate/files/documents/2020/06/2019-prologis-esg-impact-report.pdf

Prologis liderem zrównoważonego rozwoju w rankingu Global 100. Retrieved February 5, 2020 from https://www.logistyka.net.pl/aktualnosci/item/90783-prologis-liderem-zrownowazonego-rozwoju-w-rankingu-global-100

Quazi, A. M., \& O’Brien, D. (2000). An empirical test of a cross-national model of Corporate Social Responsibility. Journal of Business Ethics, 25, 33-51.

Quoquab, F., Mohammad, J., \& Sukari, N. N. (2019). A multiple-item scale for measuring "sustainable consumption behaviour" construct: Development and psychometric evaluation. Asia Pacific Journal of Marketing and Logistics, 31(4), 791-816.

Schreier, M. (2012). Qualitative content analysis in practice. London: SAGE Publications Ltd.

Singhapakdi, A., Vitell, S. J., Rallapalli, K. C., \& Kraft, K. L. (1996). The perceived role of ethics and social responsibility: A scale development. Journal of Business Ethics, 15, 1131-1140.

Sustainable Development Goals. (2019). Retrieved from https://sustainabledevelopment.un.org/ globalsdreport

The Sustainable Development Report. (2019). Retrieved from https://sdgindex.org/reports/sustainable-development-report-2019/

United Nations. (2020). Sustainable Development Goals. SDG indicators. Retrieved from https://unstats. un.org/sdgs/indicators/indicators-list

UNSTAT (United Nations Statistics Division). (2020). Global indicator framework for the Sustainable Development Goals and targets of the 2030 Agenda for Sustainable Development. Retrieved October 11, 2020 from https://unstats.un.org/sdgs/indicators/Global\%20Indicator\%20Framework\%20 after\%202020\%20review_Eng.pdf 


\section{Appendix}

Regardless of whether quantitative marketing research is carried out by internal services or research agencies-it should be verified whether there are ready-to-use tools to research the chosen problem. There are a number of scales that can be applied for $\mathrm{SD}$ or CSR research, and thanks to standardised tools, it is possible to compare the obtained research results between departments, divisions, enterprises or countries.

\section{Example 1. Perceived Role of Ethics and Social Responsibility scale (PRESOR)}

1. Being ethical and socially responsible is the most important thing a firm can do.

2. Bending and breaking the rules is acceptable if a firm is making a profit.

3. The ethics and social responsibility of a firm is essential to its long-term profitability.

4. Overall effectiveness of a business can be determined, to a great extent, by the degree to which it is ethically and socially responsible.

5. To remain competitive in a global environment, businesses will have to disregard ethics and social responsibility.

6. Social responsibility and profitability can be compatible.

7. Business ethics and social responsibility are critical to the survival of a business enterprise.

8. A firm's first priority should be employee morale.

9. Businesses have a social responsibility beyond making profit.

10. If the survival of a business enterprise is at stake, then ethics and social responsibility must forgotten.

11. Efficiency is much more important to a firm than whether or not the firm is seen as ethically or socially responsible.

12. Good ethics is often good business.

13. If the stockholders are unhappy, nothing else matters.

Source: (Singhapakdi, Vitell, Rallapalli, \& Kraft, 1996).

\section{Example 2. Corporate Ethical Values scale (CEV)}

1. Managers in my company often engage in behaviours that I consider unethical.

2. In order to succeed in my company, it is often necessary to compromise one's ethics.

3. Top management in a company has let it be known that under no conditions will unethical behaviour be tolerated.

4. If a manager at my company is discovered to have engaged in unethical behaviour, primarily resulting in personal gain (rather than corporate gain), she/he will be promptly reprimanded.

5. If a manager at my company is discovered having engaged in unethical behaviour, primarily resulting in corporate gain (rather than personal gain), she/he will be promptly reprimanded.

Source: (Quazi \& O’Brien, 2000).

\section{Example 3. Scale to measure sustainable consumption behaviour}

1. I always try hard to reduce miss-use of goods and services (e.g. I switch off lights and fan when I am not in the room).

2. I recycle daily newspapers (e.g. use it in pet's litter box, etc.).

3. I avoid being extravagant in my purchases. 
4. I avoid over use/consumption of goods and services (e.g. print only when needed).

5. I reuse paper by writing on the other side.

6. While dining at a restaurant, I order food(s) only in the amount that I can eat to avoid wasting food.

7. I choose to buy product(s) with biodegradable containers or packaging.

8. I do not like to waste food or beverages.

9. I recycle my old stuff in every possible way (e.g. distribute old clothes among those less fortunate).

10. I reuse shopping bag(s) every time I go shopping.

11. I plan carefully before I purchase a product or use a service.

12. I care for the natural environment.

13. I use eco-friendly products and services.

14. I purchase and use products which are environmental-friendly.

15. I often pay extra money to purchase environmentally-friendly products (e.g. organic food).

16. I am concerned about the shortage of natural resources.

17. I prefer to use paper bags since they are biodegradable.

18. I love our planet.

19. I always remember that my excess consumption can create hindrance for the future generation to meet their basic needs.

20. I care for fulfilling the needs of the next generation.

21. I often think about the future generation's quality of life.

22. I try to control my desire of excessive purchase for the sake of future generations.

23. I am concerned about the future generation.

24. I try to minimise excess consumption for the sake of preserving environmental resources for the future generation.

Source: (Quoquab, Mohammad, \& Sukari, 2019).

\section{Example 4. Items in the CSRConsPerScale scale}

In my opinion regarding society, [organisation's name] is really:

1. trying to sponsor educational programmes;

2. trying to sponsor public health programmes;

3. trying to be highly committed to well-defined ethical principles;

4. trying to sponsor cultural programmes;

5. trying to make financial donations to social causes;

6. trying to help to improve quality of life in the local community.

In my opinion regarding the environment, [organisation's name] is really:

1. trying to sponsor pro-environmental programmes;

2. trying to allocate resources to offer services compatible with the environment;

3 . trying to carry out programmes to reduce pollution;

4. trying to protect the environment;

5. trying to recycle its waste materials properly;

6. trying to use only the necessary natural resources.

In my opinion regarding the economy, [organisation's name] is really:

1. trying to maximise profits in order to guarantee continuity;

2. trying to build solid relationships with its customers to assure long-term economic success;

3. trying to continuously improve the quality of the services that it offers;

4. trying to have a competitive pricing policy;

5. trying to always improve its financial performance;

6. trying to do its best to be more productive.

Source: (Alvarado-Herrera, Bigne, Aldas-Manzano, \& Curras-Perez, 2017). 
Example 5. Cultural diversity on the workplace scale (BTDS)

\section{Benefits of cultural diversity}

Understanding diverse groups in society ...

...enables us to adjust our policies to different groups in society;

...gives us better insight into the needs of different groups in society;

...allows us to reach a larger part of the community with our policy;

...helps us better understand new developments in society.

Creative potential...

...makes us better at solving complex problems;

...enables us to come up with more original ideas;

...makes us more innovative;

...leads colleagues to learn more from each others' knowledge and experience.

Image of social responsibility....

...is good for our image towards the outside world;

...makes the outside world look at our department in a more positive way;

...makes all groups in society look at our organisation in a more positive way;

...is good for our department's image amongst minority groups in society.

Job market...

....is needed to fill all vacancies in our department;

...is necessary for recruiting enough new personnel;

...leads us to have more choices when recruiting and selecting new personnel;

...is necessary for anticipating changes in the job market.

Social environment....

...has a positive effect on work atmosphere;

...leads to a pleasant work environment;

...is fun;

...makes this an interesting place to work.

Threats of cultural diversity

Realistic threats....

...lead to fewer career opportunities for the majority of members;

...diminish the status regarding the majority of employees;

....reduce the attention given to the needs regarding the majority of members;

...cause the majority of employees to feel less recognised.

Symbolic threats....

...cause friction between colleagues with different norms and values;

...cause the department's culture to radically change;

...lead to a situation in which the majority of members are forced to adjust;

...force employees to adjust to a different culture.

Intergroup anxiety...

...makes it more difficult for colleagues to understand each other;

...leads to uncomfortable situations;

...makes it hard to judge what others are thinking;

...causes insecurity in interactions with co-workers.

Productivity loss....

...causes managers to spend more time on individual coaching;

...makes our department difficult to manage;

...makes our work processes run less smoothly;

...reduces the overall quality of employees

Source: (Hofhuis, van der Zee, \& Otten, 2015). 


\title{
4.
}

\section{SUSTAINABILITY IN HUMAN RESOURCE MANAGEMENT}

\author{
Magdalena Stefańska \\ Poznań University of Economics and Business
}

\begin{abstract}
The concept of sustainability is referred to the basic functions of human resources (HR) recruitment, motivation, assessment and control. They should embrace sustainability, not just for organisational effectiveness and long-term economic benefits, but also for ethical reasons. Owing to SHRM, the awareness and behaviour of the whole organisation may strongly express SD goals in planning and implementing the whole corporate strategy. Frequently, the term 'sustainable practices' in SHRM is congruent with CSR. The main goal of the chapter is to explain how Sustainable Development Goals can be implemented in human resource management (HRM) and translated into sustainable human resource management (SHRM).
\end{abstract}

Keywords: human resource management, sustainability, sustainable human resource management. 


\section{4.l. Meaning of sustainability in human resource management}

Human Resource Management (HRM) is a broad term referring to the activities associated with the management of people who do the work of organisations (Ahammad, 2017). Human resource strategies are designed to improve organisational performance and measures the impact of these strategies on it. As one of the functional strategies that follows corporate mission and vision-it has to be integrated with organisational strategic objectives and reflect organisational context (culture). And last but not least, HRM activities should improve organisational performance and effectiveness. Human capital management is to serve, among others, in (Armstrong, 2000; Romanowska, 2011):

- achieving an organization's goals;

- acquiring and retaining qualified, committed and well-motivated employees in a company;

- improving and developing people's innate capabilities through training and clearing career paths;

- building good atmosphere, particularly in relations between employees, and between employees and superiors;

- creating conditions for such a form of work that will contribute to achieving synergistic effects;

- helping a company maintain balance and adapt to the needs of various interest groups;

- guaranteeing equal treatment, proper and fair evaluation and appropriate rewarding of employees and managers for the contribution and results of their work;

- taking the diversity of employees 'needs regarding the preferred style of work and employees' aspirations into account;

- providing all employees and managers with equal opportunities;

- adopting flexible employee management rules, based on concern for people, fairness and transparency;

- maintaining and improving the physical and mental condition of employees.

- If the above goals were combined with the concept of SD, this would mean, among others (UNSTAT, 2020):

- promoting development-oriented policies that support productive activities, decent job creation, entrepreneurship, creativity and innovation, and encouraging the formalisation as well as growth of micro-, small- and medium-sized enterprises, including through access to financial services;

- achieving full and productive employment and decent work for all women and men, including young people and persons with disabilities, and equal pay for work of equal value. 
The term sustainable HRM (SHRM) has not been used for a long time. It is mainly implemented to identify social and human outcomes contributing to a sustainable organisation. Incorporating the SD concept reflects goals, which are dedicated to the place of work and workers. From a business perspective, the ultimate objective of the SDGs is to establish "sustainable, innovative and people-oriented" economies that improve employment opportunities, in particular, for the young generation and women. HR sustainability has been described as a symbol of an integrated, long-term people management approach, resulting in sustained business performance and employee benefits (Wilkinson, Hill, \& Gollan, 2001). The mission of organisations is to ensure that their workforces are healthy and well-educated, and to nurture the awareness and proficiencies required to create productive employees and proactive citizens contributing to society (Chams \& García-Blandón, 2019).

The objective of SHRM is to reach organisational targets, while striking a balance between business growth and the preservation of environmental resources (Jennings \& Zandbergen, 1995; Starik \& Rands, 1995). SHRM places emphasis on developing an innovative workplace with internal and external social involvement, increasing awareness and responsibility towards environmental preservation, and improving the distribution and consumption of resources to promote organisational success in a competitive environment (Kramar, 2014). Sustainable HRM concentrates on demonstrating sincerity towards employees, providing a decent work environment and conditions, development opportunities and being attentive to employees' physical and psychosocial well-being at work (Wikhamn, 2019).

\subsection{Sustainability in human resource management- recruitment and selection}

The demand for new employees arises due to many reasons-with leaving the workplace by present employees, the development of new products and services, entering new markets, investing in new plants, etc. As a result, forecasting the number of employees' required knowledge on:

- demand for the products;

- productivity level of the staff;

- objectives of the business.

Forecasting the skills required:

- following technological changes;

- flexible and multi-skilled staff.

In the sustainable recruitment approach, candidates are not treated as commodities needed to solve short-term needs of an organisation, but as a long-term investment to ensure its development and continuity. The recruiters have to know the type of position-will it be contracted or temporary staff? They also need to 
analyse whether alternative solutions will be more effective. As an example, one may consider outsourcing, which is a contractual agreement between an employer and an external third-party provider, whereby the employer transfers the management of and responsibility for certain HR functions to the external provider. Responsibility during the recruiting process is connected with transparency of procedures, conditions and protection of diversity, and in accordance with the policy against discrimination.

Employee recruitment is carried out by internal recruitment among employees already employed, or external recruitment-searching for employees by the organisation or with the participation of a specialised recruitment company. The whole process may take place in several stages, and its duration depends on the position and expectations of the employer (Yakubovich \& Lup, 2006):

- announcement of recruitment (job description, description of the position, responsibilities), description of the requirements (obligatory and additional), working conditions, place in the hierarchical structure, how the job will be assessed and performance measures. In many countries, it is forbidden to mention age or gender of the candidate in an announcement. Furthermore, it is not acceptable to add a photo or information about marital status;

- getting acquainted with the documents sent by the applicants (online or offline);

- pre-selection-initial assessment and selection of candidates who will be invited to the next stages of the recruitment process;

- meetings aimed at becoming better acquainted with the candidates;

- meeting with the person responsible for the candidate's target position;

- interviewing candidates (not only getting to know the candidate, but also presenting the company, its values and organisational culture);

- selection of the best candidate;

- employment-boarding.

In order to improve, but also to make the recruitment processes more sustainable, online recruitment is increasingly being used, where candidates complete standardised forms on the Internet. Often, due to the large number of candidates for certain positions, artificial intelligence is involved in that process to initially verify the list of candidates. This usually refers to basic positions, which do not require special skills from candidates.

One of the methods used to match candidates to the positions and organisational culture is recruitment through an assessment centre (AC). Due to costs and the timeconsuming process, while using this method-it is often applied to a limited group of candidates-middle- or higher-level management positions. The process of recruitment consists of a few stages in which skills and personal competences of candidates are verified by means of different tools (for example, individual work or in teams). This procedure increases the probability that both the employee and organisation will be satisfied. Each position requires a different set of competences and predispositions assessed in that process to avoid disappointment or lack of satisfaction. The 
decision who will be employed brings about long-term effects-the company invests in a newly-employed person, who after a few weeks of adaptation, will be a fully productive and integrated employee. The employee-will invest knowledge and skills to confirm that she/he is the best person for the position. That is why the recruitment process may take longer-to compare candidates and choose a superior applicant.

A frequent practice in the recruitment process is reaching for the recommendations of candidates for a given position.

What differs traditional recruitment from SHRM? The following recommendations for sustainability in recruitment and selection were described by Jepsen and Grob (2015):

- paperless processes;

- technology to reduce travel;

- green interviews (during an interviews, presenting an environment that demonstrates the sustainability practices of the organisation);

- in-house recruitment;

- incorporating sustainability practices into the job design;

- sustainability competences;

- flexibility to encourage applicant diversity;

- community engagement;

- induction demonstrating sustainability;

- monitoring and reporting sustainability targets.

Recruitment maybe connected with some other negative phenomena, such as nepotism and discrimination. As far as nepotism is concerned, family or any closelyrelated people are employed, but not on the basis of their qualifications and skills.

Other problems faced by candidates are connected with discrimination due to gender, age, family status, religion or opinions. That is why the objective criteria are applied to equal chances for all candidates. In some societies, it is difficult to overcome traditional thinking about the role of women and men. Also, age is often perceived as a barrier-one of the stereotypes is that younger means inexperienced, while older means experienced but less open to innovations and less flexible. In the long-term, both nepotism and discrimination negatively affect a company-they influence relations among employees and reduce trust in managers whether their managerial decisions are objective and fair or not.

\subsection{Employer branding and sustainability}

Seeking specific, qualified employees for any position has always been a real challenge for all companies in the modern economy. Since employees have become part of the businesses' overall brand image, employers are responsible not only for product brands, but also for those corporate. 
The employer brand can be defined as "the package of functional, economic and psychological benefits provided by employment and identified with the company employing workers" (Ambler \& Barrow, 1996). The main role of EB is to provide a coherent framework for management, to simplify and focus priorities, increase productivity and improve recruitment, retention and commitment. Defining employer branding similarly as "a targeted, long-term strategy to manage the awareness and perceptions of employees, potential employees, and related stakeholders with regards to a particular firm" (Sullivan, 2004). Through employer branding, the organisation expects to be differentiated from other companies in competition for the best present and future employees, by highlighting the unique aspects of a firm as an employer. Employer branding in the context of recruitment is the package of psychological, economic and functional benefits that potential employees associate with employment at a particular company (Wilden, Gudergan, \& Lings, 2010).

Employer branding brings some advantages to companies:

- reduced cost of employee acquisition;

- improved employee relations;

- increased employee retention, higher loyalty.

Knowledge of them benefits organisations that want to create an attractive and competitive employer brand. To do that, an organisation has to create EVP-Employee Value Proposition, which is the indication of the main attributes of a given company and benefits that would result from starting work at it. This conveys "value proposition", which consists of the organisation's culture, systems, attitudes, and employee relationships, along with encouraging people to embrace and share goals of success, productivity and satisfaction, both on individual and professional levels. As far as sustainability-oriented organisations are concerned, those values may be connected with areas described in the 3P model-people, planet, profit-protection of the natural environment and protecting human rights. Sustainable organisations communicate their attitude towards the brand to society, the natural environment and the way of achieving economic goals in a sustainable way (Jepsen \& Grob, 2015). It worth adding that according to the Randstad Report (2018), employees expect, among others: fair salary and benefits, job security, work-life balance, work atmosphere, career progression (...).

SDGs are often implemented in organisations by means of CSR tools (Stefańska, 2018). Undoubtedly, CSR tools are concentrated on employees to strengthen a positive internal image, as well as to transfer the satisfaction from an employee to the outside environment. This is indicated, among others, by Korschun, Bhattacharya and Swain (2014) and Lin, Tsai, Joe, \& Chiu (2012), according to whom:

- CSR can indirectly strengthen the company's ability to meet the needs of buyers through the observation and behaviour of employees; 
- customers' belief regarding the social involvement of employees gives rise to greater acceptance of lower-/worse-quality services;

- thanks to CSR, it is possible to achieve a greater level of employee orientation towards meeting the needs of customers;

- socially engaged enterprises attract better employees, stemming from, among other factors, the employees' expectations to be identified with organisations having a positive image.

The process of employer brand creation includes the following stages (Stefańska \& Bilińska-Reformat, 2020):

- identification of competitors and criteria for perceiving competitors' brands, as well as what associations and emotions they elicit to indicate competitors' strengths and weaknesses;

- identification of own image and key values attributed to the brand of the organisation (for example: ecological orientation, fair treatment and respect of employees, employee-friendly atmosphere and encouraging initiatives, transparent policy towards employment and professional advancement);

- identification of expectations regarding potential and current employees (organisation which is transparent, creative, respectful, ecologically oriented);

- defining the basis of values on which employer brand image will be built (EVP);

- selection of appropriate tools and communication channels for employer brand image;

- evaluation of action efficiency and effectiveness in terms of the level of target achievement and comparison of results to incurred costs.

The policy of creating an EB exercised in an organisation is focused on 2 target groups: future employees and already employed persons (Stefańska \& Bilińska-Reformat, 2020, Tumasjan, Kunze, Bruch, \& Welpe, 2020). The different situation of both groups inspires diversification of the tools used for building the employer brand. Studies conducted in the first group are now focused on the communication channels, the use of the Internet, especially, social media. In the case of already employed workers, it supports building loyalty, commitment or the motivation to work, career and talent management, while, at the same time, discouraging employees from changing their workplace. It also allows workers to stay active on the labour market longer.

There is an expectation to work for sustainable organisations among younger generations-generation $\mathrm{Z}$ and also younger representatives of generation $\mathrm{Y}$. For them, the fact that a company implements SD goals, and carries out a transparent policy of employment and development for employees, they are encouraged to work for such organisations and to be loyal. 


\subsection{Motivation and sustainability in human resource management}

Motivation is what makes people act. An organisation can have strong influence on employees' motivations-people work to satisfy their needs, however, what type of needs they are-that depends.

Theories of motivation usually do not directly use such terms as: sustainable development or sustainability. But when one looks deeper - they strongly refer to such values as respect, safety, well-being, engagement, transparency, diversity and others-as values which build a positive work environment and motivate people. And these are the core values promoted by SD.

According to Maslow (1943), people cannot think about development and satisfying higher needs if their physiological ones are not satisfied. Also the need for safety and self-protection, if not satisfied - does not allow to move onto higher aspirations-affiliation and belonging, as well as status, self-esteem and self-actualisation (Maslow's hierarchy of needs).

Herzberg's two-factor theory, also known as motivation-hygiene theory, was originally intended to address employee motivation and recognised 2 sources of job satisfaction. He argued that motivating factors influence job satisfaction because they are based on an individual's need for personal growth: achievement, recognition, work itself, responsibility and advancement. On the other hand, hygiene factors, which represented deficiency needs, defined the professional context and could make individuals unhappy with their job: company policy and administration, supervision, salary, interpersonal relationships and working conditions (Haque, Haque, \& Islam, 2014).

In Skinner's operant conditioning theory, positive reinforcement is identified as promoters that increase the possibility of the desired behaviour's repetition: praise, appreciation, a good grade, trophy, money, promotion or any other reward (McLeod, 2018).

Locke's goal-setting theory, an integrative model of motivation, allows to view goals as key determinants of behaviour. The goal-setting theory stresses goal specificity, difficulty and acceptance, further providing guidelines for their incorporation into incentive programmes and management by objective (MBO) techniques in many areas (Locke \& Latham, 2002).

Douglas McGregor proposed 2 theories, theory X and theory Y, to explain employee motivation and its implications for management. In his opinion, one may find employees who avoid work (theory $\mathrm{X}$ ) and dislike responsibility, and employees who enjoy work and exert effort when they have control in the workplace (theory Y). He recommended that to motivate employees who avoid work, the company needs to enforce rules and implement punishment. For employees positively driven to work, management must develop opportunities for them to take on responsibility and show creativity as a way of motivation (Kopelman, Prottas, \& Davis, 2008). 
Adams' equity theory is about the balance between the effort an employee puts into his/her work (input), and the result she/he achieves in return (output) (Mulder, 2018). Input includes hard work, loyalty, social skills, experience, knowledge, efforts and enthusiasm. Output can be: financial-alike salary, or non-financial-such as recognition and responsibility. A good example is empowerment-proof of trust towards an employee. The expected balance between input and output occurs when an employee feels satisfied and motivated, contributing to productivity. According to this researcher, employees view being treated fairly and equally to be of great significance. This ensures that they will be motivated at work. It is treating various employees differently and unfairly that leads to bad blood and damaging people's motivation.

In the selected theories presented above, there is no direct mention of sustainability. However, they allow to underline the fact that such values as respect, engagement, diversity, decent work conditions and ethical standards of employees are necessary for the high engagement and commitment of employees.

Nowadays, professional burnout, stress at work, health problems or difficulties in balancing work-related duties and private life are extremely relevant challenges. Such a situation leads to HRM rethinking if companies are willing to have employees when conducting business in the future. Among good practices in SHRM, the following may be found:

- contract or fair service contract employment;

- regulations against any form of discrimination;

- whistle-blowing policies;

- transparency-especially in recruitment and assessment;

- equipment to facilitate physical work;

- fairly paid overtime;

- diversity policies;

- responsible policy of redundancy;

- internship (paid).

Employees can be motivated by means of both material and non-material benefits. Of course, salary determines one's decision about the place of work and employer. In previous decades, specific solutions, e.g. offering health-care, child-care facilities or kindergartens for employees' children, sports vouchers or voluntary pension systems are more often indicated among financially-based tools (Olejnik \& Stefańska, 2020).

No less important is the form of employment as a motivating element to work at a given company. One of the elements of building employee safety is an employment contract-long-term or indefinite. Temporary contracts leave employees with an uncertainty about their future. In addition, they lose some employment rights, and in the situation of wanting to obtain a loan, such an employee is considered inferior. As a result, full-time employment is a source of stability. However, part-time and 
temporary employment contracts result from the fact that the employee is hired to perform specific tasks or as a replacement and, after termination of the contract-it most likely will not be renewed. This type of employment is suitable for people looking for temporary work.

\subsection{Remote work and sustainable development}

Among problems faced by employers who search for the most talented candidates, is low willingness of applicants to move from their current place of residence to the place of work (relocation). Mobility is often one of the conditions, especially in international organisations or organisations with facilities at different locations in the country or around the world. Long distances seems to be an obstacle in some types of jobs, however, they create new chances for people whose duties do not require attendance at the office. To secure "work-life balance", employers offer candidates the possibility of remote work-if adoptable for some types of jobs. It is worth mentioning that the problems are not equally important for workers from different generations, different cultures or with varying marital status. One of the solutions is remote work.

With the development of ICT, the interest in remote work has increased. Its spread was caused by the COVID-19 pandemic, forcing many workplaces to make employees work remotely-from home. Tele-working comes with certain advantages-less time is spent commuting to work, more time is spent at home with one's family. Time is used efficiently. On the other hand, the lack of direct contact with colleagues, superiors or clients may weaken the relationships between employees. The possibilities of carrying out some tasks based on teamwork are also limited, although the barrier may lie more in being used to face-to-face meetings than online cooperation. The tools used for remote work largely replace direct contact, but also lead to greater formalisation. Nonetheless, it is worth adding that remote work also leads to the reduction of utilised materials, because communication is based, to a greater extent, on messages in electronic form than on paper.

\subsection{Reduction of employment in responsible organisations}

Human resource management is also linked to employment reduction policy. The reasons for limiting the number of employees lie both in the part of the company and external factors: change of strategy, organisational structure, resource optimisation, resigning from certain products, management errors and unfavourable 
financial situation, closing or relocation of plants to other places-reasons on the part of the organisation. In contrast, economic crises, natural disasters, legislative and technological changes also become a reason for reducing employment.

The procedures for dismissal of employees are specified in the Labour Code, including notice periods or severance pay. In the case of collective redundancies, they are also subject to negotiations between management boards of companies and trade unions. Nevertheless, companies that implement a Corporate Social Responsibility strategy and build positive relationships with employees introduce additional solutions to help employees going through a change. These include, among others:

- employee re-training programmes;

- job search assistance for departing employees;

- clearance;

- psychological support;

- mentoring programmes.

\section{Questions / tasks}

1. What is sustainable human resource management? What are the differenceswhen compared to human resource management?

2. One of the SD goals is defined in the following way: the SD goal is to promote sustained, inclusive and sustainable economic growth, full and productive employment and decent work for all. What does this mean to you?

3. How can SD goals be carried out in the field of recruitment?

4. What do you think about the participation of artificial intelligence in employee recruitment processes?

5. Is hiring an employee for a given position on the basis of being recommended by another employee from the organisation a good practice?

6. Discuss stereotypes in recruitment. How can they be overcome?

7. Is sustainability in corporate recruitment strategy an important factor influencing candidates?

8. Find 2 announcements for the same type of position on different websites. Do you see any similarities? Differences? Which one seems to be more sustainable? Do they mention sustainability in any form?

9. Define the EVP of a sustainable company and find example(s).

10. Your application for a job was accepted by 2 companies. You have to choose-one with higher salary at a company which does not offer EVP based on sustainability, and the other, at which their EVP is based on sustainability, but the salary is lower by about $8-10 \%$ (with the option of an increase during the next year). Which would you choose-explain.

11. Explain the theories of motivation. 
12. Minimum wage was set up to protect employees interests. Does it work?

13. Do benefits offered by employers influence engagement and loyalty?

14. What is empowerment? How does it influence employee engagement?

15. How do job enlargement and job enrichment influence employee motivation?

16. Many countries test the model of basic unconditional income. What do you think about it in the context of needs and motivations? (see: https://www. dw.com/en/basic-income-germany-tax-free/a-54700872; and also https:// www.ifo.de/DocDL/CESifo-Forum-2018-3-de-wispelaere-halmetois-pulkkaunconditional-basic-income-september.pdf).

17. One of the factors influencing employment are parities. According to some candidates, this is a factor that causes unequal competition for a given position. What is your opinion on the subject? Discuss the pros and cons.

18. What knowledge, skills and social competences are particularly desirable in future employees?

19. Many jobs will disappear from the market in coming years. Will newly created jobs in other sectors balance this process? How can the quality of life among people who are unemployed and do not have the competences expected by many employers be taken care of?

\section{References}

Ahammad, T. (2017). Personnel management to Human Resource Management (HRM): How HRM functions?. Journal of Modern Accounting and Auditing, 13(9), 412-420. https://doi. org/10.17265/1548-6583/2017.09.004

Ambler, T., \& Barrow, S. (1996). The employer brand. Journal of Brand Management, 4(3).

Armstrong, M. (2000). Zarządzanie zasobami ludzkimi. Kraków: Oficyna Ekonomiczna.

Becker, A. (2020). Money for nothing: Germany starts basic income experiment. Retrieved April 20, 2021 from https://www.dw.com/en/basic-income-germany-tax-free/a-54700872

Chams, N., \& García-Blandón, J. (2019). On the importance of sustainable human resource management for the adoption of sustainable development goals. Resources, Conservation \& Recycling, $141,102-109$.

Haque, M. F., Haque, M. A., \& Islam, M. S. (2014). Motivational theories -A critical analysis. ASA University Review, 8(1), 61-68.

Jennings, P. D., Zandbergen, P. A. (1995). Ecologically sustainable organizations: An institutional approach. Academy of Management Review, 20(1015). https://doi.org/10.2307/258964

Jepsen, D. M., \& Grob, S. (2015). Sustainability in recruitment and selection: Building a framework of practices. Journal of Education for Sustainable Development, 9(2), 160-178.

Kopelman, R., Prottas, D., \& Davis, A. (2008). Douglas McGregor's Theory X and Y: Toward a construct-valid measure. Journal of Managerial Issues, 20, 255-271.

Korschun, D., Bhattacharya, C. B., \& Swain, S. D. (2014). Corporate Social Responsibility, customer orientation, and the job performance of frontline employees. Journal of Marketing, 78, 20-37.

Kramar, R. (2014). Beyond strategic human resource management: is sustainable human resource management the next approach?. The International Journal of Human Resource Management, 25(8), 1069-1089. https://doi.org/10.1080/09585192.2013.816863 
Lin, C.-P., Tsai, Y.-H., Joe, S.-W., \& Chiu, C.-K. (2012). Modeling the relationship among perceived corporate citizenship, firms' attractiveness, and career success expectation. Journal of Business Ethics, 105.

Locke, E. A., \& Latham, G. P. (2002). Building a practically useful theory of goal setting and task motivation: A 35 year odyssey. American Psychologist, 57(9), 705-717. https://doi.org/10.1037/0003-066 X.57.9.705

Maslow, A. H. (1943). A theory of human motivation. Psychological Review, 50, 370-396.

McLeod, S. A. (2018). Skinner - operant conditioning. Simply Psychology. Retrieved April 25, 2021 from https://www.simplypsychology.org/operant-conditioning.html

Mulder, P. (2018). Adams equity theory. Retrieved April 20, 2021 from https://www.toolshero.com/ psychology/adams-equity-theory/

Olejnik, I., \& Stefańska, M. (2020). Integration of the employee pension programs with CSR. In K. Bachnik, M. Kaźmierczak, M. Rojek-Nowosielska, M. Stefańska, \& J. Szumniak-Samolej (Eds.), CSR in contemporary Poland. Palgrave Macmillan.

Randstad Raport. (2018). Employer Brand Research Global Report.

Romanowska, M. (2011). Zarządzanie kapitałem ludzkim. Zeszyty Naukowe Uniwersytetu Szczecińskiego, 685. Seria: Finanse, Rynki Finansowe, Ubezpieczenia, 46. Szczecin.

Starik, M., \& Rands, G. P. (1995). Weaving an integrated web: Multilevel and multisystem perspectives of ecologically sustainable organizations. Academy of Management Review, 20(908). https://doi. org $/ 10.2307 / 258960$

Stefańska, M. (2018). The relationship between the perception of the company and employee attitude in the context of CSR-The results of an empirical study. Research Papers of Wrocław University of Economics, 520.

Stefańska, M., \& Bilińska-Reformat, K. (2020). Employer branding and Corporate Social Responsibility. In K. Bachnik, M. Kaźmierczak, M. Rojek-Nowosielska, M. Stefańska, \& J. Szumniak-Samolej (Eds.), CSR in contemporary Poland (pp. 153-171). Palgrave Macmillan.

Sullivan, J. (2004). Eight elements of a successful employment brand. ER Daily. In K. Backhaus, \& S. Tikoo, Conceptualizing and researching employer branding. Career Development International, 9(4/5), 501-517.

Tumasjan, A., Kunze, F., Bruch, H., \& Welpe, I. M. (2020). Linking employer branding orientation and firm performance: Testing a dual mediation route of recruitment efficiency and positive affective climate. Human Resource Management, 59, 83-99. https://doi.org/10.1002/hrm.21980

UNSTAT (United Nations Statistics Division). (2020). Global indicator framework for the Sustainable Development Goals and targets of the 2030 Agenda for Sustainable Development. Retrieved October 11, 2020 from https://unstats.un.org/sdgs/indicators/Global\%20Indicator\%20Framework\%20 after\%202020\%20review_Eng.pdf

Yakubovich, V., \& Lup, D. (2006). Stages of the recruitment process and the referrer's performance effect. Organization Science, 17(6), 710-723. http://dx.doi.org/10.1287/orsc.1060.0214

Wikhamn, W. (2019). Innovation, sustainable HRM and customer satisfaction. International Journal of Hospitality Management, 76, 102-110.

Wilden, R. M., Gudergan, S., \& Lings, I. N. (2010). Employer branding: strategic implications for staff recruitment. Journal of Marketing Management, 26(1-2), 56-73.

Wilkinson, A., Hill, M., \& Gollan, P. (2001). The sustainability debate. International Journal of Operations \& Production Management, 21(12), 1492-1502. 



\title{
5.
}

\section{SUSTAINABLE DEVELOPMENT IN ACCOUNTING}

\author{
Marzena Remlein \\ Poznań University of Economics and Business
}

\begin{abstract}
The purpose of this chapter is to present and discuss the essence and importance of accounting in the concept of sustainable development. Considerations are particularly focused on reporting CSR issues.

The growing importance of the idea of sustainable development and the concept of Corporate Social Responsibility that arose on its basis, gave rise to the need for accounting systems to develop solutions enabling the provision of information on the methods and results of implementing these concepts in entities operating on the market. The interest in accounting with regard to the area of sustainable development has contributed to the development of vocabulary related to measurement, calculation, disclosure, reporting and verification of information on the activities of units for sustainable development.

Reporting on Corporate Social Responsibility (CSR) is still largely voluntary and non-standardised. However, there are various international organisations that develop frameworks and voluntary standards for non-financial reporting, the so-called Social Reporting Standards. The most important EU legislative initiative in the field of disclosure concerning environmental, social and corporate governance information is Directive 2014/95/EU of the European Parliament and Council from 22 October 2014 amending Directive 2013/34/EU as regards disclosure of non-financial and diversity in formation by certain large undertakings and groups.

The combination of financial information (financial statements) with non-financial information relating to the environment, society and corporate governance is included in the integrated report.

In Poland, the requirement to present non-financial information related to CSR was introduced by the Accounting Act. Polish companies should prepare a separate report-"Statement on nonfinancial information". In 2017, the Polish Standard of Non-Financial Information (SIN, 2017) was published to help enterprises fulfil their obligations under the EU Directive.
\end{abstract}

Keywords: CSR reporting standards, integrated report, non-financial reporting, social responsibility accounting, sustainability accounting. 


\subsection{Importance of accounting in the concept of sustainable development}

Accounting is commonly called the "language of business" as it enables communication between preparers and users of accounting information. It is also a tool for describing and constructing the image of the economic reality in which an entity operates. Over the years, accounting, especially financial statements, were based mainly on "hard" numbers, informing about the company's financial situation. In previous years, more and more attention has started to be paid to the importance of transparent sustainability and non-financial reporting, where, among others, environmental issues are especially emphasized.

The orientation of accounting for its needs, with regard to the responsibility of organisational units for the economic, social and environmental results of their operations, began in the 1970s in the United States, when the problem of pollution and environmental protection was being increasingly discussed. From then on, the first social balance sheets began to be recorded and the concept of social accounting was introduced (Szadziewska, 2013, p. 136).

The growing significance regarding the idea of sustainable development and the concept of Corporate Social Responsibility that arose on its basis gave rise to the need for the accounting system to develop solutions enabling the provision of information on the methods and results of implementing these concepts in entities operating on the market (Biadacz, 2017, p. 24).

The result is the emergence of different names related to accounting in combination with sustainable development (SD) and the concept of Corporate Social Responsibility (CSR).

In the literature, the following terms can be found: "social accounting", "sustainability accounting", "social responsibility accounting", "social and environmental accounting" and "accounting for sustainable development".

In Table 1, the most popular definitions of accounting in the concept of sustainable development are presented in accordance with the Web of Science Core Collection.

Table 1. The most popular definitions of accounting in the concept of SD

\begin{tabular}{|l|l|}
\hline \multicolumn{1}{|c|}{ Authors } & \multicolumn{1}{c|}{ Definitions of accounting } \\
\hline G. Lehman, 1999 & $\begin{array}{l}\text { Social and Environmental Accounting-two interlocking social mecha- } \\
\text { nisms which can be used to engage the hegemonic and destructive forces of } \\
\text { capitalist relations of production. Social and environmental accounting is two } \\
\text { interlocking social mechanisms which can be used to engage the hegemonic } \\
\text { and destructive forces of the capitalist relations of production. }\end{array}$ \\
\hline R. Gray, 2002 & $\begin{array}{l}\text { Social Accounting - a generic term for convenience to cover all forms of 'ac- } \\
\text { counts which go beyond the economic', and for all the different labels under } \\
\text { which it appears-social responsibility accounting, social audits, corporate } \\
\text { social reporting, employee and employment reporting, stakeholder dialogue } \\
\text { reporting as well as environmental accounting and reporting. }\end{array}$ \\
\hline
\end{tabular}




\begin{tabular}{|l|l|}
\hline \multicolumn{1}{|c|}{ Authors } & \multicolumn{1}{c|}{ Definitions of accounting } \\
\hline $\begin{array}{l}\text { J. Unerman, J. Bebbington, } \\
\text { \& B. O'Dwyer, 2007 }\end{array}$ & $\begin{array}{l}\text { Accounting for Sustainable Development has provided tools in the man- } \\
\text { agement, planning, control and accountability of the economic aspects of an } \\
\text { organisation, broader techniques of sustainability accounting and account- } \\
\text { ability have the potential to be tools in management, planning, control and } \\
\text { accountability for organisations for their social and environmental impact. }\end{array}$ \\
\hline $\begin{array}{l}\text { R.L. Burritt \& S. Schalteg- } \\
\text { ger, 2010 }\end{array}$ & $\begin{array}{l}\text { Sustainability accounting gives recognition to the importance of manage- } \\
\text { ment decision-making and views corporate sustainability accounting as a set } \\
\text { of tools that provide help to managers dealing with different decisions. }\end{array}$ \\
\hline
\end{tabular}

Source: Own research based on (Lehman, 1999; Gray, 2002; Unerman, Bebbington, \& O’Dwyer, 2007; Burritt \& Schaltegger, 2010).

The interest in accounting with concern to the area of sustainable development has contributed to the development of vocabulary related to measurement, calculation, disclosure, reporting and verification of information about the activities of units for sustainable development.

In Table 2, terms used in the characteristics of accounting are presented, taking the concepts of sustainable development into account.

Table 2. Terms used in accounting for sustainable development

\begin{tabular}{|c|c|}
\hline Categories & Terms \\
\hline $\begin{array}{l}\text { 1. Accounting, taking social } \\
\text { and environmental as- } \\
\text { pects into account }\end{array}$ & $\begin{array}{l}\text { - social responsibility accounting; } \\
\text { - social and environmental accounting; } \\
\text { - social accounting; } \\
\text { - sustainability accounting; } \\
\text { - sustainable accounting; } \\
\text { - accounting for sustainable development; } \\
\text { - accounting for sustainability; } \\
\text { - environmental accounting; } \\
\text { - triple bottom line accounting }\end{array}$ \\
\hline $\begin{array}{l}\text { 2. Reporting on social and } \\
\text { environmental issues }\end{array}$ & $\begin{array}{l}\text { - social reporting; } \\
\text { - environmental reporting; } \\
\text { - social and environmental reporting; } \\
\text { - CSR reporting; } \\
\text { - social responsibility reporting; } \\
\text { - non-financial reporting; } \\
\text { - integrated reporting; } \\
\text { - corporate sustainability reporting; } \\
\text { - triple bottom line reporting; } \\
\text { - environmental social and governance reporting }\end{array}$ \\
\hline $\begin{array}{l}\text { 3. Disclosures on social and } \\
\text { environmental issues }\end{array}$ & $\begin{array}{l}\text { - social and/or environmental disclosures; } \\
\text { - sustainability disclosures; }\end{array}$ \\
\hline $\begin{array}{l}\text { 4. Statement of environmen- } \\
\text { tal and social costs and } \\
\text { benefits }\end{array}$ & $\begin{array}{l}\text { - environmental costing; } \\
\text { - full environmental cost accounting; } \\
\text { - environmental budgeting; } \\
\text { - social cost-benefit analysis }\end{array}$ \\
\hline
\end{tabular}




\begin{tabular}{|l|l|}
\hline \multicolumn{1}{|c|}{ Categories } & \multicolumn{1}{c|}{ Terms } \\
\hline 5. Revision or validation of & - Corporate Social Responsibility audit; \\
environmental and social & - CSR audit; \\
reporting revision or vali- & - Corporate Social Responsibility auditing; \\
dation of environmental & - assurance of Corporate Social Responsibility reports; \\
and social reporting & - external assurance on sustainability reporting; \\
& - sustainability reporting assurance; \\
& - external sustainability assurance on sustainability reporting; \\
& - sustainability reporting assurance; \\
& - sustainability assurance; \\
& - environmental audit; \\
& - sustainability audit; \\
& - non-financial audit \\
\hline
\end{tabular}

Source: (Zyznarska-Dworczak, 2019, p. 66).

In summary, the goal of accounting for sustainable development is to meet the information needs of external and internal stakeholders.

Accounting challenges are:

- providing environmental, social and economic information;

- integrating quantitative and qualitative information;

- reporting the company's impact on environment and society;

- preparation of tools supporting the process of preparing integrated reports.

\subsection{Integrated reporting}

The implementation of the idea of Corporate Social Responsibility is reflected in the development of corporate reporting. In practice, reporting on CSR issues may assume different forms. In recent years, numerous regulations (norms, standards and guidelines) have been developed for the preparation of CSR reports. An attempt to combine financial and non-financial information about the entity's operations was made under a new reporting concept, known as integrated reporting (Remlein, 2019, p. 49). The best known CSR reporting standards are presented in Table 3.

Table 3. CSR reporting standards

\begin{tabular}{|l|l|}
\hline \multicolumn{1}{|c|}{ Organisation } & \multicolumn{1}{c|}{ CSR reporting standards } \\
\hline Global Reporting & GRI Sustainability Reporting Standards \\
Initiative (GRI) & Universal Standards: \\
& - GRI 101 Foundation; \\
& - GRI 102 General Disclosures; \\
& - GRI 103 Management Approach. \\
& Topic-Specific Standards: \\
& - GRI 200 Economic; \\
& - GRI 300 Environmental; \\
& - GRI 400 Social \\
\hline
\end{tabular}




\begin{tabular}{|c|c|}
\hline Organisation & CSR reporting standards \\
\hline $\begin{array}{l}\text { The Organisation for } \\
\text { Economic Co-operation } \\
\text { and Development }\end{array}$ & $\begin{array}{l}\text { OECD Guidelines for Multinational Enterprises } \\
\text { 1. Concepts and Principles; } \\
\text { 2. General Policies; } \\
\text { 3. Disclosure; } \\
\text { 4. Human Rights; } \\
\text { 5. Employment and Industrial Relations; } \\
\text { 6. Environment; } \\
\text { 7. Combating Bribery, Bribe Solicitation and Extortion; } \\
\text { 8. Consumer Interests; } \\
\text { 9. Science and Technology; } \\
\text { 10. Competition; } \\
\text { 11. Taxation }\end{array}$ \\
\hline $\begin{array}{l}\text { The International } \\
\text { Organization for } \\
\text { Standardization (ISO) }\end{array}$ & $\begin{array}{l}\text { ISO 26000, International Standard for social responsibility } \\
\text { 1. Concepts, terms and definitions related to social responsibility; } \\
\text { 2. Background, trends and characteristics of social responsibility; } \\
\text { 3. Principles and practices relating to social responsibility; } \\
\text { 4. Core subjects and issues of social responsibility; } \\
\text { 5. Integrating, implementing and promoting socially responsible behaviour } \\
\text { throughout the organisation and, through its policies and practices, within } \\
\text { its sphere of influence; } \\
\text { 6. Identifying and engaging with stakeholders; } \\
\text { 7. Communicating commitments, performance and other information related } \\
\text { to social responsibility }\end{array}$ \\
\hline
\end{tabular}

Source: Own research based on (GRI, 2020; ISO 26000:2010; OECD Guidelines, 2020).

The most important EU legislative initiative in the field of disclosure of environmental, social and corporate governance information is Directive 2014/95/EU of the European Parliament and Council from 22 October 2014, amending Directive 2013/34/EU, as regards disclosure of non-financial and diversity information by certain large undertakings and groups. The directive requires large European units to disclose information on environmental, social, labour and human rights issues, and counteract corruption as well as bribery. Moreover, these entities must disclose the diversity policy applied to their administrative, management and supervisory bodies. The provisions of the directive have been implemented by all member states and enforced since 1 January 2017.

The combination of financial information (financial statements) with nonfinancial information relating to the environment, society and corporate governance is included in the integrated report. The framework for integrated reporting is released by the International Integrated Reporting Council (IIRC), which is a global coalition of regulators, investors, companies, standard setters, accounting professionals, academia and NGOs (IIRC, 2013, p. 1).

The main purpose of an integrated report is to explain to the provider of financial capital how an organisation creates value over time (Figure 1). An integrated report 
benefits all stakeholders interested in a company's ability to create value, including employees, customers, suppliers, business partners, local communities, legislators, regulators and policymakers, although it is not directly aimed at all stakeholders (IIRC, 2013, p. 7).

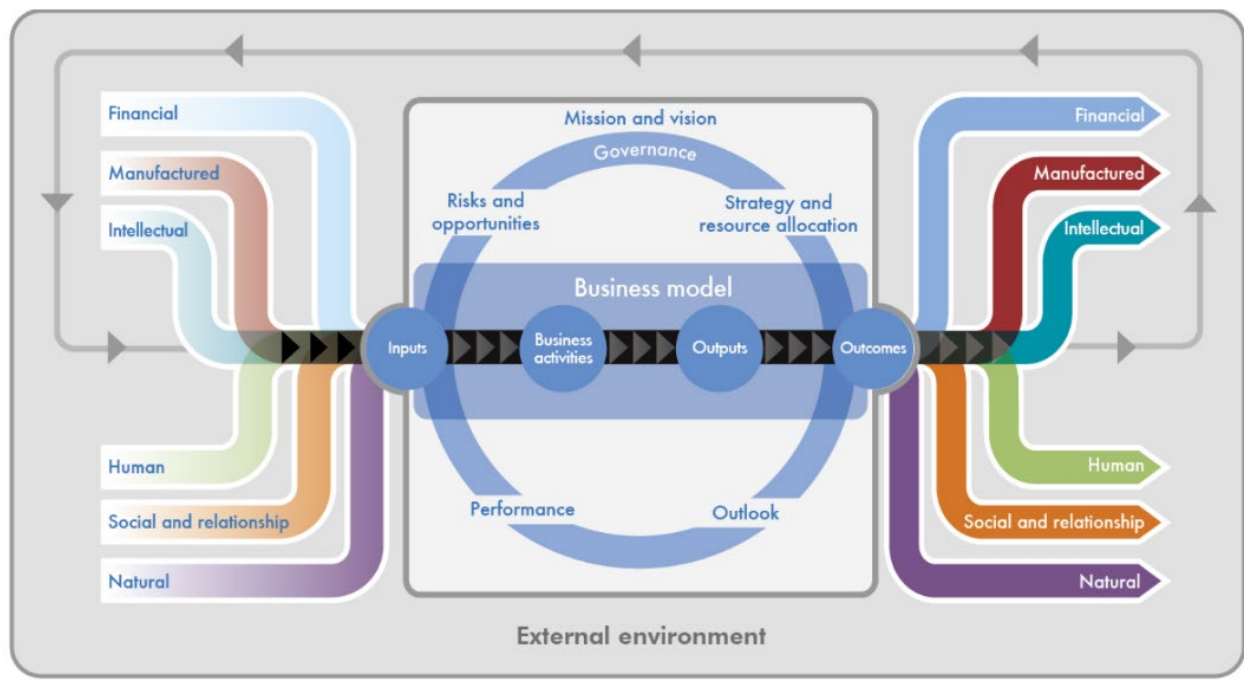

Value creation (preservation, diminution) over time

Figure 1. Value creating process

Source: (IIRC, 2013, p. 13).

Integrated reporting is built around the following content elements (IIRC, 2013, pp. 24-29):

- Organisation overview and external environment in which it operates;

- What does the organisation do and what are the circumstances under which it operates?

- Governance: How does an organisation's governance structure support its ability to create short, medium- and long-term value?

- Business model: What is the organisation's business model?

- Risk and opportunities: What are the specific risks and opportunities that affect the organisation's ability to create short-, medium- and long-term value, and how does the organisation deal with them?

- Strategy and resource allocation: Where does the organisation want to go and how does it intend to get there?

- Performance: To what extent has the organisation achieved its strategic objectives for the period and what are its outcomes in terms of effects on capital? 
- Outlook: What challenges and uncertainties is the organisation likely to encounter in pursuing its strategy, and what are the potential implications for its business model and future performance?

- Basis of preparation and presentation: How does the organisation determine what is important enough to include in the integrated report and how are such matters quantified and evaluated?

A good example of an integrated report might be the 2019 Integrated Annual Report of the Coca-Cola Hellenic Bottling Company. Among Polish companies, the 2019 Integrated Annual Report of LOTOS Group may be of interest.

\subsection{Polish legal regulations on non-financial reporting}

Poland is a member of the European Union, therefore, Polish enterprises are obliged to present non-financial information in accordance with the 2014/95/EU Directive ${ }^{1}$. Moreover, in Poland, the requirement to present non-financial information regarding CSR was introduced by the Accounting Act. In accordance with the provisions of the Act, the so-called public trust entities are required to present activities in a separate part of the report called "Statement on non-financial information" (Act from 15 December 2016, Art. 49b. 1).

The statement should contain at least (Act of 15 December 2016, Art. 49b. 2):

1) a brief description of the entity's business model;

2) key, non-financial performance indicators related to the entity's operations;

3) a description of the policies applied by the unit in relation to social and labour issues, the natural environment, respect for human rights and counteracting corruption, as well as a description of the results of applying these policies;

4) description of due diligence procedures;

5) description of significant risks related to the activities of the entity that may have adverse effects on the issues referred to in point 3 , including risks related to the products of the entity or its relations with the external environment, comprising contractors, as well as a description of risk management.

The information found in the "Statement on non-financial information" is intended to help in assessing the development, performance and condition of the entity, as well as the impact of its activities on the entity's environment. The above assessment will significantly help investors to make decisions regarding socially responsible investing by selecting companies implementing the CSR concept.

${ }^{1}$ Details on the 2014/95/EU Directive are contained in 5.1. 
Non-financial information may be presented in:

- a report on the company's operations as it separate part (statement on nonfinancial information), or

- a separate report, e.g. social, CSR, integrated or impact report.

Decisions on the choice of the non-financial information presentation variant are made by the interested entities. The company may establish its own reporting rules or use any national, EU or international guidelines/standards. The reporting organisation is required to indicate which principles or standards/guidelines have been used in preparing the statement or a create a separate non-financial report.

In 2017, the Polish Standard of Non-Financial Information (SIN, 2017) was published to help enterprises fulfill their obligations under the EU Directive.

SIN is designed to be a simplified form of the Global Guidelines Reporting Initiative. The internal structure of SIN is as follows:

1. Basic part, which includes (SIN, 2017):

- non-financial reporting and its scope;

- national and industry specification;

- significance of indicators and their selection from the point of view of capital markets;

- scope of the standard and descriptions regarding individual reporting areas.

2. Appendix 1: legal interpretations of Directive 2014/95/EU-description of criteria, resulting indevelopment of non-financial information reporting obligation.

3. Appendix 2: significance matrix-matrix connecting areas and indicators defined in the SINstandard regarding their potential significance with division into industries.

4. Appendix 3: interested parties and key responsibility areas-stressing the fundamental significanceof relations between a company and its interested parties.

5. Appendix 5: significance of indicators and its selection from the point of view of capital markets, which-as established-are to make it possible to verify the degree of carrying out the goals and plans of a company.

6. Appendix 6: detailed description of-managerial (G), environmental (E), social and labour (S) areas.

\section{Questions / tasks}

1. Define accounting in the concept of SD.

2. Describe the characteristics of accounting taking the concepts of sustainable development into account.

3. Explain to what the concept of Corporate Social Responsibility (CSR) reporting refers. 
4. List the most commonly used social responsibility reporting standards and the organisations that have developed them.

5. Explain the main purpose of integrated reports.

6. List the primary groups of beneficiaries of integrated reports.

7. Discuss the information the "Statement on non-financial information" should contain.

8. Explain the internal structure of SIN.

\section{References}

Biadacz, R. (2017). Rachunkowość społeczna w świetle badań polskich autorów. Zeszyty Teoretyczne Rachunkowości, 94(150), 23-42.

Burritt, R. L., \& Schaltegger, S. (2010). Sustainability accounting and reporting: fad or trend?. Accounting, Auditing \& Accountability Journal, 23(7), 829-846.

Directive 2014/95/EU of the European Parliament and of the Council of 22 October 2014 amending Directive 2013/34/EU as regards disclosure of non-financial and diversity information by certain large undertakings and groups. Official Journal of the European Union, L 330. Retrieved October 2, 2020 from https://eur-lex.europa.eu/legal-content/EN/TXT/?uri=CELEX\%3A32014L0095

European Commission (2011). Summary report of the responses received to the public consultation on disclosure of non-financial information by companies, directorate general for the internal market and services. Brussels, Belgium.

Gray, R. (2002). The social accounting project and accounting organizations and society privileging engagement, imaginings, new accountings and pragmatism over critique?. Accounting, Organizations and Society, 27(7), 687-708.

GRI-Global Reporting Initiative. (2020). Retrieved October 2, 2020 from https://www.globalreporting.org/standards/the-reporting-process/

Integrated Annual Report 2019 of Coca-Cola Hellenic Bottling Company. Retrieved October 2, 2020 from https://www.coca-colahellenic.com/en/investors-and-financial/2019-integrated-annual-report

Integrated Annual Report 2019 of LOTOS Group. Retrieved October 2, 2020 from https://raportroczny.lotos.pl/

International Integrated Reporting Council [IIRC]. (2013). The International $<$ IR $>$ Framework. Retrieved October, 2020 from https://integratedreporting.org/wp-content/uploads/2015/03/13-12-08-THE-INTERNATIONAL-IR-FRAMEWORK-2-1.pdf

ISO 26000:2010. Guidance on social responsibility. Retrieved from https://www.iso.org/standard/42546. html

Lehman, G. (1999). Disclosing new worlds: a role for social and environmental accounting and auditing. Accounting, Organizations and Society, 24(3), 217-241.

OECD Guidelines for multinational enterprises. Retrieved October 2, 2020 from https://www.oecdguidelines.nl/oecd-guidelines/all-about-the-oecd-general-information

Remlein, M. (2019). Społecznie odpowiedzialne inwestycje w sprawozdawczości przedsiębiorstw. Poznań: Wydawnictwo Uniwersytetu Ekonomicznego w Poznaniu.

SIN. (2017). Standard Informacji Niefinansowych. Warszawa: Fundacja Standardów Raportowania. Retrieved September, 2020 from https://standardy.org.pl/wppsndrd/wp-content/uploads/2017/10/ SIN.pdf 


\section{5.}

Marzena Remlein

Szadziewska, A. (2013). Sprawozdawcze i zarządcze aspekty rachunkowości środowiskowej. Gdańsk: Wydawnictwo Uniwersytetu Gdańskiego.

Underman, J., Bebbington, J., \& O’Dwyer, B. (2007). Introduction to sustainability accounting and accountability. In J. Unerman, J. Bebbington I B. O’Dwyer (Eds.), Sustainability accounting and accountability. Routledge.

Zyznarska-Dworczak, B. (2019). Rachunkowość zrównoważona w ujęciu kognitywno-teoretycznym. Poznań: Wydawnictwo Uniwersytetu Ekonomicznego w Poznaniu. 


\title{
6.
}

\section{SOCIAL RESPONSIBILITY AND OUALITY: ISSUES OF COMPETITIVENESS AND SUSTAINABLE DEVELOPMENT}

\author{
Krisztián Kis \\ Faculty of Engineering, University of Szeged
}

\begin{abstract}
It can be stated that quality is a multifaceted concept, and it makes the difference between any perceivable or conceivable entities visible. The meaning of quality has greatly changed over the years, its content has expanded and quality has become the most important single factor for success. Therefore, it is no exaggeration to say that "quality means business". However, quality, as it will be seen, means much more than that. Corporate Social Responsibility and the service of Sustainable Development Goals have become part of organisational quality. Nonetheless, without innovation, there is no quality or competitiveness, thus, there is no business either.

This is the $21^{\text {st }}$ century, which, according to Joseph M. Juran, will be the century of quality. It is important to note that companies are not just economic units or merely market participants, but also social factors and entities influencing the environment. For this reason, compliance with social norms and ethical expectations is also an important aspect of their operation. To meet the expected and latent needs of customers and users, and also the requirements of society as well as the natural environment in a way that all stakeholders are equally satisfied is a fundamental issue for companies, today and even more so in the future.

The main purpose of this chapter is to discuss how quality should be understood, and what the relationships between the issues involved are. In the chapter, it is argued that quality, Corporate Social Responsibility, innovation, competitiveness and sustainable development are interrelated concepts. Therefore, it is the further purpose of this chapter to discuss how social responsibility and innovation affect quality, and how quality contributes to competitiveness and sustainable development.

In this chapter, quality issues are dealt with from different aspects. In the first part, the concept of quality is presented, which deals with the evolving notion of quality and the future of quality in light of social responsibility. In the second part, complexity issues and emergences are introduced, while quality is discussed as an emergent property, and the role played by social responsibility and environmental concerns in competitiveness and sustainable development are explained, and furthermore, innovation from quality and responsibility perspectives are examined.
\end{abstract}

Keywords: competitiveness, Corporate Social Responsibility, innovation, quality, sustainable development. 


\subsection{Understanding quality and its relation to social responsibility and sustainable development}

\section{The concept and meaning of quality}

As already mentioned, quality has become an essential factor for the competitiveness of enterprises. Companies should keep up with customers' expectations, as their needs continue to grow and evolve, thus, they require products and services that are better, brighter, faster, cheaper, and so on. In addition, other stakeholders as well as their needs and interests have emerged and require being recognised and fulfilled. Therefore, quality and its management have become a central issue in the operation of companies, and as a result of which, the performance of the organisations, the quality of their processes, products and services can be continuously and significantly improved. At the same time, it is important to emphasize that companies need to integrate into the social division of labour, while they are meeting the growing needs of customers and other stakeholders in a more competitive way than other businesses.

Quality is a well-known and frequently used term, however, it can be stated that it is interpreted by many, in various ways, hence, there are several interpretations of the concept of quality. Answering the question of "What is quality?", is not an easy task. Quality is a multifaceted concept that can be approached from multiple directions. For example, if we look at what is written about quality in dictionaries, we find the following: "the standard of something when it is compared to other things like it", "how good or bad something is" (oxfordlearnersdictionaries.com), "a characteristic or feature of someone or something" (dictionary.cambridge.org). According to the traditional interpretation of quality, products and services must meet the needs of their users. Similar definitions are, for example: "fitness for use" or "conformance to requirements".

The difficulties and slipperiness of defining quality are well-illustrated by the 5 approaches to defining quality described by Garvin (1984), which represent different interpretations of the concept of quality: 1) transcendent, 2) product-based, 3) user-based, 4) manufacturing-based and 5) value-based. Each approach represents an aspect of quality with various meaning of the concept of quality. According to Fields, Hague, Koby, Lommel, and Melby (2014), each aspect provides only a limited view of quality, thus, in order to obtain a comprehensive view of quality, one must employ all approaches.

There is an increasingly widespread and broadly implemented definition of quality, defined by the ISO 9000:2015 standard as follows: the "degree to which a set of inherent characteristics of an object fulfils requirements" (ISO, 2015a). According to Antilla and Jussila (2017), this definition refers to the needs and expectations of all parties concerned, and with this definition in mind, we can consider the quality 
of an organisation as a whole, on the one hand, and the quality of the entities being exchanged between the organisation and its stakeholders on the other.

Another example of the definition of quality is given by Narayanan Ramanathan, who argues that the concept of quality needs to be reinterpreted within the context of the environmental and social problems, as well as challenges facing the globalised world. Based on the Brundtland Commission's definition of sustainable development, Ramanathan (2015) proposed the following definition of quality: "Fulfill stated, implied and latent needs of customers in a manner that preserves the earth not only for future generations of humans but for all living things".

We may conclude that there is no single or everlasting definition of quality accepted by all. But regardless of which definition we accept, and irrespective of the context in which it is used, as Dale (2003) points out, it usually distinguishes one organization, event, product, service, process, person, result, activity, or communication from another.

\section{The evolving notion of quality}

The concept of quality has broadened and it needs to be reinterpreted accordingly. Initially, quality was primarily related to the product, the quality of the product was at the centre, but in the course of social and economic development, the concept of quality expanded to include all aspects of organisational operation, therefore, quality became a system-level concept.

Through the processes and changes taking place in the world, the concept of quality is also changing. For that reason, the meaning of quality necessarily changes over time. Shiba et al. (1993) distinguished 4 phases or levels of development in the evolution of quality. Briefly, they are as follows:

1) "fitness to standard", i.e., conformance to the specifications;

2) "fitness to use", i.e., meeting known customer needs, satisfying the customers' requirements;

3) "fitness of cost", that means achieving customers' requirements at low cost, otherwise maintaining high-quality or increasing quality while reducing costs;

4) "fitness to latent requirement" (delighting the customer), that is compliance with the latent needs of customers, which means anticipating customers' needs, even before they are aware of them.

Almost 30 years ago, in connection with the further development and expansion of the concept of quality, with great foresight, Shoji Shiba, Alan Graham, and David Walden gave some hints on the possible direction regarding the evolution of quality. In accordance with the rapidly changing world, they found it very likely that the concept of quality will continue to evolve and expand. The authors mentioned 2 dimensions or levels of quality that are now becoming more widespread 
and obvious, such as: 5) "fitness to corporate culture" and 6) "fitness to societal and global environment" (Shiba, Graham, \& Walden, 1993).

These "fitnesses" (or "conformances") can be considered as the $5^{\text {th }}$ and $6^{\text {th }}$ levels of quality evolution. According to this, companies are increasingly making decisions about their operation and promoting themselves based on their corporate (organisational) culture. While there is also an increasing pressure on companies to improve the working environment of their employees and the environmental compliance of their products as well as manufacturing processes. This leads to an interpretation of quality that incorporates the needs of the natural and broader social environment in which the customers exist and live. Thus, according to today's interpretation of quality, environmental considerations and social responsibilities are part of the concept of quality. In this regard, commitment to environmental and social sustainability or to the environmental and social aspects of sustainable development are critical success factors for businesses.

Quality-oriented companies must be aware of, and address all fitnesses. This is because companies must take the different levels of quality into account, and in order to maintain and improve their competitiveness, the different fitnesses need to be integrated into their operations, which gives them the opportunity to distinguish themselves from others and gain competitive advantage over their rivals. The evolution of the concept of quality is, in fact, a continuous response and adaptation to the growing expectations of the society. In order to improve their competitiveness, companies must consider all the fitnesses that they should implement in parallel with regard to their operation. Companies that operate at a higher level in terms of various fitnesses, are able to adapt successfully (Shiba et al., 1993).

Similarly to the above, the change in the interpretation of quality is also represented by the concept of so-called "little q" and "big Q". The "little q" describes quality in a narrower sense, it basically focuses on product quality, and it sees quality as a technological or production problem. In contrast, "big Q" interprets quality in a broader sense, with a management focus, seeing quality in a more comprehensive and systematic way. According to West and Cianfrani (2018), "big Q" can be defined "as strategically managing quality in all business processes, products and services as they relate to all relevant interested parties". It is important to emphasize that these 2 approaches to quality are not mutually exclusive, but rather complementary to each other. The "big Q" concept includes the "little q" that focuses on product quality, and also includes organisational culture and also the consideration of stakeholders' expectations. As Cianfrani, Sheps, and West (2019) point out, the "big Q" represents a culture that addresses not only the product quality, but also that organisational. The goal is to achieve customer and other stakeholder satisfaction. If an organisation wants to remain competitive, it must meet the needs and expectations of all stakeholders. Within the context of changes taking place around the world, Saco (2008) introduced another approach 
to the interpretation of quality, which he called the "really big Q". In Saco's view, the discourse on quality should be extended beyond product quality and quality management to issues related to sustainability and responsibility. This needs to be done so at a higher level, not just at the level of organisations or firms. This brings us to quality at the level of entire social system, where issues such as global warming, business ethics, ecosystem services, sustainable development or reciprocity, are addressed. The 3 approaches to the concept of quality ("little q", "big Q" and "really big Q") are complementary and reinforce each other, and thus, ensure the value that organisations can provide to stakeholders. In the course of the evolution of quality, the concept of quality has changed radically from the quality of products and services, through the quality of management, to the quality of life. It can be seen that the concept of quality has broadened in scope as it has evolved over time.

\section{The future of quality}

In the study published by the American Society for Quality (ASQ) in 2011, 8 factors were identified that will have significant influence on the future of quality in coming years. The identified forces of change that will shape the future of quality are as follows: 1) global responsibility, 2) consumer awareness, 3) globalisation, 4) the increasing rate of change, 5) the workforce of the future, 6) aging population, 7) $21^{\text {st }}$-century quality, and 8 ) innovation.

Global responsibility represents an increased awareness of social responsibility and global implications of local decisions. Global responsibility means an ethical mindset and behaviour at all levels of society (e.g., governments, corporations, NGOs, families and individuals) in which stakeholders increasingly understand the meaning of responsibility and are committed to enforcing it.

In the ASQ (2011) study, it is highlighted that in previous ASQ research on the future of quality, "environmental sustainability" was added to the list of key factors shaping the future of quality in 1999, while "environmental concerns" and "social responsibility" were included as key factors in 2008. These issues were raised to a higher level by introducing the concept of so-called "global responsibility" in the 2011 study. All this relates to the growing understanding of the relationship between individual and organisational decision-making and the sustainability of this planet. As a result, stakeholders have become increasingly aware of organisations' negative impact, and the commitment to social and environmental responsibility has become an imperative for organisations. Within this context, it is concluded that this has become essential for organisations to examine the potential consequences of their decisions on consumers, customers, employees, communities and the environment, as stakeholders' expectations go far beyond the quality of products and services, 
with increasing attention paid to social and environmental influence created and generated by the organisations (ASQ, 2011).

The former is supported by the 2009 report of the Conference Board Quality Council. In the research report on the future of quality, it is noted that quality remains a key factor in maintaining the competitiveness of companies, while several trends and circumstances are forcing companies to redefine and communicate their values in order to keep pace with market needs. In the report, it is pointed out that today, a perfect product or service is no longer enough, which is actually a supposed requirement for success in the market. Quality is thought to be embedded in corporate processes and is taken for granted in several cases. At the same time, the environment in which quality must be achieved has changed dramatically. The world is transforming at an accelerating pace, and economic, social and environmental processes and contexts require greater understanding. In connection with these, the Conference Board Quality Council identified 4 primary trends that affect quality today and in the future. These trends are: 1) globalisation, 2) customer sophistication, 3) talent management and leadership issues, and 4) environmental concerns and social responsibility. These trends reflect the 8 forces of change that are shaping the future of quality as reported in the 2011 ASQ study.

The new dimension of quality requires professionals to go beyond previous approaches and practices. In order to adapt to the challenges posed by trends that affect organisational strategies and business results, they need to further develop their operations, especially in the field of strategic thinking. The report allows to emphasize the following with regard to environmental concerns and social responsibility. Environmental concerns are part of a larger trend toward Corporate Social Responsibility. In this context, the concept of "doing well by doing good" is becoming imperative for all organisations to incorporate in their business operations. It is highlighted that it is not just good citizenship but also, Corporate Social Responsibility drives bottom-line results which embrace growth and profit. Consumers are more and more frequently requiring companies to take reasonable steps to save our planet if they are to buy their products and services. In this respect, responsible corporate practices and behaviour greatly affect purchasing decisions (Gutner \& Adams, 2009).

Regarding the evolution of quality, it can be said that quality has come a long way, from being an aspect of product to the quality of the enterprise itself. In connection with the future of quality, the 2011 ASQ study states that "whatever quality is today, it would surely evolve in response to the constellation of forces it joins in shaping the future" (ASQ, 2011).

In an essay, the Japanese quality guru Noriaki Kano emphasizes the importance of understanding the needs and expectations of stakeholders, while highlights the need for offering products or services that take into account not only the customer 
but also the environment. In terms of quality, products and services are needed that consider the interactions between the organisation and its environment, given the expectations of consumers and the environment, in order to achieve development that does not leave a negative legacy for future generations (Kano, 2005).

The above are exemplified by the quality policy of Hungary's largest agricultural and food company (Table 1), which summarizes the stated intentions and directions of the company's top management related to quality and serves as a basis for defining the company's quality objectives. The main message of the quality policy is that the company declares its social responsibility and commitment to meet the needs and requirements of stakeholders. Acting and behaving in accordance with the intentions and directions included in the quality policy can contribute to an increase the competitiveness of the firm and to the promotion of sustainable development.

\section{Table 1. Quality policy of the Bonafarm Group}

Bonafarm Group as the largest food and agricultural group in the country, is committed to fulfilling the needs of its customers, consumers and other business partners at the highest level.

From farm to fork, we provide advanced technology and innovation for the food production, in order to be sure that only safe and excellent quality products are delivered to our customers and consumers.

Our operation complies with all the relevant national and international regulations, which are the fundamental guiders of our activities.

In our conviction, the respect of traditions, social responsibility and the protection of the environment are equally important.

Through our operation, we provide the conditions for sustainable development, we take responsibility for the environment and all values, resources that we use or hand on further.

The expectations for corporate and personal behaviour are incorporated in the Group's Code of Ethics.

We provide all our employees across the value chain with up-to-date knowledge, to achieve our goals through regular teaching and development.

The top management of the Bonafarm Group and its strategic partners is committed to developing and maintaining quality management, food safety and an environmental management system. We will carry out the requirements of the systems by setting an example and fully engaging every employee at all levels of the organisation.

Our quality policy applies to all Bonafarm Group and its strategic partner members and locations.

Source: (https://mcs.hu/wp-content/uploads/2018/02/qp.gif).

In conclusion, it may be stated that the evolution of quality actually represents the path towards sustainable development, but it could also be said that the essence of the path to sustainable development is expressed by the evolution of quality. 


\subsection{Creating quality through innovation to promote competitiveness and sustainable development}

\section{Complexity and emergence}

In the previous section, we could see that social responsibility is becoming an increasingly important aspect in the adaptation process of businesses.

If we accept the proposition that the evolution of quality represents the path to sustainable development, then we can say that social responsibility is one aspect of this evolutionary process in which companies are making efforts to provide added value to a wider range of stakeholders while taking the integrity of the environment and the whole ecosystem into account. Assuming that development means an increase in complexity, it becomes apparent that the relationships between entities are more and more appreciated. The point is that the properties of the whole cannot be deduced from its parts alone, because something new is created through interactions between them.

Due to the interactions between the parts of the system, the behaviour of the parts changes, and as a result of which, the whole system behaves differently than without interactions (Náray-Szabó, 2006). All this makes us think about the interactions between the components, the interrelation of the whole and its parts, the relationships between parts and the whole, the complexity, and the creation of new quality. Understanding and managing complexity requires a systemic approach.

It is greatly probable that everyone has heard the saying - "the whole is greater than the sum of its parts", which mathematically, is untrue. However, the situation is quite different in the case of social systems. According to La Porte's (1975) definition, the degree of complexity with regard to organised social systems is determined by the number of system components, their variety or differentiation, as well as the degree of interdependence among these components. Thus, the greater the number and differentiation of the components and the degree of their interdependence, the greater the complexity. In complex systems, as a result of the interactions between parts, the behaviour of the parts changes in such a way that the whole system follows a qualitatively new pattern of behaviour that differs from the properties of the parts (Vicsek, 2003). This behaviour of a system is called emergence, which occurs (emerges) when the component parts interact as a whole. The appearance of this behaviour in a system is the result of the interactions between the component parts.

Each system is characterised by internal relations among its parts and by the external relations with other systems. The development, as noted above, is realised through relations and interactions. From these relations, new and, in some cases, very special and unexpected features and qualities originate. These properties cannot be attributed to any or the sum of the relating parts. They are called "emergent 
properties" (Conti, 2009). We are surrounded by many emergent properties, just think of life, consciousness, friendship or love. What these properties, behaviours or qualities have in common is that they emerge only when the parts interact in a wider whole. Thus, the entity (a system) has such properties its parts do not have on their own. Then, the claim that "the whole is greater than the sum of its parts" becomes true.

\section{Quality as an emergent property}

Organisational excellence is also an emergent property. As such, it originates from relations more than from individual attributes or from the technology used. If that is true, leaders who strive for excellence should consider it their first and most important responsibility to create, promote and encourage the creation of relations capable of generating outstanding value (Conti, 2009). In this way, the relations and interactions with stakeholders, the emergence of a stakeholder network, the nature and dynamics of the relationship between a company and its stakeholders, are extremely important factors in the value creation process. Therefore, the role of systems approach in managing for quality is evident.

The above allows to draw attention to the fact that the individual entities and actors are not independent of each other, they are part of a wider whole as they interact with each other and can all have impact on development. As stated in the ISO 9000:2015 standard-“An organization focused on quality promotes a culture that results in the behavior, attitudes, activities and processes that deliver value through fulfilling the needs and expectations of customers and other relevant interested parties." In the standard, the "ability to satisfy customers and the intended and unintended impact on relevant interested parties" is emphasized, being decisive factors in the quality of an organisation's products and services. The standard also allows to highlight that the concept of interested parties or stakeholders goes beyond focus merely on the customer, stakeholder identification being part of the process for understanding the organisation's context. It is of paramount importance for organisations to gain and retain the support of stakeholders, on whom the success of the organisation depends (ISO, 2015a).

The relationship of companies with the natural environment has long been rather one-sided: companies have exploited natural resources, and in many cases, they become the cause of negative environmental impact. In recent decades, however, significant changes have taken place in this domain, which can be traced back to the recognition of limitations in natural resources and the strengthening of social responsibility. According to the concept of responsible company, a business has a social responsibility and it rationally decides on morally acceptable alternatives (Chikán, 2000). 
According to this view, it is significant to consider all relevant stakeholders and their interests must be taken into account in decision-making. This is the so-called stakeholder approach, which assumes that companies are not isolated entities or systems, but are embedded in a social context, and therefore, they can only achieve their goals if they meet stakeholders' requirements and expectations. Who are the stakeholders? - we may ask. In this regard, the stakeholder is an entity that can influence the operation of the company and/or has a specific interest in the outcomes of that company. In other words, as defined by the standard, an entity "that can affect, be affected by, or perceive itself to be affected by a decision or activity" (ISO, 2015a).

The range of stakeholders can be quite broad and varied, and they can be grouped on the basis of several aspects (see, for example, internal and external, or actual and potential stakeholders). In a traditional sense, stakeholders include individuals or organisations, such as customers, owners, shareholders, and competitors. However, this is limited to a narrow circle of stakeholders. Entities, in a broader sense, can refer to individual citizens, organisations, businesses, groups of people, systems, ecosystems, or even members of future generations. From a broader perspective, it can be seen that stakeholders also include entities that are unable to represent their interests during deliberations on impact. These entities are called quiet or silent stakeholders. Such a quiet or silent stakeholder could be, for example, a vulnerable environment, an ecosystem or species, and even members of future generations who are clearly unable to represent their "interests" in human decision-making processes. According to Schienke (2020), to ensure that the outcome and impact of actions do not adversely affect stakeholders, a comprehensive stakeholder analysis is required, which includes representations of entities that cannot represent themselves.

This approach connects the company with the stakeholders, which can give companies a competitive advantage as long as they contribute to meeting the expectations of the stakeholders, thus ensuring long-term successful operation. Social responsibility is, therefore, an important aspect of maintaining corporate competitiveness, which requires companies to be able to continuously manage their internal and external relations, perceive changes and adapt to them in a responsible and timely manner.

\section{Responsibility, competitiveness and sustainability}

Chikán (2008) defines firm competitiveness as "a capability of a firm to sustainably fulfill its double purpose that is meeting customer requirements at profit". This capability is realised through offering goods and services on the market which customers value more higherly than those offered by competitors, while complying with social responsibility requirements. In its Green Paper titled Promoting a European framework for Corporate Social Responsibility, the European Commission (2001) also 
highlighted the positive link between socially- and environmentally-responsible corporate behaviour and competitiveness. All this is confirmed by several commentators in the literature. According to Nagy (2014), CSR is definitely good for business, as it generates a competitive advantage by incorporating non-economic factors into the activities of a company, thereby building image and respect, and changing attitudes and behaviour towards a positive direction among customers and employees. Furthermore, it can result in a win-win situation between the company and the community. Chikán (2000) adds that in communities with a developed social consciousness, pursuing moral goals can have a beneficial effect on profitability as ethical behavior is recognised by the community in market competition. Falck and Heblich (2007) argue that by strategically practicing Corporate Social Responsibility, a company can "do well by doing good". In this regard, that means it can earn a profit while, at the same time, making the world a better place. It is a way for both companies and society to benefit and prosper.

Recognising the importance of Corporate Social Responsibility, the International Organization for Standardization (ISO) issued an international standard on social responsibility (ISO 26000:2010) in 2010, entitled Guidance on social responsibility. The standard aims at providing guidance to organisations striving for excellence to put CSR into practice. Accordingly, the ISO 26000 standard provides guidance rather than requirements, thus, it cannot be certified alike other ISO standards. Instead, it helps clarify what social responsibility is, and provides direction and recommendations on how any organisation can improve its social responsibility and thus, contribute to sustainable development.

In Kapussy's (2010) view, a fundamental attribute of CSR, i.e. socially responsible operation, is commitment to sustainable development. In other words, one of the most important responsibilities of a company is to accept the principles of sustainable development and organise its operations accordingly. In this regard, Simonyi and Zsótér (2020) propose an approach, the defining element of which is a longer-term outlook, meaning taking future generations into account. As it is stated in the ISO 26000 standard, "Sustainable development can be treated as a way of expressing the broader expectations of society as a whole" (ISO, 2010). According to Molnár and Balogh (2011), meeting social expectations is one of the most significant values of Corporate Social Responsibility. Castka and Balzarova (2008) argue that the role of ISO 26000 is to facilitate a shift from customer focus to stakeholder focus, hence, creating a business-to-society orientation in organisations.

This shift from a restricted scope focusing only on the customer's needs and expectations to fulfil the needs and expectations of all stakeholders leads to what is called quality of an organisation. This way CSR, Corporate Social Responsibility increases stakeholder satisfaction amid rising expectations, and it becomes a determinant factor of organisational quality, thus, contributing to distinguish companies from one another, and to promote competitiveness and sustainable development. 


\section{Responsibility and innovation}

According to the ISO 9001 standard, adaptation of a quality management system in an organisation "can help to improve its overall performance and provide a sound basis for sustainable development initiatives" (ISO, 2015b). One of the 7 quality management principles described in the ISO 9000 standard is: improvement. Successful organisations place constant focus on improvement, which is crucial for an organisation to enhance its performance level, to respond to changes in its internal and external circumstances, and to create new opportunities. Quality improvement, as part of quality management, is a set of activities focused on increasing the ability to fulfill quality requirements (ISO, 2015a).

According to Anttila and Jussila (2017), quality improvement is achieved through learning and innovation. Organisational learning and innovation promote the organisation's quality improvement activities and quality management system by enhancing the ability to anticipate and respond to the internal and external risks and opportunities in a way that enables it to fulfill its quality objectives (Anttila and Jussila, 2020), in other words, in a way that enables the organisation to create and deliver value for stakeholders. As stated by Anttila and Jussila (2020), in fact, "all innovations aim at quality improvement". Within this context, it is argued in the ASQ (2011) that innovation and quality do not compete with each other, but in fact, complement one another very well. This is also supported by the opinion of Anttila and Jussila (2016), who argue that quality and innovation can be considered as partnering disciplines, "which can be useful to each other and together create organizational differentiation for competitive advantage".

Innovation, as an essential tool for adaptation, contributes to the creation of greater social and economic values provided by organisations. It is important to emphasize that learning, innovation, adaptation, improvement and development are closely interlinked. Innovation requires knowledge, which presupposes learning, so as the continuous and coordinated development of various knowledge and capacities, while adaptation is provided by innovations, which enable organisations to perform at a higher level of quality, and to create social and economic values, as well as benefits.

The previously mentioned researchers' opinions are in line with the Oslo Manual, in which it is stated that the "key components of the concept of innovation include the role of knowledge as a basis for innovation, novelty and utility, and value creation or preservation as the presumed goal of innovation" (OECD/Eurostat, 2018). According to the recently published ISO 56000, Innovation management-Fundamentals and vocabulary, an innovation occurs when a new or changed entity realises or redistributes value (ISO, 2020). Thus, innovation is about creating something new or an improved entity (e.g. product, services, process, model, organisation), that adds value through satisfying the needs and expectations of stakeholders. The 
values that are added can be financial or non-financial, such as social or environmental benefits. Innovations can therefore create values for the stakeholders but, at the same time, they can generate negative effects and potentially undesirable impact on the environment and society. The implications of innovations, such us new or improved products, services or processes for society and the environment, are often difficult to anticipate. Dealing with these potential implications derived from innovations in a responsible manner, is key to bringing innovations to the market. This leads us to the concept of responsible innovation, which is about anticipating and evaluating ethical dilemmas and effects of unforeseen risks related to innovation.

Responsible innovation can be understood as an extension or expansion of Corporate Social Responsibility to the field of innovation processes and outcomes (COMPASS, 2020). The term "responsible innovation" is not included in the Oslo Manual or ISO 56000, but both emphasize the significance of understanding the complex set of factors influencing innovation and the way it affects our societies, anticipating and addressing their unintended consequences.

According to Von Schomberg's (2013) often quoted definition, responsible innovation (or as it is often mentioned: Responsible Research and Innovation, RRI): "is a transparent, interactive process by which societal actors and innovators become mutually responsive to each other with a view to the (ethical) acceptability, sustainability and societal desirability of the innovation process and its marketable products". This means, in order to fulfill the criteria of responsible innovation, both the innovation process and its outcome should meet the requirements of ethical acceptability, sustainability and societal desirability. A shorter but, at the same time, broader definition of responsible innovation is given by Stilgoe, Owen, and Macnaghten (2013). In their interpretation-"Responsible innovation means taking care of the future through collective stewardship of science and innovation in the present". The British Standards Institution defines responsible innovation as "careful consideration of, and action to address, the potential impacts of introducing a new product, service, process or business model" (BSI, 2020). According to these definitions, companies innovating in a responsible manner strive for improving our common future by taking responsibility for, and constantly improving their current innovation practices.

\section{Questions / tasks}

1. How would you define quality?

2. What does quality mean to you?

3. What is the relationship between quality and social responsibility?

4. How does quality relate to sustainability? 
5. Do you agree with the statement that quality plays a key role in ensuring competitiveness? Explain and justify your answer.

6. By what criteria do you judge the quality of a product, a service or an organisation?

7. Choose products with the same function from 2 or more companies and compare them in terms of various finesses. Make conclusions.

8. How do you interpret "little q", "big Q" and "really big Q"? Give examples of these concepts.

9. What do you think are the most important factors influencing the future of quality? Explain and justify your answer.

10. Select a company of your choice and present its actual and possible social and environmental impact created and generated by the organisation.

11. Select an economic sector, company or product, and describe the components of quality in terms of requirements for success on the market.

12. What does the concept of "doing well by doing good" mean to you? What are your expectations in this specific case?

13. How does quality relate to value?

14. What does value mean to you?

15. Select a set of companies and compare their quality policy in light of social responsibility and environmental concerns. Examine how they perform in reality with regard to the above.

16. Select a company of your choice, then examine and present how successful it is in satisfying its stakeholders. Explain and justify your answer.

17. Give examples of how socially and environmentally responsible corporate behaviour can foster competitiveness.

18. In your view, what is the role of the company, the customer, and other stakeholders in value creation? How is the value generated?

19. What is the role of innovation in quality improvement? Give examples of successful innovations that improved quality in terms of social responsibility.

\section{References}

Anttila, J., \& Jussila, K. (2016). Quality and innovation-Partnering disciplines. Proceeding of 17th International Symposium on Quality. Quality makes a difference. Croatian Quality Managers Society, Zadar, pp. 13-35. Retrieved September 25, 2020 from https://www.researchgate.net/ publication/299594879_QUALITY_AND_INNOVATION_-_PARTNERING_DISCIPLINES

Anttila, J., \& Jussila, K. (2017). Understanding quality-conceptualization of the fundamental concepts of quality. International Journal of Quality and Service Sciences, 9(3-4), 251-268. https://doi. org/10.1108/IJQSS-03-2017-0020

Anttila, J., \& Jussila, K. (2020). ISO 9004-A stimulating quality management standard for the creative leaders of contemporary organizations. 21st International Symposium on Quality. Quality-yester- 
day, today, tomorrow. Crikvenica, March 18-20. Retrieved October 21, 2020 from http://hdmk. hr/papers_2020/hdmk_2020_06.pdf

ASQ (2011). Emergence: 2011 future of quality study. American Society for Quality (ASQ). Milwaukee. BSI (2020). PAS 440:2020 Responsible innovation-guide. The British Standards Institution (BSI).

Castka, P., \& Balzarova, M. A. (2008). Adoption of social responsibility through the expansion of existing management systems. Industrial Management \& Data Systems, 108(3), 297-309. https:// doi.org/10.1108/02635570810858732

Chikán, A. (2000). Vállalatgazdaságtan. Aula Kiadó. Budapest.

Chikán, A. (2008). National and firm competitiveness: a general research model. Competitiveness Review, 18(1-2), 20-28. https://doi.org/10.1108/10595420810874583

Cianfrani, C. A., Sheps, I., \& West, J. E. (2019). One small step. How to achieve sustained success through consistent quality. Quality Progress, 54-57.

COMPASS (2020). What is responsible innovation. Retrieved October 24, 2020 from https://innovation-compass.eu/training/3144-2/

Conti, T. (2009). Systems thinking: The new frontier in quality management. Proceedings of the $53^{\text {rd }}$ EOQ Conference, 12-14 May, Dubrovnik, pp. 159-171.

Dale, B. G. (2003). Tools and techniques: An overview (Chapter 16). In B. G. Dale (Ed.), Managing quality (pp. 308-348). 4th ${ }^{\text {ed }}$. Oxford: Blackwell Publishing.

European Commission (2001). Promoting a European framework for Corporate Social Responsibility, Green Paper. Brussels, 18.7.2001. COM(2001) 366 final. Retrieved September 18, 2020 from https://www.europarl.europa.eu/meetdocs/committees/deve/20020122/com(2001)366_en.pdf

Falck, O., \& Heblich, S. (2007). Corporate Social Responsibility: Doing well by doing good. Business Horizons, 50(3), 247-254. https://doi.org/10.1016/j.bushor.2006.12.002

Fields, P., Hague, D., Koby, G. S., Lommel, A., \& Melby, A. (2014). What is quality? A management discipline and the translation industry get acquainted. Revista Tradumàtica: tecnologies de la traducc., 12, 404-412. https://doi.org/10.5565/rev/tradumatica.75

Garvin, D. A. (1984). What does "product quality” really mean? Sloan Management Review, 26(1), 25-43.

Gutner, T., \& Adams, M. (2009): A leadership prescription for the future of quality. Research report. The Conference Board Quality Council. Retrieved October 10, 2020 from https://www.nist.gov/ system/files/documents/2017/05/09/Leadership_Prescription_The_Conference_Board.pdf

ISO (2010). ISO 26000:2010. Guidance on social responsibility. Geneva.

ISO (2015a). ISO 9000:2015. Quality management systems-Fundamentals and vocabulary. Geneva. ISO (2015b). ISO 9001:2015. Quality management systems-Requirements. ISO, Geneva.

ISO (2020). ISO 56000:2020. Innovation management-Fundamentals and vocabulary. Retrieved October 24, 2020 from https://www.iso.org/obp/ui/\#iso:std:iso:56000:ed-1:v1:en

Kano, N. (2005). A minőség evolúciója-a fenntartható növekedés felé vezető út. Minőség és Megbizhatóság, 41(1), 32-42. (The original title of the work: Quality evolution-Way to sustainable growth. Presented at the International Conference on Quality (ICQ) '05-Tokyo; September 13-16, 2005, Tokyo. Translated by: Várkonyi, G.).

Kapusy, P. (2010). Néhány gondolat a vállalatok fenntartható fejlődéséről. Minőség és Megbizhatóság, $4(1), 7-11$.

La Porte, T. R. (1975). Organized social complexity: Challenge to politics and policy. Princetown University Press.

Molnár, P., \& Balogh, A. (2011). A vállalatok társadalmi felelőssége (I. rész). Minőség és Megbizhatóság, 45(4), 210-218.

Nagy, S. (2014). Stratégiai esettanulmányok. In L. Gulyás (Ed.), Stratégiai menedzsment Szun-Ce-tól a kék óceánig (pp. 137-188). JATEPress Kiadó, Szeged. 
Náray-Szabó, G. (2006). Fenntartható a fejlődés?. Budapest: Akadémiai Kiadó.

OECD/Eurostat (2018). Oslo Manual 2018: Guidelines for collecting, reporting and using data on innovation, 4th ed. The Measurement of Scientific, Technological and Innovation Activities. Luxembourg: OECD Publishing, Paris/Eurostat. https://doi.org/10.1787/9789264304604-en

Ramanathan, N. (2015). Quality and the seven environmental challenges of the planet. International Academy for Quality. World Quality Forum. Budapest, October 26-27. Retrieved October 9, 2020 from https://www.eoq.hu/iaq/wqf/papers/a6-2-ramanathan.pdf

Saco, R. M. (2008). From the President: Quality and the three conversations. Quality Progress, July 2008, 8-9.

Schienke, E. W. (2020): Consideration of stakeholders (2.3). In Ethical dimensions of renewable energy and sustainability systems. Retrieved October 14, 2020 from https://www.e-education.psu.edu/ bioet533/node/674

Shiba, S., Graham, A., \& Walden, D. (1993). A new American TQM: Four practical revolutions in management. Center for Quality Management, Cambridge, Massachusetts. Portland: Productivity Press.

Simonyi, P., \& Zsótér, B. (2020). A fenntartható fejlődés, a fenntarthatóság értelmezési kérdései a megvalósítás érdekében. Jelenkori társadalmi és gazdasági folyamatok, 15(1-2), 55-67. https:// doi.org/10.14232/jtgf.2020.1-2.55-67

Stilgoe, J., Owen, R., \& Macnaghten, P. (2013). Developing a framework for responsible innovation. Research Policy, 42(2013), 1568-1580. https://doi.org/10.1016/j.respol.2013.05.008

Vicsek, T. (2003): Komplexitás-elmélet. Magyar Tudomány, 164(3), 305-307.

Von Schomberg, R. (2013). A vision of responsible research and innovation. In R. Owen, J. Bessant, \& M. Heintz (Eds.), Responsible innovation: Managing the responsible emergence of science and innovation in society (pp. 51-74). London: John Wiley. https://doi.org/10.1002/9781118551424.ch3

West, J. E., \& Cianfrani, C. A. (2018). Big Q vs. little q. Quality Progress, September 2018, 50-52. 


\title{
7.
}

SUSTAINABLE DEVELOPMENT IN PRODUCTION-OPERATIONS MANAGEMENT

\author{
Dariusz Nowak \\ Poznań University of Economics and Business
}

\begin{abstract}
Production-operation activity is one of the most important functions of modern enterprises. It requires the involvement of various types of resources, such as: raw materials, materials, machines, capital, information, energy, human factor and others, which are used in production processes. However, many problems arise in operational activity. They concern such aspects as: waste of resources or their wasteful use, mismanagement, excessive energy consumption, environmental pollution, exploitation of human potential, etc. It is also emphasized that these problems are reflected both in the growing costs of a company's activities and in climate change. However, more and more companies are becoming aware of these dangers and are implementing new products, new technologies and processes that use less raw materials and energy, being more environmentally-friendly. The purpose of implementing new solutions of production is to improve labour mobility, optimise the use of raw materials and resources, reduce costs, and to increase efficiency, productivity, etc.

Taking the impact of operating activities on the environment into account, the purpose of this chapter is to present selected production methods from their cognitive aspects, the assumptions of which are consistent with the issues of sustainable development. In particular, focus was placed on the zero-waste concept, which allows to eliminate waste in all links of the value chain. Lean manufacturing and six sigma, which help enterprises fight waste in their activity, as well as circular production related to the implementation of closed-loop production principles in practice, are discussed. In addition, the life-cycle product design and recycling, as well as green and environment-conscious manufacturing are presented. The first of them assumes that the possibility of recycling should be considered in the process of designing products and services. The second one should be identified with a modern and systemic way of managing enterprises, taking all environmental aspects into account by all departments.
\end{abstract}

Keywords: industry, production, production methods, sustainable production, waste, waste reduction. 


\subsection{Sustainability in operational management: theoretical background}

Operational management $(\mathrm{OM})$ is one of the most important functions of modern enterprises. It should be defined as "the design, control, operations, and improvement of the systems that create and deliver the firm's primary products and services" (Johnston, Chambers, Harland, Harrison, \& Slack, 2002, p. 24). In a broader sense, it is understood as "a value- and quality-adding approach and philosophy to planning, organising and controlling organisational resources or input for optimum results in terms of efficiency and customer expectations. Operational management is viewed as a systems-oriented and highly integrative study of methods, tools, processes and techniques that coordinate "'the vital three' (people, systems and processes) with 'the central one' (physical and natural resources) in creating and adding value to meet organisational goals and customer requirements at an appropriate cost of acquisition, production, and distribution" (McFarlane, 2014, p. 16). It is related to the analysis of needs, opportunities, supplies and processing methods. In practice, it is often equated with the company's core activity, involving the conversion of production factors into a finished product or service. It further requires the involvement of various types of resources, such as: raw materials, materials, machinery, capital, information, energy and the human factor. The indicated elements constitute the company resources that should be properly managed. It is believed that their effective management is one of the most important challenges facing modern enterprises. The scale and scope of undertaken economic activities contribute to the consumption of huge amounts of resources, which is reflected in the climate change, mainly through the emission of greenhouse gases, liquid and solid wastewater. As a result, enterprises contribute to disruptions in sustainable development, the consequences of which will become apparent in the future (Corbett, 2009). The practices implemented nowadays demonstrate various problems related to operating activities. Those particularly important are waste of resources, mismanagement, excessive energy consumption, environmental pollution, exploitation of human potential, etc. In their operations, companies must also consider changes (both evolutionary and radical) in a hyper-competitive environment that is constantly changing. Globalisation, climate change, environmental degradation, resource depletion, technological progress, as well as increasing consumer awareness, force companies to implement strategies based on sustainable development. The identification and recognition of changes should be reflected in the set of activities, within which it is necessary to find, develop and use new, innovative methods and processes which, on the one hand, will eliminate the threat, and on the other, will allow 
to create new value, based on a better, more economical and more rational use of resources.

The concept and significance of sustainable development (SD) were highlighted by the World Commission on the Environment and Development in 1987. It has been defined as "development that meets the needs of the present without compromising the ability of future generations to meet their own needs" (Brundtland, 1987, p. 8). According to Fredriksson and Persson (2011), such an approach covers social, ecological and economic problems. The economic aspect is focused on ensuring profitability in the short- and long-term. The social one refers to promoting social development and improving quality of life. The ecological problem aims at minimising the negative impact of human activities on the environment and protecting natural resources.

Gladwin, Kennelly and Krause (1995, p. 878-879), however, on the basis of a literature analysis, indicated that $\mathrm{SD}$ is described by 5 elements:

- inclusiveness, related to an expansive view of space, time and its components;

- connectivity, indicating that the problems of the modern world, including those economic, social and environmental, should be treated as interdependent and systemically related;

- equity, according to which the distribution of resources and property rights, both across generations and between generations, should be based on the principle of equity;

- prudence, which should be understood as striving towards maintaining the resilience of ecosystems, and to maintain the scale of human impact on the environment at a level that allows its regeneration and reconstruction;

- security, focused on people as well as their needs, and ensuring a safe and adequate quality of life, both for present and future generations.

Therefore, it can be emphasized that there are many interactions between operational management and sustainable development (Fredriksson \& Persson, 2011). Both approaches are interested in technological, social, economic, environmental, and even legal and demographic issues. It is pointed out that the main issues considered by both approaches are reduction in the consumption of natural resources and the amount of waste in production processes, as well as increasing efficiency in terms of environmental and cost challenges. The interaction between operational management and environmental aspects is presented in Table 1.

In practice, it is emphasized that the implementation of the $\mathrm{SD}$ concept requires solving 34 issues (Mulder, 2006):

- significant reduction in resource consumption;

- elimination of non-renewable resource consumption cycles from production processes;

- focusing primarily on the use of resources and renewable energies. 
Table 1. Intersections between $\mathrm{OM}$ and environmental concerns

\begin{tabular}{|l|l|}
\hline \multicolumn{1}{|c|}{ Operations management } & \multicolumn{1}{c|}{ Aspects related to environmental concerns } \\
\hline Manufacturing perspective & $\begin{array}{l}\text { Amount and type of waste as well as supportive materials; } \\
\text { (Re-)use of heat, supportive materials, etc.; } \\
\text { Location and use of plants; } \\
\text { Use of management systems (e.g. EMAS, ISO14000, 14001, etc.) } \\
\text { for pollution reduction and prevention. }\end{array}$ \\
\hline Product development perspective & $\begin{array}{l}\text { Amount of material used to realise functionality; } \\
\text { Ratio of new/old material used; } \\
\text { Material characteristics (toxicity, scarcity, etc.); } \\
\text { Product architecture (modularisation); } \\
\\
\text { Use of life-cycle assessment for analysis. }\end{array}$ \\
\hline
\end{tabular}

Source: (Fredriksson \& Persson, 2011, p. 238).

The implementation of the postulates given above, requires the involvement of both the society, state and local governmental bodies, enterprises, as well as other institutions. From the point of view of enterprises, it is therefore necessary to implement Sustainable Operations Management (SOM). This concept covers issues related to closed-loop chains, the green supply chain, green procurement, carbon footprinting of supply chains, life-cycle management, greening supply chains, green and reverse logistics, product and process development towards improving energy saving, efficiency of transport and other related areas (Gunasekaran \& Irani, 2014, p. 801). The solution to the above problems requires the proper design of operations, organisation of resources, assessment of inter-organisational cooperation as well as analysis and comparison of asset productivity and labour efficiency. In the operations of enterprises, SOM becomes a key skill that effectively contributes to the development of sustainable supplies based on reliable relationships. It allows to improve the speed of response to customer needs, implement flexible production systems, reduce production costs, while protecting natural resources for future generations.

Sustainable Operations Management can be defined as the operations strategies, tactics and techniques and operational policies to support both the economic and the environmental objectives and goals (Gunasekaran \& Irani, 2014, p. 802).

Opresnik and Taisch (2015) indicate that companies wanting to include SD in their activities, must formulate an appropriate operational strategy. This can be defined as a "major decision about, and strategic management of: core competencies, capabilities and processes, technologies, resources and key tactical activities necessary in any supply network, in order to create and deliver products or services and the value demanded by a customer" (Bettley \& Burnley, 2008; Opresnik 
\& Taisch, 2015, p. 534). The basis of this strategy comprise 2 challenges. The first one concerns the ability to connect a business with the environment; while the second one is its implementation. Within its framework, many activities should be undertaken, concerning both production, market and legal aspects. Such a strategy allows to reconfigure the business model. With its implementation, the new needs, challenges, benefits and perspectives emerge.

In an enterprise, SD in can be positioned at 2 levels: strategic and operational. In the first approach, this can be treated as a tactic supporting the main strategy; in the second one, it is a specific decision pattern influencing the current activity. It allows to identify operations that should be implemented, their importance in the production process and pattern of usage. Thus, sustainable development depends on individual operations which means that they have lasting impact on a specific part of the value chain.

Operational sustainability must be properly managed. This management consists of 2 distinct steps: strategy formulation and its implementation. Such an approach allows to examine the problem from 2 perspectives: prescriptive and normative. The first one answers the question as to "how things are done", while the second one- "how things should be done" (Opresnik \& Taisch, 2015, p. 535). The process of formulating and implementing sustainable development in the operating activities is presented in Figure 1.

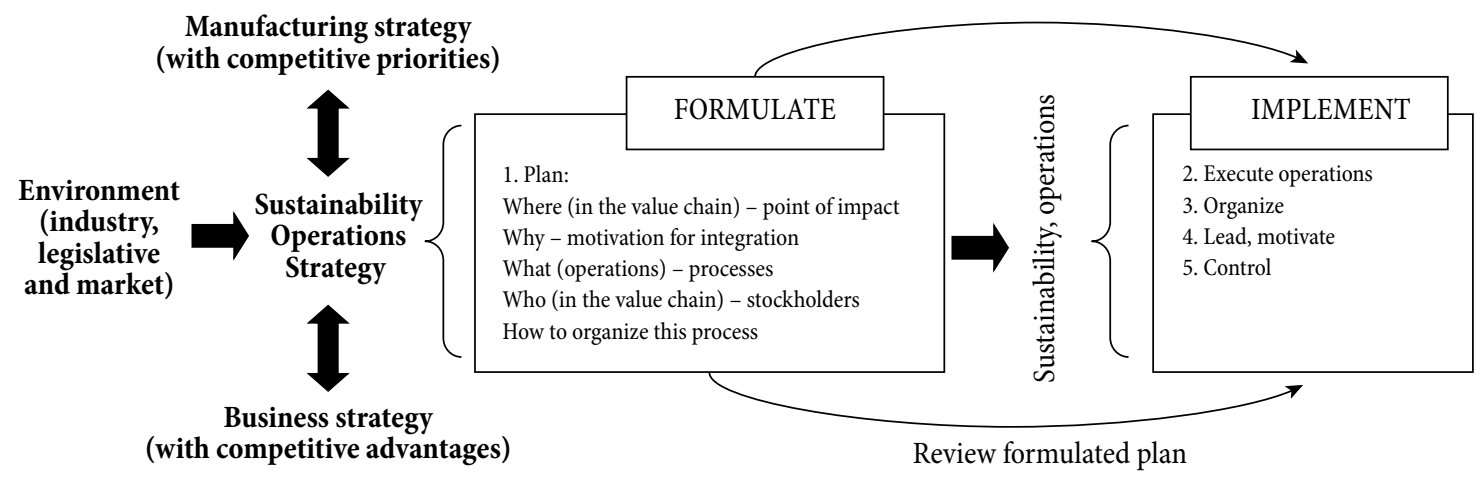

Figure 1. Sustainability in operations management

Source: (Opresnik \& Taisch, 2015, p. 535).

Enterprises implementing the SD idea can use various methods and tools. These methods focus on aspects such as: production planning and control, organisation, next-generation production, processes, the use of supporting software, human factor, costs, product design, and ecological aspects. Their common feature is the pursuit of production based on limiting and preventing waste. 


\subsection{Zero-waste concept in operations management}

With the processes of globalisation, technological progress and the growing purchasing power of individual societies, lifestyle changes. That current is based on saving and long-term use, and has radically transformed towards maximising consumption. Many products, such as household appliances and electronics, clothes, means of transport, and even some food products that were previously considered luxurious, are now used as basic goods (Crocker, 2013). There has been a dynamic development of consumerism, through which we should understand the moral doctrine viewing consumption as a way of achieving happiness, joy in life, the possibility of satisfying both physical and spiritual needs and desires (LewickaStrzałecka, 2003). It has also contributed to changes in the operational activities of enterprises which use composite and hazardous materials in their production processes. The waste generated during these processes is usually disposed of at landfills. These include electronic products, post-production scrap, chemicals, various types of polymers as well as animal and vegetable waste. Their number and multiformity simultaneously contribute to environmental pollution which is increasingly degraded. Factors influencing the shape, quantity and quality of waste are presented in Figure 2.

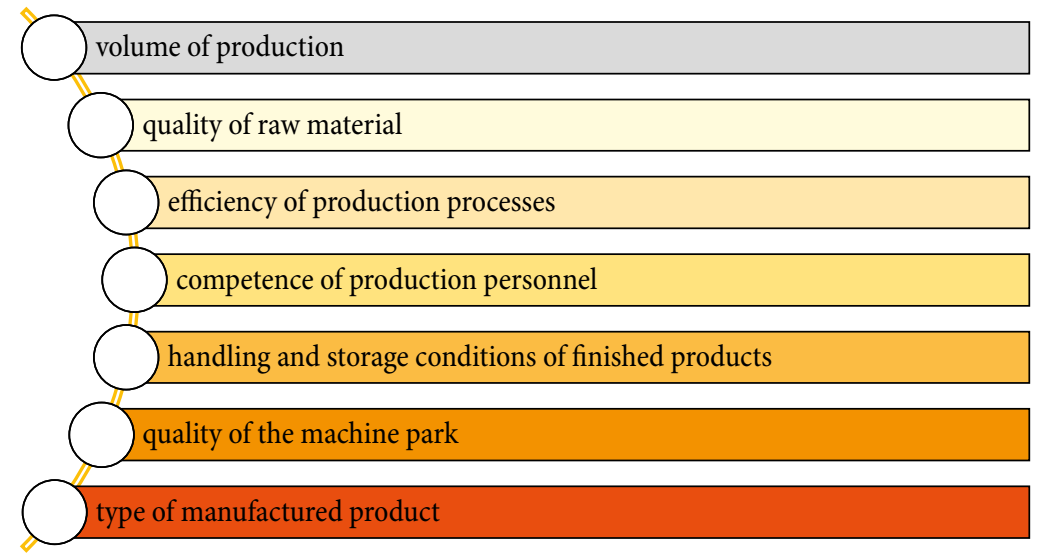

Figure 2. Factors influencing the shape, quantity and quality of waste

Source: Own research based on (Ohaegbunam, 2015).

Many companies recognise the problem and take various actions to completely eliminate waste in all links of the value chain. On the one hand, the aim is to limit the use of various raw and other materials, while on the other, to reuse waste, eliminate shortages in production process and other residues generated in production processes. Such an approach is related to the zero-waste concept, which can be most 
simply defined as the minimisation of waste during production and consumption processes. This presents a challenge and a new goal of redesigning the entire system, related to the flow of resources and materials through the production process. This approach allows to maximise use, as it is assumed that the manufactured products can be reused, repaired, recycled or returned to the environment without any negative impact. The concept, thus defined, assumes a complete redesign of the industrial system in which the environment should no longer be perceived as an endless source of material supplies (Tennant-Wood, 2003, p. 47).

The zero-waste concept is, therefore, based on minimising the production of all kinds of waste, which directly affects the reduction of waste and environmental safety. The zero-waste concept indicates the need to sort waste, be responsible for its generation, implement storage fees depending on its quantity and the possibility of its management. There should also be a system of incentives and stimuli to implement the concept and, at the same time, a set of disincentives.

Zero-waste is a goal that is ethical, economical, efficient and visionary, created to guide people in changing their lifestyles and practices to emulate sustainable natural cycles, where all discarded materials are designed to become resources for others to use. ZW means designing and managing products and processes to systematically avoid and eliminate the volume and toxicity of waste and materials, conserve and recover all resources, and not burn or bury them (ZWIA, 2009).

Apart from environmental aspects, entrepreneurs also pay attention to the costs related to waste. More and more manufacturers are beginning to recognise that waste generates costs in both entry and exit. In the first case, they are incurred at the time of purchasing raw materials and materials for production, in the second one, when discarding production residues. Therefore, the implementation of the zero-waste concept reduces production costs, improves financial results and enables better competitive position. Such an approach also helps to achieve goals related to the sustainable development (Zero-waste manufacturing, 2014).

The implementation of the zero-waste concept generates a significant number of problems. They are connected with the necessity to incur capital expenditures, reconfigure production processes and programmes, and change the mentality of staff. Traditionally, waste is easily identifiable as it consists mainly of physical substances that are easy to observe and measure. In the case of operation management, waste assumes a more abstract form that can be identified on the basis of labour efficiency analysis, i.e. comparing input (raw materials, labour, time, production process) with all identifiable effects, including finished products, inventory, waste, profits, etc. (Ohaegbunam, 2015). In practice, enterprises can use 2 methods, i.e. lean manufacturing and six-sigma, both of which facilitate the management of operations and enable the identification, elimination and improvement of waste quality (Zero-waste manufacturing, 2014). 


\subsection{Lean manufacturing and six-sigma in sustainable development}

Analysing the operational activity of an enterprise, the following types of waste are of particular importance (Wiśniewska, 2005, p. 24):

- overproduction-understood as production exceeding and prior to establishing customer needs;

- waiting-i.e. idle production, in other words, hidden unproductivity caused by delayed delivery of materials or machine failure, planning errors, etc.;

- excessive processing-redoing activities or returning to activities that have already been done earlier at previous stages;

- excessive transport-carrying out transport activities above the expected level;

- excessive stocks-purchase over demand, storage of additional parts or products that the customer does not currently need. In other words, this problem is related to the capital frozen in articles or work completed and waiting for its turn;

- excessive traffic-all additional or too long-lasting activities needed to complete a task;

- errors and defects of products, or otherwise, production deficiencies;

- unused human potential, including wasting employee creativity.

The presented approach is primarily associated with production aspects, however, it should be noted that waste also affects the non-production sphere, associated with organisational, administrative, legal work, etc., as presented in Figure 3.

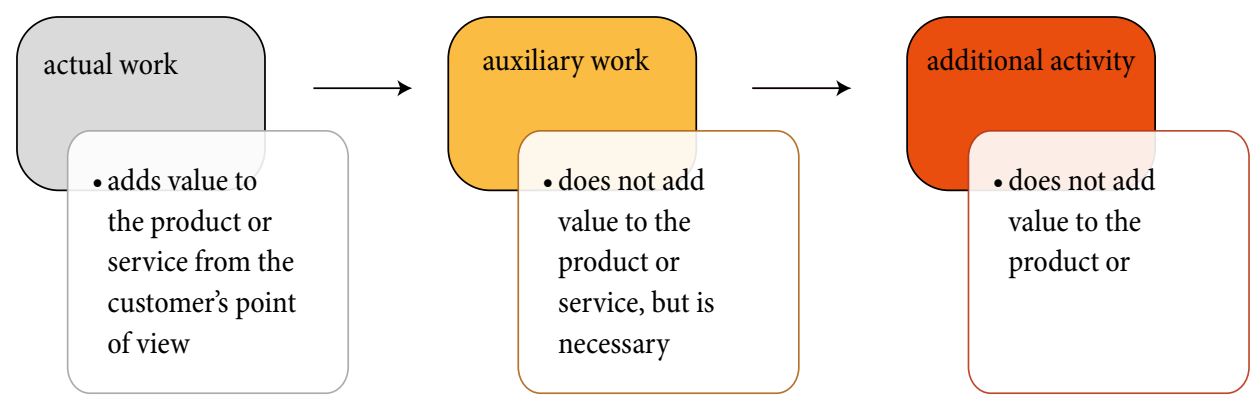

Figure 3. Work components

Source: Own research based on (Manos \& Vincent, 2012).

Lean manufacturing and six-sigma are methods that help a company fight waste in its operations. The first one enables the identification and elimination of waste in the production process, while the second is focused on the reduction of defects in production, which directly improves the quality of products and services. 
Lean manufacturing is defined as a specific concept and philosophy of production management, the aim of which is the maximum elimination of waste, unnecessary procedures, activities and processes, while ensuring maximum value for the customer (Halevi, 2001). The implementation of the method allows to scale up production with less consumption of materials, time and space, as well as better use of production capacity and manpower. It covers all activities related to the product, from its design to the transformation of raw materials, and materials into a finished product as well as the management of all information related to the organisation of procurement and distribution (Womack \& Jones, 2003).

Lean manufacturing is an action strategy which is aimed towards efficient material flow and improved use of resources through elimination, reduction and control of waste (Modig \& Åhlström, 2013).

The concept of sustainable development covers 3 problems: economic, social and ecological. They are influenced by production processes affecting both the social development and improvement of quality of life, the environment through its exploitation and pollution, as well as economic aspects, viewed through the prism of profitability. Therefore, the goal is to implement measures that will not have negative effects on any of the above aspects. This can be achieved through implementation of sustainable production, which is a specific combination of lean manufacturing and sustainable development, meaning "the creation of goods and services using processes and systems which are non-polluting, conserving of energy and natural resources, economically viable, safe and healthful for employees, communities and consumers, and socially and creatively rewarding for all working people" (Lowell Center for Sustainable Production, 1998).

Thus, it can be emphasized that lean manufacturing is closely related to sustainable development and contributes to its strengthening from the various perspectives (Järvenpää \& Lanz, 2020). In particular, there is reduction in the amount of generated waste, as well as the desire to use materials and raw materials used for the production processes in a closed loop. The assumptions of the concept can also be used as guidelines in the formulation of manufacturing and sustainable ecological strategies. Järvenpää and Lanz (2020), analysing the relationship between lean management and sustainable development, indicate that reducing the amount of waste generated in the production processes affects the economic and social sustainability. Appropriate organisation of the workplace, improvement of safety, tidiness and order, as well as involvement in improvement activities positively, influence the perception of a company by various stakeholders. Such activities are directly reflected in the employees' approach to work, who show greater commitment and care for the assets entrusted to them. As a result, the company can offer better-quality products while reducing costs (see Figure 4). 


\section{7.}

Dariusz Nowak

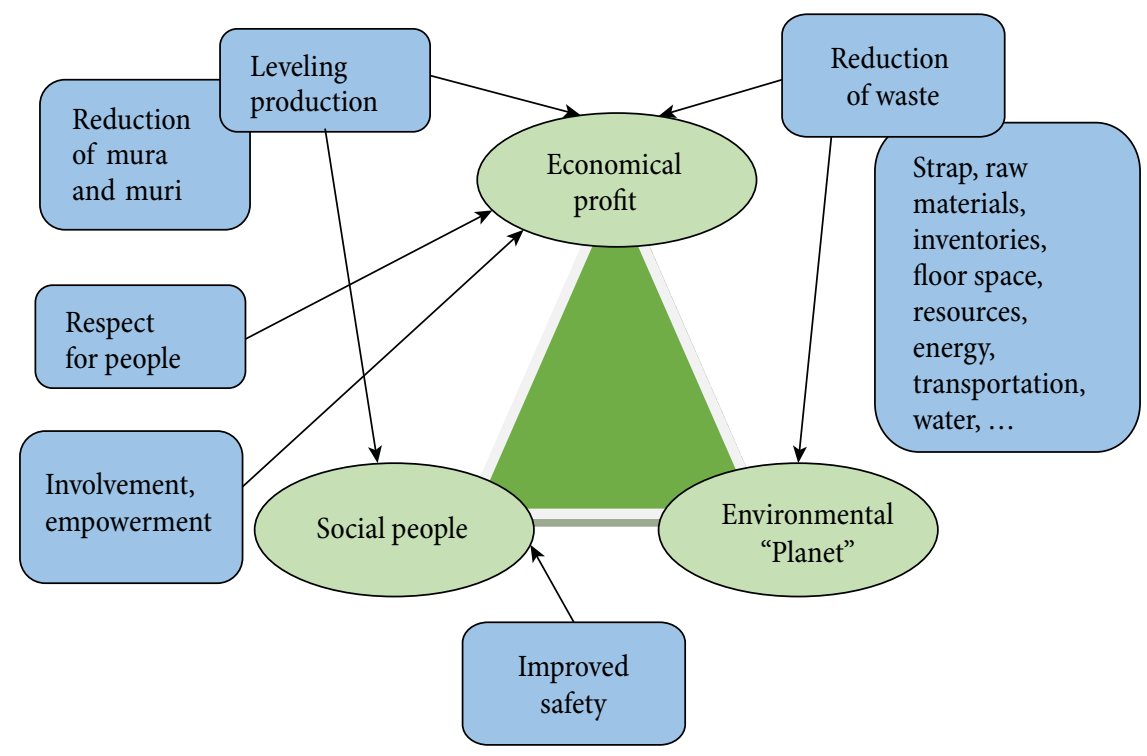

Figure 4. Support of lean to sustainable development

Source: (Järvenpää \& Lanz, 2020, p. 7).

The relationships between lean manufacturing and sustainable development include correlation, overlapping areas, difference, integration and classification based on sustainability dimensions. This relation is reflected both in the improvement of efficiency as well as in environmental and economic aspects (Hartinia \& Ciptomulyonob, 2015).

Six-sigma is a modern management method based on continuous data acquisition and analysis in order to achieve excellent quality. The essence of the method is to identify errors before they occur. This involves continuous monitoring and control of all processes and procedures, which allows to eliminate and prevent various types of discrepancies between the expected product and its actual image. In practice, the implementation of the concept is associated with a permanent reduction in costs that arise when the quality deviates from the original assumptions. The assumptions of the concept fit directly into the idea of sustainable development, especially in terms of reducing waste, increasing efficiency and improving the efficiency of an organisation and all procedures, processes, operations, etc. The main advantages of six-sigma include elimination of variability, ensuring customer satisfaction, reducing the duration of production cycles, reduction in costs related to the correction of errors, repairs, production shortages, as well as improvement of the company's competitive position. These effects can be achieved by defining, measuring, analysing, improving and controlling (DMAIC) all structures of a given organisation (this is shown in Figure 5). This, in turn, enables effective 
management of the production programme, transfer, measurement systems, and further allows risk assessment and designing processes enabling environmental sustainability (Kadry, 2013).

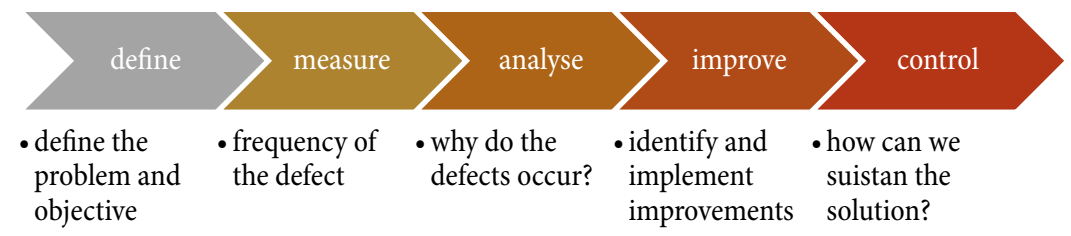

Figure 5. Methods of six-sigma

Source: Own research.

It is emphasized that by implementing the assumptions of the six-sigma concept into practice, enterprises achieve better environmental results. They can focus on reducing the amount of waste, and they also use ecological management tools, which contributes to "green thinking". Linking six-sigma techniques and tools to sustainable development should contribute to (Magraner, 2019):

- maintaining a clean and organised work environment;

- reducing the consumption of input needed to perform operational tasks and motivating the staff to correctly identify and remove production waste;

- optimising the use of raw materials and materials, and preventing the formation of unnecessary, excessive and unjustified inventories;

- improving the operation of the machine park as well as energy and material efficiency;

- appropriate waste management;

- paying attention to environmental problems and engaging in solving them;

- implementing and using new tools to understand and solve problems related to sustainable development;

- identifying and reducing defects, both in production processes and in the final product, which reduces environmental waste;

- organising appropriate working conditions, ensuring safety, and thus reducing the number of accidents at work.

From an ecological point of view, six-sigma influences a more efficient use of resources, reduces waste and pollution, and thus, decreases negative impact on the environment. In economic terms, it can ensure the loyalty of buyers, a reliable market, increase profits and improve the reliability of the machine park, processes, procedures, etc.

It should be emphasized that specific solutions related to both lean manufacturing and six-sigma depend on the sector, type of enterprise, production techniques used, machine park, workforce, applied raw materials, etc. Heavy industry 
enterprises, such as shipyards, mines or steel mills, assume different approaches to the problem of sustainable development than companies focusing on the production of consumer goods, with modern, innovative equipment.

\subsection{Circular production}

By implementing goals related to sustainable development, the enterprises can apply the principles of closed-loop production in their operating activities. This method completely changes the way an economic entity functions, its philosophy, perspectives, and the way it is perceived by the environment. This contributes to the creation of a completely new model of resource management, dealing with its lack of value creation as well as a policy in the field of procurement, safe-keeping and storage of materials. It is also reflected in the principles of employing, motivating and remunerating employees, especially those directly in production.

Circular production is identified with a production and consumption model in which raw materials, materials, semi-finished products as well as other components used in production processes and finished products remain in circulation as long as possible (Geissdoerfer, Pieroni, Pigosso, \& Soufani, 2020). For this purpose, many activities are used, including: joint using, sharing, leasing, repairing, reusing, refurbishing, reconditioning, etc. If certain resources and products cannot be used any further, they should be recycled to recover raw materials and be reprocessed. Therefore, it may be emphasized that raw materials, materials and various components used in production processes lose their value to a very small extent, and over a long time 'horizon'. By implementing the ideas of closed-loop production, renewable energy sources are also used. Thus, circular production contributes to the development of sustainable production and consumption. Its main advantages are reduction in various types of waste and energy saving, which is reflected in the decrease in air, water and land pollution. This approach is the complete opposite of the traditional, linear economic model, based on the principle of "take-makeuse-dispose" (Andrews, 2015). Circular production is considered to be comprised on the foundation of 3 components: closed cycles, renewable energy and systems thinking (Korhonena, Nuurb, Feldmannb, \& Birkie, 2018).

The material circulation of circular production is based on the principle of an ecosystem where there is no residue, everything is biodegradable. This means that in production processes, all waste, whether solid, liquid or gaseous, can be reused, e.g. in the production of a new product. Toxic substances and materials generated in the production process should be eliminated or neutralised (the process of circular economy is shown in Figure 6). The basic principle of closed cycles is the receipt of manufactured products by their producers from their users after the period of use, and then, their renewal or processing with maximum use of components. It 
can therefore be emphasized that an extremely important issue is the appropriate design of a product, the components which should, on the one hand, be of high quality, and on the other, be easily recyclable (Korhonena et al., 2018).

In today's world, energy is an extremely significant problem, especially that generated from traditional raw materials such as lignite and hard coal, oil or gas. Hence, a change that will contribute to the use of renewable energy sources is necessary, i.e. energy that does not harm the environment and does not run out quickly. This issue is greatly significant for circular companies, as energy cannot be recycled and is not subject to a recurring cycle. In practice, companies can use sun, water, wind, geothermal energy and biofuels.

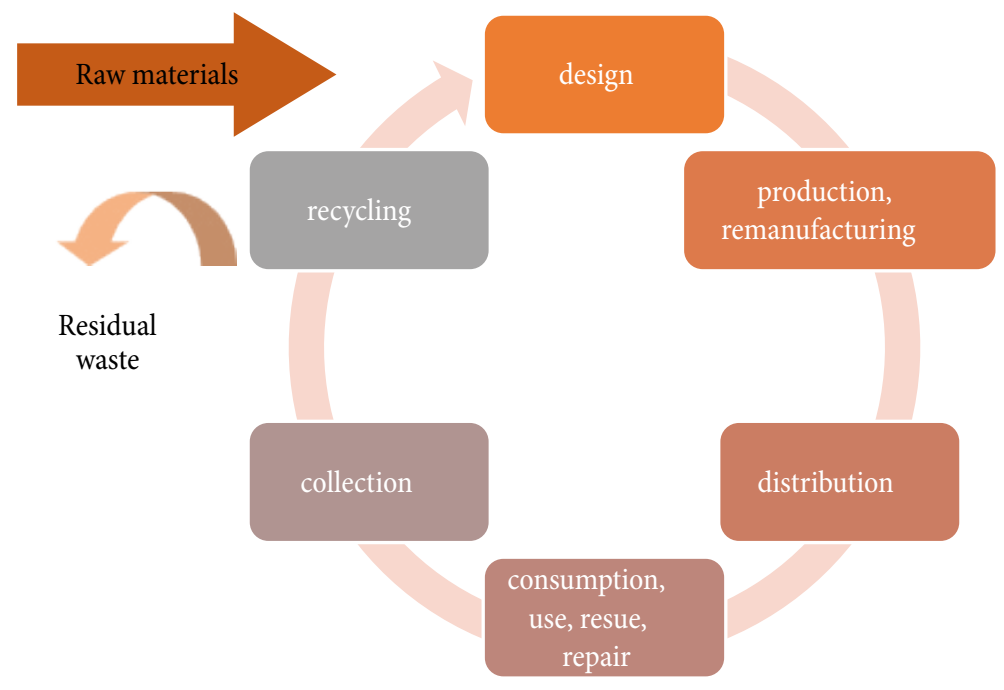

Figure 6. Processes of circular economy

Source: Own research.

The final element of the circular economy is systems thinking, which should be understood as "discovering patterns of connections and dependencies among seemingly unrelated beings (events, processes, things, beings). It is often associated with descriptions such as holistic, deep or process thinking" (Zych, 2013, p. 16). Today, there are no closed-loop enterprises. Achieving goals requires collaboration which means that each enterprise is part of a larger network. The actions of each participant influence the remaining actors. When implementing the postulates of a closed economy, one should look for and cooperate with such partners who follow similar patterns of behaviour, rules of conduct, or are characterised by a proenvironmental organizational culture.

The implementation of closed production principles brings many benefits, both for the company, society and the entire economy. It allows to reduce the use of 
natural resources, which further contributes to cost saving, generation of growth and optimisation of employment. It also influences the identification of new opportunities, stimulates innovation and improves competitive position. As a result, it has a positive effect on the environment, both from the point of view of climate change and its pollution (Circular economy: definition, importance and benefits, 2020).

\subsection{Life-cycle product design and recycling}

The production method known as life-cycle product design and recycling, also fits perfectly into the issues of sustainable development. The concept assumes that the recycling options should be considered in the process of designing products and services. This approach assumes that already at the conceptual stage, it is ensured that environmental pollution is avoided in the future and that benefits are obtained after final withdrawal of the product from the market (Halevi, 2001). A product, the design of which is based on life-cycle, contributes to maximum use of raw materials and materials. At the same time, it leads to the minimisation of economic, social and environmental efforts during the products' life-cycle (Zbicinski, Stavenuiter, Kozlowska, van de Coevering, 2006).

Life-cycle product design and recycling is defined as the environmentally-friendly process of designing a product or service, taking all life phases into account, from designing, sourcing and using raw materials, to supply, production and distribution, and ending with the use of materials and components after product withdrawal from the market (Summary Final Report, 1995). In the design process, particular attention should be paid to components and materials that can be used in the future. Not all of them will find their application, especially in the case of traditional raw materials that have already been depleted. Moreover, technical progress and technological development, especially regarding recycling and processing of secondary raw materials, should be regarded. It may turn out that today's difficulties with recovery will not be of great importance in the perspective of a few or several years. Attention should also be paid to the future environmental, economic, social and legal conditions. When designing a product or service, all actors directly or indirectly related to the product should be considered, including contractors, subcontractors and users.

It is additionally emphasized that when designing a new product, there are many different types of problems. They concern both the complexity of products and services, the variety of raw materials used, various types of components with a harmful effect on the environment, and partners who will perform specific work and tasks. Cooperation with subcontractors who will not always take into account or be able to meet the requirements specified in the Project, is particularly important. Production capacity and quality of production potential are starting to become 
problematic. An significant issue is also the logistics related to product collection and recycling, especially if they were intended for a dispersed consumer market. In practice, there is no system of stimuli or incentives that would persuade users to return worn and used products, especially those of small size and cost, that can be simply thrown away. In the Summary Final Report (1995), it has been indicated that life-cycle product design and recycling are associated with several complex problems:

- reduction in product quality due to the use of environmentally-friendly materials with worse parameters, which contributes to shortening service life;

- recycled materials, reused in production processes, are often characterised by worse quality parameters, such as durability or resistance to external factors, which shortens their useful life span;

- recycling recovered and raw materials requires the involvement of additional funds, including energy, making it uneconomical and unprofitable in some cases;

- various types of components, solutions or materials with a harmful effect on the environment are often used in the recycling processes, which raises a number of ecologically-related doubts;

- there is a possibility of environmental pollution with unknown and harmful substances that have been added to the product by their users, especially industrial ones;

- in some cases, there is no interest in recycling from subcontractors, users or companies dealing with material recovery (e.g. due to low profitability).

Analysing the indicated threats, particular attention should be paid to companies that deal with recycling and disassembly. They must be equipped with a special technology that, on the one hand, will enable the recovery and processing of raw materials, and on the other, will meet qualitative and quantitative requirements, ensuring trouble-free operation, without negative impact on the environment. The appropriate co-operation between the manufacturer, user and recycling company is therefore required as well as compatible reciprocal information exchange.

\subsection{Green and environment-conscious manufacturing}

Green and environmentally conscious manufacturing comprise another group of methods used in the operational activities of enterprises that enable the implementation of the sustainable development idea.

Green manufacturing (GM) should be equated with a modern and systemic way of managing an organisation in which all cells are managed with regard to environmental aspects. The key elements of GM are presented in Figure 7. From a production point of view, the term is defined as "practices that produce environmentally-friendly products and minimize the impact on the environment 
through green production, green research and development, and green marketing" (Peng \& Lin, 2008). Loknath and Azeem (2017) indicate that the above terms should additionally be supplemented with continuous improvement, sustainable development and innovation. According to the authors, GM is also associated with environmental management and sustainable corporate development because apart from reducing waste and pollution, the ideas of green management should also be taken into account.

Green manufacturing is the organisation-wide process of applying innovation to achieve sustainability, waste reduction, social responsibility, and a competitive advantage via continuous learning as well as development, and by embracing environmental goals and strategies that are fully integrated into the goals and strategies of the organisation (Loknath \& Azeem 2017; Haden, Oyler, \& Humphreys, 2009).

Activities undertaken within the GM concept consist of 4 phases: those conceptual, preparatory, production-related and final (Skibinska \& Kott, 2015). In the first phase, analysis of the company's environmental impact should be conducted, and then, appropriate systems should be implemented, in which the results of the analysis are included. The second one defines GM goals and criteria, and develops new methods. Particular attention should be paid to the division of tasks, responsibilities, controlling and the incentive system. In the production phase, so-called green control is conducted, allowing to identify and assess the amount of generated waste and pollution. The results of control are taken into account during the procedure in which the plan for the optimal use of energy and resources should be presented. In the final phase, the principles and rules for exploiting the organisation's potential with lower energy and resource consumption should be developed (Skibińska \& Kott, 2015).

The implementation of the GM concept brings many benefits to the company, in particular, it reduces the cost of raw materials. A company recycling materials it had previously purchased does not have to incur costs for their repeated purchase. Moreover, GM influences the increase in production capacity, work efficiency and better use of production potential, while being cost-effective with regard to environmental expenses and ensuring work safety. By using less hazardous materials, savings are made on their transport and disposal (Askew \& Desai, 2018).

Environmentally conscious manufacturing (ECM) is "the deliberate attempt to reduce the ecological impact of industrial activity without sacrificing quality, cost, reliability, performance, or energy utilization efficiency. The principle of environmentally conscious manufacturing is to adopt those processes that reduce the harmful environmental impacts of manufacturing, including minimization of hazardous waste and emissions, reduction of energy consumption, improvement of materials utilization efficiency, and enhancement of operational safety" (Halevi, 2001, p. 150). 


\section{7.}

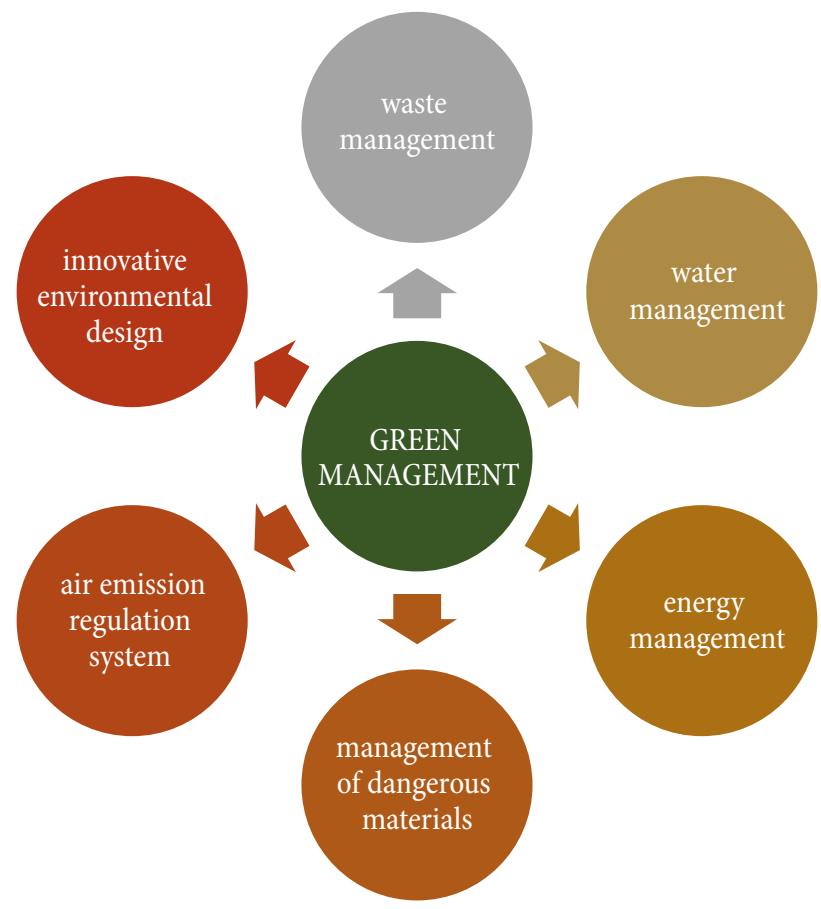

Figure 7. Key elements of green manufacturing

Source: (Aydin, Yaldiz, \& Buyuksahin, 2017).

Halevi (2001, p. 150) points out that more and more enterprises are becoming "ecologically aware", and when implementing new products, technologies or processes, they take such aspects as saving energy, water and natural resources into account.

Environmentally conscious manufacturing (ECM) is concerned with developing methods for manufacturing new products, from conceptual design to final delivery and ultimately, to end-of-life (EOL) disposal, so that environmental standards and requirements are satisfied (Gungor \& Gupta, 1999, p. 812).

The main assumption of the ECM concept is to minimise harmful impact on the environment throughout the entire production cycle and entire product life-cycle, which should ultimately contribute to the more efficient use of resources. Its scope covers all functions related to the production of a product or service, from planning and procurement, to the development and organisation of production processes, ending with packaging, transport and disposal. It is assumed that each process will eliminate or significantly reduce waste emission and production shortages. In addition, operational safety should be improved, and the manufactured product, 
after its useful life, can be recycled or regenerated for reuse (Yusuff, Vahabzadeh, \& Panjehfouladgaran, 2012). All activities are undertaken within the context of reducing or minimising the amount of solid, liquid and gaseous pollutants. Therefore, the stage of designing a product, process or technology is particularly important, as during which, the potential and capabilities of the enterprise, as well as internal and external conditions, should be taken into account. In particular, attention should be paid to (Halevi, 2001, p. 151):

- the project of product disassembly and disposal after its useful life, reducing the amount of waste and obtaining recycled material;

- pro-ecological production - thanks to the use of newer and more environmentally-friendly technologies, production processes and efficiency are improved, while production capacity increases, etc.;

- comprehensive quality and environmental management, which means that one should strive for harmony between the company and the environment, and not treat the latter as only a supply of resources;

- industrial ecosystems which are interconnected companies with a similar proecological approach, thanks to which waste generated in one enterprise can be used as a raw material for a partner;

- technology, through the prism of its impact on the social, economic and ecological environment, with particular emphasis on the possibility of recycling the materials used.

In order to take the above postulates into account, a company must implement an appropriate design process. In practice, the life-cycle assessment (LCA) technique is used. It is a method that focuses on all environmental aspects of the production, including use, disposal and potential reuse (Halevi, 2001). LCA analysis considers all phases of the product life-cycle, from raw material acquisition, to production, distribution and use, ending in disposal. Therefore, it enables reporting the potentially negative environmental impact at each stage of the product or service supply chain.

\section{Questions / tasks}

1. Please discuss the narrow and broad meaning of operational management?

2. What are the problems related to the company's operational activity?

3. What is the relationship between operational management and sustainable development?

4. Explain the concept of Sustainable Operations Management.

5. Discuss the stages of managing sustainable development in operational activities.

6. What is consumerism?

7. What factors influence waste in production processes? 
8. Explain the assumptions of the zero-waste concept in operating activities.

9. What is waste and what types of waste in an enterprise do you know?

10. What is the difference between lean manufacturing and six-sigma?

11. Discuss the assumptions of lean manufacturing.

12. Discuss the assumptions of six-sigma.

13. What are the effects of linking six sigma principles to sustainable development?

14. What is circular production?

15. Discuss the process of circular economy.

16. What are the benefits of a company operating according to the circular-economy concept?

17. What are the assumptions of life-cycle product design and recycling?

18. What are the problems related to life-cycle product design and recycling?

19. What is green manufacturing?

20. What is environment-conscious manufacturing?

21. What phases can be identified in green manufacturing?

\section{References}

Andrews, D. (2015). The circular economy, design thinking and education for sustainability. Local Economy, 30(3).

Askew, L., \& Desai, A. (2018). Green and environment conscious manufacturing and management techniques. Industrial and Systems Engineering Review, 6(1).

Aydin, D., Yaldiz, E., \& Buyuksahin, S. (2017). Sustainable hospital design for sustainable development. $8^{\text {th }}$ International Conference on Urban Planning, Architecture, Civil and Environment Engineering. Dubai.

Bettley, A., \& Burnley, S. (2008). Towards sustainable operations management integrating sustainability management into operations management strategies and practices. In K. Misra (Ed.), Handbook of performability engineering. London: Springer.

Brundtland, G. H. (1987). Our common future: The world commission on environment and development. Oxford University Press.

Circular economy: definition, importance and benefits. (2020). News-European Parliament. Retrieved December 2, 2020 from https://www.europarl.europa.eu/news/en/headlines/economy /20151201 STO 05603/circular-economy-definition-importance-and-benefits

Corbett, L. M. (2009). Sustainable operations management: A typological approach. Journal of Industrial Engineering and Management, 2(1).

Crocker, R. (2013). From access to excess: consumerism, 'compulsory' consumption and behaviour change. In S. Lehmann, \& R. Crocker (Eds.), Motivating change: Sustainable design and behaviour in the built environment. London: Earthscan Publication.

Fredriksson, P., \& Persson, M. (2011). Integrating sustainable development into operations management courses. International Journal of Sustainability in Higher Education, 12(3).

Geissdoerfer, M., Pieroni, M. P. P., Pigosso, D. C. A., \& Soufani, K. (2020). Circular business models: A review. Journal of Clenear Production, 277.

Gladwin, T. N., Kennelly, J. J., \& Krause, T. S. (1995). Shifting paradigms for sustainable development: Implications for management theory and research. Academy of Management Review, 20(4). 
Gunasekaran, A., \& Irani, Z. (2014). Sustainable operations management: design, modelling and analysis. Journal of the Operational Research Society, 65(6).

Gungor, A., \& Gupta, S. M. (1999). Issues in environmentally conscious manufacturing and product recovery: a survey. Computers \& Industrial Engineering, 36.

Haden, S. P., Oyler, J., \& Humphreys, J. (2009). Historical, practical, and theoretical perspectives on green management: An exploratory analysis. Management Decision, 47(7).

Halevi, G. (2001). Handbook of production management methods. Oxford: Butterworth Heinemann. https://doi.org/10.1016/B978-0-7506-5088-5.X5000-6

Hartinia, S., \& Ciptomulyonob, U. (2015). The relationship between lean and sustainable manufacturing on performance: literature review. Procedia Manufacturing, 4.

Järvenpää, E., \& Lanz, M. (2020). Lean manufacturing and sustainable development. In W. Filho, A. Azul, L. Brandli, P. Özuyar, \& T. Wall (Eds.), Responsible consumption and production. Encyclopedia of the UN Sustainable Development Goals. Cham: Springer.

Johnston, R., Chambers, C., Harland, C., Harrison, A., \& Slack, N. (2002). Zarządzanie działalnościa operacyjna. Analiza przypadków. Warszawa: PWN.

Kadry, S. (2013). Six sigma methodology for the environment sustainable development. In Z. Luo (Eds.), Mechanism design for sustainability. Dordrecht: Springer.

Korhonena, J., Nuurb, C., Feldmannb, A., \& Birkie, S. E. (2018) Circular economy as an essentially contested concept. Journal of Cleaner Production, 175.

Lewicka-Strzałecka, A. (2003). Konsumeryzm kontra konsumeryzm. In Annales. Etyka w życiu gospodarczym, t. 6. Łódź: Salezjańska Wyższa Szkoła Ekonomii i Zarządzania.

Loknath, Y., \& Azeem, B. (2017). Green management-concept and strategies, conference paper. National Conference on Marketing and Sustainable Development. Retrieved December ,2020 from https://www.researchgate.net/publication/330089504

Lowell Centre for Sustainable Production (1998). Sustainable production defined. Retrieved December, 2020 from https://www.uml.edu/Research/Lowell-Center/About/Sustainable-Production-Defined.aspx.

Magraner, R. (2019). Impact of six sigma on sustainability: relationship and framework for their integration. Lund: Lund University.

Manos, A., \& Vincent, C. (2012). The lean handbook: a guide to the bronze certification body of knowledge. Milwaukee: ASQ.

McFarlane, D. A. (2014). The challenges of operations management for business managers. International Journal of Operations and Logistic Management, 3(1).

Modig, N., \& Åhlström, P. (2013). This is lean-resolving the efficiency paradox. Stockholm: Rheologica Publishing.

Mulder, K. (2006). Sustainable development for engineers: A handbook and resource guide. Suffolk: Greenleaf Publishing.

Ohaegbunam, C. (2015). An operations management. Perspective on waste management In a food processing factory. Bachelor's thesis. Tampere University of Applied Science.

Opresnik, D., \& Taisch, M. (2015). The conceptualization of sustainability in operations management. The 22nd CIRP conference on Life Cycle Engineering.

Peng, Y., \& Lin, S. (2008). Local responsiveness pressure, subsidiary resources, green management adoption, and subsidiaries performance: Evidence from Taiwanese manufacturers. Journal of Business Ethics, 79(1/2).

Skibinska, W., \& Kott, I. (2015). Green manufacturing in companies 'policies and activities. The 2015 WEI International Academic Conference Proceedings. Retrieved December, 2020 from https:// www.westeastinstitute.com/wp-content/uploads/2015/04/Wioletta-and-Iga.pdf 
Summary Final Report (1995). Life cycle design-development of methods and guidelines for environmentally sound design of complex products. Integration of environmental considerations into sectoral policies. Retrieved December 2, 2020 from https://cordis.europa.eu/docs/ projects/files

Tennant-Wood, R. (2003). Going for zero: a comparative critical analysis of zero waste events in southern New South Wales. Australasian Journal of Environmental Management, 10(1).

Yusuff, R. B. M., Vahabzadeh, A. H., \& Panjehfouladgaran, H. (2012). Environmental conscious manufacturing for sustainable growth. Conference paper. Conference: International Seminar on Science and Technology Innovation. Retrieved November 5, 2020 from https://www.researchgate. .net/ publication/250002713_Environmental_Conscious_Manufacturing_for_Sustainable_Growth

Wiśniewska, M. (2005). Jak - czyli Kaizen odpowiada na potrzeby. Osiągnięcie efektywnych procesów całej organizacji jest możliwe. Czy Kaizen pozwala osiągnąć ten cel? Zarządzanie Jakością, 1, 24-27.

Womack, J., \& Jones, D. (2003). Lean thinking: banish waste and create wealth in your corporation. New York: Simon \& Schuster.

Zbicinski, I., Stavenuiter, J., Kozlowska, B., \& van de Coevering, H. (2006). Product design and life cycle assessment. Uppsala: The Baltic University Press.

Zero-waste manufacturing (2014). Waste management. Retrieved December, 2020 from https://www. wmsolutions.com /pdf/brochures/ZeroWasteBrochure.pdf

Zych, B. (2013). Myślenie systemowe - podstawowe zasady w pracy coacha. In K. Ramirez-Cyzio (Ed.), Myślenie systemowe w coachingu. Warszawa: Wydawnictwo Pracownia Satysfakcji.

ZWIA-Zero Waste International Alliance (2009). Zero waste definition. Retrieved December 2, 2020 from http://zwia.org/standards/zw-definition/ 



\section{PART 3.}

SUSTAINABLE DEVELOPMENT IN MANAGEMENT 



\title{
1.
}

\section{MARKETING CAMPAIGNS AND SUSTAINABILITYISSUES}

\section{Atanaska Reshetkova}

D. A. Tsenov Academy of Economics

\begin{abstract}
The concept of sustainable development has left its footprints on marketing strategy and, today, it has strong impact on the consumer's mind and behaviour. Globally, consumers are focusing their preferences towards products and brands implementing different innovations to promote sustainability. Marketing managers face the challenge of incorporating the main dimensions of sustainability-environmental, social, and economic, into their strategies. These cases are intended to encourage critical thinking of readers regarding issues related to sustainability marketing strategies and campaigns.
\end{abstract}

Keywords: marketing, retail sector, sustainability. 


\subsection{Love for local brands}

Among the top trends in consumer behaviour in 2020 is the preference for local products and brands (Euromonitor International, 2020, p. 54). People are expressing environmental responsibility through buying from local businesses, and this makes them feel proud of their choice (see Figure 1).

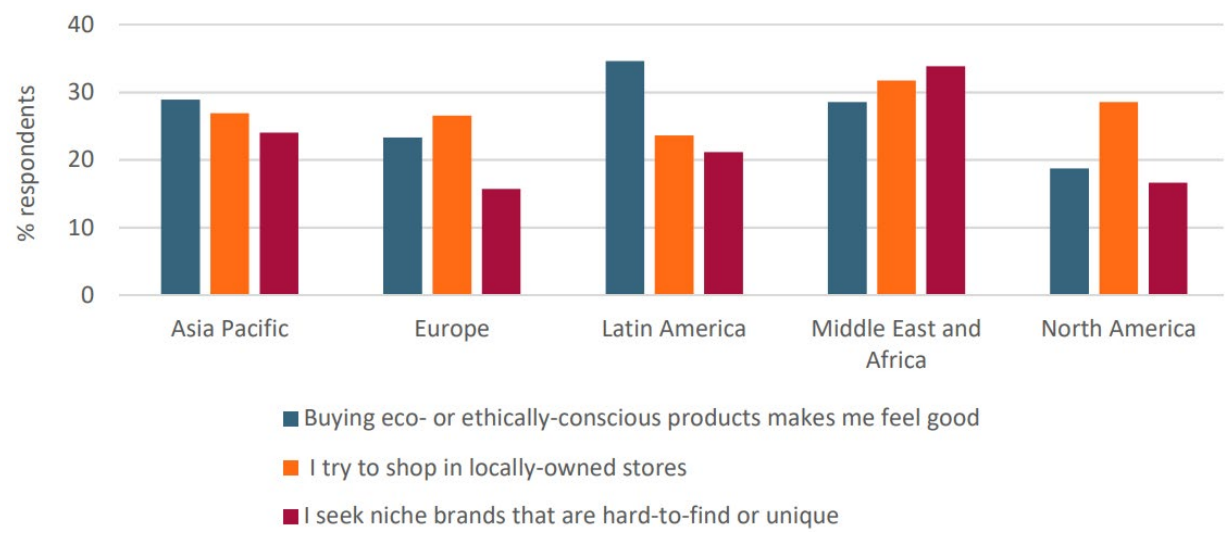

Figure 1. Purchasing priorities by region

Source: (Euromonitor International's Lifestyles Survey, 2019).

\section{Questions / tasks}

1. Describe 3 possible consumer segments on the market of a sustainable product of your choice in terms of socio-demographics, psychological characteristics, and lifestyle of consumers.

2. Give an example from your country (region) of eco-conscious products that are produced and sold in locally-owned stores.

3. Explain the link between the preference for niche brands and unique products and the concept of sustainability marketing.

\subsection{Sustainable fashion: the case of H\&M}

The global fashion giant $H \& M$ was positioned as a fast fashion brand for many years. A number of nature-damaging practices are attributed to fast fashion, such as the use of chemicals and pesticides on cotton, and great amounts of water needed to grow it; the production of greenhouse gases; low wages of workers in factories and bad working conditions. These issues were serious enough to make the Swedish 
company change its strategy to a greener one a decade ago. In 2010, the company launched its H\&M Conscious Collection, which was marketed as being made with sustainable materials-organic, recycled or more durable fabrics. Later, this product line was introduced globally and sold in 54 countries. Today, H\&M is shifting its focus entirely towards sustainable fashion and communicate their new vision on their website (Figure 2).

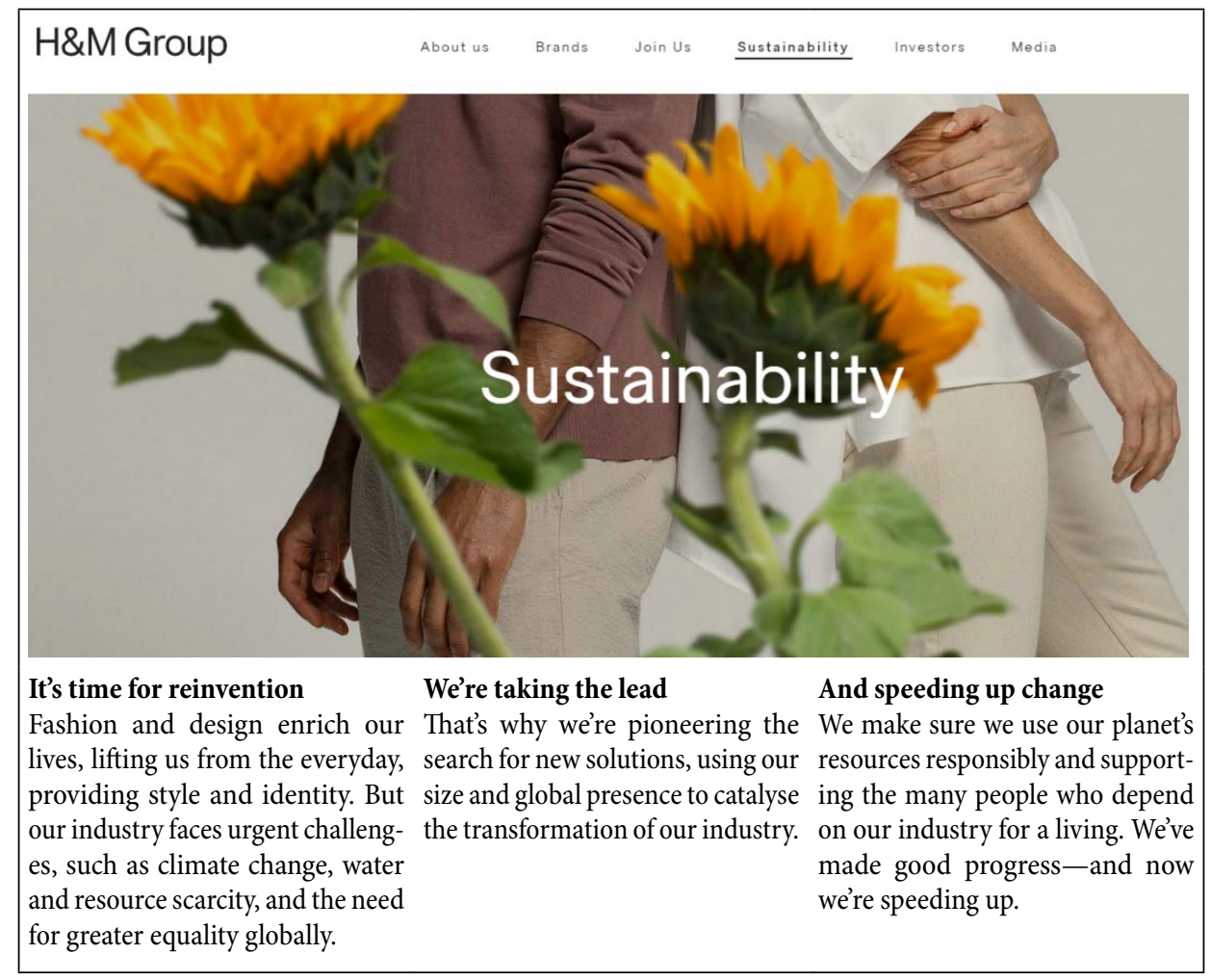

Figure 2. H\&M sustainability statements

Source: (H\&M Group, 2021b).

The company lists the strategic areas describing their intentions:

"Being Fair \& Equal to the people and the communities around us. Using our planet's resources consciously and becoming a Circular \& Climate Positive company. And Leading the Change by pushing ourselves and the industry to reinvent and transform".

- Leading the Change

In 2020, the company was ranked \#1 in the Fashion Revolution 'Fashion Transparency Index' and beat companies such as Adidas, Esprit, The North Face, and many 
others. The company has used artificial intelligence for sustainable decision-making in areas like designing for better resource use and improved forecasting of demand. Relevant information about materials, factories, and suppliers is made public by the company, which increases transparency for customers.

- Fair \& Equal

H\&M's production supply chain has more than 1.1 million workers, for whom the company provides Industrial Relations and Workplace Dialogue Programmes. Topics like diversity and social inclusion are featured in their new training programmes, completed by over 3,600 employees. The company also improved its Wage Management System in order to provide benefits for its workers.

- Circular \& Climate Positive

In 2019, H\&M collected 290,005 tonnes of garments for recycling and reuse, which is equivalent to about 145 million T-shirts. The company started using sustainable materials made from pineapple, algae and citrus. They also offer more sustainable ways for customers to enjoy products, such as repair and rental. The company explored new business models that enable a more circular fashion industry, for example, on-demand, resale and remanufacture.

\section{Questions / tasks}

1. What aspects of sustainable development are addressed by H\&M's sustainability strategy?

2. Read the following press-release and comment on the specific goals for the future and steps already taken by the company in order to implement their sustainable business strategy: https://hmgroup.com/wp-content/uploads/2021/03/ HM-Group-Sustainability-Performance-Report-2020.pdf

For more information visit: https://hmgroup.com/sustainability.html

\subsection{A social experiment to raise consumer awareness}

The global Fashion Revolution movement unites people from the fashion industrydesigners, business leaders, policymakers, brands, retailers, marketers, producers, workers-who work towards "a global fashion industry that conserves and restores the environment and values people over growth and profit". ${ }^{1}$ In 2015, they created a social experiment that featured a vending machine offering $€ 2 \mathrm{~T}$-shirts. But before people could get the T-shirt, they had to watch a video showing the unfair treatment

${ }^{1}$ (Fashion revolution, 2020). 
of workers who made these cheap clothes. Here is how the Fashion Revolution described the experiment and its results2:

"We all like fashion for a bargain but don't often consider how our clothes are made. Fashion Revolution made it their mission to make people aware. We created a simple experiment: would people buy a $€ 2 \mathrm{~T}$-shirt if they knew who really paid the price. $90 \%$ changed their minds and decided to donate, proving people do care when they know. 24 hours after the video was posted we sparked discussion on all big social media channels and it spread around the globe. In just seven days our message went viral reaching over 300 million people in over 200 countries. People flooded the internet with their ideas in the search for a greater solution. Even international celebrities supported our mission. Most importantly, the video was used to speak directly to brands and the brands responded".

\section{Questions / tasks}

1. What sustainability issues do the campaign address?

2. What kind of impact does this experiment pursue?

3. How did marketing help the success of this campaign?

4. Can you think of other industries that can use a similar approach to educate consumers on the negative consequences of their poor product choices?

\section{References}

Euromonitor International. (2020). Top 10 Global Consumer Trends 2020.

Euromonitor International's Lifestyles Survey (2019).

Fashion revolution. (2020). Retrieved from www.fashionrevolution.org/about/

Fashion Transparency Index. (2021). Retrieved from https://www.fashionrevolution.org/about/ transparency/https:/hmgroup.com/wp-content/uploads/2021/04/HM-Annual-Report-2020.pdf H\&M Group. (2021a). Sustainability. Retrieved from https://hmgroup.com/sustainability.html H\&M Group. (2021b). Sustainability performance report 2019. Retrieved from https://sustainabilityreport.hmgroup.com

www.youtube.com/watch?v=KfANs2y_frk

${ }^{2}$ Watch the video at: www.youtube.com/watch?v=KfANs2y_frk/ 



\title{
2.
}

\section{CONSUMPTION AS THE SUBJECT OF MARKET RESEARCH}

\author{
Iwona Olejnik \\ Poznań University of Economics and Business \\ Magdalena Stefańska \\ Poznań University of Economics and Business
}

\begin{abstract}
One of the most important areas of market research is on consumer behaviour and attitudes regarding various aspects of sustainable consumption. Consumer behaviour is understood as activities related to the entire consumption cycle of products from various sectors, which allow the consumer to function and achieve personal goals. They, at the same time, also they allow to achieve satisfaction and well-being, taking short- and long-term effects as well as individual and social consequences into account (Antonides \& van Raaij, 1999).

Within the context of the cited definition, a survey of household rubbish may be very interesting and useful. Such research is not of a declarative nature, but is based on products consumed actually. They can provide extensive information on consumption trends, including, for example, the amount and type of products consumed or food waste. Another example of market research in the context of sustainable consumption is research on products harmful to health, e.g. cigarettes.

The main goal of the chapter is to present 2 unusual examples of market research conducted by various entities: journalists and a research agency. Therefore, the structure of the chapter covers two examples:

1. Garbology as an example of market research in SD-how to learn more about consumers and consumption.

2. Cigarette consumption.
\end{abstract}

Keywords: cigarettes, garbology, market research, sustainable consumption. 


\section{2.l. Is it possible to conduct consumption research on the basis of garbage?}

Garbage tells us a lot about consumption-about consumers, entire societies and even economies. It provides information on household size, age of its members, income, lifestyle, health condition, spending habits, inhabitants' behaviour (if garbage is clean, sorted, how carefully sorted, etc.). ${ }^{1}$

Tannin analysis, which originated in anthropological research, is not yet been a very popular method of conducting marketing research. As W. Pessel points out, in the USA, since the mid-1970s, garbology (from the science of garbage) has been included in archeology (What does garbage say about us, 2020), but it is also similar to sociology.

Rubbish (e.g. of celebrities, households) can be a "subject of research" not only for detectives or economists, but also journalists. An example is research conducted by 2 journalists from the French periodical "Paris Match"-Bruno Mouron and Pascal Rostain. They spent several decades rummaging in the garbage of famous French and Americans and displaying them "on elegant black velvet like expensive jewelry", while, at the same time, making people who view these photos think about their own garbage for even just a moment.

In 2004, they even organised an exhibition in New York for the first time, entitled "Star Trash", selling photos at it for 6,000 dollars apiece. These types of exhibitions are the peculiar result of research on the culture of consumption, enabling a better understanding of society-they show the waste of those whose lifestyle the average American, and not only him/her, wants to imitate. In addition to New York, the photos were shown, among others, in Paris, Moscow, Singapore, Geneva, Taiwan and Miami.

After "researching" celebrity rubbish, in the second phase, journalists began to photograph the garbage of anonymous inhabitants of the world, trying to find out what they want to hide from the world, and calling the project a "photographic studio of globalisation". They carried out their research, i.e., in Qatar, Singapore, China, Russia, Switzerland, France, Malawi, Algeria, Fakarava in Polynesia, Marie-Galante in the Antilles, Japan and Mauritius. They reached out to "average" families and looked at their garbage throughout the week.

Journalists noticed, among others: huge differences in the area of garbage between the rich and the poor. In some countries, especially in poorer ones (e.g. Haiti), there was no paper, packaging or food leftovers in trash cans.

\footnotetext{
${ }^{1}$ Based on the publication: (Rostain \& Mouron, 2021).
} 


\section{Questions / tasks}

1. How can marketing managers use household garbage analysis?

2. How can such methods as IDI, observation, be used in garbage research? Who could use the results of such research?

3. Is the research presented as a case study in the area of SD? What were the goals of companies commissioning such research?

4. What are the limitations/drawbacks of research carried out by Almares? What problems could this agency have had with the research? How else could this type of research be carried out?

\subsection{Consumption of cigarettes as a subject of market research}

There are product categories in sustainable consumption research that are controversial in themselves, such as cigarettes or alcohol. This controversy stems from the fact that the consumption of such products can cause enormous negative social effects-it can lead to many diseases, or even death. Cigarettes, in particular, regardless of the opinion of addicted smokers, are objectively a very controversial product and their production, sale and consumption certainly do not help to achieve goal No. 3 contained in the Agenda for Sustainable Development 2030 (https://www. un.org/sustainabledevelopment/sustainable-development-goals), and that reads: "Ensure healthy lives and promote well-being for all at all ages".

So can cigarette consumption become more sustainable? Smoking cigarettes is a harmful, negatively perceived habit. Can we expect, however, that the tobacco industry will be liquidated for the sake of sustainable development, including health care? Due to the strong lobby of cigarette producers, the job positions they create, and huge tax revenues, this industry is still very strong. On the other hand, many governments have launched regulations obligated manufacturers to finance educational campaigns about the negative effects of smoking. Also, due to growing taxes on cigarettes-they have become more expensive to many users, and owing to that-less accessible. It is expected that both solutions decrease the level of consumption of that products. But since this business is an attractive area for criminal circles, e.g. in the form of cigarette smuggling or tax avoidance, which generates the existence of illegal businesses, often operating on an international scale, still, a huge part of the population smokes cigarettes.

As S. Smyczek (2016) points out, "(...) consumers systematically treat phenomena that were recently considered unfavorable or even pathological more and 
more liberally". It happens that consumers not only fall into excessive shopaholism, but still often buy and consume products that are counterfeit or products from illegal sources, e.g. smuggling or theft. They explain their behaviour, for example, by the fact that thanks to their purchases, someone can feed their family, they compare their "sinful" purchases with the even worse-in their opinion-behaviour of others, e.g. "I buy fake/pirated/stolen products, but big concerns/the state/government want to rob me", indicating that they do it because "everyone does it", or they perceive the company as an organisation large enough that no specific person will suffer from the actions of a single consumer (Fullerton \& Neale, 2011; Vitell, 2003).

Research on cigarette consumption, including the pathological aspects related to them, but also consumer protection, is carried out by various entities. Two examples of research conducted by the Almares research agency commissioned by the National Association of the Tobacco Industry and tobacco concerns as well as by the Polish Consumer Federation are presented below.

\section{Example No. $1^{2}$}

At the request of the National Association of the Tobacco Industry and tobacco concerns, the research company Instytut Doradztwa i Badań Rynku-Almares [Eng. Institute of Consulting and Market Research] conducted a study on the shadow economy regarding the tobacco product market.

The research methodology consisted of random collection from streets and public bins and city sample quotas proportional to the population. The research lasted 1 month, and was carried out by a total 70 cities (40 largest cities and 30 smaller towns), target main samples: 34,000 packs and cigarette waste.

The research allowed to show that in 2011, the shadow market for cigarettes in Poland accounted for $15.4 \%$ of the total tobacco product market (i.e. 8-9 billion cigarettes, $80 \%$ of which came from behind the eastern border, mainly Belarus, Ukraine, Russia). It should be added that most of these types of cigarettes (as much as 43\%) are purchased by the inhabitants of eastern Poland (from the Warmian-Masurian, Podlasie and Lublin provinces). At the end of 2018, the shadow economy of illegal cigarettes in Poland accounted for $11.3 \%$.

\section{Example No. $2^{3}$}

The Consumer Federation conducted a survey on the use of e-cigarettes. The anonymous questionnaire was completed by 1,165 people, including $52.62 \%$ of smokers and $47.38 \%$ of non-smokers. The aim of the study was to create the basis for starting

\footnotetext{
${ }^{2}$ Based on (Poland market survey..., 2011).

${ }^{3}$ Based on (Raport z badania ankietowego... [Eng. Report from a survey study], 2014).
} 
a debate on the legislative regulation of issues related to e-cigarettes, as well as to prepare information and education activities aimed at consumers. Therefore, in the study, the following issues were addressed:

1) the role of e-cigarettes in reducing the negative effects of smoking;

2) the level of consumer knowledge about this type of product;

3) legal regulation of the rules on which e-cigarettes should operate, expected by consumers.

In the research conducted by the Polish Consumer Federation, it has been shown that consumers, among others:

- perceive e-cigarettes as a product similar to traditional tobacco products but, at the same time, such goods may, in the opinion of most of them, be an effective tool to combat addiction to conventional cigarettes;

- have a low level of knowledge about e-cigarettes, and the vast majority have not come across any results of clinical trials on this type of product;

- have doubts about the safety of e-cigarettes and their impact on the functioning of the human body;

- believe that the sale of e-cigarettes should be prohibited for people below the age of 18 ;

- rather support the possibility of extending the prohibitions related to the use of this type of product in public spaces.

\section{Questions / tasks}

1. What are the limitations/drawbacks of the research carried out by the Almares research company? What problems could this agency have had with the research? How else could this type of research be carried out?

2. Evaluate the sample selection in the research conducted by the Polish Consumer Federation. Do you agree with the research results obtained in this area? How can these results be applied in the pursuit of sustainable consumption, including the achievement of Goal 3-"Ensure healthy lives and promote well-being for all at all ages"?

3. Could research on cigarette smoking be carried out among minors? What ethical aspects in conducting such research should then be taken into account? What specific issues could such research concern? Find examples of such research.

4. Discuss whether this theme of research is conducted for achieving SD goals? 


\section{2.}

\section{References}

Antonides, G., \& van Raaij, W. F. (1999). Consumer behaviour: A European perspective. Wiley.

Fullerton S., \& Neale L. (2011). Consumer misbehavior: Does the size of the victimized organization impact the level of disapproval associated with a questionable consumer action? Society for Marketing Advances Proceedings, 25(1).

Poland market survey. Empty discarded pack collection. August-September 2011. Conducted on behalf: British American Tobacco, Imperial Tobacco Group, Japan Tobacco International, Philip Morris International. Retrieved July 12, 2020 from http://www.kspt.org.pl/aktualnosc/Szara-strefa-obrotu-papierosami,7

Raport z badania ankietowego przeprowadzonego przez Federację Konsumentów, dotyczącego wiedzy i opinii konsumentów na temat e-papierosów (2014). Warszawa: Federacja Konsumentów.

Rostain, P., \& Mouron, B. (2013). Les poubelles racontent le monde. Retrieved July 10, 2020 from https:// www.parismatch.com/Culture/Art/Les-poubelles-racontent-le-monde-533816

Smyczek, S. (2016). Determinanty rozwoju patologicznych zachowań konsumentów na rynkach finansowych. Determinants of customers' pathological behaviour in financial markets. Handel Wewnętrzy, 2(361), 364-373.

Vitell, S. J. (2003). Consumer ethics research: Review, synthesis and suggestions for the future. Journal of Business Ethics, 42(1/2).

What does garbage say about us. Retrieved July 2, 2020 from https://www.rp.pl/artykul/334285-Co-mowia-o-nas-smieci.html 


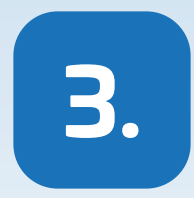

\section{CORPORATE SOCIAL RESPONSIBILITY TOWARDS EMPLOYEES-RABEN GROUP}

Abstract: Human capital management in an organisation is one of the key areas of company success and its competitive advantage, particularly in a service company such as Raben (Zając, 2014).

As an entity operating in the Transport Forwarding Logistics (TFL) sector, its decisions in the area of human resources management depend on industry factors. This is evidenced, among others, by the structure of employees.

The aim of this case study is: first, to draw attention to the problems that companies operating in specific sectors may face. The second goal is to identify their ability to implement the concept of a company responsible to employees. The company strives to take the goals set by the United Nations (SDGs) into account. These include taking care of appropriate employment structure, ensuring employee development, ensuring diversity, caring for work-life balance as well as safety in the workplace, and building relations with external stakeholders. The specificity of the industry in which the presented company operates makes it pursue a number of Sustainable Development Goals-both with regard to employees and in terms of environmental protection. Some need to be adapted accordingly.

Keywords: CSR, employee engagement, employee management. 


\subsection{Raben Group-presentation of the company}

The Raben Group has been operating since the Netherlands since 1931. In Poland, it employs nearly 6,000 people and has approximately 50 depots across the country. It is considered to be a socially-responsible company in both internal (employees) and external environments-confirmed by rankings and competitions: Ranking of Responsible Companies: http://rankingodpowiedzialnychfirm.pl/2020 /06/ranking-odpowiedzialnych-firm-2020-wyniki-klasyfikacja-generalna/. In 2012, Ewald Raben received the E\&Y "Entrepreneur of the Year" Award.

Since 2014, Raben Group has been publishing social reports which include information on socially-responsible activities for the benefit of employees, referring to SD goals. As a result, the report includes, among others, data on training, employment structure by gender, additional activities supporting the idea of work-life balance. The appendix contains Tables 1-8 with information about the structure of employment, training - their number and types, as well as the results of the analysis of Raben Group social reports between 2015-2019.

The company headquarters near Poznan also host regular meetings with external stakeholders. The company carries out dialogues with the local community and tries to satisfy their needs resulting from the conducted activities. These are, for example: restoration of green areas, modernisation of roads or pavements.

\subsection{Tools applied in human resources management by the Raben Group}

The company takes many measures to improve working conditions, its atmosphere and ensure satisfaction of employees. They are presented in Table 1.

Table 1. Tools applied in human resources management by the Raben Group

\begin{tabular}{|l|l|}
\hline Employees & Building interdependent safety culture- "We all care for one another so that everyone is safe". \\
- SUSA discussions - a process of 1:1 discussions in the workplace designed to reinforce \\
safe behaviours; \\
- Safety as part of all operational meetings - safety topics must be a part of all meetings. We \\
believe that talking about safety will allow us to include OHS in all operations and processes; \\
- Safety month-dedicated time to development of work safety through various activities; \\
- Safety teams-top management teams who work for the benefit of building a robust safety \\
culture; \\
- Results (from internal report): \\
- greater engagement in the development of the safety culture, many local actions in this area; \\
- most directors and managers understand their impact on safety at work; \\
- many people believe that accidents can be prevented; \\
- better and more effective communication; \\
- people feel competent and have the equipment they need to perform their tasks.
\end{tabular}




\begin{tabular}{|c|c|}
\hline $\begin{array}{l}\text { Social } \\
\text { programmes }\end{array}$ & $\begin{array}{l}\text { - Social programmes } \\
\text { - The Raben Group also offers employee benefits in the form of: } \\
\text { - private health care; } \\
\text { - group life insurance; } \\
\text { - daily dose of vitamins; } \\
\text { - Multikino cinema tickets; } \\
\text { - fuel discount cards. }\end{array}$ \\
\hline $\begin{array}{l}\text { Health } \\
\text { promotion }\end{array}$ & $\begin{array}{l}\text { Health Week-organised for } 8 \text { years now, during the whole week, meetings with a dietician } \\
\text { and trainers are organised, exercises are planned which are adapted for employees. The aim is } \\
\text { to support employees' health and encourage them to take regular breaks during work, e.g. by } \\
\text { performing exercises that can be done at their desks. During this week, the company develops } \\
\text { a nutritional programme in company canteens. It is worth mentioning that Raben Group } \\
\text { employees enjoy a healthy snack every day as part of their lunch. } \\
\text { Language courses-in addition, for employees who have contact with foreign stakeholders, } \\
\text { we offer subsidised language courses. }\end{array}$ \\
\hline Integration & $\begin{array}{l}\text { Raben on the run-the company participates in sports competitions. In } 2018 \text {, employees } \\
\text { competed remotely in the Endomondo challenge. Seventy participants ran, cycled and walked. } \\
\text { In total, they covered a distance of almost } 100,000 \mathrm{~km} \text { and burned about } 5,000,000 \text { calories. } \\
\text { In addition, they helped the most active employees take the part in various nation-wide runs, } \\
\text { such as: the Color Run, Survival Race and Runmageddon. } \\
\text { Raben Cup-another activity and integration for employees is the Raben Cup. This event } \\
\text { was attended by } 300 \text { athletes, i.e. } 28 \text { teams from } 10 \text { countries. The tournament inspired by the } \\
\text { football cup was organised on } 15 \text { Sep. } 2018 \text { at the MOSiR Stadium in Poznan. The event was } \\
\text { attended by athletes as well as supporters, i.e. families and/or colleagues. Both younger and } \\
\text { older players of both sexes took part in the football tournament. } \\
\text { Events for employees-additionally, Santa Clause days are organised for the children of Raben } \\
\text { Group employees in the form of family picnics aimed at integrating not only employees, but } \\
\text { also their families. }\end{array}$ \\
\hline $\begin{array}{l}\text { Promotion } \\
\text { of diversity }\end{array}$ & $\begin{array}{l}\text { The organisation is a signatory to the Diversity Charter. This means that discriminatory and } \\
\text { unequal behaviour is not accepted, in particular based on age, gender, religion, disability, sexual } \\
\text { orientation, skin colour, marital status, pregnancy, parental status, political opinion, nationality, } \\
\text { ethnic origin, union membership or social status. Discrimination in relation to employee recruit- } \\
\text { ment, access to training, promotions, salaries, dismissals or retirement is also unacceptable. }\end{array}$ \\
\hline $\begin{array}{l}\text { Golden } \\
\text { safety rules }\end{array}$ & $\begin{array}{l}\text { - Golden safety rules applying to all stakeholders of the Raben Group, both internal and } \\
\text { external: } \\
\text { - occupational health and safety; } \\
\text { - equal treatment and counteracting discrimination; } \\
\text { - confidentiality; } \\
\text { - counteracting corruption } \\
\text { - receiving and giving gifts. } \\
\text { As well as the obligations of the Raben Group towards: } \\
\text { - customers; } \\
\text { - suppliers and business partners; } \\
\text { - natural environment; } \\
\text { - local communities; } \\
\text { - the media. }\end{array}$ \\
\hline $\begin{array}{l}\text { Satisfaction } \\
\text { and engage- } \\
\text { ment sur- } \\
\text { veys }\end{array}$ & $\begin{array}{l}\text { Annual employee satisfaction survey } \\
\text { The Pulse Check survey is used to check the level of engagement until the next survey. Ob- } \\
\text { jective-to identify the "pulse" of the organisation and what it has done to build engagement } \\
\text { and whether the actions undertaken so far, are respected by employees. }\end{array}$ \\
\hline
\end{tabular}




\begin{tabular}{|l|l|}
\hline $\begin{array}{l}\text { Counteract- } \\
\text { ing mob- } \\
\text { bing }\end{array}$ & $\begin{array}{l}\text { The whistle-blowing procedure, executed through a confidential tool for reporting } \\
\text { unethical behaviours in the workplace-called Ethics Point-is a guarantee of respect } \\
\text { for the provisions contained in this code. The platform is available in 10 languages. } \\
\text { All employees who report misconduct are protected against all forms of repressive } \\
\text { or retaliatory action arising from the reported misconduct, provided the report is } \\
\text { made in good faith. } \\
\text { Anonymous platform for reporting any abuse or suspicious events-Whistle-blow- } \\
\text { ing-https://polska.raben-group.com/o-nas/odpowiedzialnosc-spoleczna, or directly } \\
\text { to the Audit Department of Raben Group. } \\
\text { Employee engagement surveys which also include questions about mobbing and abuse. }\end{array}$ \\
\hline $\begin{array}{l}\text { Raben } \\
\text { Group } \\
\text { structure }\end{array}$ & $\begin{array}{l}\text { The person responsible for CSR is positioned within the Risk Assessment Department. The } \\
\text { person holding this position reports directly to the Risk Director. His/her responsibilities } \\
\text { include (social area): } \\
- \text { understanding social needs; } \\
- \text { building organisation potential; } \\
- \text { breaking the status quo; } \\
- \text { building relations with subcontractors; } \\
- \text { strategic orientation; } \\
- \text { taking advantage of the opportunities offered by diversity. }\end{array}$ \\
\hline $\begin{array}{l}\text { Training } \\
\text { courses }\end{array}$ & $\begin{array}{l}\text { In the Raben Group, employees can take advantage of both internal and external training } \\
\text { courses. For example, it is possible to learn a foreign language, which is partially financed by } \\
\text { the company. }\end{array}$ \\
\hline
\end{tabular}

Source: Own research.

Concluding, there are many tools to help manage human resources. Companies most often choose those that they can provide and best suit the profile of their business. As far as Raben Group is concerned, the company focuses on the safety of its employees and promotes safe behaviour, not only among employees, but also with regard to suppliers and partners.

\section{Questions / tasks}

1. Why should we care about internal stakeholders?

2. In your opinion, which actions are best to build:

a) employee engagement?

b) trust in the employer?

3. In light of the presented information and additional data, is it possible to assess, on the part of Raben Group in Poland:

a) whether the company has properly selected tools to build employee engagement and trust in the employer?;

b) in your opinion, what other actions the company should take in order to improve its HRM strategy based on the CSR concept?

4. Why is it important to build a culture of diversity in the Raben Group? Justify your answer. 
5. What can the increase in female employment in a TFL company result from?

6. How can the employment of women in the TFL industry affect the industry itself?

7. Do you think that building a safe culture is the right course of action for the benefit of employees?

8. How can TFL companies achieve their sustainability goals?

\section{References}

Raben. (n.d.). Retrieved March 8, 2020 from https://csr.raben-group.com/

Raben Group Reports 2014-2018.

Responsible Business Forum. Retrieved October 24, 2020 from https://valuesdrivenjourney. com/2012/07/15/key-competencies-for-corporate-social-responsibility-csr-roles/http://odpowiedzialnybiznes.pl/wp-content/uploads/2018/08/AnalizaTematyczna_FOB_CSR-owiec-czyli-kto.pdf

Zając, C. (2014). Skuteczne zarządzanie kapitałem ludzkim jako czynnik sukcesu przedsiębiorstwa. Zarzadzanie i Finanse. Journal of Management and Finance, 12(1/2014).

\section{Appendices}

Table 1. Structure of employees in the Raben Group between 2014-2018

\begin{tabular}{|c|c|c|c|c|c|c|}
\hline Year & Females & Dynamics & Males & Dynamics & Total & Dynamics \\
\hline 2014 & 1603 & & 2977 & & 4580 & \\
\hline 2015 & 1677 & $4.61 \%$ & 3105 & $3.60 \%$ & 4782 & $4.41 \%$ \\
\hline 2016 & 1873 & $11.69 \%$ & 3145 & $1.29 \%$ & 5018 & $4.93 \%$ \\
\hline 2017 & 1918 & $2.04 \%$ & 3233 & $2.79 \%$ & 5151 & $2.65 \%$ \\
\hline 2018 & 2007 & $4.64 \%$ & 3287 & $1.67 \%$ & 5294 & $2.77 \%$ \\
\hline
\end{tabular}

Source: (Raben, n.d.).

Table 2. Training course in the Raben Group between 2014-2018 by gender

\begin{tabular}{|c|c|c|c|c|c|c|}
\hline Year & Females & Dynamics & Males & Dynamics & Total & Dynamics \\
\hline 2014 & 2140 & & 2616 & & 4756 & \\
\hline 2015 & 2182 & $1.96 \%$ & 2654 & $1.45 \%$ & 4836 & $2.24 \%$ \\
\hline 2016 & 2602 & $9.24 \%$ & 3040 & $4.54 \%$ & 5642 & $6.66 \%$ \\
\hline 2017 & 2138 & $-17.83 \%$ & 2119 & $-30.29 \%$ & 4257 & $-24.54 \%$ \\
\hline 2018 & 1602 & $-25.07 \%$ & 2026 & $-4.38 \%$ & 3628 & $-14.77 \%$ \\
\hline
\end{tabular}




\section{3.}

Natalia Jankowska

Table 3. Analysis of content of social reports regarding Raben Group between 2014-2018

\begin{tabular}{|l|c|l|c|l|c|l|c|l|c|}
\hline \multicolumn{2}{|c|}{2014} & \multicolumn{2}{c|}{2015} & \multicolumn{2}{c|}{2016} & \multicolumn{2}{c|}{2017} & \multicolumn{2}{c|}{2018} \\
\hline Word: & $\begin{array}{c}\text { Times } \\
\text { word } \\
\text { is used } \\
\text { in text }\end{array}$ & Word: & $\begin{array}{c}\text { Times } \\
\text { word is } \\
\text { used in } \\
\text { text }\end{array}$ & Word: & $\begin{array}{c}\text { Times } \\
\text { word is } \\
\text { used in } \\
\text { text }\end{array}$ & Word: & $\begin{array}{c}\text { Times } \\
\text { word is } \\
\text { used in } \\
\text { text }\end{array}$ & Word: & $\begin{array}{c}\text { Times } \\
\text { word is } \\
\text { used in } \\
\text { text }\end{array}$ \\
\hline employee(s) & 28 & employee(s) & 28 & employee(s) & 48 & employee(s) & 75 & employee(s) & 98 \\
\hline engagement & 2 & engagement & 2 & engagement & 4 & engagement & 5 & engagement & 9 \\
\hline work & 0 & work & 0 & work & 0 & work & 0 & work & 0 \\
\hline employment & 6 & employment & 4 & employment & 8 & employment & 6 & employment & 5 \\
\hline benefit/social & 4 & benefit/social & 4 & benefit/social & 4 & benefit/social & 3 & benefit/social & 8 \\
\hline $\begin{array}{l}\text { work-life } \\
\text { balance }\end{array}$ & 2 & $\begin{array}{l}\text { work-life } \\
\text { balance }\end{array}$ & 2 & $\begin{array}{l}\text { work-life } \\
\text { balance }\end{array}$ & 2 & $\begin{array}{l}\text { work-life } \\
\text { balance }\end{array}$ & 1 & $\begin{array}{l}\text { work-life } \\
\text { balance }\end{array}$ & 3 \\
\hline balance & 0 & balance & 2 & balance & 0 & balance & 1 & balance & 1 \\
\hline health & 2 & health & 6 & health & 4 & health & 10 & health & 10 \\
\hline safety & 10 & safety & 12 & safety & 17 & safety & 21 & safety & 27 \\
\hline
\end{tabular}

Source: Own research based on social reports of the Raben Group (Raben, n.d.). 


\section{4.}

\section{REMOTE WORK AT INTERNATIONAL ENTERPRISES}

Gabriel Grabowski

Contenur Polska Sp. z 0.0 .

Abstract: The aim of the chapter is to initiate discussion on the positive and negative aspects of remote work in Polish branches of international enterprises.

In 3 short case studies presented in the text, situations that made organizations' managements allow their employees work remotely are discussed. In each case, different reasons initiated a decision: plant relocation, hiring a specialist living far from the plant and a threat of pandemic.

There is a common opinion on employees in many countries (including Poland) that they are not flexible enough when searching for a job, they expect it to be "round the corner", whilst it is not only them but also employers that should present a more flexible approach, also in terms of remote working. On the other hand, it must be stressed that such solutions have both advantages and disadvantages and sometimes cannot be available for certain roles in an organisation.

Keywords: pandemic threat, plant relocation, remote work, work-life balance. 


\subsection{Plant relocation}

An international group manufacturing installation equipment with a number of companies in Poland decided to merge 2 of them by moving the smaller one to the bigger one's location. It was decided to optimise production and logistics costs, as well as to let the smaller company operate in a facility belonging to the group instead of renting buildings from a $3^{\text {rd }}$ party at the original location.

Employees of the smaller company (mainly living in surroundings of its first location) were not enthusiastic about the change as the distance to the new factory required over an hour-drive in one direction, which was quite significant. It was obvious that a number of them would decide to leave the organisation because of relocation. To minimise this risk, various benefits were provided in order to encourage people to stay, and some of them were also offered work at the plant 4 days a week and 1 day at home.

The main advantages of the remote work proposal showed people that their work was appreciated by management and, of course, gave them the possibility of smooth transition from working close to home to travelling to work. That was supposed to prevent the organisation from losing key employees. It is obvious that to make that function smoothly, it was extremely important to coordinate homeoffice days in such way that most people would not do that on the same day of the week, but it must be stressed that all team members managed the time schedule very well. This case allows to confirm that the same effects may be obtained when communication is electronically mediated as well as transmitted directly (Kelloway, Barling, Kelley, Comtois, \& Gatien, 2003, p. 169).

One of the disadvantages was that home-office working was available only for some sales or back office employees, whilst it could not be offered to those working in logistics or production. That generated risk of some frustration among those who might have thought they were being treated unfairly. Another weak point was that not only people but also the organisation were in a period of transition (daughter company starting operations at the location of the parent one), and one home office day per week meant $20 \%$ less time to become integrated.

The final result was that despite many efforts, the organisation did not manage to keep all of its valuable employees. Some of them decided to search for work close to home. Nevertheless, many key people stayed at the company or postponed their decision to leave, which also helped to manage the transition smoothly.

\subsection{Hiring a specialist from a different location}

When searching for specialists, many enterprises seem to shift focus too much on candidates' location. They expect their future employees either to live in the neighbourhood or to express the will to relocate to it immediately. At the same time, a potential 
employee that is expected to move his/her whole family to a new place, receives no guarantee that she/he will get the chance to work at the company for a long time.

An international group, operating in the environmental protection business. opened a new plant in Poland. After a few years that were dedicated to introducing products to the Polish market, it became clear that change of sales management was necessary to move the company to next stage in which its position on the market would be strengthened. After a review of commercial managers available in the environmental protection industry, the group's board decided to search for candidates from other branches that could come up with a "thinking outside of the box" approach. Since the group was always focused on candidates' qualifications rather than their location, the person finally chosen lived ca. $500 \mathrm{~km}$ (a 6-h drive in one direction) from the company's office. In order to help that person maintain the best work-life balance possible, the following agreement was reached: each week, the manager would visit his office and some customers, apart from that, he would have the possibility to work from home on some days. Proportions of each of the above-mentioned solutions were not defined, as the employer relied on the manager's maturity.

For the manager, that had already experienced working for far away from home in the past, the biggest advantage was that he could spend the whole weekend (Saturday and Sunday) with his family as usually Monday was his home office day (in the past, when working away from place of residence, he had to start his journey to work on Sunday to be at the office by Monday morning). Apart from that, he could plan home-office work whenever he needed to be at home right after work in the afternoon. An advantage for the enterprise was that the employee, seeing flexibility of his supervisors, was also flexible in terms of his working hours (usually operating longer than was expected). That confirms Felstead's and Henseke's (2017, p. 197) opinion that flexible (e.g. remote) work is a type of working arrangement providing a degree of flexibility on how long, where, when and at what time employees work. A similar opinion has been expressed by Hardill and Green (2003, p. 218), mentioning that by not restricting work to a particular place or time, home-based telework may increase the flexibility of accomplishing work.

No significant disadvantage of such a work model could be identified for the company. The only negative aspect appeared on the end of the employee. His remote working was confusing for his family who was used to the fact that, in the past, when being at home, he usually had time for them. That made the children a bit frustrated when their father was not available until the evening, although he was at home. However, according to recent studies, telecommuting should reduce work-family conflicts by offering job autonomy and flexible scheduling (Mulki, Bardhi, Lassk, \& Nanavaty-Dahl, 2009, p. 65).

Such an approach of the enterprise gave the company a possibility to choose the right manager from a wider group of candidates, whilst the employee could minimise the negative effect of distant work on his/her family life. 


\subsection{Threat of pandemic}

According to estimates, from late 2019. slightly more than $5 \%$ of employees worked remotely on a regular basis. But as COVID-19 spread across the globe in 2020, and shelter-in-place orders were issued by governments, many companies initiated rapid and wholesale shifts to remote work arrangements, at least for knowledge-intensive work (Leonardi, 2020, p. 1). The pandemic threat was experienced by people in many countries. Safety measures and business activity limitations introduced by governments in order to reduce virus transmission affected many businesses. The impact was not that severe for enterprises that could continue their activity devoid of face-to-face meetings with their customers for some time, e.g. those in the B2B sector. Nontheless, such companies needed to change the model of their operations to adjust to new situations. One of main changes introduced by many organisations was remote work that helped reduce the number of people staying in companies' facilities at the same time.

The enterprise that has been described in the previous case study introduced most safety measures relatively quickly, both for production and logistics employees that had to work in the factory (hygienic and protection equipment), as well as for sales and back-office employees. Before any government restrictions were introduced, salesmen were advised to avoid visiting their business partners' facilities that did not seem to be secure from a hygienic point of view. Shortly after that, also back-office employees started working at their homes.

The biggest disadvantage of remote work for the sales team was the fact that they operated in the public sector that required organising purchases by tenders. Luckily, when the pandemic came, electronic public procurement processes had already begun. Thanks to that, managers of the company were equipped with digital signatures and could smoothly manage sales among those customers who organised electronic tenders. However, even some of those customers who had introduced electronic public procurement were not willing to sign contracts in the same way-they expected paper documents, not to mention those not prepared to organise digital tenders at all. In such a case, courier services still appeared to be indispensable.

In the case of back-office employees, the biggest challenge was that most of them were equipped with desktop computers, but this was firstly solved by their good will to use their home appliances and then, the company-bought laptops for all of them. Another disadvantage was the fact that logistics employees did not feel well that they could not work at home although that was partly solved by introducing a kind of shift system that let them stay at the home-office on some days.

The advantage of remote work for employees was the reduction of virus transmission risk (for them and their families), as well as the possibility to take care of their children also staying at home with remote classes. What must be stressed is 
that the enterprise benefitted the most from temporary changes in the working model. Despite its location in one of the most COVID-19 affected areas, no case of infection had been identified at it. The sales team (supported by people in other departments) generated the highest turnover ever as a project in one of the biggest Polish cities had to be managed in the middle of pandemic lockdown. Despite these challenging circumstances, the process went very smoothly.

\section{Questions / tasks}

1. Do you agree with the opinion that employees in many countries (e.g. in Poland) are not flexible enough when searching for a job, that they expect it to be "round the corner", or is it also the enterprises that are not flexible enough to be open to employees living in other parts of the country? What does this situation look like in your country?

2. In the case of a company moving to another location-was it the right decision to let some key employees work partly at home? What other solutions would you propose in such a situation?

3. One of the case studies is about a commercial manager that does part of his work at home. Would it also be possible for the production manager to follow the same pattern?

4. Do you think that the COVID-19 pandemic has influenced the way people will cooperate in the future? Analyse this both from the employer-employee relation point of view as well as from the perspective of business-to-business relations.

5. Imagine you are working at home and need to participate in a video conference call. When you are doing that, your 8-year-old child comes into the room and starts talking to you. Although you try to ignore him/her, the child interrupts you again and several times, always doing the same: talking to you and sometimes even appearing in front of the camera. What do you think the other meeting participants' perception of the situation is?

6. Does a home-office guarantee the best possible work-life balance alone or are there other factors influencing it? What causes children to sometimes fail at understanding that, although their mother/father spends more time at home than before, she/he cannot be available for them whenever they want?

\section{References}

Felstead, A., \& Henseke, G. (2017). Assessing the growth of remote working and its consequences for effort, well-being and work-life balance. New Technology, Work and Employment, 32(3), 195-212. Hardill, I., \& Green, A. (2003). Remote working-altering the spatial contours of work and home in the new economy. New Technology, Work and Employment, 18(3), 212-222. 


\section{4.}

Gabriel Grabowski

Kelloway, E. K., Barling, J., Kelley, E., Comtois, J., \& Gatien, B. (2003). Remote transformational leadership. Leadership \& Organization Development Journal, 24(3), 163-171.

Leonardi, P. M. (2020). COVID-19 and the new technologies of organizing: Digital exhaust, digital footprints, and artificial intelligence in the wake of remote work. Journal of Management Studies, 58(1), 1-5.

Mulki, M., Bardhi, F., Lassk, F., \& Nanavaty-Dahl, J. (2009). Set up remote workers to thrive. MITSloan Management Review, 51(1), 63-69. 


\title{
5.
}

\section{PRODUCT LIFE-CYCLE-PROBLEMS OF PRODUCT PLANNED OBSOLESCENCE AND FAST FASHION}

\author{
Magdalena Stefańska \\ Poznań University of Economics and Business
}

\begin{abstract}
Corporate Social Responsibility (CSR) is an idea according to which enterprises take responsibility for the effects of their activities and undertake actions aimed at reducing negative effects and improving quality of life of a broadly understood group of stakeholders. In turn, marketing is a concept according to which all activities of enterprises are undertaken with the intention of satisfying consumer needs in the best possible way-by creating and modifying products and services.

It would seem that they both-CSR and marketing, share the same goal-providing value to consumers in order to improve their quality of life. However, it can be seen that there is a whole scope of activities under the marketing instruments that primarily serve only to intensify sales. This would not raise any major objections if not for the fact that the occurrence of the demand for restitution is accelerated due to the planned shortening of the product life-cycle. This is in contradiction with the idea of CSR and sustainable development as well as sustainable consumption. So why is it a practice that does not cause widespread outrage and resistance from buyers? And how should it be dealt with?

Two widely implemented strategies of manufacturers and retailers are described in that chapter: the $1^{\text {st }}$ one is planned product obsolescence, the second-fast fashion. Retail chains follow the fast fashion trend-offering customers short, frequently changing product lines.

However, seeing the effects of this type of strategies, it is possible to undertake a number of activities aimed at reducing the negative effects of these actions.
\end{abstract}

Keywords: fast fashion, greenwashing, planned product obsolescence, product life cycle, sustainability. 


\subsection{Planned product obsolescence-how to overcome the problem?}

The deliberate shortening of the product life-cycle appeared in the $1^{\text {st }}$ decades of the $20^{\text {th }}$ century, including saturating the market with some products. This phenomenon was observed, among others, in the automotive industry, and consisted in launching changes to vehicles in order to stimulate the demand for new models (re-styling). The term was also used in the context of incandescent lamps that were designed to last 2,000 hours-meanwhile, manufacturers agreed and began to produce incandescent lamps that work for half the time (Krajewski, 2014).

According to the definition from 1977, planned product obsolescence means to accelerate the replacement and renewal needs of consumers by a planned reduction of consumer goods' operating life in order to support growth opportunities for a business (Hillmann, 1977; Schallmo, Brecht, Heilig, Kauffeldt, \& Welz, 2012). Furthermore, in another definition by Guiltinan (2009), it is stated that the objective of planned obsolescence is to stimulate replacement buying by consumers. This is often achieved through frequent design changes, using nondurable materials, terminating the manufacture and availability of replacement parts as well as introducing a superior model of the product. According to Bulow (1986), "planned obsolescence" is the production of goods with uneconomically short useful lives so that customers will have to make repeat purchases. However, rational customers will pay for only the present value of the future services of a product.

Shortening life-cycle can be achieved by weakening the most vulnerable parts of a construction or using low-quality materials for production. Another trap is connected with sensitivity to certain conditions, while the use of the product, e.g. sensitivity to higher temperatures than ambient, susceptible to shocks or vibrations, not resistant to moisture, etc. Below, examples of techniques used in many industries to purposefully shorten product life-cycle can be found.

An extreme case of shortening the life-cycle is the production of single-use devices, e.g. cameras, which after taking pictures are not fit for use.

Another example of purposefully shortening the product life-cycle may be to create a product which wears out faster than it could work with other components, and as a result, it requires replacement, but the cost of operation and parts usually exceeds the desirability of doing so. It is usually decided early in the design of a complex product stage-how long it is designed to last so that each component can be made to those specifications. And since it is impossible for any designed object to retain its function forever; the whole products will ultimately break down, no matter what steps are taken, or they will require extremely high costs of repair. The durability is contrived by designers to secure financial plans of product profitability.

Planned obsolescence also occurs when it is decided early in the design of a complex product how long some parts of this product are designed to last or 
work. Such products are often designed to be impossible to service. In such tactics, manufacturers may not secure replacement parts-and since they are unavailable or so expensive-it makes the product uneconomic to repair.

Non-replaceable batteries by the end-user after they have worn down is also an example of compulsory replacement of the product or the use of a service that increases costs for the user. The creation of laptops or mobile phones with integrated batteries has causes the shortened life-cycle of this type of equipment-making replacement a requirement. Some models of smartphones are designed so that replacing the battery is very difficult for the final user (because doing so might cause irreparable damage to the main board of the phone). The only solution for consumers is to send it off to be repaired by a professional repair service provider or by the manufacturer or... to buy a new phone (Finance reference, n.d.).

A further example of planned obsolescence is connected with fashion and frequent modification in design. Obsolescence of desirability or stylistic obsolescence occurs when designers change the design of products so customers will purchase them more frequently due to the decrease in the perceived desirability of unfashionable items. This is especially noticeable in the car industry, where after 1 or 2 years after releasing a new car model, some very soft changes in design are made (but visible outside the car), so for fun-users who like the newest models, it us a signal that they need to make a change to the refreshed model.

Also, in some cases, creating new-upgraded software-requires new hardware. As a result, this can also shorten the product life-cycle. Otherwise, it become unserviceable.

The lifetime of products can be extended at the design stage and while creating and getting to know the weak elements of the structure, followed by their strengthening. This can also be done by applying innovative solutions. And since on mature markets the phenomenon of planned obsolescence exists, organisations try to find solutions to continue their growth and, at the same time, not necessary by reducing the lifespan of the products sold

For example, the idea of sustainability can be interpreted in the context of the software life cycle as (Singh \& Sandborn, 2006):

a) maintaining an existing system operational (the ability to successfully complete its intended purpose);

b) continuation to manufacture and field versions of the system that satisfy the original requirements;

c) manufacturing and field revised versions of the system that satisfy evolving requirements.

Another interesting strategy is piggy-backing. It enables renewed functionality of a technologically obsolete product. This is achieved through the integration or add-on of a secondary devise or component. Not to be confused with upgrading strategies, piggy-backing requires a device that fits adjacent to, upon, or within 
the existing product's (parent product) architecture. Piggybacking is an attractive strategy for consumer electronic products that are particularly prone to technological obsolescence, as it offers a means to accommodate fast and slower changing technologies within a product (Rai \& Terpenny, 2007).

To conclude, the causes of this phenomenon should be seen both on the part of the enterprises and consumers who decide to buy products despite "not using up the previous one". The phenomenon of planned obsolescence has both its pros and cons-for some manufacturers-it is not a deliberate shortening of the life-cycle, but a natural process of technical progress and innovation. It is also an element of building prosperity and ensuring economic growth, as well as meeting the customer needs with innovative products that are more economical in many respects, more efficient and effective. And, in fact, manufacturers just react to consumer demand, no matter whether it is created through a real need or as a result of effective marketing. For others-it is unnecessary to buy new products that are not completely used up in a technical sense. This leads to littering the environment and what is more, the newly produced ones contribute to the devastation of the natural environment. How do we escape that trap?

\section{Questions / tasks}

1. Define planned product obsolescence.

2. Give examples for each type of planned product obsolescence.

3. What is the relationship between planned product obsolescence and product innovations, if any?

4. What are the side-effects of planned product obsolescence for the whole added value chain?

5. Should planned product obsolescence be legally forbidden?

6. How could consumers influence manufacturers to not practice planned product obsolescence?

7. What is your opinion of solutions implemented in the case of software? Do you see any limitations in such solutions? What are your propositions?

\subsection{Fast fashion-on the way to sustainability or... greenwashing?}

The clothing industry has greatly changed over the last few decades. First of all, the number of fashion seasons has increased significantly, which prompts consumers to buy clothes or footwear more frequently. Since consumer income does not grow fast enough for the changing supply, clothing must be decidedly more inexpensive, 
which is ensured by producing clothing in cheap labour countries and shortening the life-cycle of products. As a result, consumers can adapt to the promoted fashion trends several times a year. However, this phenomenon leads, apart from the positive phenomena-in the form of job creation in manufacturing countries-to negative effects-in the form of destruction of the natural environment, increasing the amount of waste and violation of human and workers' rights.

"Fast fashion" is a term used to describe a new accelerated fashion business model that has evolved since the 1980s. It involves increased numbers of new fashion collections every year, quick turnarounds and often lower prices. Reacting rapidly to offer new products to meet consumer demand is crucial to this business model (Fixing fashion: clothing consumption and sustainability, 2019).

Sustainable consumption is an idea according to which consumers guide their purchasing and consumer decisions in such a way that they do not expose future generations to deterioration in their quality of life. It consists, inter alia, of consciously making purchases and limiting consumption if it has negative consequences for future generations, e.g. due to the production of large amounts of waste, consumption of water or energy. Examples of consumer behaviours which fall within the scope of sustainable consumption include: the recycling of household waste, purchase of 'sustainable' products, using energy-efficient appliances, choosing green electricity tariffs, composting garden and kitchen waste, investing in 'ethical' funds, conserving water or energy, buying organic food, returning electrical goods for re-use or recycling, switching transport mode, changing travel behaviours, buying remanufactured or reused goods, reducing material consumption, pursuing 'voluntary simplicity', and so on (Jackson, 2005).

The phenomenon observed in the clothing industry allows to indicate different consumer behaviours-they favour the policy applied by global retail chains, abbreviated as "fast fashion".

In the second half of the $20^{\text {th }}$ century, retailers developed a business model in which the production of clothes, due to low labour costs, takes place in overseas countries-Bangladesh, India, Pakistan, Vietnam, Cambodia, Indonesia or China, while their sale-occurs in Europe or the USA. This model is used by global networks, thus, effectively separating the location of production from the place of consumption. The interest of retailers in acquiring cheap sources of production has significantly changed the economy of countries in which production has been commissioned. For example, in Bangladesh, over 5,500 jobs were created after 1990 at factories employing nearly 4 million people. In 2019, there were about 4,620 garment factories in Bangladesh. Although this increased compared to the previous year, this was a decrease in contrast to 2013, in which there were approximately 5,880 garment factories in Bangladesh. In 2019, the export value of ready-made garments (RMG) in Bangladesh amounted to approximately just over 34 billion U.S. dollars and roughly $80 \%$ of the country's export earnings came from clothing 
sales abroad, with global retailers such as H\&M, Primark, Walmart, Tesco and Aldi among the main buyers (Statista, 2021).

Bangladesh is the $2^{\text {nd }}$ largest clothing manufacturing market in Asia after China. The minimum monthly salary of employees is about $\$ 95$, which is similar in Myanmar, and less only in Ethiopia (compared to over \$300 in China). Due to the working conditions at sewing factories, sometimes called "sweatshops", safety standards are very low, the conditions difficult to work in, while the rights of children and workers are not respected and the employees are subject to discrimination. A fire in 2012 at a production plant for Walmart in Dhaka, which killed 117 people, and a few months later, in 2013, the collapse of a building containing factories sewing clothes for European and American clothing chains (Rana Plaza), also in Dhaka-1,136 people died there-made the media return to the topic of inhumane conditions for the production of clothes that Europeans and Americans buy in retail chains. The industry is also facing a problem regarding the lack of qualified middle-management. Anxiety is further caused by the automation of production processes.

'Fast fashion' is a term used to describe a new accelerated fashion business model that has evolved since the 1980s. It involves increased numbers of new fashion collections every year, quick turnarounds and often lower prices. Reacting rapidly to offer new products to meet consumer demand is crucial in this business model. In accordance with the model, clothing should be replaced with new products several times a year, while old, even undamaged garments or shoes, should be discarded. Fast fashion is a "disposable" fashion, for immediate- and short-term consumption. Clothing is designed to be used for 1-2 months, thrown away and buying something new with the appearance of a new collection. New fashion seasons are imposed, as a result of which, instead of the classic periods of changing clothes lines, i.e. spring/summer and autumn/winter, additional-preceding and closing periods with very intensive promotion, are introduced. In the literature, this trend is described, among others, within the context of changes in retail business models (Sempruch-Krzemińska, 2014) or consumer attitudes (Wanat, 2016).

Fast fashion is in conflict with the idea of sustainable consumption-it does not make consumers think about the impact of increased purchase or consumption frequency on the natural environment and living conditions in both countries of production and consumption.

This business model encourages over-consumption and generates excessive waste. It hurts-again - both the countries of production and consumption.

Pressure from consumer and human rights organisations has had impact on clothing retailers to make sure products from their stores do not raise concerns about the conditions in which they are produced. Enterprises have taken steps to tighten the criteria for selecting suppliers. A number of non-profit organisations, associating retailers and producers, have been established to ensure respect for human rights, environmental protection and implementation of SD goals (Table 1). 


\section{Table 1. NGOs engaged in the textile industry-examples}

\begin{tabular}{|c|c|}
\hline Organisation (NGOs) & Members-examples ${ }^{\star}$ \\
\hline $\begin{array}{l}\text { Action, Collaboration, Transformation } \\
\text { Since 2016, } 21 \text { retailers have signed the Memorandum } \\
\text { of Understanding (MoU), a framework which outlines } \\
\text { actions to establish freedom of association, collective } \\
\text { bargaining and living wages within global supply chains. } \\
\text { https://actonlivingwages.com/who-we-are/ }\end{array}$ & $\begin{array}{l}\text { Members: } \\
\text { C\&A, H\&M, Lidl, Tesco, Inditex, Espirit, Next, } \\
\text { New Look, Tchibo, Zalando Vero Moda, Wallis, } \\
\text { Target, Zara, Bershka, Stradivarius, Uterque, Zara } \\
\text { Home, Massimo Dutti }\end{array}$ \\
\hline $\begin{array}{l}\text { Better Cotton Initiative, BCI } \\
\text { BCI aims to do this by reducing the environmental im- } \\
\text { pact of cotton production, improving livelihoods and } \\
\text { economic development in cotton producing areas, and } \\
\text { securing commitments to Better Cotton throughout the } \\
\text { supply chain. } \\
\text { https://bettercotton.org/ }\end{array}$ & $\begin{array}{l}\text { Members (all: 1992). } \\
\text { Among retailers: Adidas, Zeeman, Marqet, Ralph } \\
\text { Lauren, Nike, John Lewis, Kmart, Kohl's, S'Oliwer, } \\
\text { Tesco, Splash, Marimekko, Brothers, House of An- } \\
\text { ita Dongre, Z8, Tommy Hilfiger, Zalando } \\
\end{array}$ \\
\hline $\begin{array}{l}\text { Ethical Trading Initiatives, ETI } \\
\text { The Ethical Trading Initiative (ETI) is a leading alliance } \\
\text { of companies, trade unions and NGOs that promotes } \\
\text { respect for workers' rights around the globe. Compa- } \\
\text { nies with a commitment to ethical trade adopt a code } \\
\text { of labour practice that they expect all their suppliers } \\
\text { to work towards. Such codes address issues like wages, } \\
\text { hours of work, health and safety and the right to join } \\
\text { free trade unions. } \\
\text { https://www.ethicaltrade.org/about-eti }\end{array}$ & $\begin{array}{l}\text { Members: } \\
\text { Aldi, Alsico, Apetito, ASDA, ASOS, Bidfresh, Bon- } \\
\text { marche, Burberry, C\&A, Clarks, Co-operative Re- } \\
\text { tail, Commercial Group, Ethical Apparel Africa } \\
\text { Association, Gap, H\&M, Inditex, Jack Wills Ltd, } \\
\text { KappAhl, Marks\&Spencer, Marshalls, Matrix APA, } \\
\text { Missguided, Morrisons, Mothercare, Mr Price, } \\
\text { New Look, Next, Orsay, Oxfam, Partner Africa, } \\
\text { Primark (ABF Limited), J Sainsbury plc, Tesco, } \\
\text { The Body Shop International, The Fair Trade Foun- } \\
\text { dation, Unicef }\end{array}$ \\
\hline $\begin{array}{l}\text { Make Fashion Circular } \\
\text { This aim is to stimulate the level of collaboration and } \\
\text { innovation necessary to create a new textiles economy, } \\
\text { aligned with the principles of circular economy. The vi- } \\
\text { sion is to eliminate the negative consequences of the } \\
\text { current extractive operating models and move towards } \\
\text { regenerative ones demands people to rethink every as- } \\
\text { pect of our working practices, their scale and pace. It } \\
\text { ensures that products (apparel, footwear, accessories) } \\
\text { are used more made to be made again, made from safe } \\
\text { and recycled or renewable inputs. } \\
\text { https://www.ellenmacarthurfoundation.org/our-work/ } \\
\text { activities/make-fashion-circular }\end{array}$ & $\begin{array}{l}\text { Members: } \\
\text { Burberry, Gap Inc., H\&M Group, HSBC, Inditex, } \\
\text { PVH and Stella McCartney as Core Partners. } \\
\text { The initiative brings leaders together from across } \\
\text { the fashion industry, including brands, cities, phi- } \\
\text { lanthropists, NGOs, and innovators }\end{array}$ \\
\hline $\begin{array}{l}\text { Microfibre Consortium } \\
\text { The Microfibre Consortium (TMC) facilitates the devel- } \\
\text { opment of practical solutions for the textile industry to } \\
\text { minimise fibre fragmentation and release to the envi- } \\
\text { ronment from textile manufacturing and product life- } \\
\text { cycle. The organisation presents the opportunity to align } \\
\text { globally as an industry through its connection through } \\
\text { its member base at the brand, retail, supplier, research, } \\
\text { industry organisation and policy level. } \\
\text { https://www.microfibreconsortium.com/about/ }\end{array}$ & $\begin{array}{l}\text { Members: } \\
\text { Adidas, Helly Hansen, M\&S, Primark, Asda, } \\
\text { boohoo, Decathlon, H\&M Group, Inditex, Home } \\
\text { Sense, Jack Wolfskin, John Lewis \&Partners, Lulu- } \\
\text { lemon, Mamut, Morrisons, Next, Nike, The North } \\
\text { Face, Patagonia, Pentland, Puma, Repreve, Target } \\
\text { Tchibo, TK Maxx }\end{array}$ \\
\hline
\end{tabular}




\begin{tabular}{|c|c|}
\hline Organisation (NGOs) & Members-examples* \\
\hline $\begin{array}{l}\text { Sustainable Apparel Coalition } \\
\text { The Sustainable Apparel Coalition is the apparel, foot- } \\
\text { wear and textile industry's leading alliance for sustain- } \\
\text { able production. Over } 250 \text { members: retailers and manu- } \\
\text { facturers. } \\
\text { https://apparelcoalition.org/ }\end{array}$ & $\begin{array}{l}\text { Members: } \\
\text { Abercombie\&Fitch, Amazon, Amer Sport, United } \\
\text { Colors of Benetton, Bestseller, boohoo, Brooks } \\
\text { C\&A, Camper, Patagonia, Carter's, Disney, Fjall- } \\
\text { raven, Gap Inc, Guess, H\&M Group, Inditex, J. } \\
\text { Crew, JC Penney, KappAhl, Kathmandu, Kering, } \\
\text { Kohl's, Levis, Lululemon, Macy's, Mamut, Mango, } \\
\text { M\&S, New Look, Nike, Nordstrom, Orsay OVS, } \\
\text { Primark, Puma, Ralph Lauren, Target, Tesco, } \\
\text { Walmart, Zalando }\end{array}$ \\
\hline $\begin{array}{l}\text { Textile Exchange } \\
\text { It inspires and equips people to accelerate sustainable } \\
\text { practices in the textile value chain. We focus on minimis- } \\
\text { ing the harmful impact of the global textile industry and } \\
\text { maximising its positive effects. Goals: embedding sus- } \\
\text { tainability into evolving business and supply chain strate- } \\
\text { gies, making it easier for companies to adapt to changing } \\
\text { opportunities and requirements in textile sustainability, } \\
\text { ensuring that actions taken towards sustainability result } \\
\text { in real and meaningful change. } \\
\text { https://textileexchange.org/about-us/ }\end{array}$ & $\begin{array}{l}\text { Members: } \\
\text { 3M, Amazon, Textile Exchange, Balenciaga, Best- } \\
\text { seller, United Colors of Benetton, Bellandi, Better } \\
\text { Cotton Initiative, C\&A, Esprit, Gap, Fjal Raven, } \\
\text { Guess Inc, H\&M Group, Gucci, IKEA, Inditexm, } \\
\text { John Lewis, J. Crew, KappAhl, Kathmandu, La- } \\
\text { coste, Kering, M\&S, LVMH, Mayamiko, NB, Pri- } \\
\text { mark, Tchibo, Vans, Walmart, Zalando, Wrangler }\end{array}$ \\
\hline
\end{tabular}

${ }^{*}$ Full list of members available on NGO websites.

Source: Own work based on websites.

Factory supervision programmes have been developed, salaries as well as work safety standards raised, and the supplier monitoring system intensified. The factories that did not pass the inspection were either closed or cooperation with them was terminated. However, the number of contractors with whom global trading companies cooperate is so large that it is not always possible to ensure standards are consistent with CSR.

Other activities addressed to consumers include, among others: encouraging customers to return used clothes and buy new ones with discounts, providing information on using ecological cotton, sustainable sources or recycled materials for the production of new clothes, promoting social and ecological programmes implemented by companies and inviting their clients to participate in them (Stefańska \& Pilarczyk, 2015). Some companies introduce product lines that were created as a result of recycling. In addition, they provide innovative solutions in the area of logistics, use renewable energy sources, and in the case of factories at which sewing is commissioned - they increase production supervision (Stefańska \& Śmigielska, 2016). They disclose information about their activities in reports on their websites, also at the point of sale-on displays or product labels.

With the above initiatives, retail chains are trying to fit into the sustainable development trend, adhering to the fast fashion business model. They undertake 
a number of activities to emphasize their commitment to the implementation of the 3P model, taking responsibility for their business. However, the concept of 3P, i.e. People-Planet-Profit or 5P (People-Planet-Prosperity-Peace-Partnership), becomes very difficult to implement by retailers offering clothing, and even more difficult to advertise, because communication messages would have to confirm the pursuit of social and socio-ecological goals, without limiting the pursuit of economic goals expected by shareholders.

\section{Questions / tasks}

1. Consumer hypocrisy - fast fashion and sustainable consumption-all in one?

2. What is greenwashing?

3. Sustainable consumers and fast fashion-the perspective of global retailersgreenwashing or really good will?

4. As a manager of a retail company - what would you recommend to do to push the company in a more sustainable direction?

\section{References}

Bulow, J. (1986). An economic theory of planned obsolescence. The Quarterly Journal of Economics. Oxford University Press, 101(4), 729-749. https://doi.org/10.2307/1884176

Finance reference. (n.d.). Planned obsolescence. Retrieved from https://www.financereference.com/ learn/planned-obsolescence

Fixing fashion: clothing consumption and sustainability. (2019). Sixteenth Report of Session 2017-19 ordered by the House of Commons. Retrieved November 17, 2020 from https://publications. parliament.uk/pa/cm201719/cmselect/cmenvaud/1952/1952.pdf

Guiltinan, J. (2009). Creative destruction and destructive creations: Environmental ethics and planned obsolescence. Journal of Business Ethics, 89, 19-28. Retrieved November 17, 2020 from http:// www.jstor.org/stable/40295074

Hillmann, K.-H. (1977). Geplante Obsoleszenz, Bemerkungen zu Burkhardt Röper: gibt es geplanten Verschleiß?, Zeitschrift für Verbraucherpolitik, 1(1), 12-65.

Jackson, T. (2005). Motivating sustainable consumption - a review of evidence on consumer behaviour and behavioural change. Report by Centre for Environmental Strategy. Retrieved November 17, 2020 from https://www.researchgate.net/publication/275638627_Motivating_Sustainable_ Consumption_A_Review_of_Evidence_on_Consumer_Behaviour_and_Behavioural_Change

Krajewski, M. (2014). The Phoebus cartel engineered a shorter-lived lightbulb and gave birth to planned obsolescence. Retrieved November 17, 2020 from https://spectrum.ieee.org/tech-history/dawn-of-electronics/the-great-lightbulb-conspiracy

Rai, R., \& Terpenny, J. (2007). Principles for managing technological product obsolescence. International Conference on Engineering Design, Iced'07. Retrieved November 17, 2020 from https:// www.designsociety.org/publication/25403/Principles+for+Managing+Technological+Product +Obsolescence 


\section{5.}

Magdalena Stefańska

Schallmo, D. R. A., Brecht, L., Heilig, I., Kauffeldt, J. V., \& Welz, K. (2018). Clarifying obsolescence: Definition, types, examples and decision tool, July 2012. Conference: 5th ISPIM Innovation Symposium "Stimulating Innovation: Challenges for Management, Science \& Technology". December 9, 2012, Seoul.

Sempruch-Krzemińska, K. (2014). Proces zakupu odzieży fast fashion. Marketing i Rynek, 3, 18-24. Singh, P., \& Sandborn, P. (2006). Obsolescence driven design refresh planning for sustainment-dominated systems. The Engineering Economist, 51(2), 115-139.

Statista. (2021). Number of garment factories in Bangladesh from 2010 to 2019. Retrieved from https:// www.statista.com/statistics/987697/bangladesh-number-garment-factories/

Stefańska, M., \& Pilarczyk, B. (2015). Strategiczne i operacyjne znaczenie CRM. Cause Related Marketing w strategii przedsiębiorstw handlowych. Marketing i Rynek, 8, 690-698.

Stefańska, M., \& Śmigielska, G. (2016). Nowe wyzwania dla handlu detalicznego i marketingu zrównoważona konsumpcja a innowacje przedsiębiorstw handlowych. Zeszyty Naukowe SGGW, Polityki Europejskie, Finanse i Marketing, 16(65), 79-87. Retrieved from https://pefim.sggw.pl/ article/view/4654/4174

Wanat, T. (2016). Wpływ ceny i asortymentu na częstotliwość wizyt w sklepach typu fast fashion. In M. Sławińska (Ed.), Handel we współczesnej gospodarce. Nowe wyzwania. Wydawnictwo Uniwersytetu Ekonomicznego w Poznaniu. 


\section{PART 4.}

\section{SUSTAINABILITY}

AND SUSTAINABLE DEVELOPMENT-SECTORAL PERSPECTIVE 



\title{
1.
}

\section{SOCIAL RESPONSIBILITY AND QUALITY IN PRACTICE}

\section{Krisztián Kis}

Faculty of Engineering, University of Szeged

\begin{abstract}
In this chapter, two excellent examples from Hungary are presented as cases related to the issues discussed in Chapter 2.6, titled Social responsibility and quality: issues of competitiveness and sustainable development. One case is about a Sustainable restaurant initiative introduced by the Heroes of Responsible Dining Foundation, while the other concerns the Safe place certification developed by the CertUnion certification and consulting company. Both cases are examples for presenting responsibility, quality and innovation from different approaches while contributing to both competitiveness and sustainable development.
\end{abstract}

Keywords: certification, commitment, confidence, consumer awareness, dining, hygiene, responsibility, sustainability criteria. 


\subsection{Sustainable restaurant initiative ${ }^{1}$}

The Heroes of Responsible Dining Foundation is aiming towards the creation of a new kind of dialogue on food and to translate Sustainable Development Goals into understandable, everyday actions. The Foundation's objective is to make environmentally conscious, responsible eating as widely-known as possible. In this context, the Foundation experts present, within the framework of a wide range of professional and educational activities, what individuals and catering facilities can do to ensure that environmental considerations prevail during meals. In recent years, much information and various awareness-raising campaigns have been launched, in which not only information was the main aspect, but also, active participation of the population was encouraged, and their Responsible Restaurant network already has more than 50 members.

\section{About the Heroes of Responsible Dining Foundation}

The Foundation aims to spread environmentally conscious, responsible dining and to help the environmental efforts of Hungarian restaurants. In order to reach this goal, raising public awareness concerning the environmental effects of food consumption is needed. The Foundation encourages individuals to choose local and seasonal products, consume less meat and dairy products, and to reduce their food waste. To promote these behaviours and outcomes, the Foundation launches interesting challenges and inspiring campaigns, further offering team-building programmes and educational activities for students. Since its foundation in 2012, the Heroes of Responsible Dining Foundation has won numerous awards and motivated millions of people to eat more responsibly. It has also developed a certification system that recognises green restaurants and encourages the participants in the food-service industry to invest in environmentally-friendly solutions.

\section{About the sustainable restaurant initiative}

The Heroes of Responsible Dining Foundation is the first and only organisation in the country that qualifies restaurants on the basis of sustainability criteria, which, if they meet the 7 key criteria, can receive the Sustainable Restaurant certificate (Papp \& Lugasi, 2018).The certification issued by the Heroes of Responsible Dining Foundation can be obtained by restaurants and catering companies that are con-

${ }^{1}$ This subchapter is based on information available from the following websites: https://gasztrohos. hu/vedjegy/fenntarthato-vendeglatohely; https://www.gasztrohos.hu/fenntarthato-vendeglatohelyminosites; https://www.gasztrohos.hu/en. 
stantly working to reduce the ecological footprint associated with their operations. The Foundation's experts help qualified restaurants benefit from their efforts, for example, through media appearances and participation in international projects, while optimising waste management, energy and water efficiency as well as raw material sourcing, etc. The Foundation renews the certification every 2 years, however, its experts also visit the sites regularly for sustainability checks during the 2 years, therefore ensuring quality control. To become a sustainable restaurant, a restaurant should meet 7 sustainability criteria. The criteria are as follows:

- avoiding the use of palm oil;

- avoiding polystyrene packaging and reducing the usage of straws (only available on request);

- offering at least 2 vegetarian dishes;

- using at least $30 \%$ domestic raw materials;

- using at least 1 bio-certified raw material or product;

- using at least 1 environmentally-friendly cleaning agent;

- on-going efforts to reduce local environmental impact.

In addition to meeting the criteria, long-term commitment is also important. In general, representatives of restaurants visit the Foundation to obtain certification. The qualification is for 2 years, after which the above criteria are re-examined, looking at what has been improved and what the goals are for the next 2 years. At the beginning of the qualification process, a detailed questionnaire is used to map out where a given restaurant could make more sustainable or responsible decisions, be it energy management, waste management or charity action (vendeglatasmagazin.hu, 2019). Restaurant managers are also involved in the process prior to the launch of the initiative. The starting point is the idea that green investments can bring economically rewarding benefits to restaurants, and that a brand can be built if someone cares about the environment. The certification makes it easier to choose a restaurant for those who also take environmental considerations into account when eating their lunch or dinner. Going to a restaurant can be not only an experience and type of relaxation, but also part of a "green" lifestyle. Eating in a sustainable restaurant is both a prestige and an exemplary behaviour (Szám, 2017; theviewmagazine.eu, 2019). Currently (by October 2020)², 53 restaurants have the Sustainable Restaurant certification in Hungary.

It can be stated that the number of catering facilities wishing to join the network of Sustainable Restaurants is constantly increasing, while the certification becomes better-known among the general public. Growing popularity and consumer awareness increase the market opportunities for restaurants, while they are increasingly contribute to meeting sustainability goals. Overall, the sustainable restaurant initiative has its part in the recognition of competitive advantages regarding sustainability

\footnotetext{
${ }^{2}$ Check at: https://gasztrohos.hu/vendeglatohelyek.
} 
measures, the return on related developments and investments, and the creation of social values that cannot be expressed in money. The initiative is proof that sustainability in a restaurant is not only about recycling and using biodegradable packaging, but it could mean much more than this.

\subsection{Safe place certification}

The COVID-19 or coronavirus pandemic, which erupted at the end of 2019 and expanded in 2020, is among the most turbulent and significant changes affecting businesses, economies and societies. The pandemic has adversely affected businesses in several respects, as well as social relationships and people's daily lives throughout the world. Unfortunately, the virus epidemic is still going on, endangering people's lives and the operation of businesses. The tragedies and shock caused by COVID-19 have changed many things world-wide. A series of new phenomena have emerged, one of them being an even greater appreciation of health and life.

We can say that the pandemic has re-written or is re-writing the market, one of the determining factors of which is hygiene, or even more so the appreciation of "visible hygiene". For this reason, hygiene has become a fundamental factor in the choice of consumers and customers, especially in those activities or sectors where transactions between the organisations and the customers necessarily or typically take place through physical presence, physical connections or personal contact.

In response to the negative effects of the coronavirus on businesses and their customers, in June 2020, CertUnion developed a set of supportive criteria helping business actors creating health-friendly working conditions in epidemic situations and informed customers and guests about these efforts. The idea is based on the "Clean \& Safe Stamp " introduced by the Portuguese Tourism Agency (Turismo de Portugal) in early 2020. The point of this is that the certification, and the logo designed to authenticate it, informs customers that the business is making efforts to safeguard the health of customers. It is a commitment to comply with health-safety regulations issued by the National Tourism Authority according to National Health Authority guidelines.

\section{About the certification ${ }^{4}$}

SafetyPlace ${ }^{\text {tw }}$ is a set of criteria designed to support the management of epidemics for all market participants. It specifies how to deal with client spaces, catering facili-

\footnotetext{
${ }^{3}$ See the website for details: https://portugalcleanandsafe.com/en

${ }^{4}$ This section is based on the information available from the following websites: https://certunion.com/safetyplace-biztonsagosnak-nyilvanitva/ https://safetyplace.hu/?utm_source=certunion. com\&utm_medium=banner\&utm_campaign=CertUnion_SafetyPlace_2020
} 
ties, accommodation, etc., to minimize the risk of further infection or transfection between individuals present. The manual, the basis of the criteria system, was compiled with the professional support of the staff from the Hungarian National Blood Transfusion Service (Országos Vérellátó Szolgálat) and the BSL-4 laboratory of the University of Pécs.

One of the advantages of SafetyPlace ${ }^{\mathrm{rm}}$ is that it is not an absolutely separate entity, but can be integrated with existing management systems (ISO 9001, ISO 14001, etc.), thus, it does not impose an additional burden on companies. The manual on which the certification is based was developed in accordance with relevant regulations, therefore, it was not necessary to figure out how to regulate, but to rely on existing regulations that had already been in place.

Obtaining the qualification, based on experience, takes 2-4 weeks, depending on how prepared the company is. In doing so, the company's occupational safety, health and hygiene practices are reviewed and compared with the manual. Then, for compliance, in areas where there are shortcomings, they correct and replace them according to the manual. An important part of the process is staff training. The implementation of the measures is checked by auditors on the basis of a checklist, upon completion of which the organisation receives the SafetyPlace ${ }^{\text {tw }}$ certification. The use of the certification and logo is valid under annual inspections. This demonstrates that the company is making an outstanding effort to minimise the risks posed by epidemics. With the certification, the company becomes entitled to a certificate of compliance and to use the SafetyPlace ${ }^{\mathrm{tx}}$ logo in its marketing communications. In addition, CertUnion operates a public database ${ }^{5}$ accessible to all, where the public can search for companies with SafetyPlace ${ }^{\mathrm{Tx}}$ certification and see which companies are worth visiting, especially in case of any adverse health situations.

\section{Benefits offered by Safety Place ${ }^{\mathrm{TM}}$ certification $^{6}$}

CertUnion's public opinion poll ${ }^{7}$ shows that $94 \%$ of those surveyed expect businesses to be more cautious during a pandemic, and $88 \%$ feel the need for the location to have some sort of confirmation for this. In a survey among businesses, in which 100 business leaders were enquired, found that $58 \%$ of businesses rate epidemiological precautions and their communication as important, and 36\% consider it as extremely important. The majority of businesses surveyed (64\%) would

\footnotetext{
${ }^{5} \mathrm{https}: / /$ safetyplace.hu/safetyplace-minositett-helyek/

${ }^{6}$ This section is based on information available from the following websites: https://certunion.com/jarvanyugyi-ovintezkedesek-nem-eleg-jonak-lenni-annak-is-kell-latszani/; https://safetyplace.gr8.com/,,https://safetyplace.hu/?utm_source=certunion.com\&utm_medium=banner\&utm_ campaign=CertUnion_SafetyPlace_2020

${ }^{7}$ A survey of 1,000 people among the Hungarian population over the age of 40 .
} 
find a certification useful in this regard, which inspires confidence in customers, making it an excellent marketing tool and giving them a competitive advantage over their competitors. The benefits offered by the Safety Place ${ }^{\mathrm{Tw}}$ certification can be summarised as follows:

- safe customer and guest reception;

- safe working environment for the employees of the company;

- trusted certificate issued by an independent organisation;

- the qualification is authentic for both customers and guests;

- registration in a public database in which certified companies and service providers can be searched for;

- use of the SafetyPlace ${ }^{\text {rix }}$ certification and logo in marketing communication. As a result, more customer traffic is expected because market research shows that $88 \%$ of people would choose a qualified place, which means higher sales and more revenue. By October 2020, 5 companies had been certified, including a winery, a fleet management company, an enterprise management company, a PR and advertising agency and a consulting company. In fact, this certification initiative is a good example of responsible innovation, since it meets the requirements of ethical acceptability, sustainability and societal desirability.

\section{Questions / tasks}

1. Do you think you would like to dine at a restaurant that has a Sustainable Restaurant certification? What are the pros and cons of your choice? Explain and justify your answer.

2. How would you extend or modify the qualification criteria? How would you increase the effectiveness and efficiency of the initiative?

3. What are the advantages, limitations and possible drawbacks of the initiative?

4. What are the potential benefits for restaurants, guests and society?

5. What do you think - would you rather go to a shop, store, restaurant, etc. that has such a certification? What are the pros and cons of your choice? Explain and justify your answer.

6. What are the advantages, limitations and possible drawbacks of this certification?

7. Is the certification really a competitive advantage? Does it really differentiate certified organisations from competitors?

8. What are the benefits of this certification for companies, customers and society? 


\section{References}

English website of Heroes of Responsible Dining Foundation: Responsible Dining. Retrieved September 14, 2020 from https://www.gasztrohos.hu/en.

Hungarian website of Heroes of Responsible Dining Foundation: Étteremkereső. Retrieved September 14, 2020 from https://gasztrohos.hu/vendeglatohelyek

Hungarian website of Heroes of Responsible Dining Foundation. Fenntartható Vendéglátóhely. Retrieved September 14, 2020 from https:/gasztrohos.hu/vedjegy/fenntarthato-vendeglatohely

Hungarian website of Heroes of Responsible Dining Foundation: Fenntartható Vendéglátóhely minősítés és hálózat. Retrieved September 14, 2020 from https://www.gasztrohos.hu/fenntarthato-vendeglatohely-minosites

Papp, A. I., \& Lugasi, A. (2018). Fenntarthatóság a vendéglátásban. ÚjDiéta, 27(2-3), 19-22.

Szám, D. (2017). Környezetbarát gasztronómia. Interjú Varga Judittal a Felelős Gasztrohős Alapítvány ügyvezető igazgatójával. Lépések a fenntarthatóságfelé, 22(2), 16-17.

theviewmagazine.eu (January 23, 2019). Fenntartható vendéglátóhelyek. Retrieved September 22, 2020 from https://theviewmagazine.eu/fenntarthato-vendeglatohelyek/

vendeglatasmagazin.hu (February 2, 2019). A Felelősség az alapoknál kezdődik. Retrieved September 22, 2020 from https://vendeglatasmagazin.hu/felelosseg-az-alapoknal-kezdodik/

Website of CertUnion. Járványügyi óvintézkedések: nemelégjónaklenni, annak is kellátszani! Retrieved September 7, 2020 from https://certunion.com/jarvanyugyi-ovintezkedesek-nem-eleg-jonak-lenni-annak-is-kell-latszani/

Website of CertUnion. SafetyPlace ${ }^{\mathrm{ma}}$ : biztonságosnak nyilvánítva. Retrieved September 8, 2020 from https://certunion.com/safetyplace-biztonsagosnak-nyilvanitva/

Website of Clean \& Safe. You're safe with us. Take a deep breath and enjoy. Retrieved September 12, 2020 from https://portugalcleanandsafe.com/en

Website of Safety Place. SafetyPlace a munkavállalókés a vendégek egészségének szolgálatában. Retrieved September 7, 2020 from https://safetyplace.hu/?utm_source=certunion.com\&utm_ medium=banner\&utm_campaign=CertUnion_SafetyPlace_2020

Website of Safety Place. Végreegy megoldás az üzletek és vendéglátóhelyek tulajdonosainak, hogyan tudnak szembeszállni a járvány negatív hatásaival. Retrieved October 28, 2020 from https:// safetyplace.gr8.com/ 



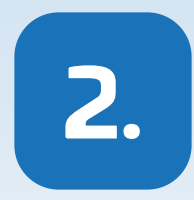

\title{
SUSTAINABLE DEVELOPMENT IN NON-GOVERNMENTAL ORGANISATION SECTOR
}

\section{Agnieszka Chomiuk}

Poznań University of Economics and Business

\begin{abstract}
The described project assumes the development of a new method for solving the problem of homelessness, in particular, with regard to the field of supporting people in an exceptionally difficult situation or those suffering from mental disorders and/or addictions to achieve independence and overcome problems.

The aforementioned project is the first attempt at implementing this method in Poland. The basic assumption of the method is to solve the main problem of a person in the homelessness crisis, which is the lack of housing, and only then to provide support in solving other problems.

The aim of the chapter is to give rise to discussion on the innovative solutions implemented by one of the local government to remedy the problems of homeless people. The issue is based on SDGs.

The second described case study is the "Safe Future of People with Intellectual Disability"-implemented by the Polish Association for People with Intellectual Disability-reflecting the tested model based on support circles, i.e. social support networks in order to empower people with intellectual disabilities.

The main objective of the "Safe Future" model is to develop and implement solutions that ensure legal, financial and social security of people with intellectual disabilities in situations where they have lost the support of the family. The concept of the support circles tested in this model is based on built networks of connections rooted in the social capital generated among the local community.

The last example of sustainable development in the non-governmental sector is Social Cooperative Sunny Hill-as a social enterprise it is a unique entity on the market. It conducts economic activity, the main goal of which is not profit, but social and professional re-integration of people at risk of social exclusion. Contrary to a traditional enterprises, it does not distribute the profit among shareholders, but allocates it to social purposes.
\end{abstract}

Keywords: Housing First method, innovations in solving the problem of homelessness, social capital, support circles, social cooperative, social enterprise. 


\section{2.l. From basic human rights to economic and social profit: solving the problem of homelessness based on the "Housing First" method}

Providing shelter is a compulsory task of the commune, regulated in the act on social assistance (Article 17.(1) (3) of the Act on In the Polish social welfare system). Helping people in the homelessness crisis is largely implemented according to the so-called "ladder model". This model assumes that, firstly, all problems of persons in the homelessness crisis, related to their health, functioning, obligations, addictions and professional activity, should be solved. Only after these problems are resolved, can a homeless person count on aid in the form of housing. Until receiving assistance in the latter, a person in a homelessness crisis may benefit from assistance in the form of shelter at shelters or night shelters. Many years of Polish experience in work on solving the problem of homelessness show that the institutional form of assistance based on shelters and night shelters does not bring the expected results and the percentage of people able to come out of homelessness is low. The process of beating homelessness based on the "ladder model" is often spread out over many years, and the distant perspective of providing housing assistance is demotivating for people in a homelessness situation.

Working with people in a homelessness crisis also proves that the ladder model and institutional help are forms of aid that not every homeless person will be able to use. Such people, for example, are those with mental disorders or addicts who either cannot or are unable to take advantage of the available institutional offer. Due to the lack of alternative methods, such people are exposed to many years of staying in non-residential places, and thus, to death from hypothermia in winter. Homeless individuals who do not take advantage of shelter at institutions generate the need to provide support through frequent visits to emergency medicine facilities, sobering-up stations, seeking food or material assistance. In the autumn and winter months, monitoring municipal services is intensified in the case of these people because the threat to their health and life, and in the summer period, due to the notification of asking for donations.

The Housing First method and its foundations were formulated by Dr. Sam Tsemberis in the 90s of the previous century in New York, at the "Pathways to Housing" organisation (Cendrowicz, 2017). In its first assumptions, the work model was aimed towards people with mental disorders who did not find themselves the help provided by traditional methods and/or used this form of help for many years without the effect of becoming independent. The innovation in this method is reversal of the order in providing help. First, the basic problem is solved, which is the lack of "shelter", and then, intensive support in solving the problems behind long-term homelessness, e.g. mental disorders, addictions, debt, unemployment, social maladjustment, etc. 
The idea of Housing First allows to address the fundamental human right to exit homelessness, in particular, through access to housing-based solutions. It is not something a person has to earn or prove deserving by treatment. The Housing First method also recognises that all people, even those experiencing a homeless crisis, are able to decide for themselves and take responsibility for their lives.

The basic principles of the method include:

- housing is a human right, flats are independent and the rental safety is guaranteed by law;

- support services focus on mental and physical health as well as education, employment, interpersonal skills and are offered for as long as the person needs them;

- the programme's flats are independent and dispersed in the local community;

- client's choice and self-determination are fundamental in therapy;

- recovery orientation;

- a harm reduction approach is used, which assumes that tackling addiction is a long-term process and reducing harm to human well-being is a priority (Pleace, 2014).

The Housing First method has been implemented in Gdańsk, Warsaw and Wrockaw as part of the project. The leader of this project is Towarzystwo Pomocy [Eng. Society for Aid] named after St. Brother Albert's Board of Directors (https:// www.bratalbert.org/czym_sie_zajmujemy.html).

The project partners are:

- Associao para o Estudo e IntegraoPsicossocial (Portugal);

- National Federation for Solving the Problem of Homelessness;

- Warsaw City Hall;

- Wrocław City Hall;

- Gdańsk City Hall.

The problem of homelessness is experienced by about 5,000 people in Warsaw, Wrocław and Gdańsk (https://www.bratalbert.org/projekt-housing-first-najpierwmieszkanie.html). The main goal of the project is to implement a new work model- "Flat First", in cooperation with a foreign partner, the Associao para o Estudo e IntegraoPsicossocial organisation from Portugal, which has many years of experience in using this method (ibidem). The Housing First programme is a method of work addressed to people in a homelessness crisis, in a special situation: suffering from mental disorders and/or addictions, i.e. with so-called double diagnosis and experiencing chronic homelessness manifested by many years (at least 6) of staying in non-residential places, such as: on streets, plots of land, empty spaces, etc. Many years of experience working with people in a homelessness crisis are devoted to people who, for various reasons, were unable to benefit from traditional forms of assistance. 


\section{Questions / tasks}

1. With regard to international human rights treaties and their underlying values, in the Housing First method, the need to respect the rights of people experiencing homelessness are highlighted, including the right to housing. Do you think it is correct to assume that housing assistance is a fundamental right that should be provided in the first instance to a person who needs it?

2. From an economic point of view, investing in the Housing First method is expensive, as it involves providing housing and equipment as well as therapeutic and social support. Being homeless, however, causes long-term costs related to the hospitalisation of people on the streets, work of social services, costs of stay in sobering-up stations, prisons and detention centers, and providing food aid. Thus, what is your approach to the cost of the Housing First method?

3. What are the social costs of the lack of effective methods to overcome homelessness, apart from those economic?

4. What are the conditions for the effectiveness of Housing First?

\subsection{Social capital in building a safe future for people with intellectual disabilities}

Traditionally, disability has been narrowly defined as a strictly medical problem, to which the response is appropriate treatment and rehabilitation. Nowadays, the field of understanding disability has changed significantly. Currently, the functioning of a disabled person, including functioning in society, is at its centre (Antczak, Grabowska, \& Polańska, 2018).

The independent functioning of people with intellectual disability in society is not possible without a built-in, permanent local support system. In Poland, there are various models and forms of assistance for people with intellectual disabilities, under which health, rehabilitation and social services are provided. However, this assistance does not provide conditions for independent functioning of people with intellectual disabilities, which becomes a particularly difficult problem in the event of the death of their legal guardians. This often results in the situation that a person with an intellectual disability must use 24 -hour forms of institutional assistance, even though with such support, she/he could function in his/her natural environment.

The "Safe future of people with intellectual disabilities" model is a comprehensive concept of community support for people with intellectual disabilities in the local community, at their place of residence. The model assumes the preparation of a person with disabilities and their closest local environment to function independently, based on the concept of support circles, i.e. networks of connections between people and institutions. 
The project is implemented in the form of a partnership among nationwide organisations and institutions: the Polish Association for People with Intellectual Disability (Leader), the BORIS Social Initiative Movement Service Office, the "Tęcza" Association and the University of Warsaw. At the local level, in 8 communities, the partners are: Horyzont Association, Gmina and City of Goleniów, Jarosław, Olsztyn and Ostróda poviats, as well as the districts of Nidzica, Elbląg, Suwałki, Gdańsk (https://psoni.org.pl/; https://boris.org.pl/; https://tecza.org).

The Polish support system for people with intellectual disabilities was dominated by a model which assigned responsibility for their care to the family, and in the event of loss of family support, to institutional help. Apart from the difficult availability of places in specialised institutions, this solution causes the marginalisation of people with intellectual disabilities by "shutting" them out for many years in institutions and trauma related not only to the loss of family members, but their entire life.

Provision of support in their natural local environment would be a much lower economic cost for the state, social for the environment and individual for a disabled person. This would be possible in a local environment with high social capital, created networks of institutional connections and social ties as well as trust, on the basis of which the support system could be built. Due to the low level of social capital in Poland, measures should be taken in the direction of its increase, enabling the creation of support circles around people with intellectual disabilities in their local community.

The model assumes the creation of support circles in each local community, formed around a person with intellectual disability. Each person and family would develop their own plan for the future, including that financial, with regard to housing, health and functioning in the local community. Additionally, in each of the tested environments, a Coalition of Allies would be created and social as well as educational campaigns carried out to raise the social awareness of inhabitants (https://kregiwsparcia.pl/model-bezpieczna-przyszlosc-2/).

The model is based on the potential of local social services and infrastructure, as well as social capital. Building social capital in the local community of people with intellectual disabilities is like weaving a strong network around them. Mutual ties, trust, activity and cooperation can create circles of support that will ensure the safe functioning of people with disabilities, with maximum commitment and decision-making based on a strong social support from the family, municipal institutions, neighbours, services and organisations.

\section{Questions / tasks}

1. Can social capital be the foundation for building support circles around people with intellectual disabilities? 
2. How can we multiply social capital in the local environment?

3. Is the community support model the right direction to help people with intellectual disabilities?

\subsection{Profit plus or about the social and economic value of social entrepreneurship on a concrete example}

The Słoneczne Wzgórze Foundation [Eng. Sunny Hill Foundation] was established in 2012 to provide comprehensive assistance to people with disabilities and their families in the area of personal development and social and professional activation through, inter alia, education, rehabilitation and integration. This assumption was implemented over the years, primarily as part of Occupational Therapy Workshops (OTW).

Wielobranżowa Spółdzielnia Socjalna Słoneczne Wzgórze [Eng. Sunny Hill Multi-sector Social Cooperative] was established in 2014 as a place of professional activation for participants of OTW and other people at risk of social exclusion (http://sunnyhill.pl/).

Profit in a social cooperative is important. Its generation allows for investment in the social and professional reintegration of members and the implementation of public benefit objectives. At the same time, profit in the cooperative is of secondary nature, because the gainful activity is not an end in itself, it is only intended to pursue a social mission.

The main goal of the Cooperative's activity is to restore people at risk of social exclusion from the labour market.

The economic activity of the Cooperative includes (http://sunnyhill.pl/):

- catering and catering services;

- educational and artistic workshops;

- service of training and study visits;

- production of hand-made art products;

- service of special events for children;

- providing accommodation.

For socially-responsible activities, including the area of relations with employees and the local community, respect for the environment, principles of fair relations with stakeholders, the Cooperative was awarded the title: "Responsible and Socially Sensitive Entrepreneur".

The establishment of the Sunny Hill Multi-sector Social Cooperative was a response to the pressing problem regarding the low level of employability of the Foundation's charges. People with disabilities are treated in a discriminatory manner on the labour market, and company policies are rarely aimed at equality and adapting workplaces to the needs of people. 
The Cooperative conducts extensive activities in the field of professional integration, creating workplaces adapted to the needs of people with disabilities (http:// sunnyhill.pl/). It mainly employs people at risk of social exclusion, including those with disabilities. Employment in the cooperative is constantly increasing-from 5 people employed in 2014 to 13 in 2017.

The cooperative invests in the development of employees by improving their skills through a system of courses and training. It creates the possibility of social and professional activation among OTW participants. The cooperative also prepares people with disabilities to enter the open labour market, who receive the comprehensive service of social and professional reintegration through the cooperation of the cooperative and OTW. The cooperative supports its employees and members comprehensively through recreational, cultural and environmental activities. The members of the cooperative have the opportunity to participate in the Teatr Poza Sztuką [Eng. Theatre Beyond Art] programme, a project that promotes culture among children and youth through various theater forms, popularising vocal art, author's songs, etc.

The cooperative takes an active part in partnership projects based on permanent cooperation, thus, spreading good practices in the area of socio-professional reintegration among people at risk of social exclusion. It cooperates with social economy entities, local government units, social welfare institutions, reintegration entities and organisations dealing with people experiencing disabilities (Chomiuk \& Gabryelewicz, 2017).

\section{Questions / tasks}

1. Is it possible to subordinate the economic activity to a social mission?

2. Social enterprises often operate on the verge of profitability, and are sometimes subsidised by public institutions. Is such activity justified from an economic point of view?

3. What added value do social enterprises generate?

4. Is the social enterprise a significant employer on the labour market considering the group of people employed there?

\section{References}

Antczak, R., Grabowska, I., \& Polańska, Z. (2018). Podstawy i źródła danych statystyki osób niepełnosprawnych. Statystyka $w$ Praktyce, 2(681) 2018, 21-43.

Cendrowicz, D. (2017). Ograniczanie występowania zjawiska bezdomności na przykładzie programu Housing-First. Ekonomia Społeczna, 2(2017), 37-47.

Chomiuk, A., \& Gabryelewicz, K. (2017). Efektywność przedsiębiorstw społecznych w realizacji celów społecznych i biznesowych. In M. Frączek (Ed.), Ekonomia Społeczna, 1(2017). Uniwersytet Ekonomiczny w Krakowie, Małopolska Szkoła Administracji Publicznej. 
http://sunnyhill.pl/

https://kregiwsparcia.pl/idea-projektu/

https://kregiwsparcia.pl/wp-content/uploads/2019/02/Model-BEZPIECZNA-PRZYSZ\%C5\%81OS\%CC\%81C\%CC\%81.pdf

https://kregiwsparcia.pl/wp-content/uploads/2019/02/ABC_W-kierunku-udanego-z\%CC\%87ycia-doros\%C5\%82ych-oso\%CC\%81b_PORADNIK.pdf

http://www.ostoja.org.pl/pliki/Cytowska_B.pdf

https://www.bratalbert.org/czym_sie_zajmujemy.html)

https://www.bratalbert.org/projekt-housing-first-najpierw-mieszkanie.html

https://psoni.org.pl/;

https://boris.org.pl/;

https://tecza.org

Pleace, N. (2014). The case for Housing First in the European Union: A critical evaluation of concerns about effectiveness. European Journal of Homelessness, 7(2).

Links to websites and publications in which the topics presented are more widely described: https://www.czynajpierwmieszkanie.pl/najpierw-mieszkanie/

http://bazekon.icm.edu.pl/bazekon/element/bwmeta1.element.ekon-element-000171530790 https://endhomelessness.org/resource/housing-first/

https://www.homelesshub.ca/solutions/housing-accommodation-and-supports/housing-first https://www.feantsaresearch.org/public/user/Observatory/12-3_EJH_2018_v04.pdf

https://msap.uek.krakow.pl/publikacje/

https://www.ekonomiaspoleczna.gov.pl/Lista,przedsiebiorstw,spolecznych,4069.html

https://przedsiebiorstwospoleczne.pl/dlaczego-i-kiedy-przedsiebiorstwo-jest-spoleczne/

https://www.ekonomiaspoleczna.gov.pl/Ekonomia,Spoleczna,i,Solidarna,4016.html

http://www.revesnetwork.eu/index.php

https://ec.europa.eu/growth/sectors/social-economy_en

https://www.socialeconomy.eu.org/

https://www.socialplatform.org/service/social-economy-and-entrepreneurship/

https://plan.ca/

https://planinstitute.ca/

http://helensandersonassociates.co.uk/

https://inclusive-solutions.com/

https://www.community-circles.co.uk/

https://sharedlivesplus.org.uk/

https://www.rytmus.org/

https://www.livesthroughfriends.org/index.php

https://www.petagma.gr/

https://arcwestchester.org/

https://www.hse.ie/eng/ 


\title{
3.
}

\section{SOCIAL SUPERMARKETS AS A SOLUTION TO FOOD WASTE AND ISSUES OF POVERTY}

\author{
Blaženka Knežević \\ Faculty of Economics and Business, University of Zagreb
}

Abstract: The main objective of this chapter is to present and discuss a possible solution to food waste as a problem occurring in traditional food supply chains, on the one hand, due to food overproduction, and on the other, poverty as a result of economic and pandemic crisis in Europe.

The structure of the chapter covers two areas:

1. Food waste as a problem in food supply chains.

2. Reduction of poverty by implementing social supermarkets as new players in the food supply chain.

Keywords: food waste, poverty, social supermarkets. 


\subsection{Food waste as a problem in food supply chains}

The food supply chain is formed of interconnected enterprises from the field or farm to the consumer's table. Its structure is specific compared to supply chains of other product types (e.g. cars, footwear, clothing or electronic products). Prospective participants in the food supply chain and the links between them are shown in Figure 1. The participants of the supply chain are agricultural producers: farmers, gardeners, farmers, fishermen, fruit and grape producers, who sell their products: (1) directly to consumers, or (2) to an intermediary organisation (wholesale, retail, hotel, restaurant, etc.), or (3) to the processing industry as raw materials, which will turn them into finished food products and distributes them among the market. The manufacturing industry can also sell its products to consumers directly or through one or more intermediaries.

The number of intermediaries that may be present in the food supplychain is not limited, and each participant of the chain invests resources and adds value to the food product delivered to the final consumer. During its way through the chain, food products are transferred between chain links in the same or an altered physical from. Any investment of resources in the supply chain causes an increase in costs of the supply chain, and leads to an increase in the final price of the product. However, if the perceived value of the final product sold to consumer is greater than or equal to the cost-price, this will result in consumer satisfaction.

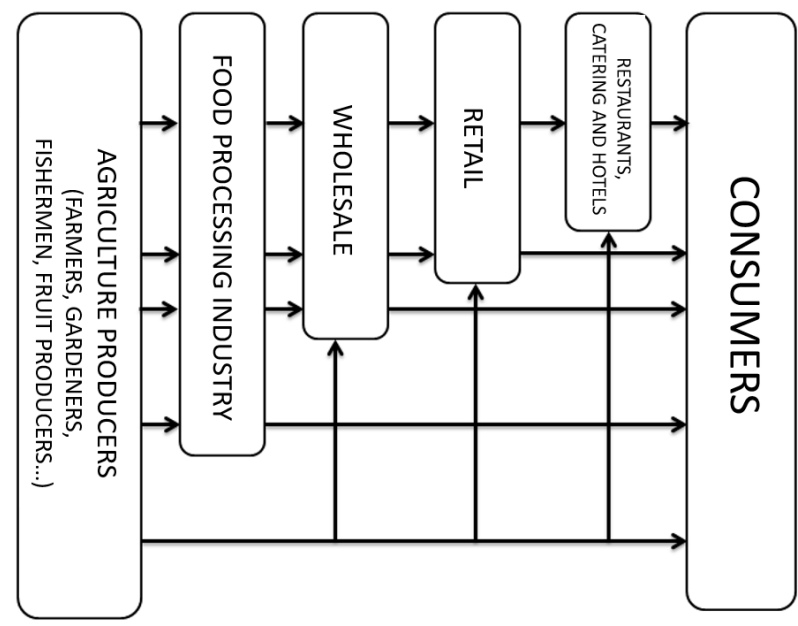

Figure 1. Members and connections in food supply chains

Source: Adapted according (Pullman \& Zhaoui, 2012, p. 2).

The processes that take place in food supply chains can also be observed sequentially. In Figure 2, the basic processes in the food supply chain are shown. First, 
crops are grown, animals are raised or hunted (e.g. fish), then the food produced is stored and either distributed on the market or processed. In the processing of input raw materials, finished food products are pro-produced, which are re-stored and delivered through the market distribution system to the final consumer for consumption.

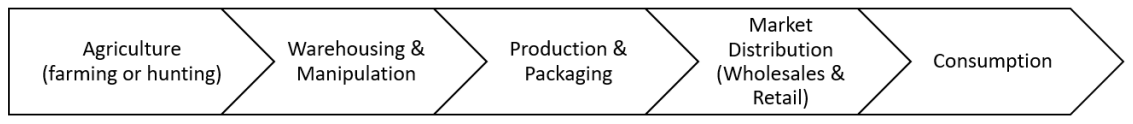

Figure 2. Basic processes in food supply chains

Source: Adapted according (Lipinski et al., 2013, p. 5).

Food loss in the supply chain, as a term, refers to all food that spoils, spills, or significantly loses quality so that it does not reach the end-consumer through the supply chain at all (Parfitt, Barthel, \& Macnaughton, 2010). Food losses occur at the stages of production, storage, processing and physical distribution as an undesirable consequence of business processes or technical constraints of storage, infrastructure, packaging or marketing activities.

In contrast, the term food waste refers to food that is of appropriate quality and suitable for human consumption, but ultimately, is not consumed for some reason. Food waste usually occurs in retail or in the consumption phase, and is the result of consumers' negligence or a conscious decision to throw away food (Lipinski et al., 2013, p. 4; Koivupuro et al., 2012). In the study by Knežević, Kurnoga, and Anic (2019), it is demonstrated how awareness and knowledge directly affect food waste levels among the student population.

Food losses and waste can be measured by the weight of spoiled food and by the energy value in kilocalories. For example, the FAO report (2011) concludes that approximately 1.3 billion tons of food are lost annually. According to Lipinski et al. (2013, p. 7), about $56 \%$ of the total food waste in the world occurs in the developed world: North America, Oceania, Europe, and industrialised parts of Asia (China, Japan, and South Korea). Europe accounts for $14 \%$ of the total kilocalories of food thrown away on a global scale. In addition, Lipinski et al. (2013, p. 9) emphasize that between developed and underdeveloped countries, significant differences can be observed according to the stages of the supply chain in which food losses and waste occur. In North America and Oceania, more than $60 \%$ of food is thrown away during the consumption phase, while approx. $15 \%$ in the agricultural production phase. In Europe, more than half of food is thrown away at the consumption stage, about a quarter in the production phase. In Latin America, food is wasted equally during the production, consumption and storage phases (between 20 and 25\% in each phase).

Principato, Secondi and Pratesi (2015) give the explanation that food losses at the initial stages of the food supply chain occur because of the limitation of 
technical, financial or managerial resources. While in the final stages they occur due to unfavourable storage methods, poor purchase planning, impulsive buying large quantities if unnecessary food, spoilage of food, preparation of inadequate quantities, etc. (see studies: Stefan, van Herpen, Tudoran, \& Lähteenmäki, 2013; Principato et al., 2015).

Needless to say, food losses and waste have multiple negative consequences that can be classified as: economic, social and environmental (Principato et al., 2015).

\section{Questions / tasks}

1. Provide some real-life examples how food is wasted: (1) at farms, (2) in fishery, (3) at food factories, (4) in transport, (5) at warehouses, (6) at super- or hypermarkets, (7) restaurants, (8) your household.

2. In your opinion, who is the most responsible (as a part of a food-supply chain) for problem of food waste?

3. Do you have some ideas how to deal with food waste when it occurs?

4. Why can food surpluses be found across food supply chains in developed countries? How should consumers act to override food overproduction in the future?

5. Research approximations as to how much food is wasted globally, in your region or country. Comment: did you expect such numbers?

6. Discuss what the economic, social and environmental consequences of food waste are.

7. Could governments act in some way to prevent food waste in wholesale and retail companies as intermediaries in food distribution?

\subsection{Reduction of poverty by implementing social supermarkets as new players in food supply chains}

The recent economic crisis across Europe (2008-2014) caused significant growth of people living at risk of poverty or social exclusion. According to available data (see: EU, 2014a, b and c), in the EU, there was almost $1 / 4$ of citizens who lived at risk of poverty or social exclusion. Moreover, $1 / 10$ of all EU citizens experience severe material deprivation and cannot afford some basic household facilities, such as telephones, washing machines, heating, etc. More than 1/10 of the EU population is officially registered as unemployed. All poverty indicators for EU-27 Member States showed that the social situation worsened during the economic crisis (see: Figure 3), and due to the on-going COVID-19 pandemic, we can expect further continuance of this trend. 


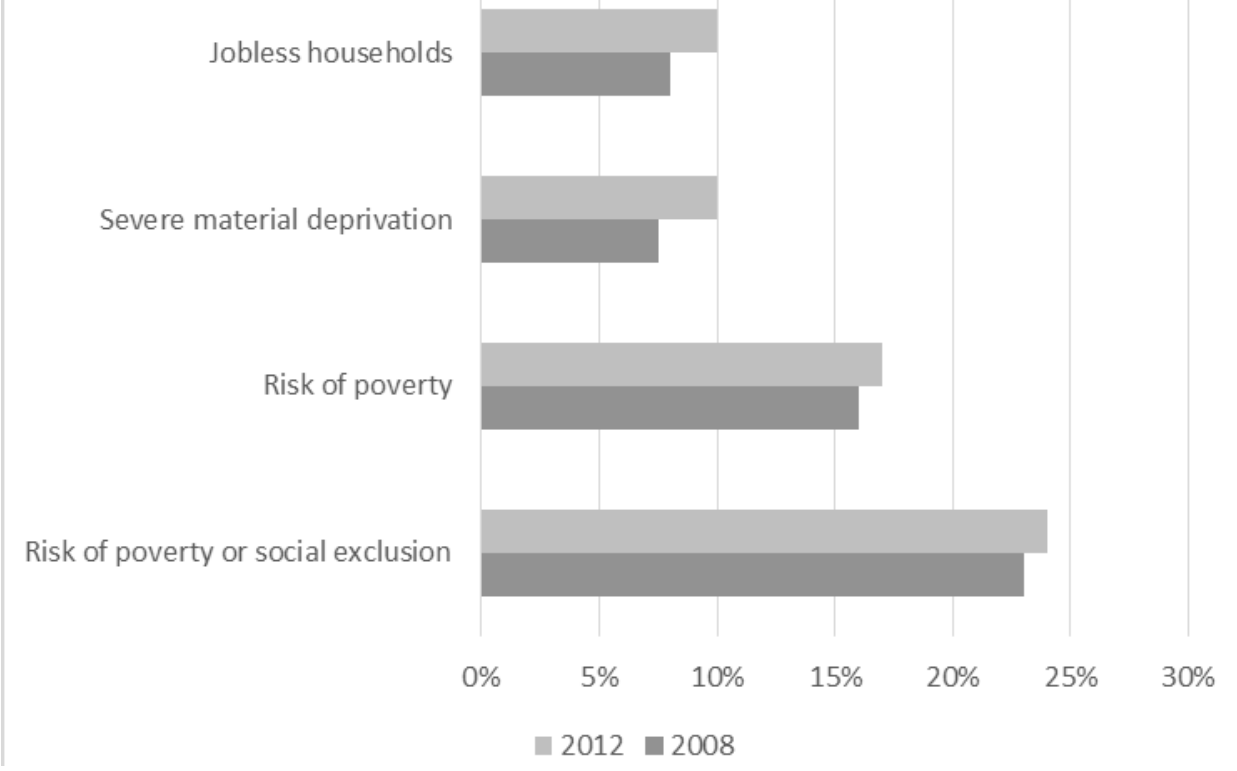

Figure 3: Indicators of the social situation in the EU during previous economic crisis

Source: (Petkovic, Knežević, \& Pindžo, 2017) based on official EU data (EU, 2014a, b and c).

Therefore, social supermarkets emerged across Europe as an answer to this emerging problem. As a new form of organisations, social supermarkets are focused on those groups of customers with low income or who are in a situation of severe material deprivation. However, the level of development and type of their operational activity varies from country to country. Despite the fact that there is still no common definition of social supermarkets (because it should be broad enough to integrate all variations developed and existing on different markets), many different definitions and determinations of the term social supermarkets can be found.

For instance, social supermarket is defined as "a small, non-profit oriented retailing operation offering a limited assortment of products at symbolic prices, primary in a self-service manner. Those authorised for shopping are only people with severe financial situations. The products are donated by food production and retail companies free-of-charge, as they are edible but not marketable due to small deficiencies/flaws. The achieved profit is reinvested into social projects" (Schnedlitz, Lienbacher, \& Holweg, 2011). Holweg and Lienbacher (2011) define social supermarkets as food oriented retailers selling food to a restricted group of people living in or at risk of poverty. According to the definition given by Holweg and Lienbacher (2011), social supermarkets are non-profit organisations, which base their activity on volunteerism and charity, and if they generate any profits, they use 
them for charitable activities. In addition, in the definition by Sellmeister (2010), it is stated that "social supermarkets are organisations that provide cheap food that is no longer useful for the common trade to people who are in situations of poverty".

According to Maric and Knežević (2014), social supermarkets are a new retail format that foster positive social change by fulfilling material needs of the socially disadvantaged groups and giving them an opportunity to preserve their dignity in an environment where they can choose various kinds of goods at extremely low prices. Some social supermarkets offer goods free-of-charge, as explained by Knežević and Skrobot (2018). In addition, Maric, Knežević, and Dzambo (2015) state that "social supermarkets represent a specific form of social entrepreneurship, because they are voluntary non-profit organisations and a special form of retail which supply socially vulnerable individuals with basic necessities", and they claim that social supermarkets should be observed as a specific form of social innovation. Due to the fact that they promote strengthening social capital, social cohesion and develop social responsibility among all stakeholders involved in the distribution of food to socially-endangered citizens.

Within the context of food supply chains, social supermarkets position themselves as an intermediator between traditional members of food supply chains and consumers who are in material deprivation. Therefore, it can be said that social supermarkets serve as leverage, trying to establish equilibrium between the occurrence of food surpluses and food waste in traditional supply chains and the occurrence of food poverty among the population in a given area on the other side (Knežević, Maric, \& Sucur, 2017).

Table 1. Characteristics of selected social supermarkets in Croatia

\begin{tabular}{|l|l|l|l|}
\hline \multicolumn{1}{|c|}{$\begin{array}{c}\text { Location } \\
\text { of social } \\
\text { supermarket }\end{array}$} & \multicolumn{1}{|c|}{ Osijek } & \multicolumn{1}{c|}{ Našice } & \multicolumn{1}{c|}{ Rijeka } \\
\hline $\begin{array}{l}\text { Name of } \\
\text { organisation }\end{array}$ & $\begin{array}{l}\text { Rijeka ljubavi } \\
\text { (Eng. River of Love) }\end{array}$ & $\begin{array}{l}\text { Dar dobrote } \\
\text { (Eng. Gift of Goodness) }\end{array}$ & $\begin{array}{l}\text { Kruhsv. Elizabete } \\
\text { (Eng. St. Elizabeth's Bread) }\end{array}$ \\
\hline End users & 3,500 individuals & 700 individuals & 2,000 individuals \\
\hline $\begin{array}{l}\text { Opening } \\
\text { hours }\end{array}$ & $\begin{array}{l}\text { flexible, dependable on dona- } \\
\text { tions, announced via social } \\
\text { networks, at least 2 days a week }\end{array}$ & $\begin{array}{l}\text { Monday-Tuesday, 5:00-7:00 } \\
\text { p.m., and 1 } \text { st Saturday of }_{\text {each month, 9:00-11:00 a.m. }}\end{array}$ & $\begin{array}{l}\text { Monday-Friday, 8:00 a.m.- } \\
\text { 4:00 p.m. }\end{array}$ \\
\hline Assortment & $\begin{array}{l}\text { number of SKUs depends on } \\
\text { donations, approx. 80\% food, } \\
\text { 20\% toiletries }\end{array}$ & $\begin{array}{l}\text { number of SKUs depends } \\
\text { on donations, approx. 70\% } \\
\text { food, 30\% toiletries }\end{array}$ & $\begin{array}{l}\text { number of SKUs depends } \\
\text { on donations, approx. 80\% } \\
\text { food, 20\% toiletries, and } \\
\text { other products }\end{array}$ \\
\hline Prices & $\begin{array}{l}\text { goods are distributed for free, } \\
\text { package for life (14 products } \\
\text { monthly to each household) }\end{array}$ & $\begin{array}{l}\text { goods are distributed for } \\
\text { free, based on point system }\end{array}$ & $\begin{array}{l}\text { goods are distributed for } \\
\text { free }\end{array}$ \\
\hline
\end{tabular}


Social supermarkets as a solution to food waste and issues of poverty

\begin{tabular}{|l|l|l|l|}
\hline \multicolumn{1}{|c|}{$\begin{array}{c}\text { Location } \\
\text { of social } \\
\text { supermarket }\end{array}$} & \multicolumn{1}{|c|}{ Osijek } & \multicolumn{1}{|c|}{ Našice } & \multicolumn{1}{|c|}{ Rijeka } \\
\hline $\begin{array}{l}\text { Additional } \\
\text { services }\end{array}$ & $\begin{array}{l}\text { delivery to disabled people by } \\
\text { volunteers, no own vehicle }\end{array}$ & $\begin{array}{l}\text { delivery to disabled people } \\
\text { by own vehicle, planned } \\
\text { workshops in field of psy- } \\
\text { chosocial development }\end{array}$ & $\begin{array}{l}\text { delivery to disabled people, } \\
\text { systematically organised } \\
\text { fundraising activities (an- } \\
\text { nual-Young against Hun- } \\
\text { ger); on Saturdays at large } \\
\text { retail chains stores “or- } \\
\text { ange" volunteers), futsal } \\
\text { tournaments, lunch with } \\
\text { the homeless }\end{array}$ \\
\hline Location & $\begin{array}{l}\text { close to city centre, space is do- } \\
\text { nated by the local government }\end{array}$ & $\begin{array}{l}\text { close to city centre, space } \\
\text { donated by an individual }\end{array}$ & $\begin{array}{l}\text { close to city centre, space } \\
\text { provided by local Catholic } \\
\text { church }\end{array}$ \\
\hline Promotion & $\begin{array}{l}\text { reports in mass media, You- } \\
\text { Tube channel, active Facebook } \\
\text { profile, leaflets, promotion at } \\
\text { local schools, organisation of } \\
\text { events }\end{array}$ & $\begin{array}{l}\text { reports in mass media, ac- } \\
\text { tive Facebook profile, leaf- } \\
\text { lets, events }\end{array}$ & $\begin{array}{l}\text { reports in mass media, ac- } \\
\text { tive Facebook profile, leaf- } \\
\text { lets, events }\end{array}$ \\
\hline
\end{tabular}

Source: Own research.

There is also a discussion on their role and characteristics as a new retail format (see: Lienbacher, 2013, pp. 77-138; Bogetic, Petkovic, \& Knežević, 2018). This discussion is takes elements of retail mix into account, such as assortment, prices, location, service and promotion, and establishing distinction towards other retail formats, especially towards convenience stores, hard discounters and traditional supermarkets. In Table 1, the characteristics of 3 good examples of social supermarkets in Croatia are shown.

\section{Questions / tasks}

1. Research official statistical data as to how many people in your country live in poverty or material deprivation. Interpret the results in absolute and relative numbers. Does the situation seem to be changing over time (for instance from 2008 to date)?

2. According to your knowledge, are there any social supermarkets available in your city? If so, conduct small online research on their operation: location, scope of work, number of engaged volunteers, sort of events they organise, channels of communication with stakeholders, connections with religious institutions, etc.

3. Are there some other non-profit organisations dealing with food distribution to people in need? Are they supported by government or religious institutions? How are they related to official welfare systems? 
4. How would you organise the work of a social supermarket if there is larger need (severe poverty in your population) than available food supplies on an everyday basis?

\section{References}

Bogetic, Z., Petkovic, G., \& Knežević, B. (2018). Retail mix and its specifics in social supermarkets. In B. Knežević (Ed.), Social supermarkets as entrepreneurial ventures in socially responsible economy. University of Zagreb: Faculty of Economics and Business.

EU (2014a). Poverty and social exclusion. European Commission. Retrieved March 18, 2019 from http://ec.europa.eu/social/main.jsp?catId=751

EU (2014b). Eurostat news release Euro indicators. 31 Jt January 2014. Retrieved March 19, 2019 from http://epp.eurostat.ec.europa.eu/cache/ITY_PUBLIC/3-31012014-AP/EN/3-31012014-AP-EN. PDF

EU (2014c). EU Employment and social situation. March 2014. European Commission. Retrieved March 20, 2019 from http://ec.europa.eu/social/main.jsp?catId=737\&langId=hr\&pubId=7699

FAO (2011). Global food losses and food waste-extent causes and prevention. Food and Agriculture Organization of United Nations. Rome. Retrieved July 8, 2020 from http://www.fao.org/doc$\mathrm{rep} / 014 / \mathrm{mb} 060 \mathrm{e} / \mathrm{mb} 060 \mathrm{e} 00 . \mathrm{pdf}$

Holweg, C., \& Lienbacher, E. (2011). Social marketing innovation: New thinking in retailing. Journal of Nonprofit \& Public Sector Marketing, 23(4), 307-326.

Knežević, B., Kurnoga, N., \& Anic, I. D. (2019). Typology of university students regarding attitudes towards food waste. British Food Journal, 121(11), 2578-2591.

Knežević, B., Maric, I., \& Sucur, Z. (2017). Cross-sector cooperation in the field of food distribution as a response to problems of poverty and material deprivation. Revija za socijalnupolitiku, 24(2), 143-167.

Knežević, B., \& Skrobot, P. (2018). Social supermarkets' profiles in Croatia. In B. Knežević (Ed.), Social supermarkets as entrepreneurial ventures in socially responsible economy. University of Zagreb: Faculty of Economics and Business.

Koivupuro, H-K., Hartikainen, H., Silvennoinen, K., Katajajuuri, J-M., Heikintalo, N., Reinikainen, A., \& Jalkanen, L. (2012). Influence of socio-demographical, behavioural and attitudinal factors on the amount of avoidable food waste generated in Finnish households. International Journal of Consumer Studies, 36(2), 183-191.

Lienbacher, E. (2013). Corporate Social Responsibility im Handel. Springer Gabler.

Lipinski, B., Hanson, C., Lomax, J., Kitinoja, L., Waite, R., \& Searchinger, T. (2013). Reducing food loss and waste (Working Paper of World Resources Institute, UNEP, Washington). Retrieved July 8, 2020 from http://www.wri.org/sites/default/files/reducing_food_loss_and_waste.pdf

Maric, I., \& Knežević, B. (2014). Social supermarkets as a new retail format inspired by social needs and philanthropy-Case of Croatia. In K. Demetri (Ed.), Global business \& economics anthology. Danvers: Business \& Economics Society International, 278-286.

Maric, I., Knežević, B., \& Dzambo, D. (2015). Social supermarket Rijeka as a social innovation in food distribution. In N. Knego, S. Renko, \& B. Knežević (Eds.), Trade perspectives 2015: Innovations in food retailing (pp. 235-245). University of Zagreb: Faculty of Economics.

Parfitt, H., Barthel, M., \& Macnaughton, S. (2010). Food waste within food supply chains: quantification and potential for change to 2050. Philosophical Transactions of The Royal Society, 365, 3065-3081. 
Petković, G., Knežević, B., \& Pindžo, R. (2017). Social initiatives in trade and tourism: The cases of Serbia and Croatia. Ekonomika Preduzeća, 65(1-2), 229-243.

Principato, L., Secondi, L., \& Pratesi, C. A. (2015). Reducing food waste: an investigation on behaviour of Italian youths. British Food Journal, 117(2), 731-748.

Pullman, M., \& Zhaoui, W. (2012). Food supply chain management: Economic, social and environmental perspevctive. Routlege, Taylor and Francis.

Schnedlitz, P., Lienbacher, E., \& Holweg, C. (2011). Strukturanalyse Sozialmärkte in Österreich. Schriftenreihe Handel und Marketing, 74.

Sellmeister, I. (2010). Die ambivalente Rolle von Sozialmärktenim Sozialstaat. Diploma thesis at Fachhochschule FH campus Wien.

Stefan, V., van Herpen, E., Tudoran, A. A., \& Lähteenmäki, L. (2013). Avoiding food waste by Romanian consumers: The importance of planning and shopping routines. Food Quality and Preference, 28(1), 375-381. 



\title{
4.
}

\section{WHY DO CONSUMERS FAIL TO FOLLOW WASTE SEGREGATION RULES? WHAT WOULD MOTIVATE THEM TO OBEY THE REGULATIONS?}

\author{
Magdalena Stefańska \\ Poznań University of Economics and Business
}

Gabriel Grabowski

Contenur Polska Sp. z o.o.

\begin{abstract}
Most of empirical literature on participation in and choice of recycling at the household level has been focused on factors determining the direct cost for households engaging in recycling efforts (Czajkowski, Kądziela, \& Hanley 2012; Huhtala, 2010, Jenkins, Martinez, Palmer, \& Podolsky, 2003). Researchers noticed mixed findings in the literature on the significance of waste collection fees for recycling efforts. There is also a question as whether household recycling efforts represent a social cost, which should be taken into account in cost-benefit analyses of alternative waste treatment systems. Some argue that it should not be calculated, since recycling efforts are, to a large extent, voluntary. But on the other hand, households devote time to segregation, which is, in fact, an alternative cost (Bruvoll \& Nyborg, 2002).

One of the barriers of effective segregation seems to be a low level of awareness on recycling and segregation issues among households. That was also noticed in research conducted by Omran, Mahmood, Abdul Aziz and Robinson (2009). The aim of this case study is to recognise why citizens' knowledge on waste segregation rules is not sufficient enough. Despite research results confirming rather limited consumer skills related to the subject, efficient methods to make people increase their awareness of what correct selective waste collection is, seem to remain still undiscovered. The students' task is both to identify why mistakes in waste segregation are made, as well as to propose ways of helping citizens avoid them.
\end{abstract}

Keywords: households behaviour, selective waste collection, waste segregation rules. 


\subsection{Description of the issue}

Poland is obliged to achieve a defined reduction level in biodegradable municipal waste volume sent to landfills (by $16^{\text {th }} \mathrm{Jul}$. 2020, it was supposed to be no more than $35 \%$ ), as well as levels of recycling, preparation for re-use and recovery of paper, metals, plastics and glass by other methods (by $31^{\text {st }}$ Dec. $2020-50 \%$ ), and nonhazardous construction waste (by $31^{\text {st }}$ Dec. $2020-70 \%$ ) (Ministerstwo Klimatu i Środowiska, 2021).

The main goals of the Municipal Cleanliness Maintenance Act (Ustawa $\mathrm{z}$ dnia 13 września 1996 r.) are, above all, promoting waste segregation among citizens and reducing the volume of municipal waste deposited in landfills by providing installations dedicated to their recovery or neutralisation.

Furthermore, standards of waste container and plastic bag marking (colour of bins or bags, as well as type of fraction description) have been defined in the regulation provided by the Minister of Environment on detailed methods of different waste fraction selective collection (Rozporządzenie Ministra Środowiska z dnia 29 grudnia 2016 r.). The legal act standardises visual aspects related to basic tools for selective waste collection.

Although various legal acts regulating the issue of waste segregation have been introduced, according to research conducted by "ARC Rynek i Opinia" [Eng. ARC Market and Opinions] and "Forum Odpowiedzialnego Biznesu" [Eng. Forum for Responsible Business], only $66 \%$ of Polish citizens declare active participation in selective waste collection, which may be a consequence of their low levels of knowledge on the issue. Moreover, as mentioned above, it has been proved in research that only $15 \%$ of respondents could really properly segregate sample types of waste, and as such, rate of them correctly in response to all questions related to selective collection (into which bin one should dispose of dirty tissues, juice cartons or greasy paper from butter). Another of the discussed subjects was whether it was necessary to wash metal or plastic packaging before disposal. A high rate (75\%) of respondents was not aware that such waste should not be rinsed (Co trzeci Polak nie segreguje śmieci, 2019).

General instructions defining what should be considered as a particular type of waste (paper, glass, bio waste, metal and plastic packaging, residual/mixed waste) are the same not only in Poland, but also in many EU countries. However, they might vary in details depending on region or sometimes, even because of some specific requirements defined by a particular municipality. Therefore, it is always essential to follow instructions described by local authorities or operators providing waste collection service in a given area. Example regulations can be found on the following websites:

- Warsaw Municipality (New waste segregation rules, 2019);

- Gdańsk Municipality (I sort waste. Polish National System for Sorting Waste, 2020); 
- Nicolaus Copernicus University in Toruń (New waste segregation rules in Poland, 2020).

Although the rate of those who try to segregate waste is $66 \%$, the total percentage of people considering it as worth doing and meaningful is smaller than that (58\% of respondents). Therefore, environmental education is a crucial element in increasing people's knowledge and awareness of recycling process importance. Nevertheless, it must be stressed that, although an increase in awareness will improve the way people understand the problem, it will still require further efforts to make them change the way they really carry out selective waste collection.

\subsection{Segregation versus waste collection costs}

Inhabitants of an estate in a big city were informed that their waste collection fees would increase. As most of them had declared the will to segregate waste, which was supposed to guarantee low charges, the information surprised people and generated remarkable frustration. They were explained that while collecting waste, many fallacies in segregation were discovered, which further resulted in processing cost increases, and as a consequence, affected prices for inhabitants. The conclusion from the people's responses was that they believed they always properly disposed of all fractions (e.g. food packaging) into containers dedicated to particular types of waste. When such an explanation was passed onto the operator providing waste collection services, specialists in the enterprise started analysing different options of how to make waste segregation more comprehensible and convenient. They wanted to identify all reasons and sources of fallacies, and to introduce an action plan in order to help inhabitants follow selective waste collection rules. Although financial consequences are theoretically a good motivator, in the case of blocks of flats where many people share responsibility for following or not following certain rules, such negative motivation might not be efficient in the long-term. Therefore, education and functionality improvement seemed to be worth consideration. It was assumed that the inhabitants took efforts to pre-segregate waste in their flats and that only they had access to their waste containers. The specialists tried to identify what caused mistakes in segregation as well as if the waste was disposed while leaving home to go somewhere or if people would purposely go out to get rid of trash.

At first, the idea was to make sure that all waste segregation containers were equipped with instructions stating how they should be used. The expectation was that in time, users would perfectly recognise which colour of container should be used to dispose of each waste fraction. Then, another option was considered. Someone made the suggestion to create a new role in the organisation-in-field specialists that would make random visits to different locations at the estate to 
verify types of materials disposed into waste bins. In case of any fallacy, they would leave a note explaining the importance of recycling and waste segregation, giving reasons as to why failures in the process would increase costs of the service. There was a discussion as to whether the message should be rather educational or more alike a threat, but finally, most of the brainstorming participants agreed that positive information would most probably be followed by a positive response. Another option also considered by the specialists was to refuse to collect waste in case of fallacies discovered by waste truck crews, followed by written warnings that penalties for such behaviour may be charged in the future. Someone also suggested that an action similar to that related to the negative results of smoking cigarettes could also be considered. The idea was to show the negative influence of waste management mistakes on the environment, such as birds suffocated by plastic bags or large amounts of garbage affecting landscapes of some areas. The last suggestion was not accepted by the meeting participants, although, it seemed to be interesting.

Apart from educational aspects, functionality issues were also discussed. Someone explained that frequent cases noticed in waste container sheds were that the majority units were half empty and had closed lids, while a few ones had open lids and different types of waste protruding over their upper edge by up to 1 metre. The reason was that inhabitants throwing the garbage out on their way to visit a shop, friends, etc., would choose the nearest open bin rather than the one dedicated to a particular waste type. As the people's need to keep their hands clean is important also due to hygienic reasons, it was decided to consider equipping containers with hygienic solutions such as openings dedicated to the disposal of particular waste types into containers without the need to open them, or with foot pedals allowing to open lids without touching containers using one's hands. However, as applying such equipment to existing units would be technically challenging and rather costly, it was decided to consider such options in newly produced products to be ordered in the future.

\section{Questions / tasks}

1. Prepare a market research draft that would let you identify reasons/sources of fallacies in waste segregation.

2. What would you do to evaluate the efficiency of different motivation systems for inhabitants to encourage them to carry out proper waste segregation?

3. Those that are against technical solutions making waste segregation more convenient say that the accessories generate additional costs and metal foot pedals generate a risk of getting stolen by scrap collectors.

4. What arguments would you use against such doubts?

5. What would you do to reduce the cost of such equipment? 
6. The stakeholders in waste management processes are citizens, enterprises, municipalities and state authorities. They all declare their dedication to environmental protection and circular economy rules. What actions related to the issues are taken by each of the stakeholders properly, and what fields for improvement would you identify?

7. There are people that do not like to describe waste as "waste"-they call them "raw materials". Others focus on the limitations of recycling development due to its high cost. Which of those groups do you represent and how would you try to convince members of the other group to your arguments?

\section{References}

Bruvoll, A., \& Nyborg, K. (2002). On the value of households' recycling efforts (Discussion Papers No. 316). Statistics Norway, Research Department, 1-21.

Co trzeci Polak nie segreguje śmieci. (2019). Retrieved from https://arc.com.pl/co-trzeci-polak-nie-segreguje-smieci\%e2\%80\%a8/

Czajkowski, M., Kądziela, T., \& Hanley, N. (2012). We want to sort!-assessing households' preferences for sorting waste (Working Papers No. 7/2012 (73)). University of Warsaw: Faculty of Economic Sciences. https://doi.org/10.1016/j.reseneeco.2013.05.006

Huhtala, A. (2010). Income effects and the inconvenience of private provision of public goods for bads: The case of recycling in Finland. Ecological Economics, 69(8), 1675-1681.

I sort waste. Polish National System for Sorting Waste. (2020). Retrieved from https://czystemiasto. gdansk.pl/ZDiZGdanskFiles/file/ulotka_SS_ENG.pdf

Jenkins, R. R., Martinez, S. A., Palmer, K., \& Podolsky, M. J. (2003). The determinants of household recycling: a material-specific analysis of recycling program features and unit pricing. Journal of Environmental Economics and Management, 45, 294-318.

Ministerstwo Klimatu i Środowiska. (2020). Zasady segregowania odpadów komunalnych. Retrieved November 2, 2020 from https://www.gov.pl/web/klimat/zasady-segregowania-odpadow-komunalnych

New waste segregation rules. (2019). Retrieved November 2, 2020 from http://www.um.warszawa. $\mathrm{pl} / \mathrm{en} /$ Highlights/new-waste-segregation-rules

New waste segregation rules in Poland. (2020). Retrieved November 2, 2020 from https://www. cm.umk.pl/en/news/612-new-waste-segregation-rules-in-poland.html

Omran, A., Mahmood, A., Abdul Aziz, H., \& Robinson, G. M. (2009). Investigating households attitude toward recycling of solid waste in Malaysia: A case study. International Journal Environ. Res., 3(2), 275-288.

Rozporządzenie Ministra Środowiska z dnia 29 grudnia 2016 r. w sprawie szczegółowego sposobu selektywnego zbierania wybranych frakcji odpadów. Retrieved November 2, 2020 from http:// isap.sejm.gov.pl/isap.nsf/download.xsp/WDU20170000019/O/D20170019.pdf

Ustawa z dnia 13 września 1996 r. o utrzymaniu czystości i porządku w gminach. Retrieved from http://isap.sejm.gov.pl/isap.nsf/download.xsp/WDU19961320622/U/D19960622Lj.pdf 



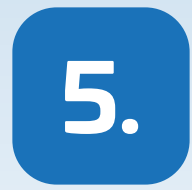

\title{
CIRCULAR ECONOMY IN THE WASTE MANAGEMENT SECTOR
}

Gabriel Grabowski

Contenur Polska Sp. z o.o.

\begin{abstract}
The growing population and rising standards of living lead to an increase of the consumption of many goods. Reducing municipal waste which is created in that process can result in a wide range of environmental, economic, and social benefits, such as reducing pollution in water and soil, greenhouse gas emissions and loss of valuable materials. The concept to solve this problem of municipal waste due to increased consumption can be found, among others, in circular economy (CE). Circular economy can be defined as "an economic system that is based on business models which replace the 'end-of-life' concept with reducing, alternatively reusing, recycling and recovering materials in production/distribution and consumption processes to accomplish sustainable development" (Kirchherr, Reike, \& Hekkert, 2017). A current trend in developed countries is closing the loop, moving from the concept of "end-of-pipe" waste management towards more holistic resource management (Wilson, 2007). Implementing the circular economy approach through waste management systems can pose multiple challenges while providing incentives to improve waste management infrastructure. However, this requires investments and may be perceived by many people as cost, not investment in future generations and their standard of living.

The aim of this chapter is to initiate discussion on the positive aspects and barriers of circular economy development in the Polish waste management sector.

In the case study described in the text, the roles of citizens, public institutions as well as enterprises are shown in selective waste collection processes as an important element of circular economy.

In Poland, awareness of waste segregation and the importance of using recycled materials is not well-developed compared to many other EU countries, although this situation is beginning to gradually improve.
\end{abstract}

Keywords: circular economy, Corporate Social Responsibility, recycled materials, selective waste collection, waste segregation. 


\subsection{Problem of communal waste segregation}

Waste management contains a multi-level system, embracing central governments for setting strategies, creating national plans, then, regional and in most cases, local authorities for designing and implementing policies and organising tools for waste collection, treatment and disposal. Factors that influence waste management in the country belong to different macro-environmental categories such as: political (political will, government taxes and subsidies), data collection and monitoring, economic (business model, cost-benefit analysis, availability of financing, collaboration and transparency along the value chain), environmental (sustainability policy, human health impact), social (community perception), technological progress (innovation, infrastructure), and educational (research centres, cooperative projects) (Malinauskaite et al., 2017). As Ribić, Voća and Ilakovac (2017) noticed, appropriate solutions for the complex waste management problems should be analysed from a systemic perspective, taking all of the above factors that are present in a local area into account.

Segregation of communal waste has been a popular issue in Poland for many years, frequently used as an argument in political debate. Some would complain of local or state authorities not being able to solve problems of odours coming from waste processing installations to people's housings. Others would notice tons of waste on the streets of many cities as a result of badly coordinated collection. Nevertheless, the most common topic of discussion on waste has always been money. One of the main challenges in introducing circular economy ideas are the costs generated by the process. On one hand, everyone would agree that it is absolutely crucial for future generations to intensify efforts in environmental protection, of which waste segregation is a part. On the other hand, politicians have made people believe that waste collection prices depend on only the decision of clerks. They frequently attack their opponents for increasing charges, trying not to notice all the costs behind the decisions, such as labour, energy, fuel, investments in technology, etc. As a result, citizens expect waste management to be cheaper and furthermore, they believe that selective collection reduces costs. That is a totally wrong assumption, as waste segregation has always required investments and the cost will keep on growing. Unfortunately, there is not much that politicians or local authorities can do to minimise the increase, except for not changing regulations too often and listening to experts before making decisions on new legal acts or requirements. Our society needs to accept the costs and treat them as investments in the future of our children. Not only citizens have to get involved in waste segregation, or politicians need to provide reasonable management of the process, but also, enterprises have to play an important role in introducing ideas of circular economy as a significant element of their Corporate Social Responsibility policies. 


\subsection{Corporate Social Responsibility challenges and recycling}

A good example of management based on the circular economy idea is the Contenur group, an international provider of container systems for the selective collection of communal waste that has 5 production centres, 2 in Getafe, Spain, 1 in Mielec, Poland, 1 in Knowsley, U.K., and the $5^{\text {th }}$ centre in Mandirituba, Brazil. The enterprise develops its promotion and service-providing activities through its own commercial subsidiaries in 14 countries and through distributors in further 41 countries. The company's mission is to design, manufacture, commercialise and maintain urban waste containers, that improve quality of live, sustainability and the appearance of towns and cities. One of the group's basic principles is to reduce the negative environmental impact of its actions by applying strict prevention and waste management policies, responsible use of materials and by establishing standardised environmental management systems for all its activities. The risks detected where environmental impact is concerned are: $\mathrm{CO}_{2}$ emissions, waste generation, waste disposal and consumption of raw materials. Fulfilment of the principle has been proved by a number of certificates: Quality Management System Certification ISO 9001:2015, Environmental Management System Certification ISO 14001:2015, Health \& Safety Management System Certification OHSAS 18001:2007, Energy Management System Certification ISO 50001:2018, Chain-of-Custody (CoC) Certification based on FSC standard, Chain-of-Custody (CoC) Certification based on the PEFC standard, Carbon Footprint Registration with the Spanish Climate Change Agency, Operation Clean Sweep ${ }^{\circledR}$ (OCS) Certification, Ecodesign Management System Certificate ISO 14006:2011. One of the key points in the enterprise's product development policy is to design products that are more and more environmentally-friendly, from the moment they are manufactured until they are made available to the customer and reused at the end of their working "life" (all components of containers can be recycled), as well as to develop products that help their customers improve their recycling rate and quality of recycled materials.

The company works on increasing the usage of recycled, high-density polyethylene in its production, which is rather unitary from a technological point of view, but requires a diversified policy to promote recycling. Although the technology of regenerated polyethylene consumption in the manufacturing process introduced in the Polish production plant established in Mielec in 2012 follows many years of experience, in the Spanish factory, the way of promoting products made of recycled material has to be different, as awareness of recycling importance in Poland is not at the same stage as in most EU countries. In many places in Europe, the usage of recycled materials in the product manufacturing process is one of the conditions 
for participation in public tenders. The Contenur group positively responds to this requirement and participates in the Circle project. This is the concept combining and defining strategy, positioning, way of acting, obligations and development in the group's environmental sustainability policy. It applies to all elements that concern recommendations made by the European Commission regarding specific subjects and activities revolving around environmental sustainability as well as recycling plastic. The enterprise is working to create strategic alliances that enable change by raising awareness in society and reducing waste generation while, at the same time, encouraging people to recycle. Simultaneously, in Poland the enterprise faces tenders organised by public institutions that exclude containers even partly made of regenerated polyethylene. The reasons for that are not quite clear but it is usually justified by the product's high-quality requirement. Of course, such a justification does not seem to be correct, as high-end products can be manufactured if proper quality-control of materials, components, the production process and final products is provided, while the composition of materials is a subject to designer's decision. It may sometimes even appear that a product made of recycled material is of better quality than that produced of virgin polyethylene, depending on how the material and component purchasing process and final product manufacturing are managed. The approach of some Polish public organisations is difficult to understand as, at the same time, they purchase tools used in the recycling process (waste segregation containers) and question the sense of using recycled materials. Such situations force the Polish branch of Contenur to officially apply for change in tender specifications. One of the arguments used in such cases is that the public institutions actually exclude socially responsible companies that have invested in modern production systems that allow usage of regenerated polyethylene. Another argument comes from Urząd Zamówień Publicznych [Eng. The Polish Public Procurement Organisation], an independent unit within the government that plays a policy-making and coordinating role in the whole public procurement system for Poland, encouraging public institutions to promote green public procurement, meant as purchasing goods and services generating less negative environmental impact in their whole "life-cycle" if they provide the same functionality as other goods or services. Although that is still a remarkable challenge for the development of circular economy in Poland-it must be mentioned that the rate of public organisations that positively respond to the requests mentioned above, and in following tenders, never forbid regenerated polyethylene increases. 


\subsection{Education and convenient selective waste collection}

Apart from providing products with "life-cycle" based on circular economy rules and offering expert advice on solutions optimal for citizens and the environment, Contenur believes that it is absolutely crucial to motivate people to actively participate in the selective waste collection process. Although penalty systems suggested by some authorities might be one of the options, the enterprise focuses on positive motivation, mainly by making waste segregation more convenient and by educating people on the importance of circular economy.

Easy access is provided when waste containers are equipped with openings dedicated to different fractions (glass, plastic and metal packaging or paper), or with foot pedals. Such solutions make users more willing to dispose of waste into bins dedicated to it rather than to just throw it into the nearest open unit, no matter its colour. Contenur has been promoting such equipment for many years by advertising and face-to-face presentations. The meaning of the possibility to keep one's clean hands while disposing waste into containers has further increased at the time of the COVID-19 pandemic. Citizens have become more aware of how important it is to use hygienic solutions, although here, the huge role of municipalities must be stressed.

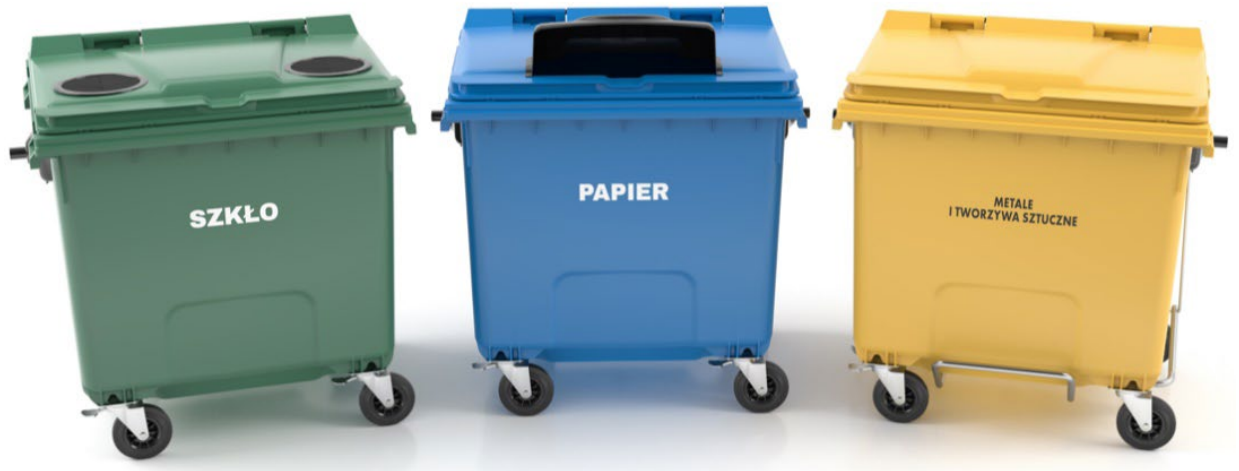

Figure 1. Waste segregation containers with glass and paper openings and with foot pedals

Source: (Contenur, 2020).

A waste collector that has to be competitive to win a public tender will never increase costs of operations by purchasing additionally equipped products at its own will. It should be the municipality that expresses expectations towards functional equipment of waste containers. However, it is important to mention that when doing 
so municipal clerks frequently make mistakes. One of them is avoiding discussion with solution providers on what options are possible. In such cases, equipment that is not available on the market frequently appears in tender specifications, which results in either lack of the possibility to obtain it, or generates enormous costs to develop special solution for 1 municipality. Another mistake is to consult the specifications with only 1 producer, which may sometimes result in remarkable limitations of the offer number, usually leading to pricing increases. The proper way to conduct the process of creating tender specification is to consult functional expectations with a number of providers and follow the advice that comes up in the majority of discussions.

Education on how to segregate waste, as an important element of circular economy, should be provided at a very early stage. Therefore, Contenur has joined the "Recycling+Education" (Rec-Edu) project initiated by Replas Recycling Plastics in Poland in 2019, in which a number of enterprises, foundations as well as municipalities take part. One of the aims is to support children and youth education about environmental protection as well as recycling. Contenur has manufactured, using regenerated polyethylene, sets of communal waste bins dedicated to the project that are being conveyed to selected educational institutions (project participants) in order to be used for education about waste segregation. Due to some delays caused by pandemic threat, the initiative is still at a rather early stage in 2021, with 10 schools in southern Poland provided with waste segregation bins, but with plans to get more educational institutions involved. Furthermore, the set of waste segregation bins dedicated to the project qualified for the $2^{\text {nd }}$ stage of the 2020 "Product in Circulation" competition, initiated by the Polish Ministry of Climate and Environment, and organised by the Poznan International Fair (MTP Group).
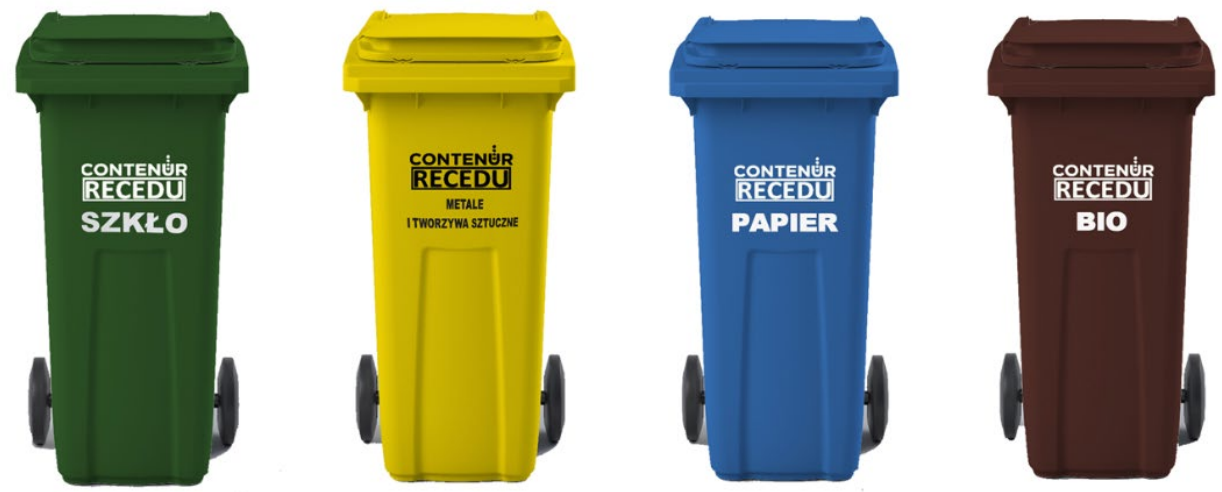

Figure 2. Set of communal waste bins dedicated to the Rec-Edu project Source: (Contenur, 2020). 


\section{Questions / tasks}

1. Why is waste management a popular issue in political debate?

2. What should politicians and local authorities do to compromise between people's current needs and protection of the environment for future generations as far as waste is considered?

3. Why are the "green regulations" related to products made of recycled materials sometimes ignored in tender specifications?

4. What kind of innovative solutions could container manufacturers implement in communication to motivate people to segregate waste properly?

5. Identify the mission and vision of the Contenur Group. What are the producer's core values? Go to its website (both the corporate and Polish one) and answer the question: How does the company implement SDGs in:
a) production;
b) logistics;
c) $\mathrm{R} \& \mathrm{D}$;
d) marketing and sales;
e) HR;
f) corporate governance

6. How would you convince B2B decision-makers to choose products made of recycled materials, and what doubts would you have to argue with

7. What actions could be taken by municipalities to motivate citizens to segregate waste properly? Is negative (penalties) or positive (education, functional solutions) motivation more efficient? How could authorities verify which solutions are efficient?

\section{References}

Contenur. (2019). Annual CSR report 2019. Retrieved October 10, 2020 from https://docs.google.com/ viewer?url=https://s3.eu-west-3.amazonaws.com/contenur.com/wp-content/uploads/2020/05/ Memoria_2020_V2_EN.pdf

Contenur. (2020). Sustainability. Retrieved from https://www.contenur.com/en/sustainability/

Contenur\&Circle. (2020). Commited to the future. Retrieved from https://docs.google.com/ viewer?url=https\%3A\%2F\%2Fs3.eu-west-3.amazonaws.com\%2Fcontenur.com\%2Fwp-content \%2Fuploads\%2F2019\%2F10\%2FCircle_Commited_to_the_future_Digital.pdf

Kirchherr, J., Reike, D., \& Hekkert, M. (2017). Conceptualizing the circular economy: An analysis of 114 definitions. Resources, Conservation \& Recycling, 127, 221-232.

Malinauskaite, J., Jouhara, H., Czajczynska, D., Stanchev, P., Katsou E., Rostkowski, P., ... Spencer, N. (2017). Municipal solid waste management and waste-to-energy in the context of a circular economy and energy recycling in Europe. Energy, 141, 2013-2044.

„REC-EDU”, czyli pomysł na czystszą planetę. (2020, November 15). Życie Podkarpackie. Retrieved from https://www.zycie.pl/informacje/artykul/29015,rec-edu-czyli-pomysl-na-czystsza-planete 


\section{5.}

Gabriel Grabowski

RePlas. (2019). Projekt „Recykling + Edukacja”. Retrieved December 13, 2020 from http://replas. $\mathrm{eu} / \mathrm{p}=1206$

Ribić, B., Voća, N., \& Ilakovac, B. (2017). Concept of sustainable waste management in the city of Zagreb: Towards the implementation of circular economy approach. Journal of the Air \& Waste Management Association, 67(2), 241-259.

Urząd Zamówień Publicznych. (2020). Zielone zamówienia. Retrieved October 10, 2020 from https:// www.uzp.gov.pl/baza-wiedzy/zrownowazone-zamowienia-publiczne/zielone-zamowienia

Wilson, D. C. (2007). Development drivers for waste management. Waste Management \& Research, 25(3), 198-207. https://doi.org/10.1177/0734242X07079149 


\title{
6.
}

\section{SUSTAINABILITY IN RENEWABLE ENERGY BUSINESSES}

Gabriel Grabowski

Contenur Polska Sp. z o.o.

\begin{abstract}
The sustainable development goal 7 (affordable and clean energy) seeks to ensure that energy is clean, affordable, available and accessible to all (SD Goals, https://unstats.un.org/sdgs/ indicators). Replacing fossil fuel-based energy sources with renewable ones, which include: bioenergy, direct solar energy, geothermal energy, hydropower, wind and ocean energy (tide and wave), would gradually help the world achieve the idea of sustainability. Renewable energy technologies provide an excellent opportunity for mitigation of greenhouse gas emission and reduce global warming through substituting conventional energy sources (Panwar, Kaushik, \& Kothari, 2011; Owusu \& Asumadu-Sarkodie, 2016). Nevertheless, investment costs, as well as political environment and market conditions, have become barriers preventing countries from full utilisation of the potential to improve the quality of air or water.

The aim of the chapter is to initiate discussion on the importance of renewable energy as well as its environmental and society-related health aspects. Two short case studies presented in the text allow to describe projects concerning solar installations. In the first case, it is educational institution investing in thermal solar panel systems to supply heat for domestic hot water. The results of research conducted by Filho et al. (2019) on a small sample of universities from around the world indicate that in more than half of them, only a small share of energy consumption comes from renewable sources, whilst the European Union policy has identified promotion of energy efficiency in buildings, including educational ones, as a key objective of its energy and climate policy (EPBD Recast, 2010). In the second case study, thoughts on photovoltaic systems installed to supply buildings with electricity are contained and the problem of public resource support forms for that purpose are discussed.
\end{abstract}

Keywords: renewable energy sources, solar energy. 


\subsection{Introduction: green energy}

Development of renewable energy sources has been supported by many governments for years, both in large scale projects (such as wind farms) as well as by motivating citizens to invest in green energy for their houses (solar thermal panels, heat pumps and photovoltaic systems). Poland was not a leader of the process, which was probably caused by many factors, however, the tradition of coal mining seems to be an important one. Renewable energy enthusiasts waited years for state regulations supporting such solutions, and when they finally came, they did not seem to be as motivating as what was previously introduced in some western countries (e.g. Germany, France).

Apart from the pressure of such stakeholders as the mining industry, renewable energy development was also affected by those who would use every occasion to prove that it did not pay off. Of course, in many cases, direct comparison of investment costs and future financial savings would confirm such theses. Nevertheless, governments should always take environmental and health aspects of such projects into consideration. Environmental pollution and, as a consequence, deterioration of society's health, generates remarkable financial costs, which has also been confirmed by Harry Wirth from Fraunhofer ISE (Fraunhofer ISE, 2021). Every year in Poland, from 45,000 to 48,000 people die because of air pollution (smog). The problem of premature death because of air quality touches 400,000 Europeans (PolsatNews, 2018). On the other hand, from a Corporate Social Responsibility point of view, it must be stressed that the positive effect of renewable energy sources will be high if equipment dedicated to such systems is environmental-friendly at all stages of the products' "life": from manufacturing, throughout transportation, installation and operation, to the moment when they need to be recycled.

\subsection{Thermal solar installation at educational institutions}

A thermal solar installation expert was asked to consult a project regarding a rather large system for domestic hot water purposes at an educational institution. When he met the engineer responsible for managing the project (and was also a representative of the investor), he started to have doubts whether total surface of the solar panels was appropriate for the needs of the building that was supposed to be equipped with the system. The only activity at the facility were classes with students, which actually meant that domestic hot water would be used only to wash hands (no baths or showers). A response to the question as to why such a size of the instal- 
lation had been planned surprised the consultant, as it became clear that the only determinant was the minimal surface that could obtain subsidy. He asked if the subsidy was supposed to cover $100 \%$ of investment cost. When that the answer was it would only be partial, he advised the engineer to make a new plan with reduced budget-equal to financing part that the investor would have to cover anyway. In this way, the solar panels would achieve the same cost, but in addition, they would also get a chance to function properly whilst the oversized installation with subsidy would immediately go into breakdown mode due to a heat supply much higher than the demand. The consultant never received feedback as to whether his advice was followed. Nevertheless, it was rather surprising that neither the environmental effects nor future cost savings were initially determinants for those planning the investment. Even the cost for the investor was not an issue. The only factor taken into consideration was how much money could be provided by a $3^{\text {rd }}$-party-no matter if it was needed or not. To respond to any doubts that might occur-heat transmission from one building to another is usually technically-challenging and cost-consuming. Therefore, covering the energy supply by demand from another facility, would not be an efficient solution.

\subsection{Development of photovoltaic installation}

A private, Polish investor decided to have his house equipped with a photovoltaic installation (Figure 1) to cover his electrical energy consumption that was high as-apart from lighting and standard electrical home appliances-the facility was heated by a heat pump system-much more efficient than direct electrical heating (e.g. radiators or storage heaters), but still consuming a remarkable amount of electricity. The company that prepared the offer for the investor provided him with potential savings calculations, that compared to investment cost (decreased by a small subsidy and some tax reduction), meant pay off in ca. 10 years. As the guarantee period for PV panels was 20 years (which suggested their working "life" length), it could be questioned if it was worth getting the system. One of the reasons why the payback period was rather long was the fact that power company supplying the building with electricity would charge $20 \%$ of energy that would go to its network (in the periods when photovoltaic supply was higher than the household's demand) - the investor would only get $80 \%$ of his electricity production back free-of-charge. It is obvious that if the electricity provider charged $20 \%$, it was allowed by certain regulations. However, this is an interesting subject for discussion on the responsibility for future generations and the environment they will inherit from today's generations-if it should be allowed to set such high charges for those who had decided to invest in green energy with a little support 
of subsidies and tax reduction (in this case, the estimated financial support was, in total, less than $40 \%$ of the investment cost). A positive example of different regulations could be the German Renewable Energy Act introduced in 2000 that guaranteed fixed feed-in tariffs for renewable energy generation (a policy mechanism providing remuneration above the retail or wholesale rates of electricity), which encouraged households' owners to install solar panels for their own consumption or feeding the electricity produced into the grid. The solution engaged citizens and communities in the process, and in 2012, close to half of the renewable energy capacity in Germany was owned by individuals or by local as well as regional energy cooperatives, having contributed almost $1 / 3$ of total investments to the renewable energy generation (European Commission, 2018). The investor mentioned before, finally decided to get photovoltaics installed, as he estimated that the majority of his energy consumption would be covered by renewable sources (PV installation and heat pump), which generated some satisfaction.

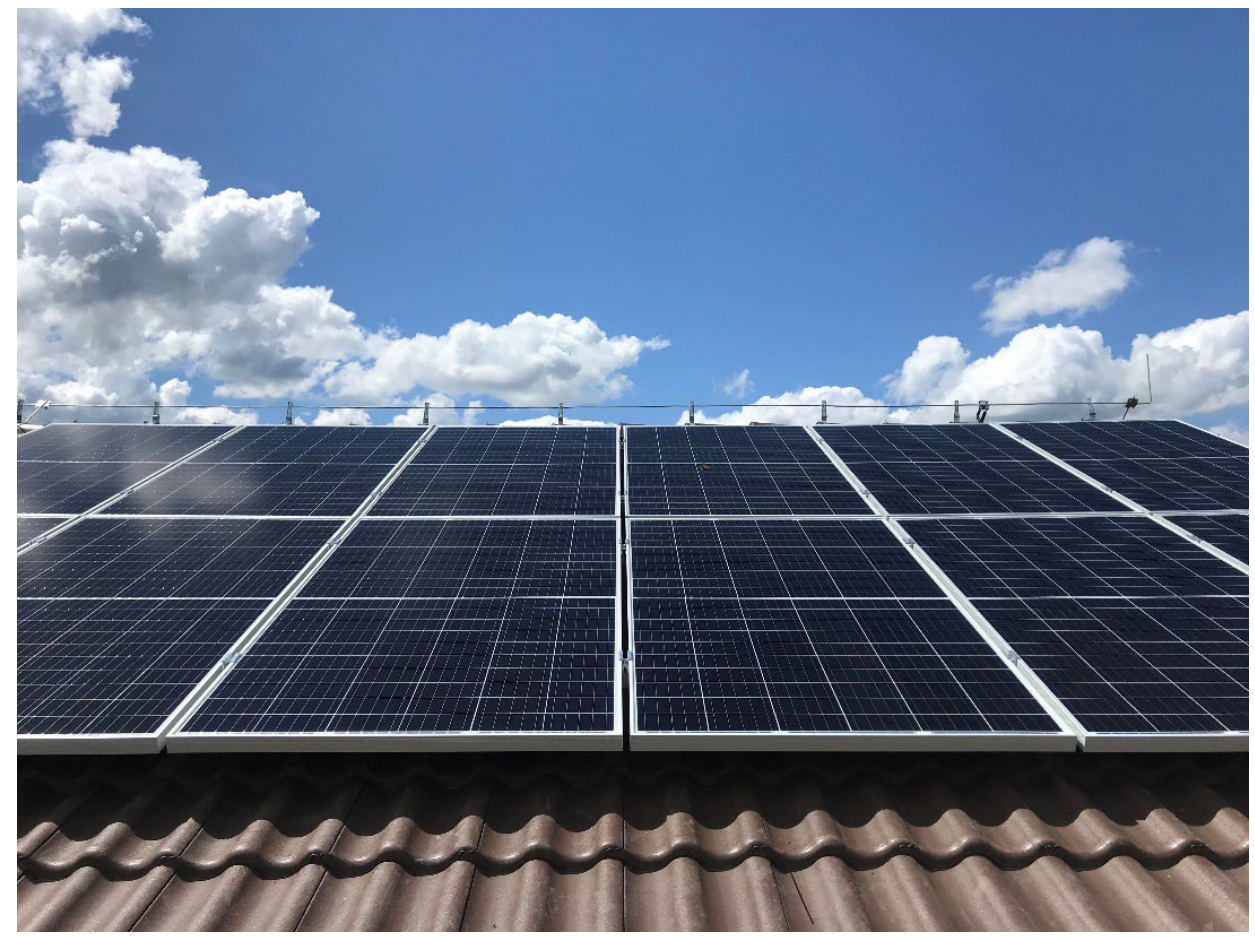

Figure 1. Photovoltaic installation

Source: Author's archives. 


\section{Questions / tasks}

1. Taking into consideration the fact that small photovoltaic installations in private households mean not only better quality of air in the neighbourhood or money saving for their owners, but that they also make electricity production more diversified on a larger scale-do you think that charging $20 \%$ for the energy supplied to the network is appropriate?

2. How can universities promote sustainable energy?

3. Many countries subsidise green energy. Do you think that the "green" subsidies in your country are sufficient? Compare solutions implemented in at least 2 countries (visit websites). What kind of determinants are behind solutions implemented in those countries? Classify them and explain. Are those solutions really effective or just a kind of compromise? Discuss the issue.

4. How should efforts to leave a clean environment for future generations and care for today's workers in the coal industry be balanced in countries with a long tradition of mining?

5. How does energy from renewable sources influence the health of society and overall quality of life? Justify your opinion.

6. Socially responsible enterprises try to consider whether renewable energy equipment is environmental-friendly at all stages of product "life": from manufacturing, throughout transportation, installation and operation, to the moment when they need to be recycled. They often do not have the tools needed to influence suppliers, especially if rare raw materials or components are required. However, they promote their products as sustainable. What do you think about such an interpretation?

\section{References}

EPBD Recast. (2010). Directive 2010/31/EU of the European Parliament and of the Council of 19 May 2010 on the energy performance of buildings (recast), in Official Journal of the European Union, L153/13-153/35. Retrieved January 10, 2020 from https://eur-lex.europa.eu/LexUriServ/ LexUriServ.do?uri=OJ:L:2010:153:0013:0035:en:PDF

European Commission. (2018). Energiewende. Case study report. Retrieved from https://ec.europa.eu/ info/sites/info/files/mission_oriented_r_and_i_policies_case_study_report_energiewende-de.pdf

Filho, W. L., Salvia, A. L., do Paço, A., Anholon, R., Gonçalves Quelhas, O. L., Rampasso, I. S., ... Brandli, L. (2019). A comparative study of approaches towards energy efficiency and renewable energy use at higher education institutions. Journal of Cleaner Production, 237. https://doi. org/10.1016/j.jclepro.2019.117728

Fraunhofer ISE. (2021). Recent facts about photovoltaics in Germany. Retrieved from https://www. ise.fraunhofer.de/content/dam/ise/en/documents/publications/studies/recent-facts-about-photovoltaics-in-germany.pdf). 
Global indicator framework for the Sustainable Development Goals and targets of the 2030 Agenda for Sustainable Development. (2020). Retrieved October 11, 2020 from https://unstats.un.org/ sdgs/indicators/Global\%20Indicator\%20Framework\%20after\%202020\%20review_Eng.pdf

Owusu, P. A., \& Asumadu-Sarkodie, S. (2016). A review of renewable energy sources, sustainability issues and climate change mitigation. Cogent Engineering, 3(1). https://doi.org/10.1080/233119 16.2016 .1167990

Panwar, N., Kaushik, S., \& Kothari, S. (2011). Role of renewable energy sources in environmental protection: A review. Renewable and Sustainable Energy Reviews, 15, 1513-1524. https://doi. org/10.1016/j.rser.2010.11.037

PolsatNews (2018, April 11). 45 tys. osób umiera w Polsce rocznie z powodu smogu. To 12 proc. wszystkich zgonów. Retrieved January 17, 2021 from https://www.polsatnews.pl/wiadomosc/2018-04-11/45-tys-osob-umiera-w-polsce-rocznie-z-powodu-smogu-to-12-proc-wszystkich-zgonow/ 


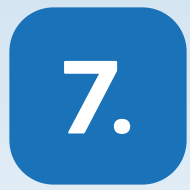

\title{
LIGHTS AND SHADOWS OF AIRBNB AND ALL-INCLUSIVE VACATIONS: HOW TO MAKE THEM MORE SUSTAINABLE?-TOURIST SECTOR
}

\author{
Magdalena Stefańska \\ Poznań University of Economics and Business \\ Iwona Olejnik \\ Poznań University of Economics and Business
}

\begin{abstract}
One of the sustainable goals refers to the tourism services sector-by 2030, devise and implement policies to promote sustainable tourism that creates jobs and promotes local culture as well as products. Responsible tourism (RT) means to:

- minimise the negative impact on the economic, environmental and social sphere (3P model);

- generate greater economic benefits for local communities;

- support the welfare of host communities;

- improve working conditions and access to the tourism industry;

- engage local residents in making decisions that will have influence on their lives, surroundings and possibilities;

- support the preservation of heritage in the sphere of nature and culture for maintaining diversity;

- provide tourists with new experiences through closer and more meaningful contact with local culture and people.

Below, of the following forms of tourist services are discussed-all-inclusive vacations and Airbnb. The goal is to invite readers to take part in the discussion on those popular forms of spending leisure time-how to make them-if possible-more sustainable.
\end{abstract}

Keywords: Airbnb, all-inclusive vacations, sustainability, tourist sector. 


\section{7.}

\subsection{Sustainability in the tourism sector}

Contemporary tourism poses a significant threat to the natural environment. One of the main reasons for the emergence of these threats are, among others, lack of tourism culture, excessive concentration of tourism in some regions and the related tourist base, bad forms of organising recreation. On the one hand, crowds of tourists visiting natural and cultural attractions, while on the other, tourist enterprises focused on short-term economic profits, in many cases, contribute to the destruction of these attractions. Increased awareness of this fact add to introducing the concept of sustainable development in tourism. Sustainable tourism is defined as: "tourism that takes full account of its current and future economic, social and environmental impacts, addressing the needs of visitors, the industry, the environment and host communities" (WTO, 2005).

\section{Five key pillars of sustainable tourism}

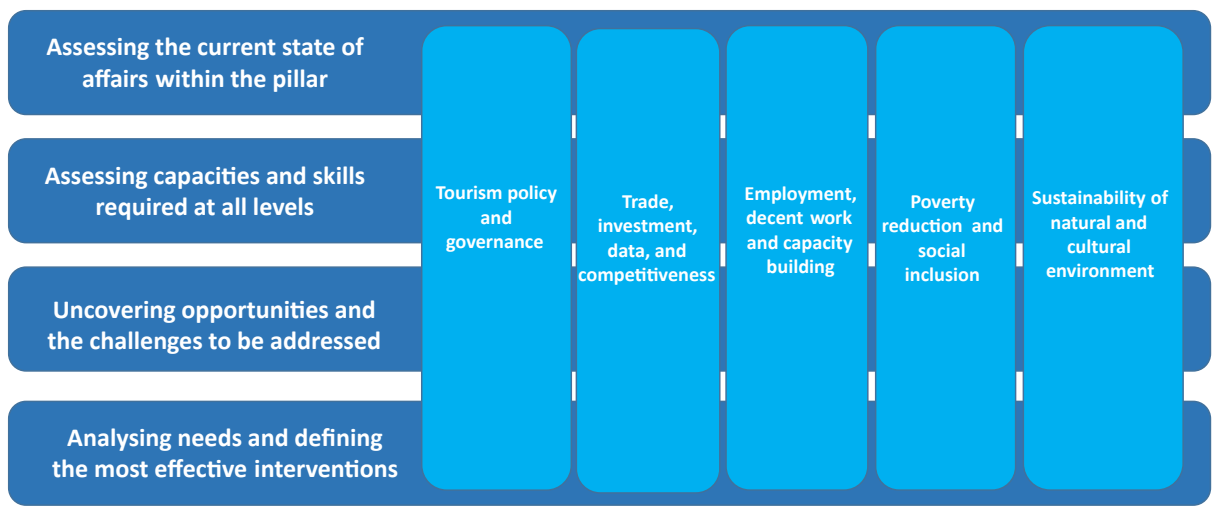

Figure 1. Five key pillars of sustainable tourism

Source: (WTO, 2005).

In the report of the World Tourism Organization (UNWTO) and United Nations Global Compact Network Spain: The tourism sector and the Sustainable Development Goals. Responsible tourism, a global commitment (2016), the following potential challenges in the tourism sector can be found and classified into priority areas: employment, environment, sustainable production and consumption, partnerships, transparency, sustainable and smart cities, as well as supply chain.

Sustainability can be managed at various levels (APEC, 2013): national, regional, local. For example, the national level is "considered as the highest extent 
for sustainable tourism in a given economy. There are policies and/or initiatives involving the whole territory and establishing sustainability in all industry levels". In contrast, at the most popular tourist sites (protected areas, historical monuments, beaches, areas of special interest), sustainable practices can play an important role in site control, management and future development of tourist attractions. Moreover, a very important level of sustainable management is that of tourism companies (hotels, tour operators, the entire transport or catering sectors). They decide whether or not to follow sustainable principles in their strategy.

The tourism sector is one of those areas of activity in which the problem of sustainable development is understood and implemented in practice in a variety of ways.

\section{Questions / tasks}

1. Five key pillars of sustainable tourism-provide examples in each area for the chosen country.

2. Find examples of good practices that companies in the tourism sector are already working on to achieve Sustainable Development Goals.

3. Overtourism is one of the negative phenomenon in contemporary tourism. Give examples of cities where overtourism occurs and ways to reduce it.

\subsection{All-inclusive as a/an (un)sustainable model of business}

All-inclusive (AI), as a form of spending vacations, was launched in the mid-20 th century in France, and in recent decades, has become popular all over the world (some sources mentioned that it origins from Great Britain and was launched in the $30 \mathrm{~s}$ of $20^{\text {th }}$ century). It relies on the idea that customers pay a one-time fee per a package of tourist services-that usually includes: lodging, a few meals daily, most soft drinks, access to the majority of services offered at a hotel (spa, swimming pool, sauna, gym) and to entertainment programmes (Figure 2). Some extra services can be charged separately, such as stronger imported alcoholic drinks, fresh-squeezed orange juice, extra menu for dinner or some additional sight-seeing trips. Services of that type are usually delivered by travel agents, such as tour operators, who organise the "vacation service pack". Then, the price often also includes travelling costs (direct transport to destination location) and insurance (sometimes optionally). This form of spending leisure time is popular among consumers who search for convenience. Also, those customers do not want to be charged for every unexpected service, thus, they prefer buying a service package prepared professionally. They want to feel safe 
and are ready to pay for that (Tavares \& Kozak, 2015; Abdool \& Carey, 2004). The language barrier is non-existent, because the tour operator delegates employees to be accessible in hosting hotel-a representative resident-she/he being a contact person, who solves travellers' problems locally and supports them if necessary. As a result, customers can fully relax. They are released from organising anything because everything is prepared by and available it a hotel. Consequently, visitors do not feel the need to leave the hotel-all their needs are satisfied in one place.

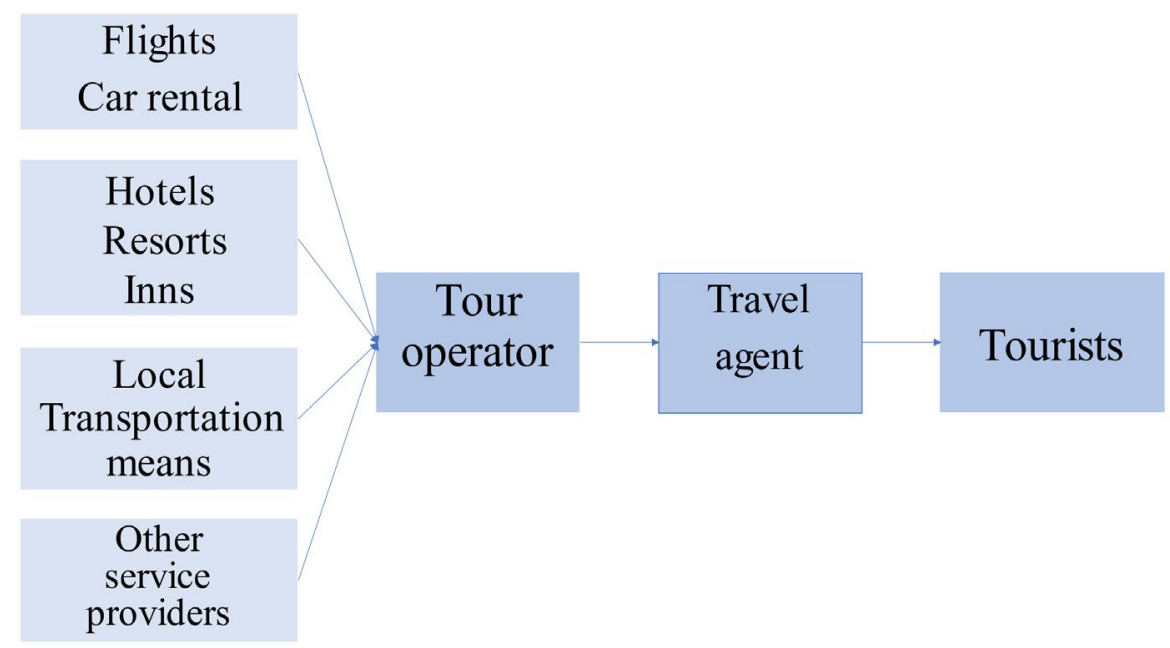

Figure 2. All-inclusive model

Source: Own work.

To make that business model profitable, a tourist agent who represents a tour operator buys a package of services from airlines (charter flights) as well as hotels, and also additional services from local service providers (e.g. bus transportation from the airport to the hotel) to add value for customers. Due to the scale of operations-the tour operator receives discounts and pays service providers much below regular price. On the other hand-hotels minimalise the risk of their business-this cooperation with tour operators lets them extend the occupancy rate, while marketing and sales costs are the responsibility of the agent or tour operator. This cooperation also leads to prolonging the tourist season by about 15-30 days. Local transportation companies also have reservations for the services they provide. As a result, the tour operator delivers customer value which was not possible to achieve alone by individual companies operating in tourist destinations and offering single, specialised services-mainly due to higher costs and lack of experience in operating abroad. 
This business model is very popular in many countries known as the most popular vacation destinations for European tourists, such as: Turkey, the Caribbean Islands, Mexico, Greece, Croatia, Italy or Spain-destinations gladly visited and attractive for vacationing.

This model of business brings positive aspects to local economy, society and customers by:

- creating work places (at hotels, restaurants, in transportation, local food production, souvenir-sellers, supporting services-for example, laundry services);

- developing local transportation means;

- forcing local governments to improve the quality of infrastructure to destination places;

- increasing standard of living for local residents;

- potentially bringing taxes to local budgets;

- promoting the region abroad, owing to relations with international travel agencies;

- saving time and money by tourists when planning a trip (owing to tour operators);

- ensuring safety-both for tourists, but also for business due to assured occupancy;

- transferring knowledge and know-how to less developed countries. On the other hand:

- some local businesses suffer because visitors are not going outside the resort-to buy in local stores or other local services-venues, car rental, parks, museums;

- tourists know little about the place they visit-they do have contact with real local culture, cuisine or community;

- every day, tourists receive the same standardised offer-they do not have many experiences with locals;

- local community loses access to local attractions like beaches or areas, which are limited for foreign tourists;

- only part of the local community benefits from such resorts-often, only in form of employment;

- AI enclaves create an economic situation in which the lower-classes are exploited as a source of cheap labour, while the foreign companies reap most of the economic benefits;

- waste, water pollution, use of energy-if they do not come from renewable resources, may have detrimental effects on the natural environment;

- natural environment may be badly hurt due the adaptation of local nature to convenience of the business, which may lead to destroying forests and natural beaches. 
Some researchers also mention (Moneim, Gad, \& Hassan, 2019):

- that hotels applying this system are likely to reduce their service quality level to increase profitability-they sell their services to tour operators with ahigh discount;

- that the system may give rise to unfair competition and as a result, the preference for the hotels that care for quality could be reduced;

- in most of the accommodation hotels, staff can be easily exploited and overworked which, as a result the, may cause the staff to treat the guests badly, finding fault in them for the low salary and difficult working conditions.

Although the meaning of all-inclusive as a form of vacations is growing, in parallel, other forms of tourism are being developed. Some of the weaknesses of AI can be overcome by other forms of spending vacations abroad, for example, by Airbnb (see chapter 7.3).

\section{Questions / tasks}

1. What would make all-inclusive vacations more sustainable?

2. Should governments set up special regulations and limitations for all-inclusive resorts to protect the local economy and environment?

3. What is given to all-inclusive tourists that is not provided by individuallyorganised vacations?

4. There is a question as to whether all-inclusive vacations, which now seem to be the least sustainable, can be more sustainable than other forms of tourism in the future. What kind of conditions would they have to fulfill? Knowing the threats and weaknesses of all-inclusive vacations from the text above-how can they be overcome? To learn more, go to the website: https:/edition.cnn.com/ travel/article/all-inclusive-resorts-sustainable-travel/index.html.

5. If you were asked to describe a tourist who chooses all-inclusive or individually organised vacations - who it would be? Create a persona using the design thinking technique.

\subsection{Airbnb as an example of sharing economy}

The activities of the Airbnb portal - an entity offering accommodation serviceswere presented. An important premise for the selection of this entity is the question whether Airbnb actually provides services on the basis of sharing economy and whether this activity complies with the principles of sustainable development. Thus, in the first part, basic information is presented with regard to sustainable develop- 
ment in tourism, the next-selected areas of the sharing economy on the market of tourism services, and the finally-the assumptions of Airbnb.

One of the examples of implementing the sustainable development concept, especially at a local level, is the dynamically developing concept of sharing economy. It allows, for example, in the area of accommodation services, apartment owners to obtain additional income, and tourists-to avoid excessive expenditure on goods and services, contributing to the effective use of their resources.

The growing popularity of the idea of sharing economy in tourism is also strongly correlated with the development of meal-sharing. Very often, making accommodation available to tourists is also associated with offering local cuisine. The Food and beverage services offered by residents (e.g. eatwith.com) allow interaction between residents providing food services in their homes and tourists. This permits both-residents and tourists-to gain valuable experience.

Another example of the sharing economy in tourism is ride-sharing. This is an alternative mode of passenger transport in which car owners offer transport to other people. In tourism, it is associated with long-distance transport (a short-distance example in this respect is, for example, Uber). It is therefore an alternative to rail and coach journeys (e.g. carpooling.com, BlaBlaCar).

Among other services offered within the sharing economy, it is worth mentioning guide and pilot services, provided by committed residents of interesting tourist destinations in various parts of the world. Often, the guides are elderly, retired persons who, therefore, can earn some extra money for their retirement through voluntary donations of tourists participating in such a $2-3$ hour walk around the city with one of its residents (e.g. travel4real).

The sharing economy concept is developing very dynamically in the tourism sector, which may contribute to the effective use of resources. Generally speaking, in the market of accommodation services, 2 basic models of the sharing economy concept can be distinguished (Stephany, 2015):

- exchange of houses and flats between service participants (e.g. HomeExchange, Knok, Love Home Swap);

- short-term rental-rental of houses, flats or rooms to interested persons by their owners, using platforms such as Airbnb, HomeAway, Roomorama, Onefinestay, HouseTrip.

Airbnb is one of the platforms enabling the provision and use of accommodation services (rental of an apartment, room, suite), which are an alternative to traditional hotel services. It is a website established in 2008 in San Francisco, California, U.S. Its founders are Joe Gebbia, Brian Chesky and Nathan Blecharczyk. The idea of this platform was born when its creators, due to the excessive maintenance costs of their rented apartment, decided to let accommodation to participants of a conference, which was soon to be held. Therefore, they placed an advertisement 
on the Internet and easily obtained additional money for renting. The company Airbedandbreakfast.com, which they founded, created a website that brokered the transactions of 21,000 customers the following year, and in 2015, it was already 40 million. "Airbnb is a provider of a vacation rental online marketplace. The company offers a website and mobile app that enables travelers to search for and book vacation home rentals and travel experiences for solo journeys, family vacations, and business trips, as well as to add events to their itinerary, message hosts, and get directions. Its solution allows hosts to share their extra space or lead experiences, update their listing and calendar availability, prepare a host guidebook, message guests, and manage reservations" (Airbnb, 2020).

Among the advantages of this form of service, it is worth mentioning the possibility of booking accommodation at the last minute and lower prices than in hotels. It is also an interesting alternative to traditional hospitality services, taking into account the potential ethnographic nature of the experience associated with it, the specificity (uniqueness) of the place of accommodation, etc. Of course, it is also a good alternative for the tourist development of those places where traditional accommodation is lacking (Airbnb, 2019).

On the other hand, the disadvantage of this solution in some countries is the possibility of renting housing to tourists via this platform, but without registration and thus, without paying taxes. Obviously, this causes dissatisfaction with those companies (e.g. hotels) that are obliged to pay such taxes, as well as those that supervise the apartment rental market. Moreover, short-term rental may cause an increase in rents in long-term rental and affect the shortage of residential premises, especially in city centres. Residents of popular cities from Barcelona to Lisbon report that they are being pushed out of their homes as developers buy properties to rent on Airbnb (Buckley, 2019). This type of service may sometimes also be treated as a competition that threatens traditionally provided accommodation services. However, there are examples of studies conducted in South Africa in which it is shown that Airbnb generally plays a largely complementary role rather than of diversionary (Mhlanga, 2020). At the same time, there are studies (in Greece) in which it is pointed out that Airbnb has turned into a significant competitor for hotels. It is primarily non-business and low-price hotels that are being influenced (Apergis, Hayat, \& Saeed, 2020).

It is worth adding that Vrumi works on a very similar basis to Airbnb. Vrumi was launched in London in 2014. It is a "sharing economy online property marketplace connecting workers and professionals needing space with householders who have rooms available in the daytime" (Cameron, n.d.). It is a website where people can book desk-space at a stranger's apartment or home. It solves the problem for selfemployed, micro-workers and other professionals (e.g. freelance web developers, writers, yoga instructors, therapists, other nomadic members) to find spaces to 
work, in areas they could not previously afford, and may not need full-time. For householders, Vrumi provides an additional source of income from rooms 'sitting' idle during the day, such as sitting rooms and dining areas (Cameron, n.d.). The typical hosts in Vrumi are:

- people out at work during the day;

- people with adult children who have left home;

- families with children at school during the day;

- semi-private space owners, e.g. rooms above shops and pubs;

- $\mathrm{B} \& \mathrm{~B}$ hosts who like renting out space during the day, or during the off-peak travelling season.

\section{Questions / tasks}

1. Sharing economy-give examples of actions that are consistent and inconsistent with the idea of sustainable development.

2. Is Airbnb sustainable? Discuss this issue.

3. All-inclusive services vs. Airbnb-indicate the pros and cons for:

- the national and local economy;

- local communities;

- consumers;

- the natural environment.

4. Find an Airbnb offer of the selected host and rate it in terms of sustainable development.

5. Startup Vrumi.com - what do you think about the idea sharing a flat for workspace? Give the pros and cons for the economy and hosts.

6. Analyse the core set of indicators for sustainability in tourism from the appendix;

- Find data for 1 city/region and compare how the tourism sector changed in time (use the scope of 10 or 20 years to analyse the change). Make some conclusions.

- Find data for 2 cities or regions and compare them. Make some conclusions.

\section{References}

Abdool, A. \& Carey, B. (2004). Making all-inclusive more inclusive: A research project on the economic impact of the all-inclusive hotel sector in Tobago for the travel foundation. Retrieved from https:// studylib.net/doc/7884050/the-economic-impact-of-all-inclusives-in-tobago

Airbnb (2019). White paper on new sustainable tourism destinations. Report November. Retrieved from https://news.airbnb.com/wp-content/uploads/sites/4/2020/02/Airbnb_WhiteBookSustainableDestinations_EN.pdf 
Airbnb (2020, October 27). [Corporate website]. Retrieved from https://craft.co/airbnb

APEC (2013). Sustainable development of tourism destinations. Tourism Leisure\&Sports. Retrieved October 3, 2020 from file://C:/Users/user/Downloads/APEC\%20Sustainable\%20Development\%20 Tourism\%20Destinations.pdf

Apergis, N., Hayat, T., \& Saeed, T. (2020). Airbnb and hotel revenues in popular Greek destinations. Journal of Economic Studies, 48(4). https://doi.org/10.1108/JES-11-2019-0512

Buckley, J. (2019). The future of sustainable tourism may lie with all-inclusive resorts. Retrieved October 3, 2020 from https://edition.cnn.com/travel/article/all-inclusive-resorts-sustainable-travel/ index.html

Cameron, A. (n.d.). Interview with Vrumi: The airbnb for workspace. Retrieved October 3, 2020 from https://www.businesscomparison.com/uk/blog/interview-with-vrumi-the-airbnb-for-workspace/

Mhlanga, O. (2020). Airbnb and hotels: friends, enemies or frenemies? International Journal of Culture, Tourism and Hospitality Research, 15(2). https://doi.org/10.1108/IJCTHR-02-2020-0051

Moneim, A. H. A., Gad, H. E. S., \& Hassan, M. S. (2019). The impact of all-inclusive system on hotels profits: An applied study to five-star hotels in Hurghada City. International Journal of Heritage, Tourism and Hospitality, 13(1), 219-240.

Stephany, A. (2015). The business of sharing, making it in the new sharing economy. Palgrave Macmillan UK.

Tavares, J. M., \& Kozak, M. (2015). Tourists' preferences for the all-inclusive system and its impacts on the local economy. European Journal of Tourism, Hospitality and Recreation, 6(2), 7-23.

WTO. (2005). Making tourism more sustainable-A guide for policy makers. Retrieved form https:// www.unwto.org/EU-guidebook-on-sustainable-tourism-for-development

\section{Appendix}

Below, you will find a core set of indicators in the area of tourism sustainable development for the EU countries: (https:/ec.europa.eu/eurostat/documents/3888793/5834249/KS-DE-06-002-EN.PDF/178f8c9a-4a03-409c-b020$70 \mathrm{ff} 7 \mathrm{ef} 6803 \mathrm{a})$. This core set forms a base of indicators that can be used on national, regional and local levels in the EU countries:

\section{Driving forces}

1. Number of beds in hotels and similar establishments

2. Number of trips by means of transport

3. Tourism-related employment (\% of total empl.)

4. Household consumption expenditure on tourism

5. Tourism share of GDP

\section{Pressure}

6. Number of tourist overnight stays in various types of accommodation

7. CO2-emissions from energy use in tourism facilities

8. Water use by tourists, per person and day, in relation to use by residential population 


\section{7.}

9. Generation of municipal waste by tourists

10. Discharge of sewage water due to tourism

\section{State}

11. Areas used for specific leisure activities, e.g.: marinas, golf courses, ski areas, etc., time series

12. Areas covered by forest and other woodland areas (\%), time series

13. Protected land and water areas (\% of land area in tourist regions), time series

\section{Impact}

14. Tourists exposed to noise at hotels and similar establishments

15. Bathing water quality, time series

\section{Response}

16. Sewage water treatment plants-volumes of treated water-time series

17. Percentage of tourist business establishments participating in recognised environmental schemes

18. Expenditure to maintain/restore cultural and historical heritage

19. Eco-labelled tourism facilities (as \% of total)

20. Existence of land use or development planning processes, specifically referring to tourism activities 


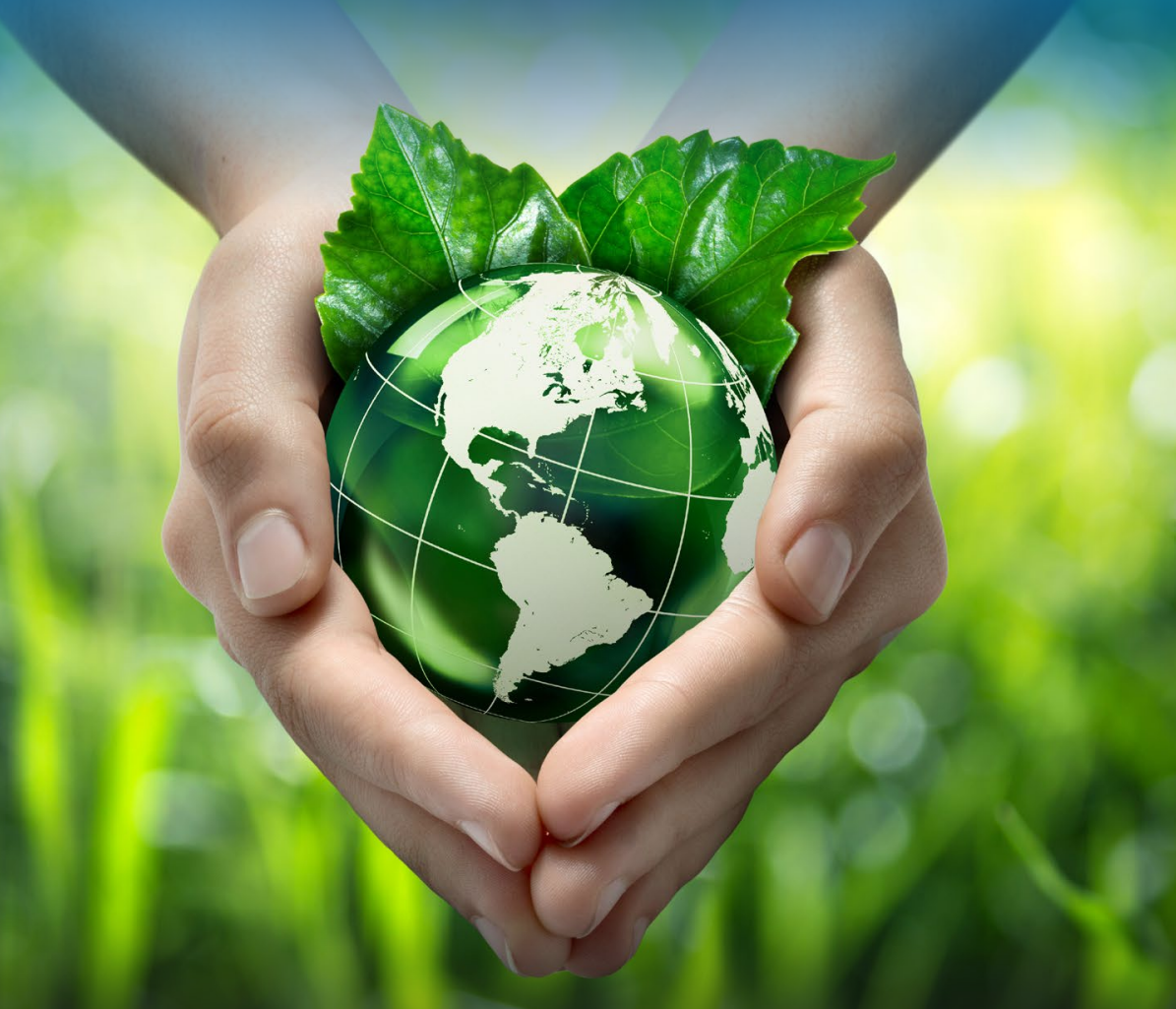

elSBN: 978-83-8211-074-6 